The author discusses signal events, not so much from the standpoint of the individual structures which were discovered from time to time during the renaissance of anatomy, but in terms of its drama and struggle to maintain its place in the hierarchy of subjects taught in medical schools.

\section{A. M. LASSEK M.D., Ph.D.}

Department of Anatomy

Boston University

School of Medicine Boston, Massachusetts

\title{
HUMAN DISSECTION
}

\section{Its Drama and Struggle}

THE STORY OF

TWO GREAT

OPPOSING AND

DIVIDED, HUMAN

FORCES, - -

neither of which has

been able to win a

total victory.
B rings the great mass of knowledge regarding the role of human dissection in the medical profession into a coherent, historical perspective.

Much of it revolves around the procurement of cadavers, a problem which is universally becoming more and more acute.

CHARLES C THOMAS • PUBLISHER Springfield, Illinois 
THE CONTENTS, in brief:

- Primitive concepts regarding the dead.

- Concepts regarding dead among ancient civilizations - 3000 to 1000 B. C.

- Pre-Alexandrian a natomy 1000 to $300 \mathrm{~B}$. C.

- The Alexandrian school of anatomy - 332 B. C. to A. D. 200.

- Claudius Galen (A. D. 130-200) and his influence on anatomy.

- Anatomy in the middle ages A. D. $400-1400$.

- Anatomy during the European Renaissance - A. D. 1350 to 1650 .

- Andreas Vesalius - A. D. 1514 to 1564 .

- Dissection on the European Continent and in Asiatic countries during the modern period - A. D. 1650 to 1958 . 
50 

From the collection of the

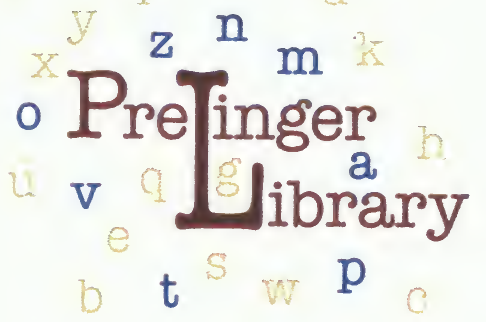

San Francisco, California 2008 



\section{HUMAN DISSECTION}

\section{ITS DRAMA AND STRUGGLE}





\section{HUMAN}

\section{DISSECTION}

\section{ITS DRAMA AND STRUGGLE}

\section{by}

A. M. LASSEK, M.D., Ph.D. ,

Department of Anatomy

Boston University School of Medicine

Boston, Massachusetts

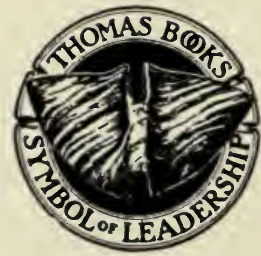

CHARLES C THOMAS - PUBLISHER

Springfield - Illinois - U.S.A. 


\section{CHARLES C THOMAS - PUBLISHER}

BanNerstone House

301-327 East Lawrence Avenue, Springfield, Illinois, U.S.A.

Published simultaneously in the British Commonwealth of Nations by BLACKWELL SCIENTIFIC PUBLICATIONS, LTD., OXFORD, ENGLAND

\section{Published simultaneously in Canada by THE RYERSON PRESS, TORONTO}

This book is protected by copyright. No part of it may be reproduced in any manner without written permission from the publisher.

\section{Copyright 1958, by CHARLES C THOMAS - PUBLISHER}

Library of Congress Catalog Card Number: 58-8425 


\section{ACKNOWLEDGMENTS}

I am especially indebted to Miss Sara Louise Emery, my research assistant, who has been associated with me in every phase of the development of the book: checking the literature, abstracting, correcting mistakes and proofreading. Her many suggestions have been pertinent and invaluable throughout.

My secretary, Miss Eileen Barbara Grossman, has also been of considerable help, not only in the typing, but in locating errors and improving the diction. 



\section{CONTENTS}

Acknowledgments .................... $\quad \mathbf{v}$

Chapter

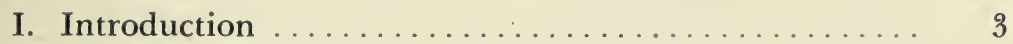

II. Primitive Concepts Regarding the Dead......... 9

III. Concepts Regarding Dead Among Ancient Civilizations -3000 to 1000 B.C.............. 20

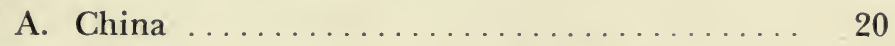

B. Japan ..................... 22

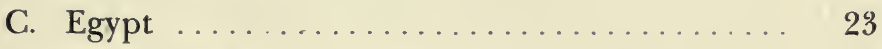

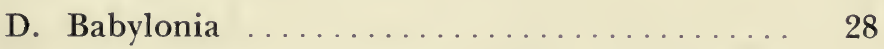

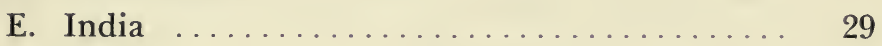

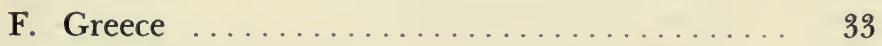

G. The Romans ................... 36

IV. Pre-Alexandrian Anatomy-1000 to 300 B.C....... 38

V. The Alexandrian School of Anatomy-332 B.C. to A.D.

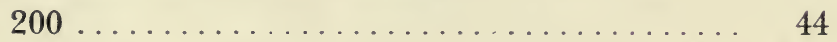

VI. Claudius Galen (A.D. 130-200) and His Influence on Anatomy $: \ldots \ldots \ldots \ldots \ldots \ldots \ldots \ldots \ldots \ldots$

VII. Anatomy in the Middle Ages-A.D. 400 to $1400 \ldots \ldots .58$

A. The Role of the Church ............ 58

B. Psychology of the Times.............. 59

C. The Arabs and the Reawakening ........ 61

D. The Universities of the Middle Ages....... 62

1. The University of Salerno......... 62

2. The University of Bologna ........ 63

3. The University of Montpellier ..... 66

4. General Information on Other Universities ............... 67 
VIII. Anatomy during the European Renaissance-A.D. 1350 to 1650

A. General Characteristics of the Period....... 68

B. The Mind of the Renaissance ............. 69

C. Status of Human Dissection on the Continent. . 71

1. The Church and Dissection during the Renaissance

2. Role of Artists in Anatomical Renaissance

3. Universities of the Renaissance.

4. Anatomical illustrations during the Renaissance

IX. Andreas Vesalius-A.D. 1514 to $1564 \ldots \ldots \ldots \ldots \ldots . . \ldots 9$

A. Introduction $\ldots \ldots \ldots \ldots \ldots \ldots \ldots \ldots \ldots . \ldots \ldots$

B. Early Life ....................... 91

C. Vesalius in Paris . . . . . . . . . . . . . . . 92

D. Professor of Anatomy at the University of Padua ....................... 95

E. The Fabrica $\ldots \ldots \ldots \ldots \ldots \ldots \ldots$

F. Vesalius $(1543-1564) \ldots \ldots \ldots \ldots \ldots \ldots \ldots . \ldots 102$

G. Vesalius and his Personality............ 104

X. Dissection on the European Continent and in Asiatic Countries during the Modern Period-A.D. 1650 to 1958

A. France ........................ 106

B. Germany .................... 108

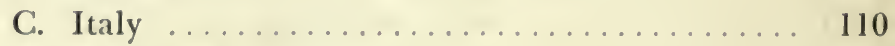

D. Holland ..................... 110

E. Austria ....................... 111

F. China ........................ 112

G. Japan $\ldots \ldots \ldots \ldots \ldots \ldots \ldots \ldots \ldots \ldots \ldots \ldots$ 
Chapter

H. Other Asiatic Countries

1. The Philippine Islands

2. Indochina

3. Iran

XI. The Rise of the Resurrectionists and their Methods in Great Britain-A.D. c. 1750 to 1832 .........

XII. Human Dissection in Ireland-A.D. 1590 to 1885

XIII. Human Dissection in England-A.D. 1510 to 1958

XIV. Human Dissection in Scotland-A.D. 1500 to 1958

XV. Early History of Anatomy in New England.

XVI. Human Dissection in the Medical Schools of New England

A. Harvard Medical School-A.D. 1748 to 1958.. 191

B. Berkshire Medical College-A.D. 1823 to 1869 . 209

C. Castleton Medical College-A.D. 1818 to 1861 . 209

D. The University of Vermont School of Medicine-A.D. 1822 to 1958

E. Vermont Medical College at Woodstock-A.D. 1827 to 1856 .

XVII. Human Dissection in the Middle Atlantic States.......

A. The University of Pennsylvania-A.D. 1750 to 1958

B. Early Dissection in New York-A.D. 1750 to 1790

XVIII. Human Dissection in the South Atlantic States

A. The University of Maryland Medical SchoolA.D. 1790 to 1958 .

B. Washington, D.C.-A.D. 1865 to $1900 \ldots \ldots \ldots$

C. Dissection in Virginia-A.D. 1830 to $1865 \ldots \ldots$ 
XIX. Human Dissection in the East North Central States

A. Dissection in Ohio-A.D. 1810 to $1880 \ldots \ldots 234$

B. Dissection in Illinois--A.D. 1850 to $1900 \ldots \ldots$. 241

C. Dissection in Indiana-A.D. 1880 to $1890 \ldots . .243$

D. Dissection in Michigan-A.D. 1850 to $1870 \ldots 244$

XX. Status of Human Dissection in the United States-A.D. 1900 to $1958 \ldots \ldots \ldots \ldots \ldots \ldots \ldots \ldots \ldots \ldots$

XXI. Chronological Highlights on Human Dissection ....... 257

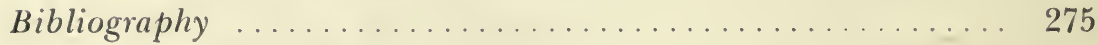

Index .................................. 287 


\section{HUMAN DISSECTION ITS DRAMA AND STRUGGLE}





\section{[I]}

\section{INTRODUGTION}

$\mathrm{T}$

he progress of medicine remained static and had to mark time for many centuries. It had to await one development, which was slow in eventuating, was attendant with great superstition, was unmatched for dramatic incident and heroism, was led by a small minority against the deep-seated resistance of the masses. In order to advance, it was necessary for the profession to reveal the accurate geography and architecture of man by permitting the restricted privilege of dissecting human bodies of a selected few from the general population. The means to this end has created an enduring, silent and gigantic struggle revolving around the use of dead subjects for the promotion of anatomical science. There is nothing in the life of man which is more attendant with fear, uncertainty, mysticism and superstition than his dead.

There is one way, and one only, in which the composition of man can be understood thoroughly and that is by dissection or "anatomizing" as it is sometimes called. This is true of every organic thing which an individual wishes to understand. All great thinkers on medical education have been in accord with this view. The parts of animals can be examined individually but cannot be put together again, whereas other machinery, with mechanical parts made by man, can be both disassembled and reassembled. Taking apart, however, remains an accepted method in teaching about functional units, the essential working organs of which are always masked.

In respect to the question of human dissection, it offers an opportunity for man to study man. The evolution of this practice has been such that the privilege has been granted to a few persons. Looking at it broadly, the spotlight has been focused directly and sharply on man's opinions and regard for the dead. Overcoming his objections, to human anatomizing, has been the 
big problem and at times it has been almost insurmountable. Death constitutes one of the three great enigmas in every normal person's life along with how he may have originated in a remote age and what he exists for. It is said that man has survived on earth for a million years, plus or minus. As a primordial thinking specimen, with little mental equipment, he entertained ideas about death and the hereafter. The remarkable thing about his first concepts is that they have been perpetuated millennium after millennium and accepted en toto by the masses, with little change or modification. There has been nothing so enduring and crystallized in the field of thought as the original analysis of the afterlife by the aboriginals. Perhaps ancient, prehistoric man should never be underestimated because he was endowed with a fertile imagination; he was a man with ideas, and of considerable stature when measured in terms of subsequent influence.

One of the first concepts conceived by the primitive of the distant past, was that of a soul, not only for himself, but for all living creatures and inanimate objects as well. The notion of immortality was born early in his evolution and it has never been neutralized completely through the intellectual ages of man, in which he has dealt with magic, religion and science, in that order. Since the post-mortem state has remained so unfathomable, it is possible that, through wishful thinking alone, the feeling about this spiritual essence may either survive for many centuries or permanently in human minds. The opinions which have had the longest past usually have the most prolonged future.

Ghosts, both good and bad, a product of man's imagination, have been with us from the beginning. Although little or no attention has been paid to the ones regarded as beneficial, those judged to be vengeful and vindictive have exerted much influence; they have acted as a whiplash to human behavior and thinking.

The sternest penalties have been meted out, even in the not too distant past, by religious or governmental authorities to any person or persons disfiguring or violating the so-called sanctity of the deceased human body. Death has been the maximal sentence imposed, imprisonment often under severe and harsh standards, a lesser, whereas some transgressors have been freed. The 
Church seems to have had more direct interest in this matter than the courts of justice possibly because it was concerned with what happens to human beings in the hereafter. It required a greater power than that inherent in the clergy to break down traditions, in this respect, which were about as deeply entrenched in the minds of man as anything could be, namely, that of a strong temporal agency.

It should be remembered that a part of the human race has evolved through three important periods: the savage, barbaric and civilized. The first refers to the state when all men were hunters and fishermen, the second to the introduction and practice of primitive agriculture and the third to a social culture characterized by relative progress in art, science and statecraft. It is only in the last era, beginning about 1500 B.C., during which there has been much advancement in the field of medicine. If the span of the civilized age has been about 4,500 years, then it is in the last one-eleventh of it, since A.D. 1543, that we can speak of major medical growth and scientific understanding. This amounts to about 415 years.

A.D. 1543 is mentioned above because it represents a landmark, not only in anatomy, but in medicine generally. It marks the date when Andreas Vesalius (A.D. 1514-1564) published his great work entitled, De Corporis Humani Fabrica Libri Septem or Seven Books on the Structure of the Human Body. It has been judged as a classic, one of the ten greatest contributions in the field of medicine. His pioneering research was responsible for setting the wheels of progress in motion, dating the beginning of the renaissance of medicine.

The story of anatomy before the middle of the 16th Century deals with the primitive, the mystic, the philosophic and only to a minor extent with the scientific study of human structure. Besides considering early aboriginal ideas about the human body, others are reviewed in respect to the ancient, civilized Egyptians, Hindus, Chinese and Hebrews; also the prevailing opinions existing in the following periods: Homeric, classical Greek, pre-Christian, Galenic and Dark Ages. It is on record that a start in scientific human dissection, under almost ideal conditions from 
the medical viewpoint, was made some centuries before the birth of Christ, but this practice survived only for a short period.

After A.D. 1550, with the Dark Ages past, a great struggle, lasting almost three centuries, took place in the British Isles between a handful of men, interested in the dissection of the human body, and the masses of people. A similar controversy was to follow in the United States, but it was of shorter duration. Without legalization of anatomizing, it became impossible to supply the demands of an ever increasing student body, made possible by the growth of new medical schools. The acceptance of medicine as a valuable and worthy profession was the stimulating factor behind this expansion. On the other hand, the populace wanted the institutions to maintain the highest educational standards medically; on the other, they were adamant about permitting them to use dead bodies for dissecting purposes.

The first legalizations of dissection on the human body were less than halfway affairs. Although permission to perform anatomies was granted in several of the European countries as early as the 13th and 14th Centuries, it was rarely done. They had to be performed publicly and then on the bodies of a few executed criminals. Because of the last, a stigma became associated with the practice which was to endure in the English speaking nations, until the passage of anatomy acts in the early part of the 1800's.

The most dramatic chapter in the history of anatomy took place between the time of Vesalius, from about A.D. 1543, through the first third of the 19th Century. During the latter part of this period, the demand for human bodies greatly exceeded the supply. This provided the impetus for the development and growth of the flourishing trade known either as "bootlegging bodies," "body snatching," "grave robbing," or "resurrection." By themselves, anatomists, surgeons and students were unable to successfully cope with the shortage. This phase was characterized by the organization of disreputable and piratical groups designed for one purpose, and that was to obtain human corpses to sell to the anatomical departments which were sorely in need of them. Nothing was too low for these men to stoop to, including murder. Great profits in this endeavor could be made with little or no 
initial outlay of cash or equipment. During the height of activity of these unprincipled gangs, no family, even the most respected and distinguished, could rest assured that one of its members, who had passed away, would be interred with any degree of permanence. It may seem paradoxical that the passage of the Anatomy Act, in England, in 1832, was expedited, when events got completely out of hand. In the United States, we have the historical reputation of having had more emotional uprisings, characterized by mob riots, as protests to human dissection, than any other nation.

Marked changes have occurred in the methods of teaching anatomy during the past century, in the United States particularly, since the privilege of dissecting human cadavers was legalized, to the satisfaction of the legislators if not the medical profession. This was due in part to the establishment and activity of standardizing boards organized by the American Medical Association, by the medical schools themselves, by licensing boards and by governmental agencies. The growth of new subjects and general financial considerations were also important. The last has probably been a vital factor in determining the status of medical education although it is not mentioned much in academic publications. These are facets of the history of anatomy which are discussed in the heart of the present text.

Gross anatomy, once pre-eminent, and almost the only subject taught in medical schools, with the assignment of many curricular hours, has necessarily had to integrate with the other new ones which have blossomed forth and expanded during the past few decades. The time which was originally assigned to it has been whittled away and it is possible that the end is not yet in sight for this eroding process. In an era where agitation is a prominent feature of medical education, anatomy has not yet found stability in the shifting sands of medical curricula.

The purpose of this book is to try to bring the great mass of knowledge regarding the role of human dissection in the medical profession into some kind of coherent, historical perspective, to discuss its signal events, not so much from the standpoint of the individual structures which were discovered from time to time during the renaissance of anatomy, which have been well-re- 
corded, but in terms of its drama and struggle to maintain its place in the hierarchy of subjects taught in medical schools. Much of it revolves around the procurement of cadavers, a problem which is universally becoming more and more acute. It is the story of two great opposing and divided, human forces, neither one of which has been able to win a total victory.

In spite of the highly adverse conditions encountered in unraveling and revealing the gross structure of man, the accomplishment has been worthwhile. This, more than other factors, has gone a long way toward neutralizing superstition, uncertainty and mysticism in medicine. 


\section{[II]}

\section{PRIMITIVE CONCEPTS REGARDING THE DEAD}

$\mathrm{T}$

he present chapter is an attempt to trace the evolution of the primeval mentality and reactions toward the dead in the belief that it is important in understanding the development of human dissection.

The definition of death as here used is the following: the "cause or occasion of loss of life." Probably prehistoric man puzzled more on this phenomenon than he did on any other theme. Because of his intellectual status, it was more of a mystery to him and his explanation as to its cause was unique and different than ours. Death has always been of more than passing interest to all generations of mankind; there are those who believe that both religion and philosophy are nothing more than meditation upon it (Metchnikoff, '07). One thing which seems to be certain is that the idea of the inevitability of death is a human acquisition. Some animals, like horses and steers, shrink from seeing dead bodies but they have no notion that it is an eventuality.

The nearest physiological event occurring naturally during life, with which the primitive mind could compare death, was sleep. So he called the former the "long sleep." He could see, however, that it was of a different kind. His earliest experience with it consisted of observing a tribal member, perhaps a relative, lying cold and silent, clammy to the touch, with glazed eyes staring into space. By contrast to normal slumber, he found that such an individual could not be aroused. The over-all picture was such that the presence of the dead filled him with terror, a powerful impulse to flee which he did, thus leaving the body to be ravaged by beasts of prey. Flight and total neglect of the 
human body was probably the first response of man to the death of his kind (Deniker, '06; Eichler, '24).

It is the unanswerable questions in life which arouse curiosity, stimulate the imagination and lead to superstitions. What happens after death can be placed in this category. Where does man go, is death the end, does he live again in another form when he vanishes into the great unknown and can he return to earth again? These became important questions to man as soon as he became able to think. One of the first concepts concocted by aboriginal man was that the dead live on as ghosts and then spirits. In a limited sense, he believed in immortality which today is supported by nearly every religion and numerous philosophies. It may not be an overstatement to say that this was one of the most momentous ideas conceived in the mind of man. The primitive savage went even further than this; he endowed all living and nonliving objects with an indwelling spirit (Eichler, '24).

The foundation for primitive man's concept of the human soul was probably laid not only because he regarded death as akin to sleep, but from the interpretations which he gave to his dreams, shadow, image in water and other similar phenomena. In his nocturnal visions, he could perceive himself, his friends, relatives, and the departed dead. The last came back to him in living form, conversed with him and performed deeds classified both as normal and superhuman. The impact of this was great on his naturally superstitious mind. It was logical for him to conclude that all human bodies were tenanted by a miniature spirit; that it constituted a vital principle responsible for all of his behavior, consciousness and movements; that it must be restless, wandering and sensitive, capable of escaping from its confines under minor or major provocations; that it could perform the acts of which he dreamed: hunting, fishing, fighting or other activities; that it possessed life beyond death and could continue to evince an interest in human affairs, both generally and specifically after death.

To the savage of the distant past, the soul was the double or duplicate of man or animal, an ethereal image much smaller and finer than the remainder of his body. Because he did not believe in uniformity, it was judged, according to his imagining 
faculties, to be either fat, thin, long, short, heavy or light. Longevity was associated with its size and children who died young were thought to possess the tiniest of all. Such a one had little staying power or energy, its delicate flame being extinguished early in life. The exact location of the soul within an organism differed depending upon the tribe: it was variously placed in the kidney, omental fat, heart, liver, gallbladder or in other structures, but not in the brain, as it often is today (Brown, '23).

The primitive assigned great flexibility, traveling power, transferability and even divisibility to his and other kindred souls. He was convinced that it could wander away, leaving him under manifold circumstances throughout life as well as at the time of death: while sleeping, during sudden fright, when sneezing or yawning, on the loss of his shadow, during an accident, when in a trance or when ill. The entrance and exit for this substance was considered to be the openings of his corpus, more especially his mouth and nostrils.

How did uncivilized man explain the etiology of death? His ideas on this subject were original and definitely settled in his elementary mind. It was not due to natural causes, but specifically to a mystic or supernatural force. He did not consider failure of bodily organs, senile deterioration or diminution of functioning power. He could see decrepit old people alive, changed to be sure, but still performing physiological activities. To him, man was always "doomed" to die by the malign influence of an enemy, in either human or spirit shape. There was no other cause. The guilty one might have been a wizard, manes (spirit of the dead) or another supernatural agent, less definitely individualized. Probably the cause was attributed most commonly to the machinations of a living sorcerer; this was important because it behooved the surviving relatives of a deceased person and other tribal members to search for the murderer and apprehend him as soon as possible so that he could do no further damage (Brinton, 1899; Levy-Bruhl, '23).

A sorcerer "doomed" an individual in one of the following manners: he took possession of something which belonged to him, such as hair, nail-parings, excreta, urine, footprints, shadow, likeness or name, then subjected it to his own form of magic art. 
He might have tried to act directly on the person or deliver him over to a wild beast, a snake, a malevolent spirit or an enemy (Brinton, 1899).

A person who suffered a violent death, as a result of an accident, starving during a famine, being hit by a thunderbolt, suicidal action or from the effects of childbirth was treated in a special manner. Because he had come to a "bad end" due to the wrath of unseen, occult powers for some crime committed, his soul acquired a disposition for evil beyond the ordinary. His body was strictly avoided and all relationship between him and the members of his tribe terminated immediately at death. The penalty to the living for not so doing was to share an identical fate.

The outstanding characteristic of primitive opinion regarding death, therefore, was that it was a manifestation of mystic or supernatural power working through the medium of ghostly spirits or the magical method of witchcraft. The aboriginal was impervious to the relation of cause and effect and no attempt was made to delve into the background conditions which produced this phenomenon. He lacked intellectual curiosity which was overbalanced by his extreme emotional response to death and accidents. Although, he might not show surprise at such events, it was sure he would show a strong sensitivity or feeling about them. Repeated experiences of the same kind taught him nothing as to the real etiology because he bothered little with logical coherence or abstract thought.

To the savage mind, therefore, there were two worlds, those of the living and the dead. In other words, the deceased were alive, at least for a certain time, and were considered to be personalized, intelligent agents of somewhat different shape than himself. As such, they were still able to participate remarkably in his daily life; only by slow degrees did a ghost cease to belong to his social group. In a sense, they were more important to him than his living associates.

The picture which the primitive had in mind about the ghost of a newly dead was not a salutary one. As a rule, it was evil-disposed and ready to do harm to survivors including its nearest of kin. It became irritative, vindicative, weak, unhappy and suffered while hovering nearby, watching its mortal body 
decompose. The intention of the spirit was always vengeful regardless whether it had been kind, considerate, loveable and amiable during life. There was an immediate and automatic transformation into a definitive, malicious personality. For example, if a person had not slain another during life, he would make up for it by killing several in his afterlife. There were a hundred or more ways in which a departed soul could show its displeasure. The only recourse in neutralizing such possibilities was to render customary dues and rites to those recently deceased.

One of the ways in which a dissatisfied ghost might strike was by trying to carry off a survivor by causing his death. This was because it felt lonely, forsaken and missed him as a friend. It wanted to have him near him in his new environment. Should a surviving relative or close friend fall ill and die at this time, all knew that it was the spirit of the newly dead which was responsible for the loss. Also, ghosts had a mystical influence over all natural phenomena: they could exert some measure of control over the rain, wind, sun, thunder and lightning. By this means, they could direct their activities to the physical detriment of the social group.

The effect which the recently dead could exercise over the living depended upon several factors, the manner in which an individual died, and his rank during life. The medicine man, chief, fathers of families and the men who died old and revered continued to be important after their demise in the eyes of the primitive. When such a person succumbed, there was added to his previous power, the mysterious and tremendous potential produced by his new condition as a ghost. He was now able to do much harm; he also occupied an invulnerable position because little or nothing could be done to him in return. Some tribes responded by mutilation of the dead, by allowing it to liquefy or by attempting to chase away or to mislay its spirit, but, in general, it was judged to be in order to try to secure its favor and to satisfy its requirements, whatever they might have been.

The ghost was considered to be most potent and vengeful immediately after death while his mortal remains were undergoing decomposition, more specifically until the worms began to destroy its body. Most activities designed to placate the soul oc- 
curred during this interval, which might be shorter in tropical climates for obvious reasons. By degrees, as the time passed, the primitive became reassured that the ghost's power had waned. Whether the funeral ceremonies were prolonged or not depended upon the dead man himself; if it was judged that he was instrumental in bringing all good things to his earthly survivors, the burial ceremonies were extended. By contrast, if nothing materialized in this respect, the memory of the dead was soon erased and people could go about their business as usual. An example of this, was that the marital partner of the deceased could remarry.

In respect to an afterlife, it was a natural development to think in terms of a home for departed ghosts. The choice of such an abode rested between heaven and earth. A spot beneath the surface of the ground, associated with a fiery hell, was popular for the lower tribes. Others selected were the following: a faroff island, a mountain top, a secluded valley and the sun or moon. The concept of an earthly paradise for departed souls, was strong among ancient savages; it dwindled during the barbaric stage and only feebly survived during the mediaeval period. However, the acceptance of Hades has had a firm place throughout history; Heaven has gained importance only in modern religions.

Although death seemed dreadful to most mortals of the past, there were probably variations in tribal sensitivities to it. The people of some groups could not bear the sight of a dying person (Abipone Indians of South America; Dobrizhoffer, '53); only old women were permitted in the death house and the body was removed from the premises while it was still warm. Others might be more passive about it.

Ancestral worship was a common practice among primitive tribes. What happened in this case, was a gradual transformation of ghosts into spirits; in so doing, human characteristics were lost. They became objects of homage despite the fact that they might have been either friendly or unfriendly, but mostly the latter, depending on their disposition. It was believed by some, that in any assemblage of dead spirits in the afterworld, those who were relatives would fuse together because of common interests in survivors. A pool, a higher power, exacting and demanding, was thus formed which had a terrible, collective power. This could 
be the source of all misfortunes which afflicted a tribesman and something which it was imperative to placate. Fear was the predominating emotion inspired by ancestors; they could behold all that was done by kinsfolk and if the latter were judged to be outof-line, they could send famine, warfare or any other disaster into their midst. The living were at a distinct disadvantage in such a situation because it was obvious that this invisible and potent force could not be compelled or coerced; the approach, therefore, was to make liberal offerings, to entreat, supplicate and cajole.

The greatest fear of the ghosts of the dead was generated when the bodies were lying exposed in huts or on the surface of the ground. Some natives threw their dead in isolated, jungle spots and left them to the ravages of physical nature and the animal world.

Other defensive measures taken against demons were as follows: desertion of homes to give the soul an opportunity to leave its body; burning all property of the deceased in the belief that it resided also in its belongings; marching behind funerals brandishing swords to drive the ghost away; eating special types of protective medicine at time of death; throwing the subject to wild and giant mastiffs, and dancing on a newly covered grave to stamp down the spirits.

The use of disguises by the survivors so as to become unrecognizable and impervious to the ghost at the time of death is an ancient custom. Again, it was based on fear. A variety of methods were used: smearing the body with pipe clay, mud, tar or white clay, hanging a chaplet of bones over the face, wearing a costume of either grass, veils over the entire body or mourning costumes covered with black paste. Savage people were strongly of the opinion that death was contagious, that they would suffer a like fate if they remained in the vicinity of the dead. Individuals became dangerous to the general society by virtue of having been present at the instant of death.

In some groups, such persons became unclean and were unable to mix with others for a definite period of time. Where cremation was practiced, the widow might have to carry the ashes of the dead around for two or three years, during which interval 
she was avoided. Tatooing and mutilation were practiced for the purpose of publicizing previous proximity to death.

The modern custom of temporary retirement from social life on the death of a family member originated from these old savage practices designed to warn fellow members against mingling with those intimately exposed to the corpse. In primitive times, actual existence was thought to be at stake so that very definite taboos were placed upon mourners and the mere mention of the deceased.

The motivating factor which lead to burial of the dead was fear of ghosts. They could either cause the "long sleep" by means of contagion or they could perform other vindictive acts. The procedure of choice was, therefore, to dispose of the body and demon at one stroke, in other words, the supposition and hope was that the ghost accompanied its relics. This was a part of the rationalizing behind the origination of the customs of burning, burying and other methods of taking care of the dead. Some measure of peace and security was apparently felt when a subject was buried five or six feet below the surface of the ground. This practice can be traced as far back as Neanderthal man, who lived in the ancient paleolithic period, perhaps a half million years ago; there was some indication that these primitive people buried their cadavers with food and stone weapons. At the risk of sounding gruesome, it can be mentioned that. sometimes the bodies were cut up before burial and parts of the flesh eaten. This was done out of a feeling of reverence for the departed; it was considered as an honor to the dead, the survivors hoping to retain some of the virtue and strength of the deceased. It was in this fashion that the breaking of the earth and preparation of the grave developed into a ceremony accompanied by dancing and feasting.

Eventually, death came gradually to be looked upon as the last great event of a man's life which should be duly celebrated. From the evolutionary viewpoint, at first it was only the important leaders, the strong men, who were accorded elaborate burial and ceremonial rites. Dancing and stamping were performed to frighten away the evil spirits whereas feasting and sacrificing were done in honor of the dead. Nighttime, with the moon 
shining overhead, was the time selected for these events. When that planet slowly faded from the heavens and the first golden rays of the sun appeared, the body was slowly lowered into a grave accompanied by more chanting and feasting. Thousands of years later, the rites became more ornate; the body was painted and decorated; there was great feasting and celebration, and weapons, food and ornaments were also put into the grave.

The position that a corpse was placed in its burial pit had varying significance to the savage. One method was to adjust it to a sitting posture, simulating the flexed attitude of a fetus. A second was to place it in a prone position, face downward, as a preventive measure against the re-entrance of the ghost leading to possible reincarnation. This was particularly practiced when the dead person was judged to have been of evil personality during life. A common procedure before actual burial was to carry the body feet foremost toward the spot of final disposition, in order to prevent its soul from seeing the death house. If such should occur, it could cast an evil influence upon the people in the form of sickness or death.

Going back into remote antiquity was the policy of using gravestones. Again, this was associated with the idea of evil spirits. Heavy stones were first used by placing them upon grave mounds in order to prevent them from arising and creating havoc among the living people. Marking graves so they could be recognized and identified also goes far back into the prehistory of mankind. This was-done, not only to keep the ghosts from rising and causing damage but also that the spot might be avoided by the living. Paleolithic man utilized headstones to mark the graves of their dead, whereas the neolithic tribes set up great stone megaliths above the mounds which hid the dead; it is not known how they were able to elevate these to a crosswise position.

Cremation was one of the earliest methods of disposing of the dead and, at one time, it threatened to become a universal custom. The reason for its use was that it was judged to be the simplest and most effective way of handling both body and ghost. It is still practiced in many places. In some territories, today, the people believe that evil spirits may pollute them until the corpse has dissolved and passed from view; great care is ex- 
ercised to avoid inhaling any of the fumes generated by the process of burning the body and all belongings.

There is another concept that is highly important from the standpoint of this discussion and that was a belief in reincarnation. It has numerous variations but the one that is pertinent here is that which holds that a spirit might return to its body making it possible for life to start anew. When the mind of man became more acute, it occurred to some, at least, that it was necessary to protect and preserve the corpse for fear of being judged as irreverent or in contempt. Therefore, the belief strongly developed that mutilation of a body would mean irreparable damage to the soul which flees from it. Some tribes believed so fully in this that when warring on their enemies, they would first attack the cemeteries, raise and maim the corpses, thus damaging their souls. Following this, they turned their attention to battling with the living.

Gifts to the dead originated in the belief that death was but a journey to another world and that the dying expected such ceremonies to be performed for them to expedite their travels, neutralize any dangers on the way and make it easier to gain admission to the new world. Money, food, clothes, chairs for the soul to rest on and messages and letters to carry to deceased friends and patriarchs were buried with the body. Sometimes, slaves were sacrificed so that they either could serve as valets for their master or bring news to the population of the dead. The more powerful and influential a person who died the more servants he deserved to accompany his ghost. In many early tribes, wives were sacrificed by burning or other methods, at the time of their husband's death. A widow, of her own volition, depending on custom, might strangle, poison or hang herself when her mate succumbed. This practice is dying out in many places but burning of effigies instead, occasionally occurs (Moore, '23).

In summary, it might be said that to primitive man there was no such thing as death. There was no word in his language which meant "to die" but only "to be killed" (Brinton, 1899). To the savage, all things lived on. A ghost could hover around familiar spots and visit the living in their dreams; its voice could be heard in the rustling leaves and falling waters. The aboriginal's reaction 
and behavior to ghosts of dead men revolved around the manner in which he treated the corpse, the modes used in mourning and the myths concerning the life and actions of the departed. A soul's power for good or evil, mostly the latter, were multiplied by deserting its body and entering another sphere of existence. The aim of each group was either to get rid of it, to secure its assistance or at least its neutrality by putting it to rest or sending it on a journey to a better land (Frazer, '48). 


\title{
[III]
}

\section{CONCEPTS REGARDING DEAD AMONG ANCIENT CIVILIZATIONS-3000 TO 1000 B.C.}

\begin{abstract}
The history written during the early part of our civilization indicates that an evolution occurred in concepts regarding death and the afterlife. Prior to this, primitive people had undoubtedly conceived the idea of a human soul and had heavily populated their world with unseen ghosts, practically all of which could do harm in manifold ways. Much of their daily behavior was determined by their mental reactions to them. The new thoughts which were introduced by certain advanced groups in this period were those of personal salvation and retribution in either a nether world or heavenly existence. What an individual did, therefore, during life could be of paramount significance to him after death. Associated with the origin of this novel trend, were specific myths revolving around events said to have happened during the lives of certain gods. The story of this development is intimately related to the genesis of the ancient religions which is so important in understanding human reactions to the dead. It is the purpose of the present chapter to review some of the highlights of these changes. The countries which will be considered in this respect are the following: China, Japan, Egypt, Babylonia, Assyria, India, Greece and Italy.
\end{abstract}

\section{A. China}

Primitiveness characterized the early religions and concepts of the dead in ancient China. In all cases, the cause of death was judged to be due to the malevolent action of demons. Avoidance of a death house or corpse was practiced because of fear of a possible lingering, angry, ghostly influence. Both nature and ancestors were worshiped. All powers were conceived in terms of localized spirits which could be celestial, terrestrial or human. 
They were ranked in the following order: those from heaven, earth, deceased emperors, sun, moon and ancestors. The rites of religion were a function of the state and were performed for the people, not by them. The emperor, son of heaven, was the ecclesiastical head of the nation and he alone could perform the ceremonies. By contrast, the classes privately venerated their forbears. The popular faith was practical, the aim being to obtain mundane goods and health in abundance during life.

In remote times, the Chinese believed that demons, ghosts, vampires and werewolves populated the country as thickly as human inhabitants and that they could do all kinds of harm. The life of man constituted an incessant battle against them; the only means of defense was considered to be the application of magic and the possible enlistment of their gods as allies.

The existence of the dead was imagined to be a ghostly continuation of earthly life in the midst of the living. It was important to them that the dead be properly interred. Great difficulty was often encountered and expense incurred in finding an ideal burial spot. Without this, the spirits might be dissatisfied and responsible for misfortunes in the family. Tombs were, therefore, built on a scale ranking next to those of the Egyptians in grandeur. The bodies were carried to the grave in a temporary structure and their souls were supposed to go along in a provisional slab or streamer. When the interment was over, a permanent tablet was brought out, in which the soul took its place; this was conveyed to its former home and placed on the shelf in the living room, in the company of other ancestral spirits. All significant family events were announced to it. There is on record the fact that living humans were buried along with their masters; in 619 B.C., 170 persons, including three high ministers, followed their superior to his grave. Another such incident was reported as late as A.D. 1398. Thereafter, puppets were substituted.

Confucius, born in 551 B.C., living in a time of great intellectual activity, was in favor of conforming everything to the ancient pattern. He believed that the destiny of states and individuals was ordained by heaven, that filial piety was the cardinal virtue and that man was good at the beginning of life, not necessarily so, at the end. He refused to discuss an existence after death 
maintaining that one could not know about this since he did not understand what constitutes life.

Buddhism was introduced into China as early as the 2nd Century B.C. It spread rapidly, even during the beginning of the Christian period, and no violence of persecution, individual or en masse, could neutralize it. The basis of its popularity was its doctrine of retribution, i.e., how one behaved during life was highly important in a hereafter. Its aim was not only the salvation of all mankind but of all sentient beings. This could be attained only by becoming perfect through Buddhahood. Prior to this time, the Chinese believed that the souls of the dead continued to exist, with no essential differences between them. The Buddhist teachers described in great detail the state of the departed, the blessedness of the good in heaven and the torments of the bad in hell. A great spirit, by name of T'ai-Shan, residing in a tall mountain, was the one who served as a judge of the Chinese dead. There, he had seventy-five hells, each one designed to promote the maximum in suffering for the ghosts of the condemned dead (Moore, '13).

\section{B. Japan}

The historical period of Japan began about the year 660 B.C. At this time, primitive Shintoism existed. It largely represented a survival of earlier times, especially in respect to myths which were abundant. The Shinto deities, which still exist in the minds of many modern Japanese people, stemmed from nature and natural forces. Heading the list of the pantheon was the sun goddess with a moon and star god on either side of her. Other important ones were the following: rain, storm, thunder, sea, rivers, waters in general, earth, food crops, mountains, trees and fire; in other words, all the constitutents of a natural polytheism. Besides these, were some who were once men; they were deified without any alteration of bodily form. All of the deities of nature were regarded as gods possessing human intelligence, form and passions.

These people developed a marked reaction to their dead; contact with a corpse made a person automatically unclean and it was necessary for him to undergo purification rites by ablution. Such contamination might infect a whole community, including 
the land. Defilement, disease and guilt, with no sharp line of division, were regarded by them as contagious evils, which were transmissible to other things, animate and inanimate.

The primitive Japanese first buried their deceased. The masses were merely interred by covering the bodies with soil in waste lands remote from communities. Since they entertained the universal belief in a life after death, with needs similar to those in the former, their post-mortem requirements were simple, nothing more than a little rice and water. By contrast, tombs or great megalithic vaults, covered with huge mounds of earth, were built for the royalty. Food, arms, utensils, ornaments and even living servants were deposited with them. The last barbarous custom was later abandoned and images were placed in the sepulchres as substitutes. This method of disposing of the dead slowly gave way to cremation which became universal by the 9 th Century A.D.

The ancient Japanese also believed in an abode for their dead; it was considered to be located either in the depths of the earth or beneath the sea. In either case, it was a place of utter darkness, loathesome corruption and decaying bodies. Existing there, were a group of ugly hags who fed upon the corpses. There was no notion of retribution beyond life. They did fear the dead, however, believing that their ghosts could cause all kinds of mischief. So they made many offerings to their forefathers asking for their protection and help in attaining some measure of prosperity (Moore, '13).

\section{Egypt}

Of all the countries of the early civilized world, Egypt undoubtedly ranks first in originating new ideas about what may happen in an afterlife. These people were very much concerned about the dead and they initially conceived the far-reaching concept of immortality and a possible retribution in another world; eventually they became bold enough to pioneer in making incisions on human corpses. The former was related to an intepretation given to an important Egyptian myth whereas the latter was associated with a belief in reincarnation which led to the practice of mummification. 
Primitive polytheism was the order of the day in ancient Egypt. Each of the city states had its own god who presided over the interests of its inhabitants and most were intimately related with some animal or plant: ram, cow, vulture, cat, falcon, jackal, crocodile, ibis and trees, among others. All were imagined to be endowed with human character and motives.

Certain powers of nature, such as the sun, moon, sky and the river Nile were also accepted as gods. By contrast, these were thought to bestow their blessings on all alike, not favoring the population of one locality over another. About 2750 B.C. the sun became pre-eminent as a deity; it was called $\mathrm{Ra}(\mathrm{Re})$ and was thought to have been created from sky and earth. At this period, the heaven was regarded as an immense cow, her four legs being planted at the corners of the earth. It was obvious to them that the sun traveled in a circle around the sky and underworld. Sometimes Ra was imagined as flying across the firmament in the form of a dung beetle, sometimes as a calf. It was often visualized as traversing its way along either the belly or the back of the sky-cow in a boat. When the sun went down in the west, the vessel was exchanged for another designed to transport a reborn sun. The nocturnal journey of $\mathrm{Ra}$ underneath the earth was divided into twelve parts, representing the hours of the night; each division consisted of fields, cities and dwellings, connected by a river and each was entered through special doors placed across the stream. Throughout this part of the trip, the sun was gradually growing to its full size, which it attained when it appeared at dawn.

All sorts of demons lived along the banks of this river of the underworld. Only a few favored ones, accompanied $\mathrm{Ra}$ on this part of his travel; when the sun-god was uplifted at the horizon, these selected spirits accompanied and remained with him, without losing their individuality.

The believers, who accepted the sun-god, Ra, were not as numerous as those who eventually accepted Osiris, god of the earth. The latter was also thought to have been created by the sky and earth. The myth relating to this god is as follows: he was treacherously murdered by his brother Set, following which his corpse was sought, in the underworld, and found by his wife, 
Isis. Ra, the sun-god, heard her wailing and lamenting for her lost husband, took pity upon her, and sent Anubis, a mortuary god, conceived as a jackal which ordinarily devoured the dead, to inter Osiris. Anubis assembled the various bones of Osiris, and bound them with a cloth in preparation for burial. Isis then fanned her wings and Osiris came to life, possessed of immortality. Thus, he had suffered, died and risen again to become judge of the dead as well as sovereign of the living. In the latter capacity he was associated with the fertility of the earth, the supply of water and the growth of vegetation. By some, he was also regarded as the procreator of man. Eventually, all of Egypt bowed down to him because belief in this tale gave each individual hope that he, too, could attain immortality by resurrection of his body after death. Its doctrine surpasses any other ever conceived in its preciseness and extent; it dates from remote antiquity, having been complete in pyramid times.

The important factors in the Osiris myth were that it outgrew all others, that it opened the door of hope to all Egyptians, that it became associated with the idea that horv a person lived in this world could be important in respect to the way he was treated in an afterlife. It came to be understood that uprightness and goodness commended a person to that god. All that was necessary, was to simulate the steps which made this deity immortal. This constituted the road to heaven (Moore, '13).

Mummification, or preservation of the human body, by a special technique, accompanied the spread in the belief of Osirian immortality; it became general about 1600 B.C.

The Egyptian particularly regarded some parts of himself as immortal: his personality, soul, shadow and heart. $\mathrm{He}$ anticipated that all of these could be brought together again in the other world by revitalization of his mummy, providing his soul, which he thought of as being winged, could pass certain tests. He considered death as being a long break in life without altering any of his former conditions of existence, during which his spirit would have to pass through different kinds of terrestrial, marine and aerial beings before it could again enter his remains. This transmigratory cycle might take 3,000 years. Destruction 
of his body (his mummy), in the meantime, would mean the loss of his soul.

When an Egyptian passed away, it was believed that his spirit had to make a long journey to the world of the dead, specifically to the hall where Osiris reigned as chief justice. Obstacles had to be overcome on every hand and in order to surmount them it was necessary to recite magical formulae and perform the proper rites for each. His ultimate success depended upon how well he learned these before death.

Eventually, it became the custom to put a written collection of magical spells at the disposal of a deceased in his burial chamber, to help him along his way. Collectively, these were called The Book of the Dead. Some of the dangers which could be encountered on the trip were the following: meeting hostile serpents or unfortunate dead walking upside down, fire, bodily decay and dismemberment. When a soul arrived at the judgment hall, it had to make negative confessions, denying each type of sin, of which there were forty-two. Finally his heart had to be weighed on the scales against the feather of truth. If it were successful in passing these tests, this organ was returned to its mummified body, upon which the immortal elements began to reunite. The individual concerned now entered a new life by becoming a complete and everlasting god, residing in a heavenly atmosphere where everyone was righteous and blessed. What happened to the condemned in hell is not known. It is told that they either were overthrown or destroyed.

From this background, it can be seen that anything which violated the physical integrity of the human body, was contraindicated. Although anointing, embalming and mummifying were accepted, requiring a total of seventy days to perform, little anatomical knowledge was gained; what was learned, was accidently acquired. In all preparations, the intent was strictly religious: to prepare the bodies for the hereafter. Destruction of parts of the corpse would neutralize the possibility of a functional existence in a resurrected afterlife. Mummies have been found with artificial legs, arms, teeth and eyes replacing any normal structures lost during life. 
Since the ancient Egyptian regarded life beyond the grave as a certainty, his tomb became a house of eternity, a suitable refuge for his immortal spirit. Because of this, he was not so much interested in making an accurate reproduction of his earthly dwelling, but rather planned to make it as permanent, safe and impregnable as possible. By the year of 3000 B.C., the simple grave had evolved into a bricklined or rock-cut chamber, surrounded by annex rooms, all of which were approached from the ground level by a long stairway. From a simple sand mound, a superstructure of masonry developed, which was rectangular and flat-topped. The next step was in the direction of the impressive, pyramidal form which was adopted around 2780-2720 B.C. Other less imposing types of tombs followed this period. The pyramids were constructed for the sovereigns to avoid stealing of mummies until such time, thousands of years in the future, when the spirit would be in a position to return (Addison, '32; Reisner, '12; Wiedermann, 1895).

Thus it can be seen that there were too many factors working against the practice of human dissection in early Egyptian times to make this a noteworthy anatomical period. These were inherent in the customs and religious beliefs which existed. Since the body was opened in preparation for mummification, the precursor of the anatomist was born in Egypt. The embalmers undoubtedly obtained some information about human viscera.

What anatomical information is known about this interval has come down to us in the form of a notable scroll, the Edwin Smith Papyrus (1600 B.C.). This is a surgical rather than an anatomical treatise. References, however, were made to certain bones in the human body, as well as to the heart and brain. That on the heart and its connections, is judged to be remarkable when taking into account the chronological period. In respect to the central nervous system, the convoluted appearance of the brain was described and the meninges and cerebrospinal fluid were mentioned (Elsberg, '31).

During a part of this epoch, namely 1502 B.C., there was another medical document, known as the Eber's Papyrus. Referring to the pulse it stated: "the heart speaks in all the limbs"; they, therefore, believed in the presence of vessels. This was dis- 
covered by the German Egyptologist and novelist, George M. Ebers in 1872. It was written in hieratic script and is lacking in general anatomical information (Ranke, '33).

\section{Babylonia}

Babylonia, which existed between 5000 and 539 B.C., in the area localized around the Persian Gulf, was characterized by being populated with people whose religious thinking was on a primitive, polytheistic level. Like Egypt, each city had its own god, which served as its protector and patron but others of various origin and type hovered nearby. Some of the earliest deities were identified with such celestial planets as the moon, sun and Venus. Spokesmen for the gods (priests) became the kings or rulers. One of the reasons accounting for the prevailing polytheism was that wars between the cities were frequent and the conquering groups were successful in imposing their gods upon the vanquished.

Basically, the universal belief of savages predominated in the thinking of Babylonians. Misfortune of every kind, especially those of disease and death, were thought to have been caused by evil spirits which were motivated either spontaneously or by instigation of human enemies. There was only one defense against these unseen essences and that was by means of magic, the use of certain gestures and words, which had to be developed to the level of a detailed and mysterious art; these rites were transmitted from generation to generation. The most important challenge in each situation was to detect the mischiefmaker; without knowing this, any magician was powerless to act. Shamanism was also practiced where a powerful spirit, under the dominating control of a sorcerer, might be ordered to detect the demon causing any specific trouble.

Eventually, the gods were solicited to defend the members of a city against malignant foes. A natural sequel to this was the development of the concept that demons have the power to harm the living only when permitted to do so by his own god or gods; these came to be judged more powerful than any ordinary human magician. Neutralization against injury was best performed, in the minds of the citizenry, by propitiation of a god who had been 
offended, followed by confession and contrition. Instead of being a dual affair, it thus evolved into a triangular situation: god, demion and man, with the first having some measure of control over the second and the second over the third.

The priests (rulers) entered the picture by conducting public ceremonies, which became a mixture of magic and religion. This supplanted the less official rites among the masses. These individuals tried to counteract the practitioners of the black art, the numerous wizards and witches who used their devilish art to injure and destroy honest folk, by using primitive sympathetic magic: making an image of the ones diagnosed as being responsible for the misfortunes and maltreating it in various ways, by burning or melting, shooting arrows or sticking pins into it, etc.

The Babylonians were pre-eminent in developing the art of divination. The specialists were learned men in all methods concerned with discovering the ways of strange and mysterious happenings. Unusual astronomical and meteorological events were everywhere regarded as ominous signs by priestly interpreters, who reduced them all into a system.

In harmony with this mental state, the possibility of a retributive hereafter, never occupied the imaginations of the Babylonians. They buried their dead simply beneath the houses in which they lived, sometimes in pottery coffins, great jars, or in reed mats. At funerals, officiating priests asked for and got extortionate fees. After interment, food and drink were offered to the dead. There was no suggestion of a final judgment or deliverance from the gloomy, nether world to which they were all assigned; this was conceived as being a vast cavern within the heart of the earth into which light never penetrated so that the everincreasing ghostly population had to sit in total darkness, with nothing but mud and dust available for food. Like all primitives, they were mortally afraid of the dead body and avoided it (Moore, '13).

\section{E. India}

India has had an interesting evolution in her religion and concepts of the dead. Going back to 1000 B.C., the people worshiped gods of nature which were neither tribal nor local. These 
were deities forced upon them by conquering Aryans during the second and third millenniums before Christ: the sky, air, earth and several classes of superhuman beings consisting of mythical heroes, priests and seers. It was the power in these that affected their lives; each was conceived as a spirit, actuated by a will and prompted by motives similar to those of man. There were no differences in either rank or religious importance, between the gods of the sky, atmosphere and earth.

Some of the manifold demons in their world were classified as unfriendly, devilish, natural enemies and evil. They spent most of their time harming man, in both person and property and were considered to be the antagonists of the gods. Primary attention was paid to these spirits. In terms of persecution, they performed their deeds by black magic and could assume, at will, the form of beasts or ill-omened birds. They were active at night, during the dark of the moon, and could enter man easily, unbeknownst to him, through his orifices, consuming his flesh, sucking the marrow from his bones, drinking his blood, confusing his speech and eventually making him mad. Outside of this, they could break up marriages, interfere with pregnancy and birth, swarm about the dying and haunt the houses of death. Diseases and ailments of all sorts were the work of this lot.

Besides possessing the power to attack persons individually, they could also drain the milk of cows, devour the flesh of horses and defile the spots where religious rites and ceremonies were held. To make themselves more potent, they were thought to come out in droves, in families and groups. The defense against these malignant and dreadful forces was either by means of counter-magic, proper behavior, making offerings and sacrifices or invoking the aid of the gods.

The Indians began to entertain ideas of retribution in an afterlife early, believing that the blessed dead have their abode in a heaven of light where they have immortality with all needs and wishes satisfied; by contrast, a hell existed beneath the earth for the punishment of the wicked. Between about 1000 and 800 B.C., Brahmanism developed as a priestly part of Hinduism. This religion believed in elaborate ceremonies, material offerings and animal sacrifice. The Brahman priests became a part of the 
caste system and elevated themselves to superhuman rank. A belief in transmigration, a re-embodiment of human souls in man or beast, appeared approximately 800-600 B.C. This was not an original idea since it was characteristic of the primitive savage. Residence in either heaven or hell, therefore, came to be thought of as a temporary state of retribution between successive embodiments of a soul. What the Indian strived for, was to save himself from going through an endless chain of lives and to think in terms of his future caste, sex and fortune.

Another feature of early Hinduism, was the burning of the dead, with the exception of children and great saints. It was customary to carry the body to the shore of a holy river before death. If this were not feasible, special precautions were taken to keep the messengers of hell at bay, such as surrounding the bed of the dying with a ring of cow dung or putting a sacred stone or plant by its side. Another way to neutralize the powers of these spirits of the devils was to have the dying man grasp the tail of a cow which would assure him of being transported across the waters of death.

Special rites attended the burning of a corpse which was performed on an open pyre. An important part of the ceremony was to crack open the top of the skull with a strong blow from a club, but not until the body was partly consumed. This was done to permit a still vital soul an exit for escape. The bones which remained were collected in an urn and buried in the ground; they were later resurrected to be thrown into the Ganges or another sacred river.

Since a part of the creed of Hinduism, was a belief in a temporary stay in either a heaven or hell, a few more facts may be mentioned. Persons reaching heaven, spent a long time in a state of conscious blessedness. At the other extreme, there were from twenty-one to twenty-eight hells presided over by a judge and executioner, named Yama. At death, he sent two of his messengers to where the cremation was performed. When the soul of the deceased escaped through the artificially produced opening in the cranium, they captured and bound it and then hurried to the seat of judgment. Thirteen days were required to pass muster in the court, during which the soul grew into an intermediate 
state. If it were judged to be a sinner, it was conducted to hell, a distance of exactly 86,000 leagues; even on this long journey, the unfortunate spirit was subjected to minor torments as an example of what was to come: it was exposed to heated cauldrons, red-hot irons, a lake of blood, stinking mire, a jungle where the leaves were as sharp as knives, a plain dotted with iron spikes and a pair of pincers devoted to tearing the flesh from bones.

Although Zoroastrianism originated in Persia, it spread to parts of India toward the end of the 7th Century, B.C. Briefly, Zoroaster, its founder, rejected the myriad gods of his age and concentrated on the spirit of the good. He attempted to establish a monotheism which would liberate man from loyalty to the numerous deities connected with magic; he thought in terms of a single god who was flanked by evil spirits. This leader maintained that there was a life after death, among other things.

In this religion, uncleanliness was due to the contagion of demons. Death was caused by those which were imagined to exist in the form of a carion fly. The greatest precaution was taken against the machinating of such a spirit. When a man was judged to be dying, a priest was called in to hear a confession and put liquid drops into his mouth as a last sacrament. This type of demon could be frightened away by a dog or it could be killed by an odor produced by a fire fed by a sweet smelling wood. A priest was required to sit exactly three yards from the dead, reciting verses until the funeral procession began.

The burial procedure followed certain standards: it took place in daylight without rainy weather, the body being transported on an iron bier; the pallbearers wore protective material to guard against possible infection. First, the body was interred in an isolated spot; later it was elevated to a "Tower of Silence." Behind these actions, was the desire to prevent the defiling of the elements; in sharp contrast to the Hindu practice, it was considered a sin to burn a corpse, to deposit it permanently in the earth or cast it into the water. Prayers for the dead were recited while the vultures made quick work of the flesh of the cadaver; the bones once dry were no longer considered as unclean; they could then be cast into the central pit beneath the tower. 
Contact by a living person with the dead, from which the devil had not been driven out by beasts or birds of prey, meant that he became possessed by the demon who caused the death: the individual was then required to undergo, purification rites by a time-consuming procedure which included basically washing with the fluid thought to be the best active disinfectant, cow's urine. If a dog died in a particular field, it had to lie fallow, by custom, for a year. The ground in which a human body was buried remained unclean and condemned for fifty years. If a corpse was found in either running or standing water, it became impure, for how long, was a subject of great debate. Eating human or dog flesh was a monstrous sin which could never be atoned. Up to 1,000 lashes with a horsewhip were given to a person throwing away any part of a dead man or dog the size of a joint of the little finger or larger. The body of a beast considered to be endowed with an evil spirit, a worshiper of idols and a heretic were not judged to be unclean because the devil in them had gone off with their souls (Moore, '13).

\section{F. Greece}

The Iliad, written by the Greek Homer, who lived between 900 and 800 B.C., portrays some habits and beliefs regarding the dead. In terms of chronology, the following discussion refers to the era approximately 1,100 years before Christ.

Numerous gods were worshiped and their place of assemblage was on Mt. Olympus, the highest peak in Greece. Zeus, the leader, a sky god, was judged to be the offspring of Cronus, a vague nature power. He was the most powerful, unprejudiced and farseeing of the gods. Ranking below the select group of deities, were many lesser sprites: river gods, sea nymphs and fauns of the wood. The oldest and most sacred things of all, however, were the sun, sky, earth, rivers, the underworld and the "falling water of Styx." The last was the river which circled Hades seven times. It was to these, rather than the gods, that sworn and solemn oaths were made. Heroes, legendary founders of cities, ancestral heads of families and historical persons were also venerated. The good will of the gods was obtained by means of sacrifices, performed in grand style; 100 bulls and sheep were frequently offered at one 
time. Pouring out wine, prayers and sometimes hymns accompanied the meat offering.

There were limitations as to the power of the gods over mankind. They could not always save their favorite mortals from the consequence of their own misdoing as retribution was judged to be an inherent law of the universe which even the deities could not break, nor could they make them immortal. The final lot of mankind was to go weeping down to the house of Hades as a wan, bloodless and mournful shadow of its former self. There were even standards to be met for entrance to this place in the form of proper burial. If not, a spirit might have to wander desolate outside of the gate, having lost forever the opportunity of gaining the companionship of the souls assembled inside.

The intervention of gods and the importance of proper burial rites are poignantly emphasized in the last chapters of the Iliad, dealing with the Trojan War, where Achilles bound the slain body of Hector behind his chariot and proceeded to drag it ingloriously on the ground, full length, with face downwards. Hector lay on the surface of the earth twelve days, intermittently being pulled furiously around; yet his flesh did not waste and the worms did not eat him, because he was protected by the god, Apollo. He lay there fresh as dew, not marked or disfigured in any way, until his father was finally given the humiliating experience of claiming him. During the battle between Achilles and Hector, when the latter was mortally wounded, Achilles threatened his victim by saying that he was going to let the dogs and vultures ignominously devour his body. The dying man pleaded to have it burned, which apparently was the accepted method of disposal. It was believed that this procedure would properly release the soul for entrance into Hades.

Some of the funeral pyres built in that day attained great size, up to 100 by 100 feet, which required a considerable amount of wood gathering. For important persons, it was the custom to follow the burning with a great spectacle of sport contests: chariot and foot racing, boxing, wrestling, sword fighting, hurling an iron quoit, archery and javelin throwing, all of which was thought to make it easier for the departing soul to gain proper entrance into Hades. 
The Greeks of the later civilization, before the 4th Century B.C., shared and cherished the belief that death was not the end of existence, that man lives on by means of his soul. They were influenced by certain myths of the gods, particularly those concerned with the soil, crops and the abode of the dead. In nature, things come back to life again and again as evidenced by the seasonal rebirth of plants and the reappearance of hibernating animals, therefore, why not man. At first, it was felt that blessed immortality belonged only to the gods. The common man was first interested in and looked to those deities who had experienced struggle, pain and death (Dionysis and Demeter), who had triumphed over death and risen to a new life. In such a victory, was the evidence that death can be overcome; therefore, the only hope for man to escape from the gloomy underworld was participation in divine nature.

From the 6th Century B.C., the myth of Orpheus, Thracian singer, son of Apollo, wielded great influence among the Greek population. He descended to the underworld with his lyre in an attempt to save his wife, Eurydice, who died after being bitten by a snake. His music so charmed the queen of Hades that she gave Orpheus permission to let Eurydice follow him back to earth on condition that he would not look behind until they reached the upper world. On the upward journey, because of his emotional condition, he ventured a glance in her direction and she vanished. Thereafter, Orpheus mourned her loss and scorned the women of Thrace. This so infuriated them that they tore him to pieces in an orgy. They cast his head, which was still calling for Eurydice into the river Hebrus; it floated down to the shore of Lisbon, which thereafter became renowned for its lyric poetry.

According to the Orphic doctrine, at death the soul was carried around upon the wings of the wind until it found another body, a primitive concept of transmigration. The human frame, therefore, was nothing more than a prison for this essence and freedom could be attained only by deliverance from it. The concept of the Orphic hell was on the gruesome side. It was a place of misery where the souls wallowed in filth, where an earth dragon with 100 heads existed which could tear out a man's vitals; which contained a Spanish sea serpent which could claw their lungs; 
also present were the Tithrasian gorgons, capable of tearing kidneys and entrails to pieces. In contrast to this, nothing but bliss existed for the saved who were pure, holy and righteous.

The Orphic doctrine addressed itself to the individual; it set forth a plan of salvation by which a man could purify himself; it permitted the offering of sacraments and mystic rites whereby he could partake of the divine nature; its myth and ceremony excited the emotions and its primitive theology offered to thinkers a solution of the problems of god, the universe and man. It had an important influence on the development of the hell of Christianity even to the Middle Ages (Moore, '13).

\section{G. The Romans}

The Romans took much of their mythology, religious art and philosophy from the Greeks. Each human had his personal deity who was conceived as operating in specific spheres of nature and life. The oldest order of the gods were Janus, Jupiter, Mars, Quirinus and Vesta. Religion was at first treated as an institution by the state. At the time of the monarchy, the king was head and priests officiated. When church and state separated, the college of Pontifices assumed control of the church. Ceremonies prevailed and offerings were made both publicly and privately; images of gods and their symbolization were unknown and no divine dwellings existed. By the year 205 B.C., the whole Greek pantheon was annexed to the Roman religion.

For these people, there existed a nether world of the dead, especially for their forefathers. Spirits of ancestors were thought to watch over each house and avenge infractions of family ordinances. They possessed no clear-cut idea of the state after death including that of retribution. Populating their own world were ghosts, spectres and bogeys. By means of aversive rites and offerings, they attempted to keep them at bay.

Even some of the priests were not permitted to come in contact with a dead body, approach a grave, touch or even name things associated with death and the nether world: such as goats, dogs, beans and ivy.

At the beginning of the Christian era, the worship of deified emperors was developed, Julius Caesar being the first. This prac- 
tice served to unite the diverse peoples and religions of the Empire, but other gods also existed in their lives.

Attis, an Oriental god, from ancient Phrygia, central and northern Asia Minor, became an outstanding figure because he gave the Romans hope for a life beyond death. What men and women began to think of was salvation for their souls. Even more influential was the religion centering around the Egyptian goddess, Isis, carried into Italy by merchants and seamen as early as 105 B.C. In spite of disfavor by the authorities, it thrived and spread; it became the most civilized of the various Roman religions and offered the possibility of a blessed immortality and the hope of a new life which were welcomed by the common man.

Another Asiatic religion which gained a foothold in the Roman Empire, was the worship of Mithras, an old Indo-Iranian deity. It spread rapidly by means of lip service of Roman soldiers; in many regions, it became the chief rival of Christianity. That deity was a god of light, and in the moral world, god of truth and good faith, a righteous and heroic judge. He was regarded as a champion of every good cause, a defender of the upright in their conflict with the human and devilish powers of darkness and had the power to rescue their souls at death from the assaults of demons. Its big attraction, however, was its concept of salvation.

Finally, Christianity, another Oriental mystery, was introduced to the Romans. It offered nothing new in the way of rites with its gospel of the cross and resurrection, baptismal initiation, sacrament of bread and wine, body and blood of the Redeemer, and its hierarchical organization of the clergy. It differed from other religions and cults in its intolerant attitude toward other ways of salvation (Moore, '13). In the 2nd and 3rd Centuries after Christ, persecutions became common. By the 5th Century, the demise of heathenism occurred and the older, competing religions decayed and disappeared. 


\section{[IV]}

\section{PRE-ALEXANDRIAN ANATOMY-1000 to 300 B.C.}

$\mathrm{W}_{\mathrm{n}}$ the period immediately before the development of the Alexandrian School, beginning about 332 B.C. is speculative (Kempf, '04; Singer, '25; Taylor, '22).

In Egypt, medicine lagged behind achievements in the arts although the Egyptian embalmer can be classified as the precursor of the anatomist. It was he who was one of the first to view some of the organs of the human body. During that remote era, the populace had definite, antagonistic views concerning those who tried to dissect. No qualms were felt about killing a man or satisfying vengeance on the body of an enemy after death, but it was a different matter when a corpse was cut for the purpose of learning structure. Anatomy was a mixture of mystery, imagination, and a few facts learned in everyday life. Magic continued to play an important part in the religious and commonplace existence of the Egyptians and was applied to the dead as well as to the living (Cave, '50; Frazer, '20; Haggard, '29; Wright, '18).

Although it may seem that their knowledge of human anatomy was vague and retarded in Egypt, there is little doubt that it was ahead of contemporaries in other parts of the world. This was possible because the Egyptians pioneered in the art of embalining; they were the first to open the dead for what they thought was a practical purpose: namely, to preserve it for reentrance of its soul; the motive was, therefore, religious, the process of mummification being important to them in respect to what happened in the afterworld. Certain of the viscera were removed, in the embalming procedure, so that it was natural that they gleaned something about the topography of the body, particularly in the thorax and abdomen. Names were given to some 
of the organs and a deity, which had a life of its own, was identified with each. There were over 100 anatomical terms in the Egyptian language of this period. It began largely as a mythological anatomy, of which traces still exist in terminology; e.g., the word, Atlas, which refers to the first cervical vertebra.

The human body was regarded as a microcosm reflecting the macrocosm, or universe. The morphological parts were able to wander around the body at will; they had appetites, whims and moods which had to be pacified and satisfied (Sigerist, '51). Organs were also divided into good and evil, most of them being in the latter category; only the heart and kidney were judged to be untainted and were the two left within the mummified body; the others were removed or destroyed with chemicals while they were in situ. The Egyptian considered the heart to be the most important, serving as the center of the vascular system and the seat of intelligence and all emotions. However, he was unable to differentiate, between arteries, veins, nerves and muscles.

One of the greatest fears the Egyptian embalmer had to overcome was the mere opening of the abdomen. He tried to negate the displeasure of his particular gods by hiring a scapegoat, in the form of an old, depraved man, to make the incision with a sharp stone; the use of iron was not permitted because of a stigma attached to its use. Once the cut was made sufficiently, the man employed for the occasion ran off as fast as feeble legs would carry him. During his escape, the undertakers hurled rocks at him, to demonstrate to the deities, that they were righteous and disapproved of the mutilation of the corpse. The practice of mummification reached its height about 700 B.C.

In the final analysis, Sigerist ('51) states that probably more was learned about anatomy in the kitchen or cult than from observations made in the embalming procedure in Egypt. To give credit where it is due, however, it must be admitted that the art of mummification was instrumental in reconciling the popular mind for the following twenty centuries to the idea of incising the human body. This custom made it possible for a number of outstanding Greeks to openly and systematically study the human body later in Alexandria, a privilege that was denied to them in their own country because of religious and public odium. 
According to Dawson ('53), true medical science owes its start to the single fact that the pre-Christian Egyptians dared to open the body of man, for the first time.

The spiritual and political climate in pre-Alexandrian Greece was not conducive to the development of human dissection; it was actually banned because of the existing laws, customs and prejudices. Prompt burial was required for the dead and they had to be left in peace; generals of the army, for example, were given the death penalty for failure to either bury or cremate soldiers slain on the battlefield. With the medical teachings of the time, there was perhaps little need of a knowledge of specific structure; mere crude, stylized, anatomical figures sufficed (Anson, '56).

Anatomy was in a crude state before the time of Aristotle (384-322 B.C.), who was unquestionably the first real comparative anatomist of any stature. It was he who said that the "inward parts of man are known least of all" (Osler, '22). Bailey ('11) states that anatomy was a mixture of symbolism, conjecture and philosophy, which collectively was too uncertain to use as a foundation to build on. It was an examination of open wounds, injuries and disintegration of exposed, unburied bodies which disclosed some of the integral parts of the human body. Some mammalian anatomy was also learned from sacrifice of different animals.

Some of the factors militating against performing human dissection were the following: The Greeks were taken with the study of philosophy and were blinded by its brilliance; it became authoritative and was used to explain all things (Browning, 1894; Camac, '31; Jonas, '22). Another which may have been of significance in retarding studies, were the priests of Asklepios, followers of the Greek mythological god of medicine; they practiced a secret and hereditary art in this field. They wrote no texts and all medical information was kept within their cult, being passed on secretly from generation to generation. The priests were revered both for their divine and health-giving powers. One of the first to question the methods of this group was Hippocrates (Coleman, '50; Cumston, '26). Galen judged one of the last of these priests, Praxagoras (c. 300 B.C.), to have been a very poor anatomist. 
A little later (280 B.C.), the school of Empirics was ill-disposed toward human dissection, as well as toward reason. They held that the search for ultimate causes in disease was in vain, although they were active in endeavoring to discover the immediate etiology. Anatomy, they believed, could be learned by chance. They paid particular attention to the totality of symptoms. The Dogmatists, another medical sect, of the time, cared more for rigid doctrine than for investigation. Although a few had enough desire to progress, it was not sufficient to overcome their innate repulsion against violation of the dead.

An additional consideration is that the Greeks believed in the supremacy of the soul over the body. The dead were shrouded in mystery and a ghost would avenge any amputation or mutilation of its body. Death was not regarded as the end. Like the inhabitants of Egypt and other parts of the ancient world, the preAlexandrian Greeks were interested in the possible location of the soul.

During the golden age of Greece, numerous renowned philosophers advanced their personal opinions on a possible life after death. Pythagoras (582-507 B.C.) believed in salvation and transmigration. To him, matter was the basis of all evil; since the body was so constructed, it was corrupt. The soul was also material but it emanated from god.

The concept of a single, all-powerful god, began to be expressed at this time, more particularly by Xenophanes (c. 536 B.C.). His deity was not like human mortals in form or thinking, but was the universe itself, endowed with purpose and the faculty of thought. Parmenides (c. end of 6th Century B.G.) conceived the world as a unity, unchangeable and immovable. He regarded sense perception as an illusion based on the false opinions of man, which revealed a world of plurality and change.

Plato (427-347 B.C.) promised salvation believing that the soul was immaterial, immortal and divine; freed of sin, it ceased transmigrating and was reabsorbed into god. Sinners, in life, were destined to go to an eternal hell, an idea which was transferred to Christian thought. Both Aristotle and Epicurus (342270 B.C.) were against the concept of immortality. The Stoics (starting about 308 B.C.) held that the body was the prison of the 
soul and that the latter was liberated to be judged at death. When it joined the blessed ones, nothing but eternal peace lay ahead. The ultimate fate, however, was that all would be destroyed by a great conflagration at the end of a certain era.

The situation in Italy was probably more primitive than in either Greece or Egypt. It was entirely against Roman beliefs to perform human dissection. The body of man was held in great respect and a belief in resurrection prevented physical dismemberment. Even looking at a corpse was prohibited by Pontifex Maximus (Gordon, '42). Not even a human skeleton was known to exist in Rome up to Galen's time.

Human dissection was precluded among the Hebrews of the pre-Alexandrian era both because the people regarded the body as unclean and because of their belief in resurrection. Even touching a corpse or entering a room with one in it, contaminated a person. This was propounded in the Old Testament. If such a contact occurred, it was necessary to be isolated for at least seven days and then purified (Gordon, '42, '44; Guttmacher, '35; Haggard, '29). Very little human anatomy was expressed in the Bible.

China probably, as a whole, has been one of the most backward countries in respect to legalizing human dissection. Although there is some evidence that it was practiced temporarily as far back as 2700 B.C., this was undoubtedly an oddity (Castiglioni, '4l), for it was not legalized in that country until about A.D. 1913 (Cowdry, '20a, '21). Osler ('22) states that early Chinese and Japanese medicine gives the impression of impalling stagnation and sterility. The Oriental religions, especially that of Confucianism, were such that touching the human body under certain conditions was considered unholy (Haggard, '29; Hume, '30).

References were made to the human body in the earliest Hindu writings (Vedas). There is little question that the people of that remote era generally stood in awe of a dead person and severe penalties were imposed for molesting it. The only way primitive, anatomical knowledge was gained was by observation of bodies dismembered by war, in the chase or by accident (Barker, '01). 
For centuries, the basic text of Hindu medicine was the Susruta. According to this ancient classic, the human body was composed of 300 bones, 90 tendons, 210 joints, 500 muscles, 70 blood vessels, 3 humors, 3 secretions and 9 sense organs. Other structures were also known. The suture of the skull was regarded as the place where the spirit entered man after creation (Castig. lioni, '41; Hammett, '29).

There is, however, some evidence that the early Hindus may actually have examined the human body. Physicians enclosed subjects in a bag and allowed them to decompose for nine days in a river. By this method, the internal organs could be disclosed without utilizing a knife; the use of this metal instrument was forbidden by Hindu religious laws (Castiglioni, '41; Bacon, '03).

There is unanimous agreement among authorities that all dissection was utterly excluded by Arabian religious beliefs (Chatard, '08). In addition, the physician felt no need for a knowledge of the subject (Coleman, '50). Otherwise, these people were advanced in medicine although they subordinated anatomy and surgery (Haggard, '29). Khairallah ('42) states that Mesüe, Sr. anatomized a monkey and wrote a book on his observations; he threatened to do the same to his weak-minded son after his death. Like peoples of other countries, the Arabians were interested in localizing the soul; they believed it was situated in the liver.

The Babylonians likewise had some knowledge of anatomy. Their book, Talmud (5th Century B.C.), contained a number of interesting anatomical facts. Described therein were parts of the gastrointestinal, respiratory, genitourinary, cardiovascular and other systems. They also localized the soul in the liver. 


\title{
[V]
}

\section{THE ALEXANDRIAN SCHOOL OF ANATOMY-332 B.C. to A.D. 200}

\begin{abstract}
A
Ithough the classical Greeks did not permit human dissection in their own country, for reasons which have been outlined, they were not averse to having it carried on in one of their conquered territories, specifically in Alexandria, Egypt. During the pre-Christian era, the setting was ripe for anatomical pursuits in man, but only temporarily. That city became an important center for learning, because many people who had been granted religious asylum there, were anxious to avail themselves of the pre-eminent facilities offered for study at the famous city library and museum. The Platonic and Stoic schools of philosophy were undergoing deterioration, monotheism was in vogue and Judaism flourished. Attempts had been made to combine Greek philosophy and Hebrew theology, and a belief in Gnosticism was gaining headway.

The last is of importance in the history of anatomy because the Gnostics (a philosophic-religious movement which believed that emancipation comes through knowledge) held a disdain for the human body. To them it was merely a prison for the soul, which was inalienably immortal, existing from eternity to eternity. The Alexandrian men in this group concluded that all men pass immediately at death to their final lot: the ghosts of the wicked went to their doom with suffering, the good to absolute perfection through a series of transmigrations after which they would exhibit no interest in mundane affairs. In practice, the followers of this creed were either rigorously ascetic or completely licentious. To these individuals, life was an unpleasant interlude so death was welcomed (Wood, '20). It was largely because of this adverse regard for the human body that there developed a relaxation of popular prejudices whereby the first unequivocal dissections were sanctioned on man. Taking advantage of this
\end{abstract}


rare opportunity were two men, Herophilus and Erasistratus, the former antedating the other by a few years.

Responsible for the magnificent development of Alexandria as an educational and medical center, was the great conqueror Alexander the Great, who founded it in 332-331 B.C. Europe was then in a state of war. To this metropolis, he and his successors were instrumental in bringing some of the intellectual and materialistic riches of the universe which were placed at the disposal of distinguished scholars who labored to benefit mankind. Manuscripts were rare and costly, sometimes only one being available. They were preserved in families with religious care and a single book was regarded as a precious heritage. As much as $\$ 15,000$ was paid for an original volume written by Aeschylus, Euripides or Sophacles. The establishment of the public library and museum constituted an act of philanthropy and liberality unparalleled in subsequent history (Fisher, 1881a; Weaver, '30).

It was Eumenes of Cardia, who was the head of the secretarial or historical department belonging to Alexander the Great. He accompanied his king on all his expeditions to Asia, and through his efforts, was able to collect about 700,000 volumes, which were assigned to the Museum and Serapium at Alexandria: 400,000 to the former and 300,000 to the latter. This collection had a marked influence on the study of medicine and other fields and helped to make the school the leading institution of its kind in the world, completely eclipsing those at Cnidos, Cos and Pergamon.

The first Ptolemy, who became governor of Egypt, was Soter, brother of Alexander the Great. After the latter's early death, he attempted, with some success, to neutralize the central Greek authority and consolidate his own. Unlike some other leaders of his period, who devoted all their attention to armies and invasions, he interested himself in commerce and art. It was he who was instrumental in attracting around him some of the ablest and most erudite men of his day. He provided them with suitable homes in the immediate vicinity of the libraries, fed and endowed them with adequate salaries. Although he gave orders to classify and collate all of the assembled treatises in every branch of learning, as well as give instruction by means of lectures and discussions, it was medicine which received the most encouragement. 
Because these presentations were called the "Feasts of the Muses," the locale where they were held became known as the "museum." Ptolemy participated in some of the events. It became the rule to announce forthcoming subjects in advance, so that the public was informed. At the conclusion of the lectures, the teachers receiving the most applause were compensated accordingly.

The opportunities and atmosphere which prevailed in Alexandria were such that students flocked there from all parts of the then existing world (Gask, '40). The three things necessary for academic learning were there: buildings, teachers and students. Interested in the things of the mind, thoughts mingled leading to new ideas, which became crystallized to the extent that old religious dogmas were abandoned (Haggard, '29).

Not all authors are complimentary to the standards which existed at the school of Alexandria. Dana ('28) states that the program which developed was kept up for vanity rather than true love of science. Soter, he claimed, was more concerned with establishing a reputation for the center, that his teachers were pedants and not scholars, that many books were of no value, that the inquiries were petty and that there was boastful advocacy of special theories. Walsh ('35) also libels and censures the teachers, to some extent, as follows: they withheld knowledge of their discoveries from their students and all their teaching was confined to the texts at their disposal.

Participating in this intellectual climate, such as it was, were the two outstanding pioneering anatomists previously mentioned, Herophilus and Erasistratus. They established a school of medicine at Alexandria which flourished for 300 years and lived 1,000. They must be given credit for developing anatomy into a distinct branch of science. The first to use the scalpel, they laid bare many secrets of the human body and succeeded in making a step forward in correcting existing ideas, based on animal dissection (Buck, '17). Galen called them the "ancient authorities" (Corner, '30). There is some reason to believe that this pair of transplanted Greeks had more to do with making the city eminent than any of the numerous other physicians who participated in the over-all program. All that was needed, was permission to dissect human bodies. The authorization was by royal decree and it 
supplied an impetus to medicine which was unmatched elsewhere. It was only necessary for a student to have studied in Alexandria for a short time to obtain the reputation of being a physician. The fact that the Ptolemies, father and son, condescended to take knife in hand and dissect along with these two anatomists did much to dispel the antagonism against the practice.

Herophilus (c. 350-280 B.G.) was the first person to open the body after death for the purpose of discovering the character and course of disease. Born in Chalcedon, Asia Minor, he studied under Praxagoras of Cos (Fisher, 1881a). Fallopius called him the evangelist of the anatomists. His followers formed a sect, called "Herophilites" which survived for many years. Probably he merits the general appelation given to him, "Father of Anatomy."

$\mathrm{He}$ is described as having been a tireless investigator and unquestionably the pioneer in dissecting human bodies in public. Initially, he asked Ptolemy for and was granted permission to anatomize the bodies of two executed criminals (Yesko, '40). In all, he may have carefully dissected 200 , and possibly 600 , human specimens, quite a feat for an anatomist in any age; probably few have approached this record. It indicates that he must have devoted himself largely to the pursuit of practical anatomy during his tenure at Alexandria.

One of the charges leveled against Herophilus is that he dissected living humans. The first to accuse him, in this respect, was Celsus (42 B.C.-A.D. 37) in his book, De Medicina. Pertinent facts in the life of this author are unknown. Some describe him as a doctor of medicine, others as an "Encyclopedist," a compiler of existing knowledge. He mentioned that both Herophilus and Erasistratus, several centuries before, had not only dissected the dead but also living criminals received from the prison of the king. These were held to have been opened while breathing in order to observe the inner parts: their position, color, shape, size, arrangement, hardness, softness, smoothness, relations, processes and depressions. Celsus did not believe that dissecting the dead was cruel, as most people said, but rather that it was important and necessary to seek remedies for the innocent people of all future ages by studying the bodies of a few executed criminals, but he drew the line at any policy of vivisection of man. 
The most damaging blow struck against Herophilus in this respect was by Tertullian (A.D. 155-222), one of the most learned fathers of the early Christian Church. He is quoted as follows: "Herophilus, that physician, or rather butcher, who dissected 600 men, in order to find out nature; who hated man, in order to learn the structures of his frame; could not, by these means, come to a more perfect knowledge of his internal structure, since death produces a great change in all the parts, so as to render their appearance after death different from what it was before; especially since they did not die a natural death, but expired amidst all the agonies to which the curiosity of the anatomist was pleased to subject them" (Fisher, 1881a).

In the final analysis, the accusations of Celsus, Tertullian and others, on this question have never been proved by eyewitness accounts and the answer, therefore, will always remain speculative. The evidence seems to be clear that condemned criminals became the first subjects utilized for "anatomies." This established a precedent or stigma to the practice which had subsequent, farreaching psychological effects (Singer, '28).

The most noteworthy studies of Herophilus were made on the brain and he applied names to certain parts of it, some of which are still accepted in translated form, such as the Torcular Herophili, or confluens sinuum. This indicates that he was interested in the vascular system. He classified the brain as the vital center of the nervous system, being the only seat of intelligence. Thus, he took issue with Aristotle, who had localized this function in the heart. He also differentiated sensory and motor nerves and described the ventricular system of the encephalon. Outside of the nervous system, he studied the rhythmic beatings of the heart, named both the first part of the small intestine and the prostate; he also examined the complicated structure of the eye and the female anatomy of the pelvis. In the last field, he was the foremost authority of his time. The liver and spleen were likewise distinguished.

Not much is known of the latter part of the life of Herophilus and nothing of his death. Later writers were familiar with his works largely through the subsequent publications of Galen; only fragments of the originals of Herophilus have survived. 
Of almost equal stature, if not actually so, was Erasistratus $(310-250$ B.C. $)$. It is not known where he was born and little is known of his ancestry. Some historians have stated that he was the grandson of Aristotle. Apparently, he was quite advanced in years when he went to Alexandria to gratify his taste for anatomy. He devoted himself almost exclusively to this study at the expense of his practice.

Erasistratus was a diligent student, who like his contemporary, dissected the human body publicly at the Alexandrian school. He made many important discoveries and evinced a particular interest in the central nervous system. He catalogued both sensory and motor nerves and traced both divisions to the brain and spinal cord.

Besides believing that the cerebrum is the seat of the intellect, he advocated that there is a localization of nervous function there, this being the first theoretical attempt in this direction. Some of his attention, was given to the divisions and cavities of the brain. The soul, he placed in the meninges (Corner, '19). Additional structures which he examined were the valves of the heart, the trachea, which he named, and the lacteals, which he described more fully than Herophilus. Some fourteen books of his were known in medicine but only parts of their textual material have survived in the writings of Aretaeus, Coelius, Aurelianus, Celsus, Discorides, Pliny and others (Fisher, 1881a).

These two renowned individuals were successful in assembling two complete human skeletons which were all that was to survive, anatomically speaking, at the Alexandrian school. For many years and centuries, medical men and students, interested in anatomy, made treks to Alexandria for the purpose of studying these specimens.

There is a gap in our knowledge about the status of anatomy at Alexandria between 250 B.C. and A.D. 200. Galen (A.D. 130-200) stated that the three outstanding anatomists of his time were Marinos, Quintos and Lycos, all of whom were attached to the school of medicine. Marinos (fl. A.D. 130) wrote a text on anatomy which was highly lauded by Galen but it failed to survive (Walsh, '27). Galen also mentioned one Numisianos as being 
his teacher while he was at Alexandria. It is known that anatomy was in a marked state of decay at that time.

Due to the changing of customs and beliefs regarding the sanctity of the human body, liberalism toward the privilege of dissection gradually declined until the end of the 1st Century A.D. and died completely in the middle of the second. The principal reason for this was the Roman invasion and domination of Egypt. Although the Romans seemingly enjoyed and overtly sponsored any amount of gladiatorial bloodshed in their arenas, and all sorts of inhumanities upon living beings, they held that contact with or cutting a corpse was sacrilegious or irreverent. The next to final blow to the great educational and medical institution at Alexandria was struck by Julius Caesar who, in the 1st Century A.D., ordered the library burned. Alexandria never recovered its intellectual supremacy thereafter (Bailey, '11). Because of this act, the originals of almost all the writers of those days were lost. It is said that due to the feminine influence of Cleopatra, Mark Antony later permitted the volumes of the library at Pergamon, in Asia Minor, to be transported and transferred to Alexandria but this was insufficient to restore the prestige of the school. Counteracting the restoration were the rulings of Caracalla (Marcus Aurelius Antonius, A.D. 188-217); who relieved the teachers of their residency privileges, their financial support and the right of making public lectures and holding discussions. This was the death knell; it inaugurated the onset of the Dark Ages. 


\section{[VI]}

\section{CLAUDIUS GALEN (A.D. 130-200) AND HIS INFLUENCE ON ANATOMY}

A

Ithough Galen stands out as one of the greatest medical men of all time, he made very few personal contributions to our knowledge of human anatomy. So important was he, however, that for nearly 1500 years, he ruled the medical world. Many of his words, phrases and thoughts are a part of our medical canon today as well as being current in our daily speech. In an anatomical sense, he was an anachronism, because nowhere throughout the breadth and width of the Roman Empire was he given permission to dissect the human body. Probably no man ever lived who possessed more of an urge to anatomize than he, but this trait had to be sublimated to investigations on lower animals even though he advocated human dissection. Galen's long influence, for which he merits consideration, stems from the fact that he was a prolific writer who published all his findings and medical ideas, because he was followed by a period in which all scientific doors were locked and because he was the only anatomical specialist of note in his time.

Galen, a Greek, lived during the Golden Age of the Roman Empire. He was born in the beautiful Hellenistic city of Pergamon, in Asia Minor, which had been absorbed by the powers of Rome in 133 B.C., about 260 years prior to his birth. His birthplace was almost as well-known, both for its library and as an intellectual center, as its rival, Alexandria, Egypt. Built there, during Galen's youth, was the great Asklepieion, which served as a religious sanctuary, a sanatorium and a place of recreation. It soon became one of the great attractions of the Roman Empire and was ranked as one of the wonders of the world. The medical shrine, a component of the imposing center, influenced Galen 
considerably as he experienced the exaltation of growing up in one of the leading cities of the world.

The parents of Galen were wealthy and educated. His father was an intelligent and kindly man who took a deep interest in his son's education; by contrast, his mother was a high-strung, iras-

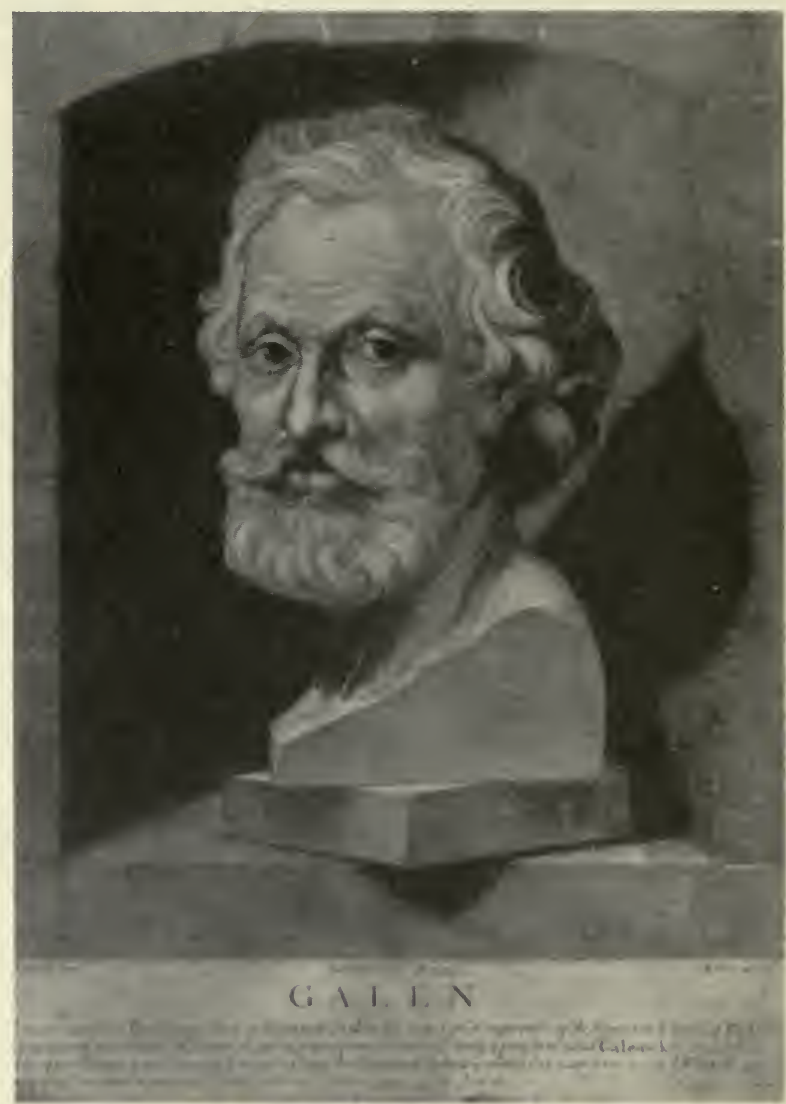

Figure 1. Claudius Galen (A.D. 130-200). Fromiłall, J. M.: The Sack'emup Men. London, Oliver \& Boyd, 1928. By permission of Oliver \& Boyd.

cible and difficult woman. Although the boy studied the various systems of philosophy under the most distinguished teachers, he turned to medicine partly on the advice of his father, who had been inspired in a dream by Asklepios (Fisher, 1881b). It may 
seem odd that Galen's career was determined on the basis of a nighttime phantasy of his father, but phenomena of that sort had much more significance in the lives of the people in those days. Also, it seemed to the youth that there was more certainty in studying nature, and in particular anatomical dissections, rather than the conflicting opinions existing in rhetoric and dialectics. He may have been influenced in this decision by the presence of Satyros, a famous anatomist, who was on an extended visit to Pergamon. Anatomy seemed to bring him back to reality and reach parts of the truth. He felt that in spite of the accomplishments of many brave investigators, the field was still largely virgin, that much needed to be done and that honest labor would be amply rewarded with new discoveries. Galen studied under Satyros for four years and made many private dissections of animals on his father's farm.

He then left his native city and worked with Pelops in Smyrna, now Izmir, Turkey, a harbor of the Roman East, and finally with Numisianos in Corinth, Greece and Alexandria, Egypt. By this time, he was a full-fledged comparative anatomist. Galen reached Alexandria, probably toward the end of A.D. 152 at the age of twenty-two, and remained there for five years. It should be mentioned that he had no recourse to human subjects while at the last city, although it was the main, scientific center of the Roman Empire. The most he saw there in the way of human structure were two skeletons. From these, he probably learned much of his osteology. Later, he advised students to go to Alexandria, to see these two rare specimens, which may have been the only assembled ones existing in the world. The anatomists he mentioned as being present at Alexandira were, Heracleianos, Lycos and Julianos, the last being a very fluent though superficial teacher; Galen classified him with the herd of Thessalian asses.

By the time Galen had reached the age of twenty-eight, he had devoted twelve of them to the study of medicine, chiefly anatomy; he already had written a number of medical treatises. On returning to his native city of Pergamon, he was welcomed and glorified. Between A.D. 158-161, he served as a physician to gladiators, being appointed by the chief priest of the Asklepieion, 
who was also president of the games. During his tenure there, he undoubtedly learned something about living, human structure, by observation of wounded participants who had fought with spears, swords and loaded gloves.

Avoiding local wars, Galen traveled to Rome for the first time at the age of thirty-one (c. A.D. 161-162) and found it in its heyday, a brilliant capital, which offered golden opportunities to Greek physicians. In this city, he ascended to a high, medical rank on the basis of his brilliant elocution, his accurate logic, his profound erudition and his versatility and practical skill (Park, '08). However, he was soon at loggerheads with other practitioners, which may have been caused by his rapid success and his personality traits. He returned to Pergamon at the age of thirty-eight, in A.D. 168, for reasons not entirely clear: either because of diverse threats of assassination to himself or dangers from the bubonic plague, which was then beginning to decimate the Empire. He was called back within a year, by sovereign decree of Marcus Aurelius, to serve as military surgeon for the Roman army which was preparing to fight German invaders from the north. He begged off from this assignment and was destined to remain in Italy until the age of sixty-two (A.D. 169-192) acting as court physician to both Marcus Aurelius and Commodus. Much of his time, during this interval, was spent in literary activity.

In A.D. 192, the Temple of Peace on the Sacred Way, many libraries and bookshops were destroyed by fire in Rome. Most of Galen's writings were lost. Also, the Roman, political climate during the reign of Emperor Commodus (A.D. 180-192) had become intolerable for scholars and philosophers due to his unorthodox antics; he was an athletic brute who regarded himself as the reincarnation of Hercules and he took delight in disporting himself at the Circus Games as both consul and gladiator. His supporters finally became outraged at his activities and they strangled him on January 1st, A.D. 193. Because of these factors, Galen made the decision to return to the quiet of his native city; there he spent the remainder of his life, about eight years, in isolated meditation and writing.

Many of the things that Galen was the first to describe in his his writings, were not necessarily based on pioneering observa- 
tions of his own. As mentioned, human dissections were frowned on in Grecian and Italian cities. This was also true at Alexandria, during the interval of his residence there, because of anatomical decadence. Almost all of the human anatomy he knew, was restricted to the skeleton and what he had seen in superficially wounded gladiators. His knowledge of the soft organs was derived mainly from the bodies of animals: pigs, sheep, oxen, cats, dogs, horses, lions, wolves, at least one elephant, fish, birds, monkeys and apes. The last named was his favorite experimental specie and was apparently fairly common and easy to obtain in his environment.

There was great difficulty and unpleasantness in dissecting in those days. The climate was exceedingly warm during the greater part of the year, making preservation difficult and enhancing the possibility of infection. There seems to be little question but what Galen practiced vivisection without benefit of anesthetizing agents. This was probably done without compunction since callousness toward animals was customary. All anatomists of the time, took it for granted that animal and human bodies were fundamentally alike in their architectural plan and considered it appropriate to examine the bodies of lower specimens in order to understand human anatomy. According to Galen, there were only about five or six men who had devoted themselves to this specialty in the 400 years preceding him. He evaluated Herophilus, Erasistratus and Hippocrates as having been the three greatest physicians before him.

The most important of the anatomical works of Galen, (possibly 500 in number, Green, '51) was De Anatomicis Administrationibus. It referred mostly to the monkey and was written in much detail when considering the inadequacy of the prevailing terminology; it was without illustrations. The portion devoted to the hand was especially good. He made other publications on the veins and arteries, nerves, muscles and bones. These books were not available until the Middle Ages. His physiological experiments on the spinal cord to determine which parts control movement and sensibility were noteworthy.

Although the findings and reports of Galen are praiseworthy and meritorious, they showed some errors: he could not differ- 
entiate nerves and tendons and called the latter "neurons." His description of blood vessels was poor and confusing but these are excusable in the light of the status of anatomy of that day. He did insist, however, that an arteriovenous anastomosis existed (Burr, '31; Warbasse, '35).

Being a sensitive individual, Galen marveled at the sight of the organs, their complexity and beauty. As he was deeply religious, he was inclined to eulogize a divine providence for the creation of the morphological structures he saw. He agreed with Aristotle that nature never makes anything which is superfluous and he was imbued with the idea that form determines function. The latter was in opposition to that taught by Asklepiades who preached that function helps to create the part. This attitude of Galen was highly acceptable and agreeable to the later theologians, whether Christian, Jewish or Moslem; they were all delighted to sing the praises of Galen who extolled the work of god, although he was essentially a pagan. To question his work became a heresy.

Since Galen was one of the great men of anatomy and medicine, what manner of a man was he? He was an only child who remained unmarried throughout his life. On the one hand, he was honest and sincere; on the other, he was egotistic, boastful, quicktempered, hasty in his judgments, lacking in charity, tactless, selfconfidence, complacent and jealous, which makes a rather long list. His mind was facile and neat but he leaned toward theory and classification. His writings, most of which were written in imperial Rome, almost showed too much learning to be appreciated by the rank and file of those in the medical profession. As he aged, his mind became less receptive, more dogmatic and critical.

The style of writing of Galen has not been acclaimed as being outstanding. It was verbose, hairsplitting, quibbling, diffuse, expansive, repetitious and dull which may have been due to the fact that he wrote so much that he failed to take the time to devote to organization. In other words, he was more interested in the content.

In respect to religion, he was a pious pagan who was anxious to keep on good terms with his gods, especially that of medi- 
cine. He accepted many of the superstitions of the day and strongly believed in various forms of divination which he used to make diagnoses of disease in his patients. Thus, he employed both science and magic in his approach to medicine; he did not put his whole faith in reason because he felt there were too many obvious cases of divine providence.

The works of Galen were widely translated and published through the 16th Century from Greek to Latin, Arabic and Hebrew. After the beginning of printing, the fame of Galen increased by leaps and bounds. Many physicians were still swearing by him in the 17 th and even into the 18 th Centuries. This deep and long lasting influence was probably due to manifold causes: his belief that form determines function, that the complexity and beauty of organic structure must be due to a divine providence and his opposition to atomism and evolution. These endeared him to the theologians; they favored Galen over the disliked Epicurus because his facts and methods provided a basis for their religious views. There was thus an emotional factor which gave intensity and fervor to the renown of Galen. He became accepted as an infallible master. Many regarded him as a god and even formed a religious cult for his worship. By some, he was called the "Medical Pope" of the Middle Ages. This accounts for the fact that the anatomical discoveries during the Renaissance which neutralized some of the opinions of Galen, augmented the fanaticism of his defenders. When he is assessed in terms of the medical climate in which he lived or in comparison with the physicians of the 16th and 17 th Centuries, he measures up as one of the outstanding men of his or any other time. It is, therefore, a question as to whether he received a larger share of fame than he truly deserved as a few historians have suggested. It is even possible that he has been greatly underrated in recent years, especially when considering his over-all accomplishments.

After Galen, the practice of dissection, in any form, disappeared, due either to a redoubling of the superstitions against it or to the ignorant apathy of the physicians (Malloch, '26; Prendergast, '30; Sarton, '54). 


\section{[VII]}

\section{ANATOMY IN THE MIDDLE AGES- A.D. 400 to 1400}

\section{A. The Role of the Church}

$\mathrm{T}$ he Middle Ages is defined as that period between the fall of the Roman Empire and the revival of letters, roughly during the chronological interval between A.D. 400 and 1400. The Dark Age is usually applied to the earlier part of this era because of its intellectual stagnation.

As far as anatomy is concerned, the Middle Ages was characterized by being a millennium in which little or no progress was made. The genesis of this status was probably the deterioration and decline of the school of medicine at Alexandria. The two great fires there in the 1 st and 7 th Centuries A.D. destroyed the great collections of medical books which had been assembled. Also militating against the advance of human anatomy, was the prevailing psychology of the people and the hostility of the fathers of the early Christian Church, the latter probably being the more important since their standards had much to do with influencing the thinking of the masses. Human dissection took root in Italy in the 14th Century, for the first time since the Alexandrian period, and from there spread to France and Germany. It began and expanded slowly. The one thing that was needed was legal permission to dissect human material and this had to come from the all-powerful Church which was temporal as well as ecclesiastical. The real authority in medical circles was the writings of Galen, but these had to be rediscovered and translated by the Arabians, particularly by Avicenna (A.D. 980-1037), so they appeared late during the Middle Ages. 
The majority of historians have felt that the Church was in a chronic, anti-dissective mood for many centuries; Walsh ('04) attempted to refute this. Medicine was practiced by religious orders. Ills were regarded as being of divine origin; the human body itself had no standing and was regarded with contempt; it was man's soul, which was considered the highest endowment and its salvation was the priest's main function. If anatomy was studied at all, it was done to understand and interpret the writings in the Bible; it ranked as a pagan science and there was no need to comprehend it. Life itself was judged to be a way station between two eternities, a mere, transitory event. There were some people who primitively believed that after death, sensations disappeared slowly; thus there was no difference in cutting the living or dead. Nevertheless, it was in the last part of this period that the first great step forward was taken in the field of human anatomy (Cruikshank, '06).

\section{B. Psychology of the Times}

Zilborg and Henry ('4l) cited the psychological atmosphere of the people during the Dark Age. The inhabitants of Rome, they said, were leading an extremely tense and emotional life. Barbarians were moving in from the north and east which precipitated a sense of doom. A consciousness of spiritual infirmity grew deeper and the goal became a personal and mystic salvation. The human mind turned to occult philosophy and religious experiences. Original work and thinking almost ceased.

An outstanding characteristic of the Dark Age apparently was the acceptance of magic by many members of the populace. The "possessed" and "witches" came in for considerable attention. The Theodosian Code of A.D. 420 officially prohibited sorcery, classifying it as a crime. Punishing the magician by death became a reality which constituted a marked change from that of the classical period.

The period of the Middle Ages is further described by $\mathrm{Zil}$ borg and Henry ('4l) as being one in which the people were restless, anxiously groping and bewildered, with the cultured beginning to feel out of place. It was an interval of remarkable psychological reactions in which the sword and not the pen reigned; it 
became necessary for science to become primarily monastic where certain medically inclined men and other intellectuals took asylum in the Church. Here, they became compilers of the medical science of the past, especially that of the Greeks.

In the 4 th Century, the influence of the stars on human behavior, began to play an important part in medicine and some of the anatomical figures of the period were decorated with the signs of the zodiac. The early Christian authorities were frightened and puzzled by the whole phenomenon of mental illness which appeared to be increasing and were inclined to assign it to the machinations of the devil.

Hostility to science, in all its forms, became more open, intense and crystallized at the beginning of the 7 th Century. Exorcism and incantations became an indispensable adjunct to even the legitimate practice of medicine. The fragments of what positive knowledge existed became further buried by a fusion of the animistic past of the prehistorics, the mysticism of the early races and the theurgic ceremonialism of an expiring empire. Man became lost as an individual and had to constantly struggle with temptation. It came to be believed that the past contained everything.

By the 13th Century, almost all medical writers and physicians were clerics. Dietetics, herbs and drugs were the chief topics of interest. Scholars were not investigators. Anxiety of the population increased, passions were aroused and soon instruments of torture and burning fagots were introduced. Astrology had definitely become an approach to the problems of medicine.

The man in the street grew more frightened during the 14 th Century. Prevailing were an ecstatic religious tradition, a universal faith in miracles and a cultural monotony. The sorcerer, the heretic and the psychotic began to be perceived as one; psychopathological epidemics increased in number and severity toward the close of this period necessitating recognition by the powers of government.

With this state of affairs existing in the Middle Ages, it is easy to see why human anatomical science became stagnant and failed to progress; everything was against it. Some light, however, 
began to shine through the prevailing clouds during the end of the Middle Ages.

\section{The Arabs and the Reawakening}

The Arabs, a pastoral and nomadic people, noted for their intertribal feuds and conquests, became welded into a unified nation. They settled down, developed a religious enthusiasm and cultivated the arts and peace. Both Bagdad (Iraq) and Cordova (Spain) became centers of learning where the wisdom of the Greeks was studied and expounded with the help of Syrians, Jews and Nestorian Christians. Abstracts, commentaries and treatises were published; all were translations of the work of Hippocrates, Aristotle and Galen, which were written in a language which had become dead. They added little to the sum total of knowledge.

Three men especially played a leading role in this development: Rhazes (850-923), Avicenna (980-1037), and Constantine Africanus (1010-1087). These men were compilers rather than original investigators. Rhazes wrote 226 books. Avicenna wrote one entitled, Book of Canon in Medicine, based on Greek writings which was later translated into Latin. It was more lucidly written than Galen's Anatomy and it overshadowed the latter's authority for four centuries. Constantine translated thirty-seven books, mostly those written by Hippocrates and Galen. These were introduced into the western nations as early as the 11 th Century and constituted the first glimmer of a new dawn; they had much to do with a revival of the ethical Hippocratic spirit so prevalent during the pre-Christian era.

The lack of an investigative spirit constituted the weakest part of Arabian medicine. Original works were not done. The theocratic basis of the Arabian government stood in the way. The Koran was the source and authority for all knowledge; anatomical dissection was forbidden; even drawings and sculpture of the human body were not permitted. It was held that the soul suffered if the body was incised before or after death. They knew Galen's Anatomy and not much more; this lasted until modern times. As late as 1830 , the Arabs had only a pristine knowledge of the subject. 
In summary, it can be said that the main accomplishment of the Arabians was to keep literature and science alive, by translations of Greek and Roman works, during the numerous barbarian invasions, between A.D. 200 and 1300 .

\section{The Universities of the Middle Ages}

Conspicuous, because of the role they played in the revival of human dissection, were the developing university centers, particularly those in Italy. Between A.D. 1200 and 1350, fifteen were opened. With these, scientific controversy and inquiry began to enliven the student's mind. The open door to post-Alexandrian human dissection was legal permission. This was forthcoming from no less a personage than Frederick II, Emperor of Germany and the two Sicilies. Following this, the practice was to be more lasting but attendant with many vicissitudes, drama and struggles when considering the various countries of the world. The important factor was that it gained a firm foothold from which it could progress (Dempster, '34).

\section{The University of Salerno}

The first university to be established in Europe, which taught medicine, was that at Salerno, located about thirty-five miles south of Naples, on the western coast of Italy. Its origin is obscure; the dates which have been given vary between the 7 th and 14 th Centuries. The Benedictine monks of Monte Cassino originally cared for the sick at neighboring Salerno, which was a noted health resort: as a result of their work, a medical school developed in the city. One of the most famous friars was Constantine Africanus, mentioned above, whose works were chiefly translations from Arabian and Greek authors. It was there that Cophon, the younger, wrote De Anatomia Porci which became the standard anatomical text of the institution. Dissections were made of the monkey, pig and bear. Frederick II issued an edict about A.D. 1240 that it was necessary to study anatomy for a year at Salerno or Naples and pass a rigid exam, in order to obtain a license as surgeon: one human subject was allotted every five years. There is vague evidence that the administration ordered human 
dissections be made in the last one-half of the 13th Century. With the rise of other European universities, Salerno began to decline in importance (Corner, '31; Packard, '20).

\section{The University of Bologna}

The University of Bologna became more famous than any other early center because it was here that the first unequivocal post-Alexandrian dissection was made on man. As many as 10,000 students were enrolled by A.D. 1200 and later this reached 20,000 in number (Laurie, 1896). Medical studies started there in the 13th Century (A.D. 1260). To Mondino da Luzzi (1276-1326), goes the credit of being the first to anatomize a human body for perhaps 1,700 years. He is regarded as the "Restorer of Anatomy," as the one who promoted a new enthusiasm for an old practice, and the first European to teach from a cadaver. He definitely forms a link between mediaeval anatomy and Vesalius. As far as is known, that historical event was performed in 1315, in public, and was witnessed by medical students as well as others. The subject was that of an executed criminal, probably a female, and the proceeding had the blessings of the Pope. A second dissection may have been done in the same year. It is said that the anatomist had the choice in deciding the type of execution $/$

Since the body was unpreserved, the dissection naturally had to be hurried. It was accomplished in four readings; a barber did the anatomizing with crude instruments, including a huge cleaverlike knife, while Mondino read from a high professorial chair; thereby, a custom was established which survived for many years; a demonstrator, the third person in the party, pointed out the various structures with a rod. Dogs yelped around the table waiting to devour the pieces of human flesh thrown to them when the professor finished his discourse. No thought, originality, or critical thinking were involved since the only aim was to illustrate Galen. The four sessions, probably one each day, covered the following systems: digestive, respiratory, circulatory and superficial muscles. The dissection was continued into the night.

Not much is known of the personal life of Mondino. He graduated in medicine in A.D. 1290, became Professor of Anat- 


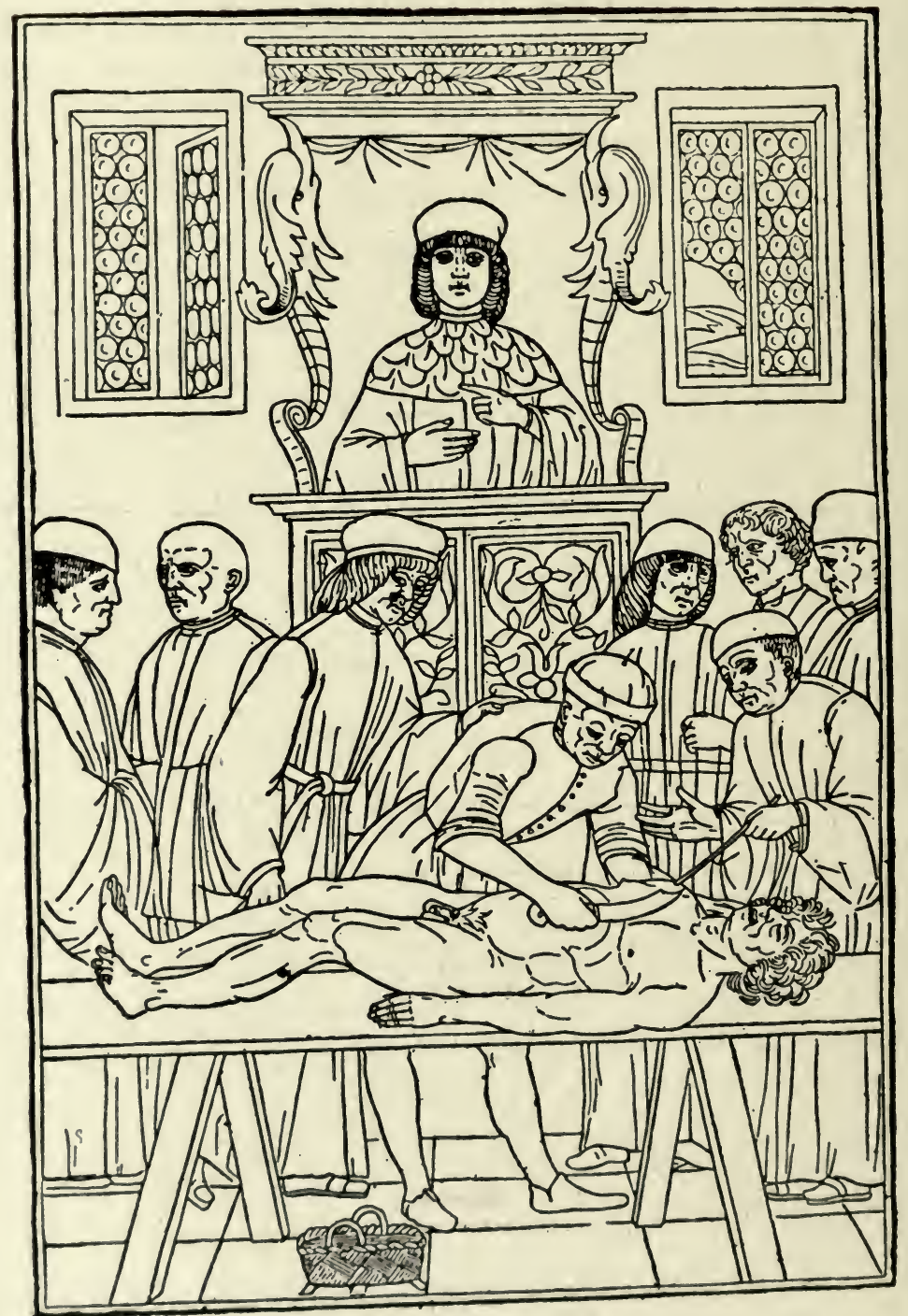

Figure 2. Anatomical demonstration in 1493, being conducted in the manner established by Mondino da Lumi (1276-1326). From Ball, J. M.: Andreas Vesalius the Reformer of Anatomy. St. Louis, Medical Science Press, 1910. 


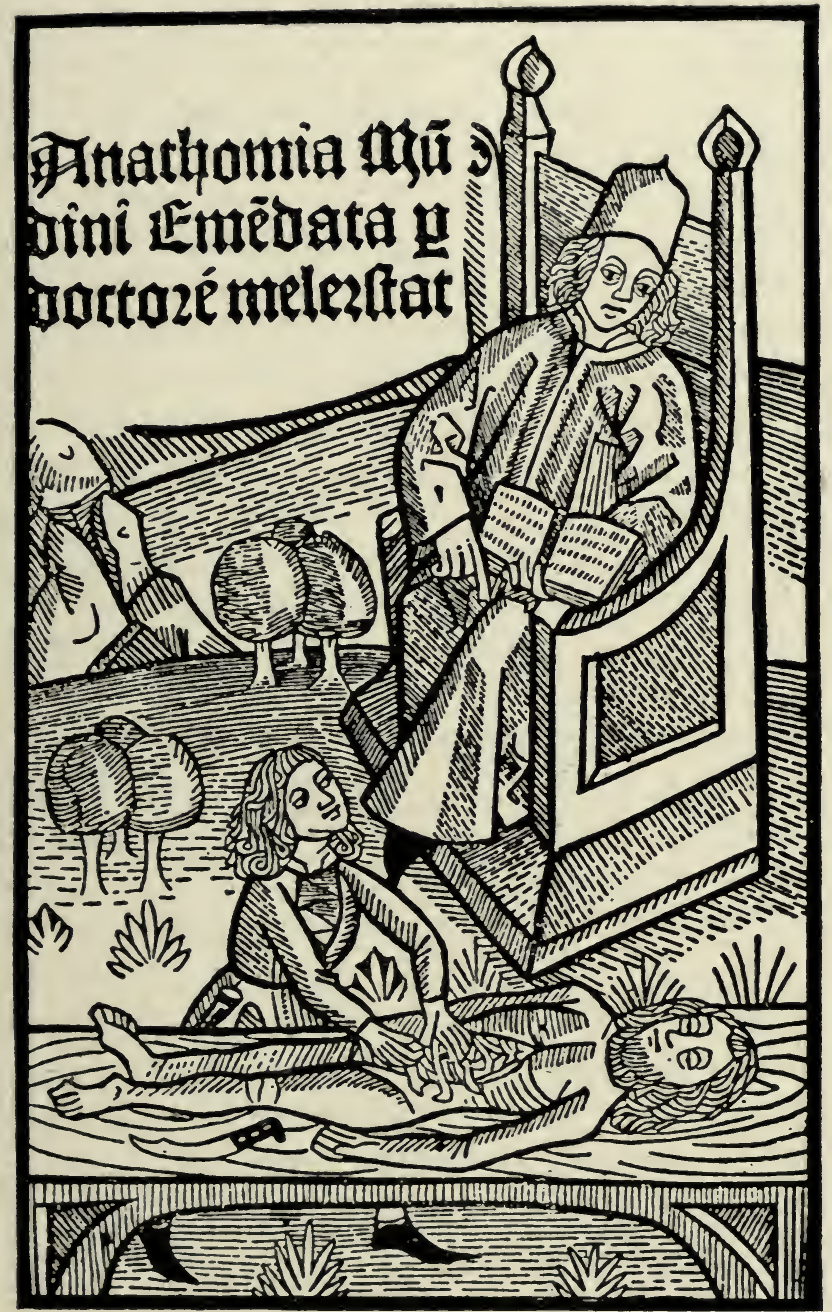

Figure 3. Title page of Mondino's Anatomy, an edition published in 1493 by Melerstat, depicting Mondino and his method of teaching. From Ball, J. M.: Andreas Vesalius the Reformer of Anatomy. St. Louis, Medical Science Press, 1910. 
omy at Bologna in 1306 and died in 1326. At the school, he had two assistants: Otto Agenius Lustralamus and a girl, Alessandra Giliani, both of whom served as prosectors. The latter was generally skillful but particularly so in dissecting arteries and veins. She experimented with and becaine an expert at injecting these vessels with colored pigments.

In 1316, Mondino published a compendium, De Omnibus Humani Corporis Interioribus Membris Anathomia, which was only forty-four pages in length. It offered nothing new over Galen or Avicenna and was apparently copied from them. Nevertheless, $\checkmark$ it went through twenty-three editions between A.D. 1478 and 1580 and was widely used in Italy and Germany. In this text, his language is that of one who dissected frequently; he spoke of making many experimental dissections. Anatomy at that time, was apparently cultivated only as an appendage to surgery.

The first sign of rebellion, on the part of the medical profession, against the restrictions and stigma placed on the supply of cadavers, made its appearance shortly after the pioneering anat/omy of Mondino (A.D. 1315). In 1319, four students were apprehended and accused of resurrecting the body of a criminal from its grave and transporting it to the school to be used for dissection. There is no account of the final disposition of this case.

Mondino's radical method of teaching human anatomy started a movement in Italy, which was to put this country in the forefront as a medical center. As the word spread of the innovation, medical men, teachers and students from Italy and other countries journeyed to the University of Bologna for purposes of study $\sqrt{ }$ (Dempster, '34; Pilcher, '06).

\section{The University of Montpellier}

This institution was founded in A.D. 1180 and rivaled the school of Salemo in the quality of its instruction and research. By order of a Papal Bull, a medical department was established in 1220 and it now ranks as the oldest in the world. Today, the faculty of medicine occupies the edifices of the Benedictine Abbey founded by Urban V in 1364. Jewish and Arabian physicians had 
much to do with its rise and they favored Hippocratic methods of teaching. The University of Montpellier was not far behind Bologna in respect to pioneering in human dissection. When Henry de Mondeville (1260-1320) returned to Montpellier, after attending classes at Bologna, there was no statute permitting restricted anatomies. He is said to have utilized a human skull for teaching purposes; otherwise, he used charts. His surgical manuscript published in 1314 contained crude, anatomical pictures. It was in 1340 that the first ordinance was passed in France permitting human dissection once every five years, the time interval being debatable, for two years is also mentioned. The chronological gap was evidently lowered in 1376 by another decree allowing an annual dissection of a criminal. Apparently, the proper authorities did not make delivery of such so the faculty, in 1377 , requested that this be done. Dissections are reported being performed there in 1377, 1396 and 1446 (Cooper, '30).

\section{General Information on Other Universities}

There is historical evidence that dissection was legalized in certain other cities of Italy, Spain, and Germany during the 14th Century, but little is known as to how much was performed. At the most, it is possible that very few humans were anatomized because of the standards involved and the general reaction against it. Three factors stood out: one was that the subjects in each country had to be those of executed criminals, which attached a stigma to the act; the second was that the proceedings had to be conducted in public, which publicized the event; the third was that few specimens were turned over to the proper authorities, namely the professors of anatomy or surgery. In the last respect, the most generous law permitted one subject per annum; the least, one every five years.

The following list consists of other cities in Europe and the date human dissection was started in the 14th Century: Venice, 1308; Prague, 1347; Naples 1365; Florence, 1387; and Lerida, 1395. 


\section{[VIII]}

\section{ANATOMY DURING THE EUROPEAN RENAISSANCE-A.D. 1350 to 1650}

\section{A. General Characteristics of the Period}

$\mathrm{I}_{\mathrm{n}}$ he encyclopedic literature pertaining to the period of the Renaissance, roughly between A.D. 1350 and 1650 , not much is mentioned in respect to the accomplishments of medicine; it is a field which is not specifically highlighted. Nevertheless, as far as human anatomy is concerned, it represents probably one of the most important and spectacular periods in the history of the subject. This is because pioneers dared to come to grips with the superstitions and hostilities of the populace, to make accurate observations on the structure of the human body and to report what they saw at the risk of censure and social ostracism.

At this time, when the mediaeval pattern was dissolving, certain men became interested in the physical world, in the life of sensation and concrete experience, in the character and opportunities offered the individual. Whether a man was a member of a religious, political or social order began to carry less weight. Some of the outstanding events of this age were the following: rapid growth of commerce and travel, development of cities and industry, and increase in wealth. Making its appearance, was a new, rich and leisured urban class that devoted much of its energy to the pursuit of worldly culture. Class distinctions began to break down and a new, tireless curiosity directed toward secular knowledge became evident. The temporal power of the church was reduced and its spiritual authority was split by the rise of Protestantism.

Exploration was the key word of the era. The boundaries of the known world were extended by great voyages of discovery 
to the west, beginning in 1492 with Columbus; these created vast new sources of wealth and power and stimulated the rise of nationalism and the formation of huge empires. The revival of interest in the culture of antiquity gathered further momentum when the classical scholars of Constantinople fled westward after the fall of that great city in 1453. This brought new minds to Europe, with different ideas, and it provided a potent impulse to the productive imagination of Renaissance man. The intellectual and artistic response was everywhere about the same. First, there was a period of critical scholarship (Humanism), then a time of magnificent artistic and literary flowering, followed by a terminal phase. In the last, the science and criticism of the developing age of reason began to overshadow the creative power of the Renaissance. It was particularly the Italians of the period who influenced the surrounding countries of France, Spain, Germany, the Netherlands and England.

Toward the end of the Renaissance, cultural decay became evident in various countries. This was due to the growth of nationalism in Spain, France and England and their expansion into world powers. Such a development reduced the commercial importance of the Italian cities which had been prosperous. Germany, with her feudal states, was severed by the religious disagreements revolving around the Reformation and the Thirty Years War. Elsewhere the creative energy of the Renaissance experienced a more gradual decline.

\section{B. The Mind of the Renaissance}

The picture which is painted of the minds of the Renaissance by medical psychologists (Zilborg and Henry, '41) is as follows: According to them, in the early part of the period, the Christian world was in a bad state, suffering from the cumulative effects of centuries of superstition.

Belief in witches was widespread, the average mental stage being about as low as some of the primitive races existing today; in this respect, many physicians believed in them. Two Dominican brothers, Johann Sprenger and Heinrich Kraemer, as leaders of a movement to exterminate them, wrote a book, The Witches Hammer, described as one of the most horrible documents of that 
period. By A.D. 1800, it had gone through nineteen editions. In the year 1484, Pope Innocent VIII issued a Bull, supported by Maximilian, King of Rome, naming these two men Inquisitors. Almost all mentally sick were soon classified as sorcerers and life was made difficult for them. No man, woman or child was safe. During the reign of Francis I, King of France, severe justice was handed out to 100,000 persons. The last witch to be killed in Germany was Anne Marie Schwagelin, March 30, 1775; she was decapitated.

At the beginning of the Renaissance, the Black Plague swept Europe and was such that it created a psychological effect on the masses. It made man realize that he was even more frail than the mystics painted him. Social consciousness began to stir and certain individuals began to become puzzled and fascinated with what went on in the mind and what emotions were.

It wasn't until the 16th Century that things began to change. In this period, the individual was born, but he was "restless, selfassertive, self-contradictory, independent, fearless, quixotic and reckless" (Zilborg and Henry, '41). Many became skeptics and it was they who made valuable contributions to European civilization.

What needed to be done, apparently, was to unshackle the mind which had been kidnapped by theologists and philosophers. Although the Renaissance discovered man as a person and was beginning to think of him and nature as one, nevertheless he continued to remain uncertain of himself. This was attested to by the fact that the mentally sick abounded in cities and villages during the early 1600's. They occupied prisons, cellars and wandered around the streets and highways either to the amusement or horror of the populace. The medical profession now generally accepted the fact that it was disease of the brain which was responsible for psychiatric conditions. However, Thomas Willis (A.D. 1621-1675), ranked as one of the greatest neuroanatomists and physicians of his day, believed in devils and in the value of severe treatment of the psychiatric. He was not averse to employing torture and torment as therapeutic methods. By this approach, he believed that the mind could be induced to give up its abnormalities, its wild ideas, and become meek and orderly. 


\section{Status of Human Dissection on the Continent}

During the Renaissance, more and more countries became interested and involved in human anatomy. In each, the factors militating against dissection were religious belief in a soul, superstition, faith in Galen and Avicenna, repugnancy of society and the lack of proper methods to preserve the body. For many years and even centuries, the standards of anatomizing remained identical everywhere. Before Vesalius, neither the teacher nor student touched the cadaver. After Mondino, dissections became more elaborate and ceremonious. The spiritual factor was not forgotten since special rites were conferred upon the condemned before execution to atone for the deed about to be performed upon his body. High ranking officials and privileged citizens were sent special invitations to attend. After all guests had taken their seats, the Papal writ permitting the dissection was read aloud and the seal of the university was offered to the corpse.

Prior to the actual performance of the dissection, the subject's head was removed because there was a prejudice against exposing the brain, which according to the Christian concept was thought to be the seat of the soul. During the evening following the completion of a dissection, which was perfunctory, a festive celebration was held with a banquet, concert and theatrical performance. Many of the title pages of books written during the period, were decorated with ornamental figures depicting both the gayety of the dissection itself and the unmistakable finery of the time.

The study of human anatomy, under the foregoing standards, reached its peak in Italy in the last half of the 16th Century. Magnificent, anatomical theatres were built to accommodate the thousands of students who had become interested in the subject; those at the Universities of Bologna and Padua were particularly outstanding and beautiful. Other countries followed suit: the Netherlands matched the standards in the Italian schools whereas less ornateness was characteristic in France, Germany and England.

In respect to suitable legalization of human dissection, which would provide an ample number of cadavers for the teaching of anatomy, the Continental countries fared better than England, Scotland and Ireland. America had not developed sufficiently to be considered but later it was to experience the same difficulties. 


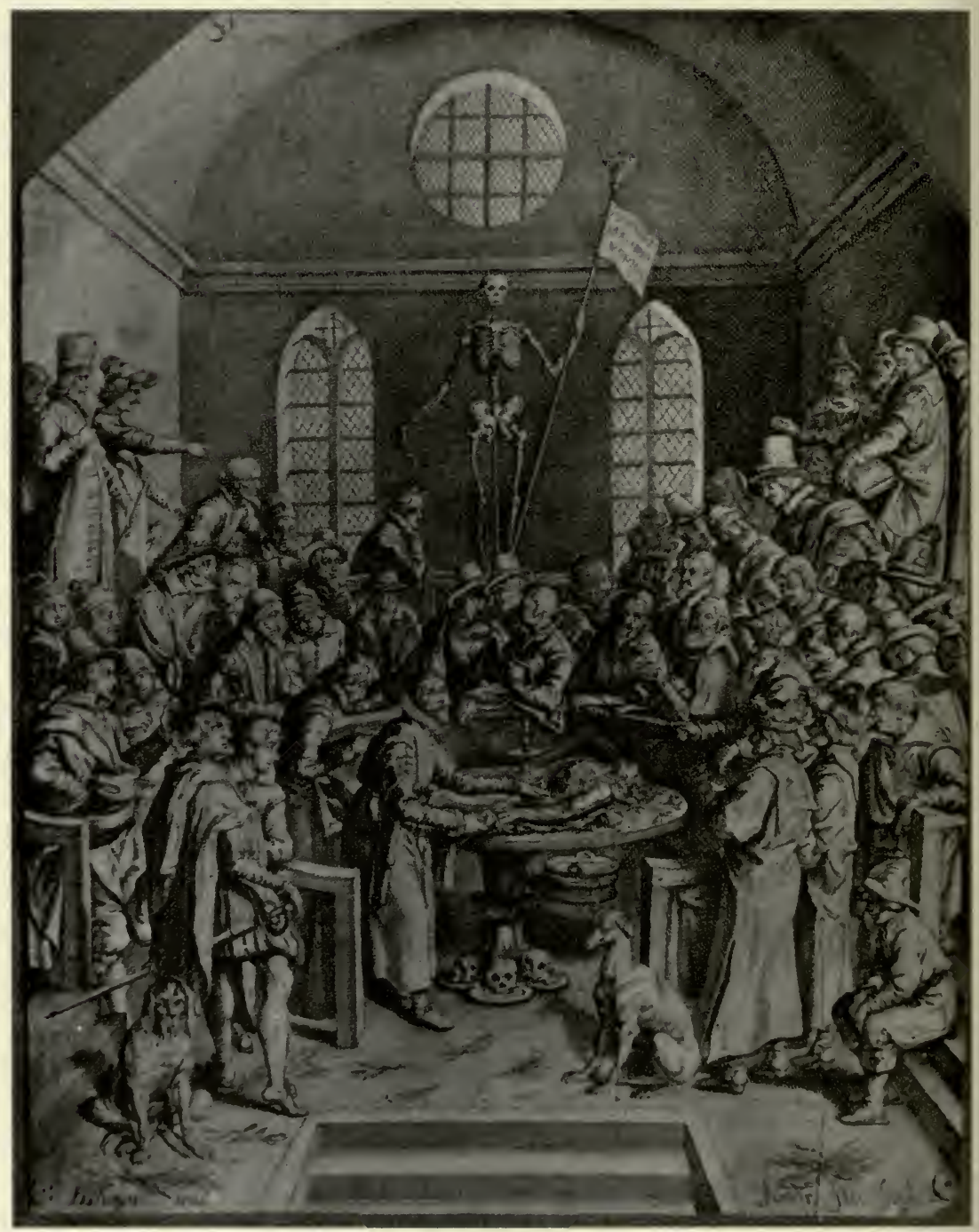

Figure 4. Andreas Stog's Engraving of Pieter Paaw's Theatre of Anatomy, 1589. From Ball, J. M.: The Sack-em-up Men. London, Oliver \& Boyd, 1928. By permission of Oliver \& Boyd. 
From the very beginning in the history of human dissection, two forces were at work and were to remain so indefinitely. One consisted of a minority group of physicians and students who were subjected to standards and who wanted to dissect. The other was a larger, non-medical class, influenced by superstition and the Church, who were opposed to it. It was in the European nations, the British Isles excluded, where more frictionless systems were evolved.

In France, cadavers were obtained from civil hospitals, prisons and almshouses after remaining unclaimed for an interval of twenty-four hours.

The bodies which were available in Germany, in part, were those who had died in prisons, penitentiaries or committed suicide. They were protected to the extent that friends could provide ordinary burial rites if they paid a certain sum to the funds of the school. Other sources included those who had died as paupers, poor people who had been supported at public cost, those executed and public women. This system functioned so that there was an ample supply of cadavers for anatomic purposes even though the law was not rigorously carried out; exhumation was largely unknown.

Unclaimed bodies were used for dissection in neighboring Austria. They were judged to be such when not claimed fortyeight hours after death. Most activity centered in Vienna where cadavers came from the general hospital. The supply was sufficient and there was no recourse to illegal sources.

In Italy, the governmental regulations were even more liberal: all persons who died in hospitals were automatically given up for dissection provided no friend stepped forth with the money necessary to defray funeral expenses. Usually, this source was sufficient to supply all needs. If not, subjects could be obtained from the "deposit" of paupers who died and were buried at public expense. In every parish church in Italy, such specimens were removed either to the dissecting-room or to a pauper burial ground outside of the town. Body snatching was virtually unknown. 


\section{The Church and Dissection during the Renaissance}

One of the outstanding features of the Renaissance is that human dissection was tolerated at all. This again brings up the question of the stand taken by the Church, which was both ecclesiastical and temporal in power. It is probable that the populace was more hostile to it than the theological authorities. The Popes did not actually try to prevent it as evidenced by the fact that permission was given to Italian and other European schools which were under theurgic control. There was no teaching that the corpse was sacred or that using the scalpel was sacrilegious. Walsh ('04) staunchly defended this attitude believing that the Church was deeply interested in medicine and encouraged legal regulation of it as well as the establishment of medical schools.

It was Pope Sixtus IV (A.D. 1414-1484), who had been a student at Padua and Bologna, who gave permission to open human bodies. This undoubtedly promoted the development of anatomy during the latter part of the 15 th Century and established a precedent. Pope Clement VII (1478-1534) also sanctioned this. Under the supervision of these two ecclesiastical authorities, Conditions for anatomical study improved and later Rome became somewhat of an anatomical center. Emperor Charles V (15001558) asked the faculty at Salamanca for its opinion regarding dissection; the teachers replied that they thought it was permissible according to the edicts of the Catholic Church.

\section{Role of Artists in Anatomical Renaissance}

The influence of the artist, in respect to anatomy, during the early stages of the Renaissance cannot be overestimated. It was he who was primarily interested in muscles, bodily action and posture and he made every effort to dissect when and where he could. Quite a lengthy list of the painters known to have been involved in human dissection could be presented. Among them can be mentioned such names as Leonardo da Vinci (1452-1519), Michelangelo (1475-1564), Albrecht Dürer (1471-1519), and Titian (Tiziano Vecellio, 1477-1576). There is some question as to whether Donatello (Donato di Niccolo di Betto Bardi, 13861466) or Antonio Pollaiuolo (1429-1498) was the first artist to actually dissect a human subject. The former, in a painting en- 
titled Miser's Heart, portrayed a public dissection, with surgeons looking into the cadaver's chest. He was the teacher of Pollaiuolo and was judged to have the best anatomical background of his contemporaries; this was obtained by observations of his own dissections. Michelangelo spent sixteen years in anatomical studies on animals and man which almost ruined his health; it is claimed that he practiced vivisection. Andrea Verrocchio (1435-1488) performed fifty anatomies during his lifetime and made many figures in wax, plaster and bronze.

The historical evidence indicates that between 1400 and 1543 , more anatomies were probably made by artists than by anatomists, although both worked together when they could. Some authors state that a rivalry existed between them. Apparently, the observations made by the artists at the public demonstrations were insufficient to satisfy their curiosities and needs which led them to consider ways and means to proceed on their own.

Dissections by artists were carried out either in hospitals with the sanction and supervision of the superintendents therein, or in dead houses attached to the churches, with the approval of the Pope. The privilege to dissect was especially important to Michelangelo; he refused to sculpture figures for the Church of the Holy Ghost, at Florence, unless the monastic superior would pay him in cadavers taken from a neighboring cemetery. This arrangement apparently reached the ears of the populace who reacted unfavorably; the word spread that he was willing to crucify a man and let him die in order to depict Christ on the cross. There is thus evidence that the practice of resurrecting human bodies, which was short-lived, occurred in Italy, during the first part of the 16th Century and that dissection was done surreptitiously behind closed doors with the approval of the Church.

It is possible that the painters, especially those who had established distinguished reputations had less difficulty in obtaining human cadavers than did the anatomists and physicians. More hostility may have been directed toward the medics because they had to associate themselves with the bodies of executed criminals and because medicine lagged behind progress in art; as a whole, they were not held in very high repute. Some of the artists, such as Leonardo da Vinci, were noted for their charm, graciousness 
and personality, and experienced little trouble in opening doors and channels barred to other persons.

The minds of the artists were untrammeled by the traditional bias revolving around anatomy; they were men who were enthusiastic, trained in making careful visual observations, anxious both to perform dissections and draw accurate illustrations. It is possible that the practice was offensive to some but, nevertheless, they were greatly responsible for advancing the study of all forms of human anatomy. Their observations, revealed through their drawings, paintings and statues, had scientific exactitude and introduced a fresh approach. It was they who taught the public the importance of anatomy through the realism of their work. Undoubtedly, they took more than a casual interest in human anatomy and through their collective effort more naturalism was attained in their creative art.

Of all the artist-anatomists of the Renaissance period, it was Leonardo da Vinci (1452-1519) who was the most outstanding. In terms of the evolution of anatomy, it was he who was the leader in the transition from the mediaeval to the modern world. In 1516, three years before his death, at the age of sixty-four, he made the remark that he had dissected more than 100 human subjects, many of them at Florence. During his lifetime, he made 779 anatomical drawings, on 235 sheets. Some lacked systematic arrangement. This is evidence that he studied anatomy voraciously and observed keenly; in fact, this work was done basically in preparation for an anatomical treatise which he wished to write. No less an authority than William Hunter classified him as the greatest anatomist of his era.

From the standpoint of da Vinci's interest in anatomy, which began at the age of seventeen, his life can be divided into three periods: those intervals spent successively in Florence, Milan and Rome. He accomplished most in Milan, where he resided for thirty-one years, dissecting when the opportunity presented itself.

During and after serving an apprenticeship under Verrocchio, the artist, in Florence, he studied flayed bodies, that is, ones from which the skin had been totally removed, permitting examination of the superficial muscles. His notes tell of anatomizing at the Santa Maria Nuova hospital in Florence, where he spent thirteen 
years, between the ages of seventeen and thirty. It was there he decided that, in order to understand the human body more fully, it was necessary to delve deeper into its structures, to expose and

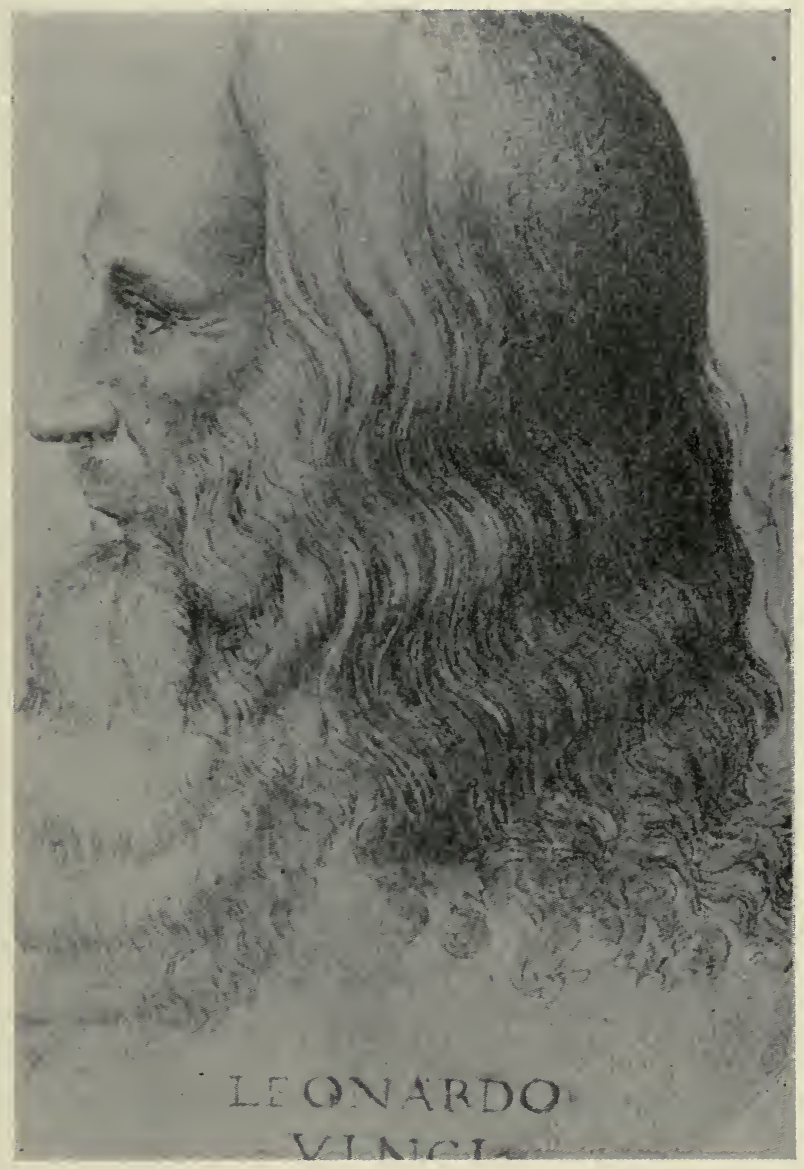

Figure 5. Leonardo da Vinci (1452-1519). From Garrison, F. H.: $A n$ Introduction to the History of Medicine, Fourth edition. W. B. Saunders Company, Philadelphia, 1929. By permission of W. B. Saunders Company.

examine all parts down to the bones. Therefore, he went further into the anatomical secrets of man because his interests were more than artistic. With broad perspective, he made comparisons between the human male and female and the feet of various ani- 
mals, including man; he also noted the changes in structure from birth to old age.

When Verrocchio, his master, left Florence for Venice in 1482, Leonardo departed for Milan, at the request of Lorenzo de Medici. There, he apparently obtained all the material he needed either at the Ospedale Maggiori or Academia dei Fisici. What he complained of most, was lack of time to pursue the art of dissection.

While at Milan, Leonardo came into contact, for a short time, with a young Professor of Anatomy at the University of Pavia, Marc Antonio della Torre (A.D. 1478-1511), who was anxious to write a treatise on anatomy. Da Vinci sketched from the dissections made by the anatomist and himself with the intention of using them in the publication. Some were repeated a number of times to get the picture desired and to account for variations. The untimely death of della Torre, from the bubonic plague, prevented this prearranged goal.

Leonardo fared less well in his anatomical pursuits at Rome, to which city he migrated in 1513, at the age of sixty-one. He performed dissections for a short period but, for the first time, his notes indicate, he complained of lack of material. He encountered opposition from Pope Leo X who denied him admission to the city hospitals. His anatomical investigations led to his being suspected; sacrilegious motives were imputed; this accounts for the fact that the last five years of his existence were sterile in this field.

Leonardo believed unequivocally in the value of dissection to learn human anatomy; he advocated it strongly and personally exhibited great zeal in its pursuit and was able to inspire those around him. He observed that the anatomists of his time showed, from their behavior at the cadlaver table, that they revered the human body, whereas others in society were more interested in destroying it. At first, he utilized the text of Avicenna as an aid, but later abandoned it as well as all authority; he became an original investigator and probed ever more decply into the structure of man.

Like his contemporaries, he did not find dissecting easy to perform: there were no methods available to artificially preserve 
the body. In the warm climate of Italy, they decomposed easily and he had to conduct his anatomies during nocturnal hours. However, he undoubtedly found this task more pleasant and less offensive than some of his fellow-artists. He made comments in his notebook that a dry, thin body of an aged person was much easier to dissect than that of a fat, succulent, young one.

What Leonardo was principally interested in was the proportions of the human body since he was, by temperament, an artist. He related structure and function and was probably the first to think in terms of cross-sectional anatomy. He paid a good deal of attention to the composition of the eye since he regarded it as the window of the soul. The vessels also attracted him, and with further study, he might have discovered the circulation of the blood.

When he died, 120 volumes of notebooks were left to his pupil, Francesco Melzi. They remained in the family of this individual for some time and eventually many became scattered and lost. Napoleon took some of them from Milan to Paris. Currently, twelve to fourteen books survive in England and Italy. The largest proportion of these are preserved in. Windsor Castle where they were rediscovered and publicized by William Hunter in 1784 (Belt, '55; Dempster, '34; McMurrich, '30; Streeter, '30).

\section{Universities of the Renaissance}

a. The University of Bologna. At the beginning of the humanist movement, when there was an increasing demand for a knowledge of human structure, the University of Bologna thrived for a while as a center for anatomical teaching. At first, the academic course was included under the division of Arts.

In 1405, it became necessary for the professor of anatomy to obtain a license from the Rector of the University in order to acquire legal possession of a body before any anatomies could be performed. Both teachers and students, however, were prohibited from dissecting; this had to be done by a barber. Only third year pupils were allowed to witness the demonstrations.

In 1410, the city of Bologna assumed the burden of paying the salary of professors; this inaugurated official control of uni- 
versities by the Italian states. There are statements in the literature that, even at this early date, students organized expeditions to snatch bodies from graves. When anatomies were held, nothing more was done than to try to verify the ancient authors, particularly Galen. In the year of 1410, Pietro d'Argellata, Professor of Anatomy at Bologna, had the unusual distinction of examining the body of Pope Alexander $V$ who had died suddenly in Bologna (Singer, '25). This may be the first instance where the corpse of a high-ranking authority of the Church was autopsied by an anatomist. Before the building of the beautiful, anatomical theatres, it seems that the dissections were performed in hidden rooms, the procedure being kept as secret as possible.

It is known that in 1442, the Rector of the University of Bologna permitted two bodies per year to be used for dissective purposes; these were a male and female, but they had to be obtained from an area located at least thirty miles outside of the city. It wasn't until 1561, about 120 years later, that this ruling was revised so that cadavers could be procured within urban limits. Alessandro Achillini, Professor of Philosophy and Medicine (A.D. 1463-1525), is described as dissecting by himself in 1490 , which would have been an innovation at Bologna.

Anatomical study reached its peak at the University of Bologna during the last half of the 16th Century when thousands of students were in attendance. It then began to wane in prestige. Some of the decline may have been due to difficulty in obtaining an adequate supply of subjects. Cortesius, Professor of Anatomy, for example, complained in the early 17 th Century, that he had received only two cadavers in twenty-four years whereas he had expected one annually. In the hope of neutralizing this dearth, Pope Benedict XIV (1675-1758), issued a decree declaring that the bodies of all those dying in the hospitals of Bologna be made available for dissection.

It seems permissible to conclude the following in respect to the University of Bologna: that careful dissections were performed and witnessed by many students, numbering perhaps in the thousands; that the Popes did not prohibit the practice but rather encouraged it; that there was no teaching of the sacredness of 
the corpse and that barbers were not punished for performing their duties (Bailey, '11; Franchini, '32; McMurrich, '30).

b. The University of Padua. This university was another which quickly rose to anatomical prominence. Padua was incorporated into the Republic of Venice in 1405 and was probably not so closely supervised by the Church as the school at Bologna. Dissection was officially recognized there in 1429, when a male criminal was anatomized. Bertapaglia, a surgeon of the period, tells of attending similar events in 1439 and 1440. Montagnana witnessed fourteen post-mortems in Padua in the year of 1444. A magnificent anatomical theatre, which became widely known, was built in 1446, some say at the personal expense of Fabricius (1537-1617), others on the general basis of raising funds which were quickly subscribed. Harvey was later to study human anatomy in this building. It is definitely known that demonstrations were made in 1520, 1532, 1536 and 1537.

The most famous investigator to teach there was Andreas Vesalius (1514-1564) whose story will be taken up separately. He was succeeded in 1544, by Realdus Columbus who anatomized as many as fourteen bodies in a twelve month period; he also published. a treatise on the lesser circulation, De Re Anatomica, in 1559 , the year of his death. He believed the blood was aerated in the lungs and that there were no pores in the heart septum. Columbus was followed by Gabriel Fallopius (1523-1562). It was at this time that anatomists began to dissect on their own, taking over this duty from the barbers (Ball, '10).

c. The University of Montpellier. In France, the University of Montpellier was without question the pioneer in anatomical studies. Permission was granted in 1376, by King Louis D'Anjou to perform a dissection on the body of one executed criminal annually. This was about 200 years before Sylvius introduced the art in Paris. The citizens of Montpellier had shown themselves to be freer, broader and more independent in thought than the population of Paris.

The information on succeeding events in Montpellier is fragmentary. Chronologically, it is as follows: in 1532, Rabelais, a noted French physician, satirist and humorist, is known to have dissected there. Between 1552 and 1557, only five or six official 
demonstrations were given by anatomy professors according to a diary by Felix Platter; he was a medical student whose journal reported that he joined a secret band of grave robbers in his second year at Montpellier in order to get more material for self-

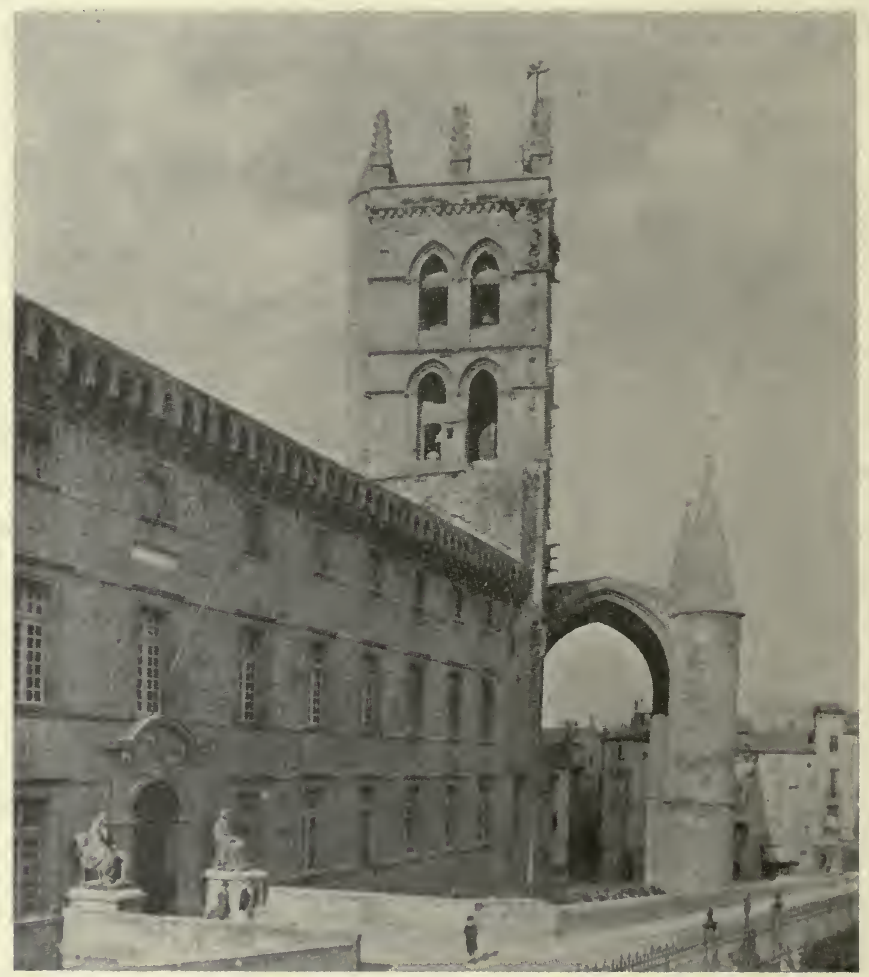

Figure 6. Entrance to the Medical School of Montpellier. The building dates from 1364. Wrom Castiglioni, A.: 'A History of Medicine. Translated and edited by E. B. Krumbhaar. New York, Knopf, first edition, 1941; second revised and enlarged edition, 1947. By permission of Knopf.

instruction. An anatomical theatre was built by Professor Rondelet in 1556; he has been accused of dissecting the body of his dead son before his classes, indicating possibly a scarcity of material.

A chair in anatomy and botany at Montpellier was created by, edict of Henry IV, King of France (1553-1610). Richer de 
Belleval was appointed to this post but refused to give any lectures in anatomy in spite of the protests of his colleagues (MacCallum, '08).

d. The University of Paris: Sylvius and Servetus. No exact date can be ascribed to the founding of the University of Paris. In 1483, its faculty decreed that a knowledge of anatomy was required for a $\mathrm{MB}$, but human dissections were performed prior to that date. Baker ('09) and Singer ('25) both stated that a public anatomical demonstration was made as early as 1478 .

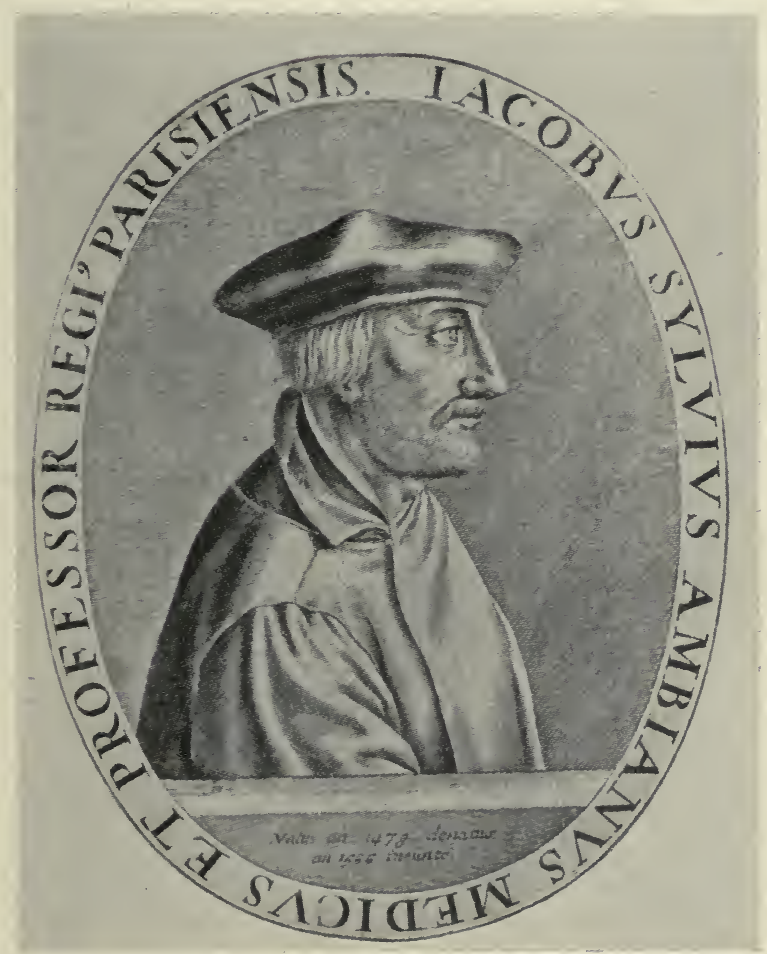

Figure 7. Jacques Dubois (Sylvius) (1478-1555). From X'Garrison, F. H.: An Introduction to the History of Medicine, Fourth edition. Philadelphia, W. B. Saunders Company, 1929. By permission of W. B. Saunders Company.

One of the early anatomists to make news at the University of Paris and elsewhere was Jacobus Sylvius (Jacques Dubois, 14781555). His personality, plus the fact that he taught students who 
wrote about him, had much to do with the spread of his name. He was a man who apparently could arouse the emotions of people around him in the direction of antipathy. Vesalius accused him of entering the profession for the sole purpose of making money. Historians credit him with being the first in Paris to dissect man.

Sylvius was born in Louvilly, near Amiens, the son of a weaver. He showed ability in languages early in his educational career and became interested in the human body through his studies of Galen and Hippocrates. Too poverty stricken to work for a medical degree, he began teaching students about the human body with a great deal of success, as far as numbers were concerned. However, the University of Paris forbade him to carry on this program so he went to Montpellier, where he managed somehow to obtain a medical degree; apparently, he dissected there when he could. When he returned to Paris, he already had established a reputation as a teacher; he reopened his classes at Tregiurer and soon became famous. He attracted students reaching 400 to 500 per class. Like his predecessors, he taught anatomy from the chair and saw the structures of the body through the eyes of Galen, whom he idolized and glorified. He subordinated all of his discoveries to him. When forced to admit that some of Galen's statements were obviously incorrect, he supplied a ready answer, namely that the body had changed in its organization during the 1400 years since the time of the famous Greek. Nevertheless, he recommended and encouraged dissection as the best way to learn and digest anatomy.

Among the students who were attracted to the classes of Sylvius, were the following: Vesalius, Servetus, Stephanus, Gennarus and Vulpinus. The first studied under him for three years, during which he laid the foundation for his famous Fabrica. This would not have been possible unless he had been given the liberty of dissecting and observing the structure of the human body at his pleasure. Vesalius was very critical of Sylvius, accusing him, among other things, of providing insufficient bodies for use in his anatomical theatre.

Sylvius worked under adverse conditions which were either created by himself or were due to circumstances beyond his con- 
trol. In the winter time, he endured the cold without benefit of fire; his method was to counteract this by means of violent exercise. He had a reputation among his pupils of being miserly and poverty stricken.

In physical appearance, Sylvius was short, square-set and had an abundant head of hair; his voice was harsh and unpleasant. He remained unmarried and consequently had no one to care for but himself. His debits, personality-wise, according to his associates were the following: he was intolerant, avaricious, disagreeable, violent, rough, rude, vindictive and possessive of a quick temper. He was jealous of the fame of others. His pupils jeered him for these traits. On the credit side, were a quick intelligence, tenacious memory, eloquence, industry and teaching ability.

Baker ('09) believed that many authors in writing the history of Sylvius have been unjust. He was the first to dissect the human cadaver in Paris. A great service was rendered by him because he revived, popularized and gave anatomy renown. Without having been cast in the shadow of the anatomical light emanated by his great pupil, Vesalius, he might have been regarded as the chief anatomist of his age. Because of his bigoted idolization of Galen, whose teachings were gospel, he came off second best in his arguments with Vesalius whom he called insane, mendacious, vile and impudent. He did, however, improve on Galen's terminology and distinguished between voluntary and involuntary muscles (Montagu, '53).

Sylvius died at the age of seventy-seven years and was buried unbefittingly in the Cemetery of Poor Scholars with an inscription on a marker of his grave written by one of his former pupils (Ball, '10):

Sylvius lies here, who never gave anything for nothing:

Being dead, he even grieves that you read these lines for nothing!

Probably, more has been written about Michael Servetus (1511-1553) than any other medical man of the Renaissance period. Bainton ('32) gives a bibliographic list of 156 articles and books which he was able to find up to 1932. This is due 
to the fact that the events in his life were ultra-dramatic and such that he became a martyr for his religious convictions. It is a question as to whether Servetus was first a theologian and then a physician or vice versa. He is included with the discussion of the University of Paris because he studied medicine and pursued some original anatomical investigations on the human body while there. The focus will be on the latter.

Servetus was born of a noble and devout family at Tudela in Navarre, near Catalonia, Spain. He was educated at neighboring Huesca College and then attended the University of Saragossa, located in the province of the same name. He was then sent by his father to study law at the University of Toulouse, third oldest French university, founded in 1229 in southwestern France. At this institution, he became interested in religion and developed concepts contrary to the prevailing dogma. He believed that the idea of the union of the three divines of the Trinity was a mere phantasy. After publishing his views early in life, he was branded as a heretic and thereafter was in trouble with both the Spanish and French Inquisitors. Because of this, he lived in semihiding under the assumed name of Michael Villanovanus; it was under this appellation that he studied medicine in Paris, being supervised by the teachers, Sylvius and Guinterius. He was a fellow dissector with Andreas Vesalius, who was destined with him, to be subjected to the bigotry of the time, but in a different way.

Like his dissecting-mate, Vesalius, Servetus had to pursuc his anatomical studies in the absence of a plentiful supply of cadavers. He apparently did not deem it worth-while to go out and forage for himself and try to obtain subjects from available sources, such as executed criminals from the gallows or bodies resurrected from the grave, as did his partner. Perhaps, he grumbled about the shortage, as Vesalius did. While studying, he supported himself by writing and lecturing, his first book being, Apology to Astrology, indicating an interest in the influence of the stars upon human affairs (Bainton, '53).

In respect to his anatomical contributions, Servetus stands out for his observations on the respiratory system. He was probably attracted to this part of the body because he was searching for the location of the soul. Here he made three important 
observations: that the septum of the heart is impermeable, no pores being present; that the pulmonary artery is too large to serve solely for the nutriment of the lung (a "Galenic" function); and that the blood is aerated in the lungs. He believed, however, as did Galen, that the blood originated from the liver. These interpretations were published in the fifth volume of his Christianismi Restitutio in 1553 and indicate that he had a grasp of the basic significance of the circulation of the blood. This book was suppressed by the Church. Realdus Columbus published essentially the same concept in his De Re Anatomica, in 1559.

In spite of his efforts to remain incognito, Servetus fell into the hands of John Calvin, the French theologian, in 1553; he was imprisoned, tried for heresy and burned at the stake on October 27, 1553, at Geneva, at the age of forty-four years, along with 1,000 copies of his condemned book. Only three originals survive. This terminal event in his life has been described as one of the most deplorable tragedies in human affairs (Fulton, '53; Hemmeter, '15; Osler, '10).

$e$. Other Universities of the Renaissance. Not much information is available about certain other universities which existed during the period of the Renaissance: Venice, Pisa, Vienna and Louvain.

At Venice, the Council passed a law permitting dissection of a human as early as 1368. In 1404, a public anatomy was conducted by Prof. Gallazzo di Santa Sofia, the sittings lasting for eight days. A collection was taken up from those attending and the proceeds turned over to the faculty. This is the only instance I have found of this monetary practice. No further anatomies were held for twelve years. Dissection was included as a definite part of the medical curriculum in 1433 . Statutes were made regulating anatomy in 1495 but it was not until 1658 that the university was able to acquire its first skeleton. Nicolai Massa, one of the best known syphilologists of his time, with patients coming from all over Europe to see him, is said to have performed nine demonstrations on human cadavers between 1524 and 1536. An anatomical theatre was built in 1552 .

Berengario da Carpi (1470-1550) cannot be placed in any one school, because he was a member of the faculties at both 
Pavia and Bologna (1502-1527), where he taught surgery and anatomy. Since he is classified as one of the restorers of anatomy, he should be given consideration. That he was a prolific dissector, is indicated by the statements that he anatomized more than 100 cadavers, possibly as many as 300 . As an investigator, of the Renaissance period, he refused to be a blind follower of Galen. In his book, Carpi Commentaria super Anatomia Mundini, he introduced, for the first time, a set of anatomical figures, twenty-one in number, drawn from human dissections. It was published in 1521. They surpassed in quality those of his predecessors. He also pioneered by writing a short introduction to his book.

The life of da Carpi was made miserable by the machinations of the agents of the Inquisitors, who objected to some of his opinions regarding the organs of generation. Because he advocated that surgeons study the living body through opportunities presented in wounded persons, he was unjustly accused of dissecting living men. He was the first anatomist to give a correct description of many structures of the human body (Buck, '17; Korns, '37; McMurrich, '30; Singer, '25).

\section{Anatomical Illustrations during the Renaissance.}

Not much was done in the way of anatomical illustrations before the Renaissance; it wasn't until the beginning of the 16th Century that this aspect came to the forefront and was integrated with textual material in books.

The dawn of medical literature in Europe began in A.D. 1070 with the introduction of Constantine's Pantegni, two books on anatomy, based on animal dissection. Following this, during the 12th Century, five books were written by authors of the medical department at the University of Salerno; all were based on the earlier work of Constantine's Pantegni.

Between 1491 and 1543, about 100 different anatomical woodcuts were published. The noteworthy ones were stylized drawings or "primitives" in John Peyligk's Philosophiae Naturalis (1499), Magnus Hundt's Antropologium (1501) and Laurentius Phryesen's Spiegel der Artzny (1518), whose illustrations were the best of the group. Characteristic of the times, was widespread plagi- 
arism and great dependence on authority; independent observations were rare. There was another type of picture which apparently had the widest circulation of all; in fact, they were found all over the world. They were designated as "five-figure series" and their origin is obscure. There is a tradition that they go back to Aristotle. They are all characteristically alike, being portrayed uniformly as five, crude, human figures in squatting positions showing bones, muscles, nerves, arteries and veins. Sometimes, a sixth figure represented a pregnant woman or the generative organs of both sexes.

Early in the 16th Century, one page illustrations, known as fugitive sheets, were popular among the general public and medical men. These were commonly printed on soft, thick paper about 30 by 40 centimeters. In these, the figure was ordinarily surrounded by the textual material with a decorative margin on the outside. They were usually printed in black and white but some were in color and in different languages, in Latin as well as the vernacular. Some were undoubtedly printed to satisfy the curiosity of the common people; the so-called Adam and Eve plates revealing the abdominal and sometimes thoracic viscera were especially popular (Crummer, '23). 


\section{[IX]}

\section{ANDREAS VESALIUS-A.D. 1514 to 1564}

\section{A. Introduction}

A

ndreas Vesalius stands out as one of the greatest medical men of all time. A single contribution of his is ranked as among the ten most significant and influential in the literature of the profession. His publication in 1543 marks a turning point, not only in anatomy, but in the entire field of medicine. Although many writers have been attracted to him in the past 400 years, the details of his life, the circumstances and extent of his labors and the impact of his work upon the progress of medicine are not generally well-known. Probably few men have seen or read his original works. Over four centuries have elapsed since his death; he wrote in Latin and his writings are now found only in the great medical libraries which may be some of the factors which account for this.

What no other man could do for 1400 years, Vesalius did. He neutralized completely, though not immediately, the authority of Galen; recast the instruction of human structure; started basic medical research in anatomy, physiology and surgery in a new direction; illustrated his dissections accurately; destroyed long standing tenets, superstitious and otherwise, and made many new discoveries. He ranks in the same class as Bacon, Galileo, Descartes, Newton, Lavoisier and Bichat in respect to his creative contributions to society.

It took a man with certain definite qualifications to make these accomplishments: youth, enthusiasm, power of observation, courage and diligence, and Vesalius had all these. His masterpiece, De Humani Corporis Fabrica, was before the public prior to his thirtieth year in the form of the most accurate, complete 
and best illustrated treatise on anatomy the world had seen. Probably no other piece of writing in the history of medicine precipitated such stirring, mental reactions, both positive and negative. A wide range of emotions were aroused and were slow in declining. It was with a scalpel, the hand of an artist and the above human traits that Vesalius created probably the greatest revolution in medicine. He has been called the "Luther of Anatomy."

\section{B. Early Life}

Andreas Vesalius was born in Brussels on the last day of the year in 1514 under astrological conditions which were judged to be favorable by one Jerome Cardan. The placenta and caul of his afterbirth were carefully preserved by his mother who, along with most others, ascribed remarkable, magical powers to them. Cardan, an Italian practitioner and mathematician; whose real name was Geronimo Cardano (1501-1576) evidently believed in astrology, as did many other doctors of his day.

For four generations, at least, the male forbears of Vesalius had been interested in medicine and had occupied high positions in the royal court of Belgium. Some were noted for their literary flare. Vesalius' father served as an apothecary to Charles V and Margaret of Austria; he accompanied the illustrious Emperor upon numerous journeys and military expeditions. His mother, whose maiden name was Isabella Crabbe, had unbounded faith in her son, believed he was destined to accomplish great things, and exerted considerable influence over him. It was she who preserved the manuscripts and books of her husband's ancestors and made them available to Vesalius. She undoubtedly instilled into him the traditions of the family, their accomplishments in the field of letters and medicine, as well as the importance of their service and loyalty to their sovereigns.

The early life of Vesalius is shadowed with some obscurity. It is on record that he attended the University of Louvain, located a few miles from his home, which in the number of its students, ranked second to the University of Paris; there, he studied the ancient languages (Greek, Latin, Hebrew, Arabic) with facility, and this background stood him in good stead in later literary controversies. 
The field of human structure appealed to Vesalius in his boyhood, and for this pursuit, his powers of observations were more than adequate. At first, he tried to learn anatomy by reading several texts (Albertus Magnus and Michael Scatus) but decided this was a poor way to absorb and understand the factual knowledge pertaining to the subject. He ventured on a practical program of dissection, obtaining animals which were easy to catch: mice, moles, rats, dogs and cats.

\section{Vesalius in Paris}

Vesalius, desiring to follow the profession of his ancestors, selected the University of Paris for his medical education. He reached there in the year of 1533 at the time when the French capital was the acknowledged Mecca of the medical world. The reputation of the institution had attracted a great many young men, some from the most remote parts of Europe. Medicine was being taught there by such eminent professors as Jacobus Sylvius, Jean Fernel and Joannes Guinterius. Of the trio, it was the first who had the best reputation; he had studied under Jean Fagault, a famous Parisian practitioner and surgical author. A résumé of his unusual life has already been given.

Guinterius (1478-1574) was a colorful figure in his own right. Born of very humble parents, in Andernach, Germany, near Coblenz, he was sent to the University of Utrecht, at an early age. Because of his poverty-stricken condition, he was forced to leave that educational institution. He migrated to Deventer, Holland where he found it necessary to beg in the streets in order to survive. Apparently, he was able to accumulate enough funds to matriculate at the University of Marburg where his brilliance and talents were recognized and where he was treated with respect. After teaching in the small town of Gosler, he made a big academic jump to the chair of Greek in the famous University of Louvain.

Guinterius went to Paris to study medicine in 1525, eight years prior to the arrival of Vesalius; he received his Bachelor's degree in 1528 and his full medical title two years later. He was brillant in his final examinations and received the accolades of 
his professors. Electing to remain in Paris, he taught anatomy and practiced medicine, both with considerable success and renown. Adept in Latin, he translated the writings of numerous Greek medical authors of antiquity. So well did he project himself by both the written and spoken word, that his fame spread beyond the boundaries of France. The enlightened King Christian III, of Denmark, tried to entice him into his court, without success. Because of his religious views, having been converted to Lutheranism, his life was threatened, so he departed from Paris enroute to Germany. Residing a short time in Metz, he moved to Strassburg, on being appointed professor at the university; there he was received with honors and ceremony. His tenure at Strassburg was temporary due to the insecurity of his position, engendered by some of his enemies; this caused him to resign his chair. Following this, he spent considerable time traveling throughout Germany and Italy. In 1562, at the age of seventy-five, he was made a nobleman by Ferdinand $I$ in appreciation of his merits and contributions.

While teaching anatomy in Paris, it was the fate of Guinterius that some of the enrolled students who sat upon the benches in his department, eventually outshone him: these were particularly Vesalius, Servetus and Rondelet. Like his predecessors and all of his contemporaries, with the exception of Vesalius, he was a disciple of Galen. His lack of long-lasting medical stature is due to the fact that he failed to grasp the truth that anatomical science is based on the results obtained from studies of human dissection.

The other luminary at the University of Paris was Jean Fernel (1485-1558). Although he was regarded as the ablest physiologist of his time, he was also a skilled anatomist and surgeon. He sought the best from the various medical systems then extant and had a greater breadth of view than either Sylvius or Guinterius. A reformer at heart, he stood for freedom of thought and was in opposition to ancient dogmas. By means of his daring, he helped to point out the road to progress in anatomy.

How did Vesalius react to his environment at the University of Paris? Apparently, he did not like what he saw and later was not backward in his criticisms. He resented the lecturing and theorizing from Galen's texts and thought there was far too little 
dissection. Anatomizing was performed in traditional style by ignorant and uncouth barbers; not once was Guinterius seen to use a knife upon a cadaver. Few human bodies reached the amphitheatre and those which did, lasted less than three days. The studies made were superficial, at most; they included only the intestines and abdominal muscles. Vesalius felt that the teachers were ignorant but unaware of it. He took matters into his own hand, grabbed a scalpel, pushed the prosectors aside, and systematically proceeded on his own. Dissecting down to the bones, with Servetus, he won the admiration of Guinterius, who now was able to demonstrate to the class, for the first time, the muscles, arteries, veins and nerves of the whole body.

It was at Paris that Vesalius made a resolution: that he would henceforth devote his energy, talents and his life to anatomical study and teaching. One facet of his character now stood him in good stead; namely, his strength of purpose. His goal became the standards which were used at the famous Alexandrian School under the Greeks, Herophilus and Erasistratus, who represented his ideal. He decided to take advantage of every opportunity, and even to look for them, to dissect both animal and man. He anatomized numerous dogs and haunted the cemetery (Of the Innocents) and the place where the bodies of executed criminals were deposited, looking for a suitable skeleton, sometimes at his own peril. Collecting bones, in such fashion, he was able to become a master of the osseous system, even to the extent of identifying the finer parts blindfolded. At least one time, he was questioned for having possession of them in his home, by the police. Since his anatomical gifts were recognized by faculty and students, it was not long before he was put in charge of dissections; these were conducted to the satisfaction and astonishment of all, particularly the barbers. There is a legend that Vesalius never dissected a cadaver without first asking God's pardon.

Vesalius studied three years under Sylvius at Paris. Although not happy there, he undoubtedly laid the foundation for his monumental work on the Fabrica. 


\section{Professor of Anatomy at the University of Padua}

After his studies at the University of Paris were completed (1536), Vesalius returned to Louvain, Belgium where he became affiliated with the University. Apparently, one of the biggest events of the year was an expedition made to a gallows outside of the walls of Louvain in search of bones; accompanying him

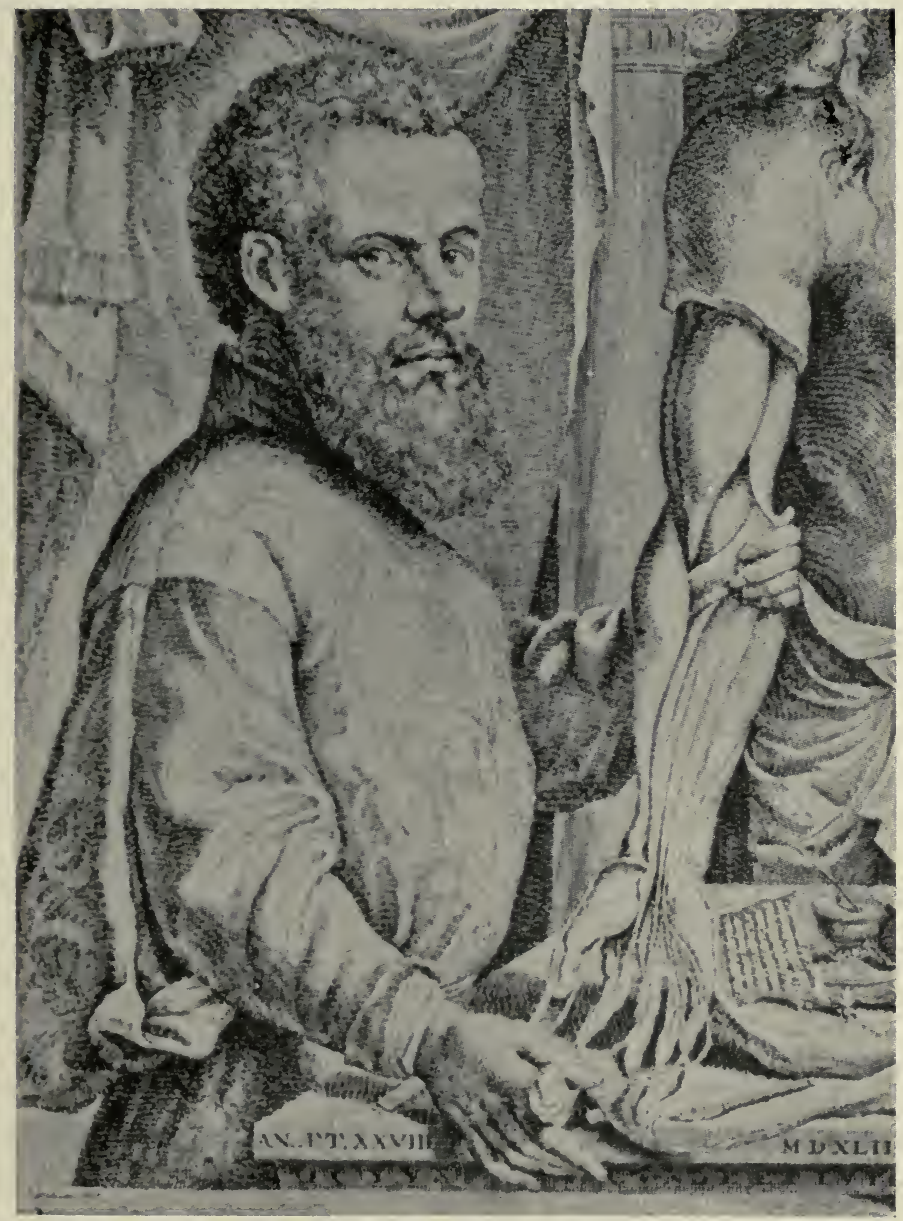

Figure 8. Andreas Vesalius (1514-1564). From Garrison, F. H.: An Introduction to the History of Medicine, Fourth edition. Philadelphia, W. B.

Saunders Company, 1929. By permission of W. B. Saunders Company. 
was a faithful friend, a mathematician by name of Regnier Gemma. There, he found, what he had been searching for: a skeleton which from his view from the ground, looked complete with the bones held together by the ligaments of the joints. It was the remains of a noted robber, who had been treated according to his deeds; he had been chained high up on the gallows, and then slowly roasted alive. The flesh had been picked clean by birds, which had probably found it a rare delicacy. Vesalius climbed up and secured the skeleton from its lofty perch and conveyed it to his home. On examination, he found several parts missing: one finger, a patella and a foot. He was able to supply the missing parts on a second expedition to the same spot.

During his stay at Louvain, Vesalius conducted the first public anatomy that had been held in that city for eighteen years. He also issued a free translation of one of the Almanser books written by the celebrated Rhazes, an Arabian physician (A.D. 850-923); this particular volume was not anatomical but rather was concerned with the therapeutics of all parts of the body. It was judged to be a valuable addition to the literature of the time.

The next highlight in the life of Vesalius took place in Padua, Italy. He migrated to that country in 1537, his first stop being the enlightened and prosperous city of Venice. There probably was not another site, in the then existing world, where the academic climate was more favorable for the pursuit of anatomical studies. Here, there were no taboos working against the study of anatomy: rather, it was actually encouraged, particularly by a group of Theatin monks, established in Italy in 1524. Their aims were to preach the gospel, combat Lutheranism and elevate clerical and lay morality. They were forbidden both to beg and hold property. The group trusted solely to the unsolicited contributions of the faithful. In Venice, they devoted themselves to the care of the sick which accounts for their interest in anatomy. One of the co-leaders of the organization was the famous Ignatius Loyola, founder of the Jesuits, whose chief purpose in life was to work toward a world-wide acceptance of the doctrines of Catholicism.

In Venice, Vesalius searched for suitable anatomical material. It is not certain whether he was successful, but he may have 
conducted a public demonstration in anatomy while in residence there. By a happy circumstance, he was introduced to a man important to his future, namely, his countryman, Jan Stephan van Calcar, artist extraordinary, an anatomical dissector in his own right and according to Vesalius' own words, he ranked "with the divine and happy wits of Italy" (Ball, '10).

During the last month of the year, 1537, Vesalius moved to Padua in order to gain all the rights and privileges of a fullfledged physician. Shortly after receiving his doctorate there, he was appointed Professor of Surgery at the renowned University of Padua, with the understanding that he would teach anatomy separately. This may have been the first appointment ever made to a purely anatomical chair. At this time, he was only twentythree years of age.

Imbued with zeal and enthusiasm, his first act was to improve the course of instruction in anatomy. Contrary to precedent, he took over all the duties revolving around teaching: lecturing, demonstrating and dissecting. The ignorant barbers, universally employed as dissectors, were avoided and substituted with students. Every means was taken to have an adequate supply of human anatomical material even if it had to be secured by stealth, but lower animals were also included in his program. It was they which were vivisected: dogs, pigs and rarely cats.

The center of attraction in the anatomical curriculum was the elegant aula where Vesalius conducted his course; it was built of wood and could seat 500 persons. In its middle, was placed a table, under which was a box containing bones and joints. An assembled skeleton was conspicuous at one end of the room. Those taking the complete course were subjected to a strenuous session: the entire day for a period of three weeks. As visual aids, he used drawings and charts made with his own hand, sometimes in the presence of an assembly. The dissecting instruments he used were crude by comparison with modern standards. He showed the ones utilized in one of the illustrations in the Fabrica: knives, hooks, sounds, bristles, cannula, catheter, hammer, saw, thread and a sponge.

Vesalius made an auspicious start at Padua. It became known throughout the entire community, probably by word of mouth, 
that the young Belgian professor was to give a course of instruction in anatomy. Long before the hour set, for a demonstration, all seats, even standing room were taken, which meant that well over 500 persons were interested enough to attend. The audience was comprised of professors, students of medicine, city officers and members of the clergy.

The style of his anatomical presentation, which was an innovation, was made evident on this historical occasion by Vesalius. He walked into the chamber, and without wasting a moment, launched into preliminary remarks about the significance of anatomy and the methods which had been used previously in acquiring knowledge. Then, the structural divisions were rapidly pointed out on the flayed body of a dog; this was done to conserve human material. When the cadaver was placed upon the table, all eyes were focused upon it with possibly the realization that this was a rare event and that they were privileged persons.

The dissection, made by Vesalius, was performed and in regular sequence: abdomen, pelvis, thorax, face and neck muscles, the remainder of the head and finally the upper and lower extremities. Physiological deductions, based on the anatomy of the parts, were made throughout; pathological conditions were considered as briefly as possible. Structure was particularly highlighted because he feared fatiguing his audience with too much variety. Numerous nonhuman vivisections ended the anatomy lessons. His large and elite audience remained with him to the end. Although, it must have been both a physical and mental strain for Vesalius, as he did most of the work, both preparatory and actual, he never mentioned it and gave no signs of it. This and the others which he subsequently presented, were profitable from the standpoint of financial remuneration.

Vesalius was given the honor of conducting two public dissections at the University of Bologna located not too far away, probably in the years of 1539 and 1540 . This was the institution where Mondino had revived the practical teaching of anatomy about 200 years previously. A special, wooden building was erected for this event; three bodies were turned over to him for the first class. Using the same standards as at Padua, he handled the situation in grandiose fashion. A large and select gathering 
was present to witness a demonstration proving that Galen's description of the vena azygos was incorrect. Apparently, more cadavers and an ape were disposed of during the second meeting. On this occasion, he presented skeletons of man and ape, to the Professor of Medicine at Bologna, Andreas Albius.

The first anatomical contributions which Vesalius made at Padua were done in the interests of his pupils. First, he articulated a human skeleton for use in the classroom. In addition, he prepared a set of six loose-leaf anatomical plates, the Tabulae Anatomicae, intended to assist beginners in anatomy. Finally, he edited Guinterius' Institutionum Anatomicarum, which was issued in April, 1538.

\section{E. The Fabrica}

Probably every word of approbation found in the dictionary has been used at one time or another by various historians in describing Vesalius' publication, the Fabrica. The following is a quote from Fisher (from Ball, '10): "it was and is a glorious book, a rare and precious monument of genius, industry and liberality." All concur that it ranks as one of the greatest achievements in medicine. In modern times, no one speaks derogatorily about it. Three years of arduous labor were spent in completing it according to the standards of three individuals: Andreas Vesalius (anatomist), Jan Stephan van Calcar (artist), and Johannes Oporinus (printer). A fortune was expended upon the illustrations and publication and there is little doubt that it was largely a labor of love. One can easily imagine the amount of time and effort which was put into the quaint initial letters and the figures which embellish them. The engraving on the title page is considered to be one of the most spirited and elaborate to be found in medical literature.

All of the pictorial representations were made on wood blocks which were printed in Basel, Switzerland, conveyed there safely from Padua, in the summer of 1542 , by a merchant friend named Danoni. Early in the following year, Vesalius went to Basel to supervise his precious work. While there, he conducted another public anatomy, the first held in the city in eleven years. The skeleton of the subject used, which he articulated, was pre- 
sented to the University of Basel, with his compliments. Parts of this exist today and it is thought to be the oldest anatomical preparation extant.

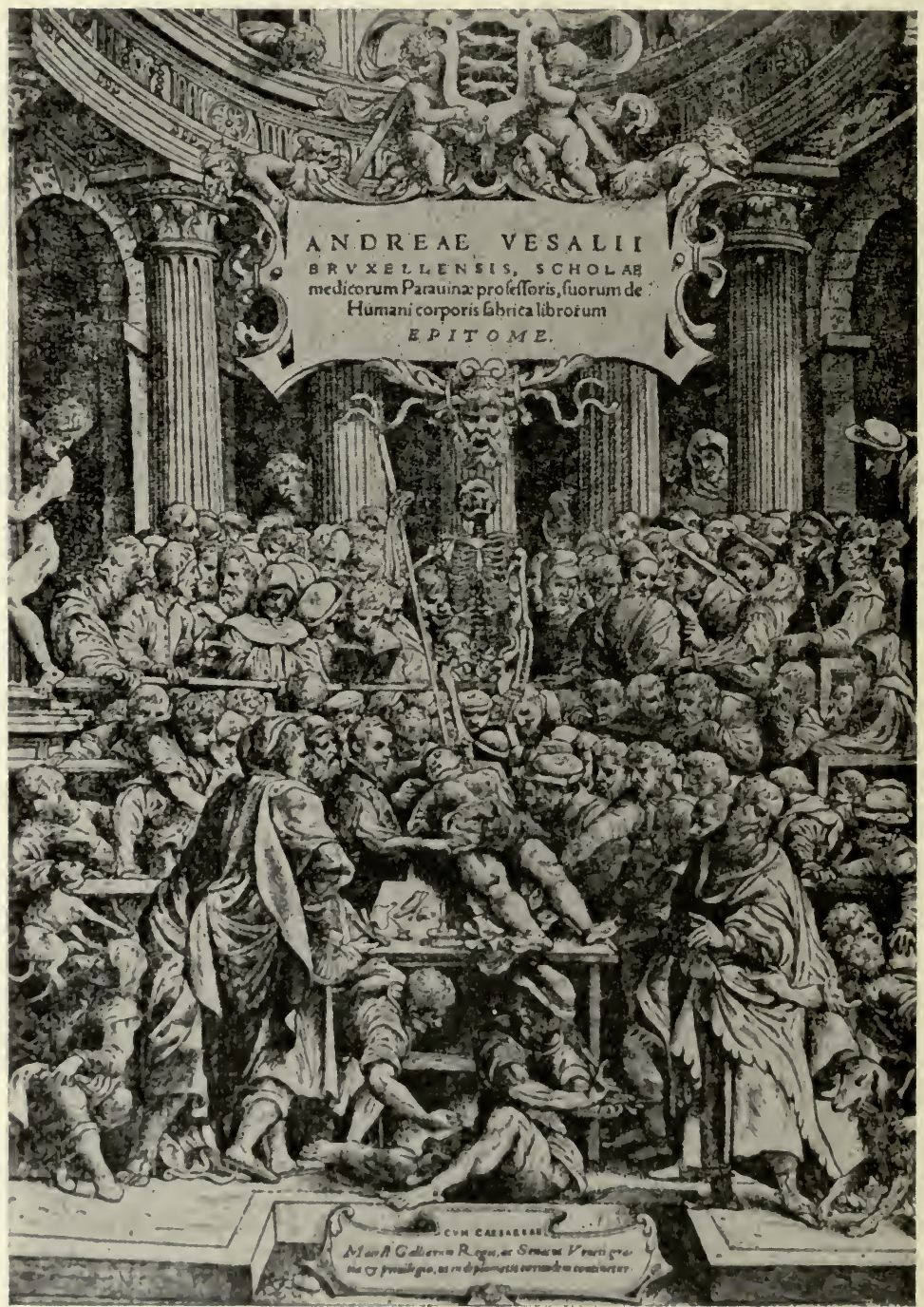

Figure 9. Title Page of Vesalius' Epitome, 1543. From Ball, J. M.: Andreas Vesalius the Reformer of Anatomy. St. Louis, Medical Science Press, 1910. 
Although the illustrations in the Fabrica are of surpassing quality and ingenuity, the road to their completion was confronted with many an obstacle. His artist, according to Vesalius' own words was so obstinate at times that he felt exasperated and tormented. Calcar may have complained about having to draw from skinned and foul smelling bodies; it was impossible to keep them for any length of time, because antiseptic injections and preserving fluids were unknown. Vesalius certainly complained of the huge sums it was necessary to pay to keep his artistic project alive. For many years, it was assumed that Titian was the artist in question rather than Calcar, his favorite pupil, but this has been settled in favor of the latter. The most satisfactory plates in the book are those which portray the undissected body, the deeper bones and muscles.

It was the Fabrica, with its dissections and plates, which made the reputation of Vesalius. Six hundred fifty-nine folio pages long, in the form of seven books, it was dedicated to Charles V. The text is lucid and yet succinct and it rectified many anatomical errors made by Galen and others. It touches very slightly on anthropology, more so on physiology which is correlated with anatomical description. The osseous system, as a whole, is described correctly for the first time. That part on muscles and ligaments is superior to anything previously done, but does not match the standards of the book on bones. The superficial muscles are beautifully illustrated and those in the deep group show anatomical accuracy. He described the arteries and veins adequately but interpreted their physiology in terms of ancient theory; the arteries were the carriers of vital spirits, whereas the veins were the true blood vessels; he also stated that the heart was filled with numerous foramina.

Considering the period, Vesalius' work on the nervous system was surpassing and elaborately minute. In his other books, admirable accounts are given of the organs of nutrition and the respiratory system.

In general, the Fabrica, was remarkably free from errors which, though present, were completely overshadowed by its brilliance. Vesalius was successful in laying the foundations of our current knowledge and in overthrowing the idol of authority, 
Galen, whom he called the Prince of Physicians. In respect, to the latter, he apparently had many anxious moments in challenging some of his concepts. Some historians have evaluated Vesalius as outranking men in other fields: Copernicus, Galileo, Torricelli, Pascal and Christopher Columbus. The reasoning behind this judgment was that the first study of man is man and that Vesalius had this object in view and admirably attained it; by acquiring fresh knowledge of his own structure, man has been able to expand his existence (Portal, 1770, quoted from Ball, '10). There is little doubt that modern medicine begins with the publication of the Fabrica.

Vesalius was violently criticized by the numerous Galenists of the era. Leading the attack, was his former teacher, Sylvius. He spoke of Vesalius as a madman, as a Vesanus, whose pestilential breath poisoned Europe. Others included Realdus Columbus, Dryander, Eustachius and Fallopius. Even his friends were dubious about his results and serious discussions were held on both sides. In the end, the Galenists were completely overthrown.

\section{F. Vesalius (1543-1564)}

Vesalius had felt it necessary to take a years leave of absence from Padua, in order to assist Oporinus, the printer, in Basel, with the publication of the Fabrica. When he returned to the University in late 1543, he found that his book had fermented extreme opposition, particularly in his former pupil and friend, Realdus Columbus, who was then lecturing in anatomy. This developed into a personal and bitter controversy between the two, creating wounds which were never healed. Other Galenists joined Columbus in violently attacking Vesalius in an effort to sully his reputation.

Apparently, the atmosphere at Padua was so uncongenial and hostile that Vesalius went to Pisa early in 1544, where he is known to have conducted an anatomy. From there, he moved to Bologna and made some special dissections upon two human subjects. The University of Pisa offered him a chair which he refused. It was at this moment that Vesalius, apparently at low ebb, suddenly and perhaps impulsively decided to end his scien- 
tific career. In a fit of passion, he threw into the fire a manuscript he had written on the practice of medicine, based on pathological considerations. He had tired of the useless efforts necessary to convince men of the truth, of the disputes, arguments and persecutions. In this frame of mind, he accepted the appointment of military surgeon to Charles V of Spain which necessitated a shift in residence to Madrid; he was now only thirty years of age. After serving with the Emperor in the fourth French War, he returned to his native country, January 1545 . He continued to serve in the employ of Philip, who succeeded his father. The latter had surrendered his territories to his son so that he could enter a cloister. From both royalists, Vesalius received many honors over a period of two decades, although he found Philip narrow and bigoted.

In 1564, for no understandable reason, at the height of success, Vesalius left Madrid. At that time, he was a favorite in the Spanish Court and had amassed a good sized fortune. Jealousies, no doubt, existed between him and members of the Spanish profession, who regarded him as a foreigner. The controversy concerning the fallibility or infallibility of Galen had continued unabated; although Sylvius, the most outspoken had passed away, others continued to oppose him. There were those, however, who had chosen Vesalius' way of teaching anatomy: Fallopius at Padua, Rondelet at Montpellier, Massa at Venice, and Fuchs at Tübingen; all were challenging Galen at every opportunity.

The atmosphere at the Spanish court was not conducive to any sort of scientific study. The Church had remained powerful and the Inquisition succeeded in neutralizing all intellectual life; the city of Madrid was priest-ridden and the populace was ignorant and superstitious. Anyone who pursued the study of natural knowledge, was frowned upon.

After reading a copy of Observationes Anatomicae, written by his former pupil Fallopius, who had died in 1562, Vesalius decided to make a reply in the form of a book. He returned to Italy, conversed with a printer in Venice, about the possibility of publishing it. Then, he disappeared from Italy, shipping out for Cyprus, in company with Jacob Malatesta, the commander of the Venetian forces in that island. From here, he continued on to 
Jerusalem intent on a pilgrimage to the Holy Land, for what reason, is not definitely known. The one often quoted is based on a letter written by Herbert Languer to Dr. Casper Peucer on January 1, 1563. It is as follows: believing a young Spanish nobleman had succumbed while he was in attendance, Vesalius obtained permission to perform a post-mortem examination. When so doing, he observed the heart beating. This came to the attention of the youth's parents, and not satisfied with prosecuting him for murder, they presented his case to the Inquisition; this was done in hopes it would mete out greater punishment than would likely occur through the channels of common law. The story goes that the King of Spain interceded in his behalf on the condition that he make penance by a pilgrimage to the Holy Land (Ball, '10).

One thing is really known for certain and that is that the voyage was made, the Holy Sepulchre visited, both against the wishes of Vesalius. He was returning to Italy with the understanding that he would take the chair of anatomy at Padua, vacated by the death of Fallopius. His ship was wrecked upon the island of Zakynthos in attempting to ride through a violent storm in the Ionian Sea. He died there of exhaustion at the age of fifty years, on October 15, 1564.

\section{G. Vesalius and his Personality}

Vesalius was of short and stocky stature; he is described as being burly in appearance, having shaggy hair and beard and a tip-tilted nose. Although he might not have been very tall, he looked every inch a man.

In many ways, Vesalius was a gifted though possibly not a clever individual. He was unquestionably devoted to intellectual pursuits. Living in a period when medical thought was slowly changing from mediaeval mysticism to the rational study of man, he was a person who devoted himself largely to a single purpose, that of studying the architecture, geography and structure of man. Against great odds, nothing deterred him in this goal. Tradition, bigotry, prejudice and professional pressure were all against him. In the face of this, it was necessary for him to 
have courage and pluck; these he possessed, in addition to youth, energy, zeal and a great capacity for work.

Along with these, he was proud, sensitive, impatient of opposition, stormy in temperament, indignant to abuse and at times ungracious with his opponents. He was not averse to making derogatory remarks about his former teacher at Paris, Sylvius. Like all good anatomists he reacted to the beauty, design and morphology of the human body and he had enough of the artist in him to be able to set high standards for the superb illustrations which were incorporated into the Fabrica. He had to be a genius in assembling and coordinating the structures which he saw. This had to be done in order for him to become a pathmaker and a proclaimer of truth. He was a pioneer in daring to observe.

Due to a combination of events, Vesalius completed one of the great masterpieces of medicine before he reached the age of thirty years. This was it, his creative contribution to society; nothing more came from his pen. Yet, the Fabrica shattered tradition and eventually the centuries of long idol worship of Galen, and brought science back again to rational observation (Doolin. '33; Garrison, '15; O'Malley and Saunders, '53; Welch, '15). 


\section{[X] \\ DISSECTION ON THE EUROPEAN CON- TINENT AND IN ASIATIC COUNTRIES DURING THE MODERN PERIOD-A.D. 1650 to 1958}

$\mathrm{H}$ ing the modern period, has been characterized by stability and lack of drama and struggle. This probably accounts for the fact that relatively little has been written on the subject during this interval. Anatomizing began there six centuries ago; laws were enacted early which were soon modified and liberalized. The use of executed criminals as the sole source was uniformly eliminated. This removed the infamy which has had such a neutralizing effect in respect to obtaining an adequate supply of subjects. The problem on the Continent, in late years, has been related principally to the interest and actions of burial, insurance and church societies which provide funds for interment.

Outside of Japan, human anatomizing is almost nonexistent in the Asiatic countries about which reports have been made. The following is a review of the main events which have occurred in some of the countries of Europe and Asia.

\section{A. France}

It appears that dissection has had a rather successful history in France. There, the National Faculty of Medicine was authorized to accept all those bodies, which remained unclaimed for twenty-four hours after death, from civil hospitals, prisons and almshouses. As early as 1790 , France repealed the law permitting dissection of murderers, which removed one of the main stigmas attached to the practice. Approximately 16 sous were paid to attendants in the hospitals for each body. This policy was backed 
by the schools of health. To violate a sepulchre, meant three to twelve months imprisonment and a 60 to 200 franc fine (Bailey, 1896; Guttmacher, '35; Harrington, '05; Mackenzie, 1824).

It was the chief of the anatomy department at the Faculty of Paris who was required to send carriages to pick up and transport the unclaimed bodies; they were sewed up in mats and no public excitement existed over this arrangement. Before pathology began to claim a share of subjects for autopsy purposes, the medical school received as many as 2,000 per year, afterwards 1,000 to 1,200 . Theatres of anatomy existed in all the great hospitals and a license was needed to conduct classes. The policy of permitting students to dissect started early in France; each student was charged 5 to 10 francs per cadaver. After anatomizing, the bodies were again wrapped in mats or cloths, carried to the local cemetery where they were buried; the cost for this was about 12 sous. With this system, exhumation was not a problem; it was learned that the French people did not oppose dissection although some may have had an aversion to it. On the whole, there was a deep conviction of its utility (Abernethy, 1825; Harrington, '05).

The French, through Petit, Lieutard and Desault in the 1750 's, gave a new orientation to anatomy by advocating the practice of dissecting from the surface of the cadaver to the depths beneath, until bone was reached. Eventually many English students were attracted to Paris where they found that every aid was given to promote anatomical science (Doolin, '51).

In 1834, Astley Cooper made a tour of France and described visiting anatomical departments. He attended one having four large rooms, two of which had numerous bodies in them. Three and one-half to eight francs were charged the students who dissected, depending upon whether the subject had been opened or not. A large garden was accessible where they could either sit and relax or stroll about for a change. The pupils worked in groups of three on a cadaver: one reading, one dissecting and one drawing (Cooper, 1843).

Oliver Wendell Holmes went to Paris to study medicine about the same time and found that the students were free to doubt and dispute what they were taught. He personally paid 50 sous, about one-third the price of a chicken dinner for a cadaver; 
there was no evidence of any shortage; he and some of his classmates sometimes received a specimen at noon and had made considerable progress in dissecting it by nightfall (Fraser, '50).

John Y. Bassett, of Huntsville, Alabama, found the same favorable conditions prevailing in Paris, in 1836. Subjects were cheap; he paid 40 sous for the body of a child and 6 francs for that of an adult. He anatomized from eleven to two daily. Opportunities for summer work, were excellent. According to him there was an anatomical school located at Clamart, which had room for 200 cadavers; these also could be purchased for a mere trifle. Imposing, residential places were available for the students. No prejudice existed against the practice and even hospital subjects who were aware of their fate, made no objections (Osler, 1896).

No further data on subsequent events in the history of dissection in France are readily available. The scarcity of information, over a period of the last 130 years, may indicate that no serious problems have existed in that country, at least not enough so that they have been publicly expressed.

\section{B. Germany}

Near the termination of the 1600's, human dissections were a big event in Germany; they were not so frequently performed as in France, Italy or Holland. Characteristically, they were held at long intervals and each one became a civic event attended by gay festivities. The Professor of Anatomy at Heidelberg, in 1685, John C. Brunner, pioneered in providing anatomical material for human dissection. He was able to obtain the bodies of all soldiers dying at the Heidelberg Garrison. These, he dissected in the presence of his students. In general, such an event was attended by professors, doctors, students, noblemen, civic administrators and anyone who might be interested. At most, one or two anatomies were performed publicly each year. As soon as a cadaver was made available by the magistrate, notice of the coming ceremony was published. The essence of such an ad is the following: the human body compares to a machine; a knowledge of anatomy is important in medicine; dissection is not against the laws of 
nature or reason; every person would profit in the end by attending (De Lint, '34; Garrison, '29; Major, '41).

In the development of anatomical laws, those individuals dying in prisons, penitentiaries and by suicidal action were automatically given up for dissection unless a certain sum was paid to the school prior to death. Also, accessible were the bodies of paupers, executed criminals, those supported publicly and prostitutes. From these sources, an ample supply was available and resurrection men were unknown (Bailey, 1896).

According to Walton (1882), these standards prevailed in 1882. While he was at Leipzig University, much time was spent dissecting, the material was abundant, the main source being executed criminals and suicides. At this institution, there were six, well-lighted, dissecting rooms: one for 150 students; two for 50 and three were smaller. Anatomical study extended over a twoyear period after which each student had to pass a rigorous state examination.

During the next half-century, the situation changed in Germany. About 1930, there were twenty-three university medical schools in the country and all instruction was standardized. During the 1928-1929 academic season, there were 2,277 medical students in Berlin alone. Gross anatomy was taught three semesters a year and dissection was required during two. The practice of anatomizing was substandard because of the shortage of cadavers; often sixteen or seventeen students studied on one specimen, or six were assigned to one-quarter of a subject. Sometimes, the class was divided in half, each taking turns examining the same subject. One brain had to suffice for twenty-five to thirty students in neuroanatomy. The scarcity of bodies was due to several factors: relatives claiming them, the activity of burial societies and the zeal exhibited by priests, embalmers and gravediggers in collecting fees for interment. The last three named were interested in seeing subjects inhumed for monetary reasons and they were especially active in small communities and rural areas. Teachers were overloaded with work because they were too few in number; laboratory exercises were frequently taught in shifts and the quizzes were inadequate and varied according to the school (Conel, '31). 


\section{Italy}

There is nothing much to mention about the status of anatomy during the modern period in Italy. If any serious difficulty was encountered, little publicity has been given to it. The source of anatomical material was the hospitals. All unclaimed persons who succumbed there, were released for dissection, but friends could claim them provided they defrayed the costs of the funeral. This arrangement took care of the dissecting needs, in general; if a shortage developed, anatomists could resort to the poor people who died and had to be buried at public cost. These were deposited in the parish churches of Italy in special chambers, after religious ceremonies were performed. At night, the bodies were removed either to a dissecting-room or to cemeteries outside the town. Under these standards, body snatching did not exist (Bailey, 1896).

\section{Holland}

The early history in Holland, in respect to human dissection, indicates that the times were prosperous. Particularly, interest was shown in anatomy by the citizenry. The possession of an anatomical theatre was regarded as being as much of an asset as an art museum is today. Anatomizing seems to have gotten its start at the University of Leyden during the 17th Century (Singer, '25). They were frequently held in public and were popular. Dutch artists of the period attended and some of their paintings vividly portray such scenes. At Leyden, the medical school obtained its cadaver supply from the civil hospitals located at Amsterdam. Exhumation was unnecessary and unknown (Bailey, 1896; Castiglioni, '41; Viets, '30).

A peculiarity in that country, was that the public anatomies were presented on Sundays, provided there was a hanging scheduled for that day. These were boldly advertised in the newspapers which stated that seats would be available at 50 cents per person. The choice ones were reserved for physicians and surgeons. At the completion of the dissections, parts of the body could be purchased for a special fee (Meyer, '30).

The anatomical schools of Holland became well-known during the last part of the 17 th and the first of the 18th Centuries. 
Because of this, many students from Scotland, where they were experiencing anatomical difficulties, migrated there to complete their medical education. There is evidence that initial efforts at embalming were made in Holland. Frederick Ruysch (1683-1731) was considered to be a master at making injections and corrosion specimens (Blaine, '51; Cunningham, '03; Kerr, '01).

That the same fate befell Holland as did Germany is indicated by a statement of Sigerist ('34). He stated that many universities in Europe were having great difficulty in obtaining a sufficient number of cadavers and that, in Holland, they had to be imported from the colonies.

\section{E. Austria}

The first anatomical theatre was opened in Austria (Vienna) in the year of 1718 and a chair of anatomy established in 1739 . The government of that country lent every aid to promote anatomical science and the law was relatively liberal. Only unclaimed bodies were used for dissection and these were released to the teachers forty-eight hours after death. In Vienna, the supply came from the general hospital and this was sufficient for ordinary purposes. It was not necessary to resort to illegal means (Guttmacher, '35; Korns, '37; Lonsdale, 1870).

Because of this situation, the early Vienna schools also attracted students from the United Kingdom, who were handicapped by lack of cadavers. But again, the brakes were applied to the flow of subjects to the medical institutions, due in part to private, charitable and religious societies, which claimed nearly every body. In 1921, the students in anatomy had little opportunity to dissect and had to be satisfied with skeletons and museum specimens. Now and then, one group watched another anatomize. Some efforts were made to rectify this situation and further legislation was suggested (Correspondence, '21; Lonsdale, 1870).

The situation became acute apparently as early as 1912 . The number of students applying to the University of Vienna was increasing to such an extent that accommodations became inadequate. Repeated applications to the government to consider improvements were unsuccessful. In 1911, 1,500 students were put in 
four dissecting-rooms. To partially neutralize the crowding, the medical school administration decided to limit the number of entering pupils to 1,000 . Preference was given to local applicants but a few were selected from the Austrian dominions (Correspondence, '12).

Later, in the same year, the government relented and granted enough money to build two anatomical laboratories, large enough to permit 250 additional students to dissect. When completed, it was found that twice as many pupils applied as could be accepted. The number of bodies were reported as diminishing between 1900 and 1910 whereas the students more than doubled.

By 1930, the problem apparently, had not improved. Enough cadavers were on hand to keep the institute running for two years provided the number of freshmen was restricted to 250 native Austrians. At that time, the law provided that unclaimed bodies dying in state hospitals could be utilized for dissection. Suicides, which were partially anatomized at the Forensic Institute, were turned over to the anatomical departments. Sale of a body during life or the willing of one was allowed but rarely done.

Very little factual data exist on other countries in Europe, such as Switzerland and Portugal. Spain does not have a spectacular record in human dissection because the Spanish government was reluctant to authorize the practice. It actually didn't get under way until the beginning of the 19th Century (Harris, '19; Hume, '34).

\section{F. China}

In China, the medical profession was long looked upon as a fourth-or fifth-rate occupation. The populace regarded sickness as a visitation of god and tended to be passive about it. Human dissection was contrary to their ideas of future life and was generally considered with horror. Of all the branches of western culture, anatomy and pathology may be the last to enter China enough to establish a strong foothold. In 1913, dissection of a Chinaman, especially by a foreigner, was sufficient ground for a first-class riot (Clark, '13; Cowdry, '20a). 
In recent years, medical education in China has been tolerated rather than encouraged. Professional students, in this field, were of low caste and physicians were not in good standing. In Hong Kong, the British succeeded in making human dissection a part of the medical curriculum. The teachers there found that the Chinese made good students up to a point; they were good dissectors, made neat drawings but were apt to memorize (Clark, '13).

In 1920, there were twenty-six medical schools in China, most of them being regulated by foreign missions or agencies; only twenty-four teachers devoted full time to the teaching of anatomy. It was natural that they were very much overworked. To get enough funds to pay the staff, was a considerable problem. Only twelve of the twenty-six institutions had any sort of course in human dissection; there was no regular and sufficient source of bodies. Some were obtained after executions; these had to be sewed up and buried afterwards. Willed bodies had to be returned to the family and it was difficult to obtain the permission of the nearest of kin. In the large city of Peking, four bodies were obtained over an interval of one and one-half years. One school devoted 1,178 hours to the subject of gross anatomy. It was natural that the majority of instructors eventually came to rely upon the use of models. Skeletons, by contrast, were easy to obtain (Cowdry, '20a).

\section{G. Japan}

Comparatively, Japan has been better off than China. In 1920, there were twenty-five medical schools of various types: Imperial, War, Municipal and Private. Large, airy, and spotless wooden buildings were used. Anatomical material was plentiful. Kyota Imperial University used 433 bodies in 1913. The supply was controlled by the government and they were obtained from prisons, workhouses, university hospitals and old people's homes. Equipment was up-to-date. Most of the teachers were trained in foreign countries, and, in general, western standards were accepted although prejudices existed as to the free use of human subjects (Clark, '13; Cowdry, '20b). 


\section{H. Other Asiatic Countries}

\section{The Philippine Islands}

One medical school exists in the Philippines which provides instruction over a six-year interval. Modern anatomy is taught there as in the United States. The Filipinos make good students, especially when under the direction of foreign instructors (Clark, '13).

\section{Indochina}

One French medical school held classes in Indochina, in 1913, and served of little practical value. The courses were abbreviated and were given as a means to an end; little effort was made toward an evolution to higher education. The institution served more as a training ground for minor technicians than for medical students (Clark, '13).

\section{Iran}

According to Garrison ('33), who visited that country, only one medical school existed, which was located at Teheran. Teaching was highly unsatisfactory according to modern standards. Dissection was totally neglected due to its forbiddance by Mohammedan law. Because of fear of polluting earth and water, bodies of the dead were left exposed on a "Tower of Silence," to be eaten by birds. Cremation and burial were considered to be religious violations of the greatest magnitude. Contact with the dead was a great sin, resulting in contamination which required purification by washing with the urine of cattle. The people visualized a spirit of putrefaction, in the form of a plaguing gadfly, emanating from a cadaver. 


\section{$[\mathrm{XI}]$}

\section{THE RISE OF THE RESURRECTIONISTS AND THEIR METHODS IN GREAT BRITAIN-A.D. c. 1750 to 1832}

$\mathrm{T}$

he anatomizing of man has encountered the greatest difficulties in Great Britain and the United States. The medical profession, in these countries, has never been able to organize itself behind human dissection to the extent of publicizing or trying to exert pressure on individuals or administrations concerned with regulating the source of material. Few changes have been instituted on the basis of rational discussions. Rather erupting emotionalism of a high order has evolved in certain geographical spots and has been instrumental in producing some beneficial modifications necessary for the teaching of anatomy in a modern medical curriculum. Once things were relatively straightened out, the anatomical program has been conducted in a quiet and rather secluded manner.

Because of certain developments in the British Isles during the early part of the modern period, it gradually became the center of medical education throughout the world. Although latent in inaugurating a renaissance of its own, many British, medical men took their training in Italy or Paris; some came into contact with and were influenced by the outstanding anatomists and surgeons there. They observed the methods in vogue at these places and returned to their native countries with new ideas, which they were anxious to experiment with and possibly put into effect. Since anatomy and surgery were intimately associated with each other, the former serving as a handmaid to the latter, the individuals who were to carry the banner for anatomy in Great Britain were surgeon-anatomists. At an early stage, there were no professors who devoted themselves to full-time teaching 
of anatomy; all were practitioners as well, a system which was to last for many years.

From the standpoint of what viewpoints were accepted from the Continental system, no immediate innovations were made in the teaching of anatomy in the British Isles. The developments paralleled those in Italy in many respects, but they were eventually handicapped by less liberality in the dissection laws. Scarcity of cadaver supply was the outstanding feature during the 17th, 18th and first-half of the 19th Centuries. This became more acute and distressing when it was decided that medical students, who were increasing in numbers, should be extended the privilege of dissecting human bodies.

The sole legal supply of bodies by statute in Great Britain, until the early part of the 19th Century, was those of executed felons. Even though there were fewer medical students and relatively more frequent hanging of criminals, in the 1700 's, the subjects, which were obtained under the jurisdiction of the court, only partially satisfied the demand. What developed was an expanding interest in anatomy. This arose from a realization that the existing morphological knowledge was founded on insecure grounds, that it was based on equivocal tradition rather than on scientific considerations, and that ignorance of specific facts was retarding the whole of medicine.

The first reaction to this state of affairs was the introduction of secret dissections carried on in the homes of physicians, without the sanction of the guilds, of which they might be a member, and in violation of the law. It was obvious that a new source of cadavers had to be found, outside of executed criminals, and that there was another choice: the newly buried bodies in cemeteries and especially potter's fields. To obtain them, became a job for young apprentice barber-surgeons or physicians working in conjunction with gravediggers.

The name Potter's Field goes back to the time of Christ. After Judas Iscariot became repentant following his betrayal of Christ, he returned the thirty pieces of silver he had accepted to the priests of the temple. Because it was regarded as blood money, the clergymen decided that the money could not be put in their treasury. Instead, they ruled that it should be utilized to buy a plot 
of ground where strangers who died in the city of Jerusalem could be buried. Accordingly, they purchased an abandoned field for this purpose, land which had formerly been occupied by makers of pottery; it lay on the slope of the Mount of Olives. This eventually was bought as a place of public burial and the term potter's field has been widely used to denote a place for the interment of the poor.

During the latter half of the 18th Century, the demand for human subjects increased because of two factors: the appointment of full-time professors and the rise of private and hospital medical schools. The latter development was destined to play an important role in medical education.

This was made possible because of the manner in which the hospitals handled their new found privilege: it became evident to members of the profession that corruption, bribery and favoritism were being practiced in some respects, including the appointments of professors of anatomy. Because of this, certain surgeon-anatomists struck out for themselves and succeeded in establishing their own dissecting and teaching centers. This started a precedent which had widespread ramifications, because it paved the way for the entrance of more medical students. Among the pioneers in this movement were the following: Edward Nourse, Percival Pott, Caesar Hawkins and William Hunter. It was the last who introduced a new approach in anatomical pedagogy in Britain, in his school located on Great Windmill Street (Guttmacher, '35).

Flaming the conflict, was the requirement of the English government (Scotland and England were in union) which had half-heartedly sanctioned the aim of the medical profession for higher standards in anatomical proficiency. Medical standardizing agencies demanded that each student produce a signed certificate from the anatomy professor stating that he had fully attended two courses of lectures. The surgeon was also placed in a precarious position: he was required to have an anatomical background in order to practice his specialty. The statutes of his government provided but a few bodies from the gallows and made it a misdemeanor to disinter a corpse; such a violation was penalized by a moderate fine plus imprisonment of a few months. The 
recipient of a cadaver was placed in the same category as a grave robber so that every student or teacher could become involved. An odd feature of the law of James I was that it was not actually directed against the act of body snatching performed for the purpose of dissection; rather, it was aimed at preventing the use of bodily parts in witchcraft.

Another twist was added in the year of 1788, in the court case of the King vs. Lynn, when it was decided that resurrecting a human body did not constitute a felony since a corpse, by itself, did not represent real property. This decision had far-reaching significance since it established a forensic precedent which was copied later in other English-speaking countries, notably the United States. However, any part of the burial vestment was considered to be real property and, if removed, classified it as a more serious crime. The resurrectionists had enough intelligence to strip cadavers of habiliments and leave them in the coffin (Guttmacher, '35).

The following factual material is taken from the excellent article of Guttmacher ('35): removing human bodies from their graves became widespread throughout Ireland, Scotland and England and was practiced by two classes of men. On one side, were those who belonged to the medical profession, either surgeons, teachers or students. They were of a relatively high caliber, being well-educated men, who were interested in cadavers only from the scientific standpoint. Dissection of man was regarded as an opportunity to advance their knowledge, meet the medical standards imposed on them, make themselves better practitioners and thus serve mankind more adequately. In the early days of British medicine, it was the surgeons who, on a small scale, did most of the body snatching. They were careful in their selection, choosing bodies from fresh, unwatched graves. As the students increased in enrollment, they shared in the program either to the extent of organizing their own foraging parties or aiding others more versed in the art. This outside participation was necessary in order to obtain a supply to meet the needs which they had helped to create.

It was natural that the "gentlemen" body snatchers, as they were called, were unable to cope with the increasing demand for 
cadavers. To meet this challenge, there arose a group of individuals, who by contrast, were given the name of "rascals." They were made up of low-class rowdies, criminals, gravediggers and sextons whose ultimate aim was to make money at the trade. It did not take them long to commercialize the whole practice. They found it an exciting form of employment which required more brawn than brain, or at most what was needed was a crafty type of intelligence. At first, the men in this group were recruited from the laborers in the graveyard who were careful to hide behind the curtain of night for the transaction of their business; knowing the landmarks and working in secret they, in general, escaped notice. Others, of diverse ranking and personality, muscled-in on the profit making enterprise. The smartest among them organized others into gangs. At the beginning of the 19th Century, they operated in the form of unlicensed and unwanted guilds in all of the principal cities of the British Isles: London, Edinburgh, Glasgow and Dublin. They were not averse to invading every burial ground and cemetery in these urban centers; they also roamed far afield in rural areas looking for fresh bodies when the pickings were slight in the cities. Continued success and ever keener competition made them bolder in their methods.

The economic law of supply and demand worked perfectly in the gradually expanding resurrectionist enterprise. When the need was small, only a few men engaged in the traffic, and the price was pegged accordingly at 2 pounds, or less. After the number of students and teachers multiplied sixfold, creating a marked scarcity, extortion was employed and the cost of an individual cadaver skyrocketed to as much as 14 pounds; this, in turn, attracted more "rascals" to the trade.

During the early part of the medical renaissance in Great Britain, the building of anatomical and pathological museums was in vogue, in all quarters. Whenever an abnormal or unusual specimen presented itself, every attempt, which sometimes included subterfuge, was made to gain possession of it. Occasionally, a living individual with a diagnosed rarity, would be watched closely, with the idea in mind of trying to obtain his body after death. In this category, there seemed to be a fascination for the giants of the period. 
Connivance between surgeon-anatomists, resurrectionists and governmental officials occurred at even parliamentary levels. This does not mean that the body snatchers went about their work immune. It was usually an emotional outburst by a certain portion of the populace, precipitating mob action, which served as an impetus to the constables to make an arrest. Lodging in jail was made more to protect an individual or group rather than on a specific charge of misdemeanor. People were naturally touchy on the question of grave robbing and they organized quickly when their suspicions were aroused. One could cite a number of instances, where innocent funeral processions were attacked, horses removed from the carriage, the coach toppled over and the fragments burned.

When resurrectionists were caught in the act by the rabble, they were usually beaten severely unless saved by the police. Those who were apprehended, indicted and imprisoned, managed, in some manner, to inform the anatomists, with whom they were associated; if harmony existed between them, the culprits expected the professors to do all in their power to free them from police cross-examination and if necessary, furnish bail. In cases of incarceration, the schools usually took care of the families by putting the men on a livable salary during their servitude. Sir Astley Cooper, a London surgeon-anatomist, kept records of the sums he periodically paid out for bail and family support; sometimes he continued to finance such for as long as 126 weeks.

The teachers at the anatomical schools were also in an unfavorable position as far as the sack-em-up men were concerned. Their existence depended upon an adequate supply of cadavers, especially those anatomists conducting private schools. With the rapid increase in the number of students and anatomical establishments, competition became keener and the quantity of subjects received in any one institution, important. Before the beginning of a scheduled dissecting period, members of organized bands of body snatchers would haunt the anatomical establishments, either bowing and scraping or maintaining complete silence, depending upon the prevailing atmosphere. Their aim was to try and settle on as large a price per cadaver as possible for the ensuing session and even to demand an initial fee, if they could get 
away with it. Sometimes, preliminary financial sparring developed between the man in charge of the dissecting-room and the resurrectionists, rather than the professor and the latter. Eventually, the pedagogue might be informed indirectly that 50 pounds was being demanded before the professional body snatchers would agree to provide any subjects. This might be exacted under the guise that it was necessary to reimburse a watchman, whose assistance was required during the removals from the burial grounds. If a leader was successful in this extortionate plan at a half-dozen anatomical establishments, his gang was assured of getting off to a flying start.

The resurrectionists also worked on the other end of the line, that is, they demanded finishing money, or a bonus fee, to be paid at the end of the dissecting session. The amount demanded depended principally upon the quality of the services performed.

If the cadaver supply was shut-off, for any reason, the students would become dissatisfied; they might hold meetings deciding to send a delegation to the professor launching a complaint against the insufficiency. Threatening letters were also written anonymously by them stating they were planning on leaving for the Continent en masse or accusing him of inactivity, obstinacy and even parsimony.

The physical condition of a cadaver was of some importance in respect to the price paid. If a body was sold before it was buried, there was extra money in the seller's pocket. It was natural, therefore, that grave robbers would be on the alert to steal this type of specimen.

More frequently, however, the body snatchers were ultrawatchful for any dying person who was friendless, homeless and penniless. They would spend hours studying the history of each case and would even go to the extreme of trying to personify the one last spoken of by the deceased, which would allow them an entree into the death chamber, whether in home or hospital. Sometimes, this would be done by enlisting the aid of a female accomplice, without whom, it might have been impossible. They oftentimes took into partnership with them lower class undertakers whose task was to substitute clay, wood or stone in the casket, replacing the body. This involved fee-splitting. 
Stealing or purchasing bodies, in the British Isles, before interment, was not the most common way of obtaining them for purposes of dissection. This approach accounted for only about 10 per cent of the total. The remainder was acquired by the method of exhumation: from the churchyards, private cemeteries and public burial fields of the principal cities.

In cases where potter's fields were depleted of cadavers suitable for dissection, and there was a demand for them, raids were made on private cemeteries, which required much more effort and ingenuity on the part of the body snatchers. Walls were built around such graveyards and the tops littered with broken glass, loose stones or sharp spikes. The entrance gate was large, strong and padlocked at night. Watchmen might be hired by relatives to guard the new graves of their beloved ones or special iron grilles, called mortsafes, were made to surround the plot to prevent removal. The best plan the resurrectionists could try in such a case was to entice the sexton into their employ on a piecework wage basis: so much per subject raised. It wasn't too much of a chore for the caretaker to leave the gate unlocked, permitting easy entrance and it was a simple way for him to earn money.

Pilfered plots in private burial places, when found, were of much concern to the populace. Discoveries were made, not so much on the basis of ineptitude on the part of sack-em-up men but because of machinations and quarrels between rivals. Monopolies, which were recognized, were held by certain groups on different cemeteries; if violated by another gang, it meant a war of retaliation against the offenders: pulling up coffins in the competitor's territory, propping bodies up against walls or scattering the graveclothes. A hubbub would thus be created among the citizens resulting in a police investigation, which was usually fruitless in catching the culprits. Putting oil lamps in the burial ground and hiring a watchman were customary defenses but these almost inevitably failed because of successful bribery of the guard by the resurrectionists.

There was no such word as ethics among competing body snatchers; it was a cutthroat proposition for all concerned. The aim of each was to spoil the success of the other and further his own gain. Rival grave robbers sometimes made their weight felt 
in respect to the anatomical teachers or other buyers. If a pedagogue purchased cadavers from one gang, he risked displeasure from another; offended rivals might break into his dissecting-room and mutilate subjects to the extent that they were nonserviceable for further anatomical study.

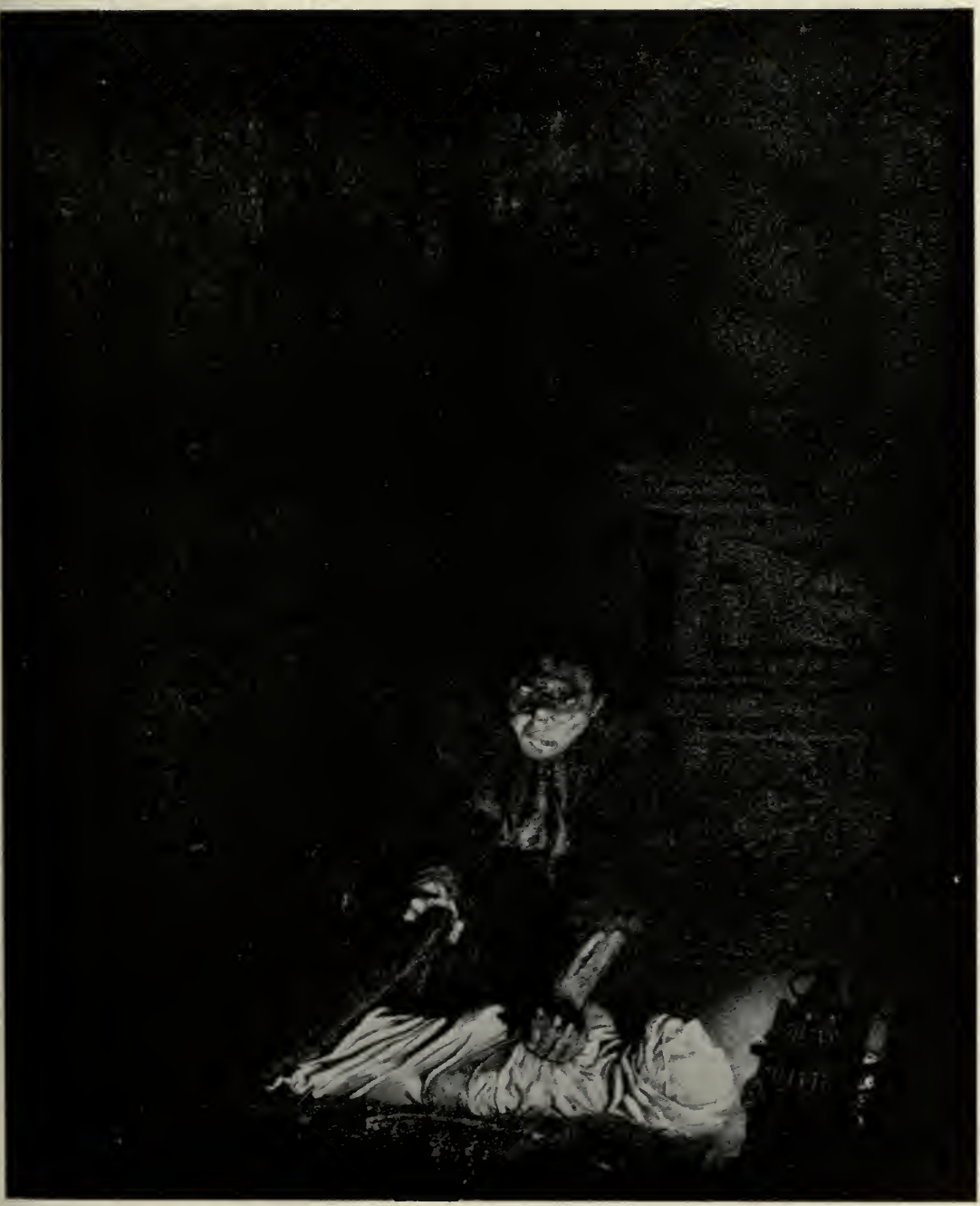

Figure 10. The Sack-'em-up Man. From a black-and-white drawing, "The Body-snatcher," by Meredith Williams. From Ball, J. M.: The Sack'em-up Men. London, Oliver \& Boyd, 1928. By permission of Oliver \& Boyd. 
In removing subjects from their buried coffins, deception had to be practiced and proper tools used by resurrectionists: sharp, curved spades with elongated handles, scoops on jointed shafts, grappling tongs and crowbars. The grave was not always exposed directly from above but sometimes at a slant. In the latter case, an amount of turf, about two feet square, was first removed, about 15 to 20 feet from where one end of the coffin was judged to be. This was carefully set aside to be replaced later. From this spot, a tunnel was dug leading to the end of the box; once reached, this part was wrenched off and the corpse pulled out through the passageway either by its head or feet; considerable effort was required for this task. The excavated portion was then refilled and the square of sod replaced to its original position. Since the mound directly over the casket was undisturbed by this approach, it was difficult for mourners, revisiting the cemetery, to discern foul play. When several bodies were buried together, as was done during an epidemic, it was necessary to excavate the entire plot. There were other methods utilized.

Concerned relatives, who were aware of the shenanigans of the body snatchers, tried to put identifying marks on the graves of their departed ones in the hope that they could detect possible interference. The grave robbers were on the alert for such telltale signs; when necessary to remove them in the line of their work, they were carefully restored to their former position. Every effort was made by regular gangs to keep the details of their trade a secret. It wasn't until the practice was effectively smashed that the various methods used came to light.

In the most respectable cemeteries, more elaborate precautions were taken to outwit body snatchers. Spring guns were employed but they never proved highly effective. Women, employed by gangs, were sent to survey the premises, generally at the time of a funeral, to note and plot the position of the pegs. With this information at hand, the culprits could easily locate the wires leading to the firearm, then remove the latter temporarily, and replace it in its exact previous position when their work was completed.

The most effective safeguards were the following: solid stone houses in which bodies could be kept until they decomposed, 
which required about three weeks during summer, and longer in the winter. They were then buried with the surety they were unfit for dissection. Such a type of construction still stands in the burial ground at Crail, located on the coast about twenty miles northeast of Edinburgh. Strong iron guards (mortsafes), which resembled a cage, were also used over some graves; the metallic guards were firmly set in a stone base. The time that it took to construct one of these protective gadgets tended to neutralize its usefulness as a body might be snatched before it was completed. The use of iron coffins constituted the best deterrent against the machinations of the resurrectionists. Although the lid could be easily broken by the blows of a sledge hammer, the noise which attended such an operation prevented its adoption.

The anxiety which pervaded the populace in respect to body snatching was taken full advantage of by the funeral directors of the period. They advertised that many hundreds of dead bodies would be dragged from their wooden coffins during the winter and used for anatomical dissection. To quote one of these from Guttmacher ('35): "The violation of the sanctity of the grave is said to be needful, for the instruction of the medical pupil, but let each one about to inter a mother, husband, child or friend say shall I devote, this object of my affections to such a purpose; if not, the only safe coffin is Bridgman's patent wrought-iron one."

It was possible for a clever group of four or five resurrectionists to unearth close to 400 bodies annually and readily dispose of them to the anatomical schools. The total income from such sales might amount to 1,500 guineas, about $\$ 7,665$. When divided, it made a sizeable yearly income, for each member, when considering the pound sterling evaluation at that time. This was outside of the money which could be made from a by-product, namely teeth. These were in great demand and commanded fancy prices (Ball, '28; Guttmacher, '35).

Sometimes, a cadaver would be delivered by a student intermediary, particularly when the populace was aroused over some recently discovered incident of body snatching. From a hide-out in his home, the subject would be transferred to school or hospital at a propitious time. A hired coachmen, in such an instance, might sense the situation, and threaten to drive the 
pupil to the door of the police station unless he was paid a guinea, an exorbitant fare.

Exportation of cadavers, from one city to another and from one country to another, flourished in the early 19th Century. Here again, deception was practiced, the aim being to camouflage as much as possible. Bales, crates, packing-boxes, piano cases and barrels were employed as containers for shipment, in each case, trying to simulate a certain class of goods.

The sale of human teeth, as a profitable sideline, has been mentioned. These parts were in demand although the porcelain tooth was invented in 1776; the latter, however, did not become widely used until after about 1825. Because dental science was in its infancy, the method of filling teeth was crude and inefficient and decay was, therefore, common. Plates and bridges were made of sound teeth extracted from corpses. When a cadaver, removed from its grave, was too decomposed for anatomical use, these parts were still valuable.

During the summer months, there was a lull in the trade of body snatching for two reasons: there was little demand for bodies at this season of the year and the lighter nights increased the chance of detection. When a full moon shone, the resurrectionists either stayed at home or drank in the taverns.

Although a rather constant state of adverse emotionalism existed, among the people of the British Isles, stimulated by the activities of the resurrectionists, it was not adequate or sufficiently well-organized to deter body snatching as it was practiced during the latter part of the 18th Century and the early part of the 19th. Even though mob violence occurred sporadically, it took events of a more inflammatory nature for a crisis to occur.

Mob violence invariably developed when murder was resorted to as a means of supplying cadavers for the anatomical departments. This reaction was not too unexpected when considering the type of individuals involved, lured by possible monetary gains and the seriousness of the crime. A total of eighteen known murders were performed in the British Isles, seventeen in Scotland and one in England, and they were accomplished by special methods to prevent detection. 


\section{[XII $]$}

\section{HUMAN DISSECTION IN IRELAND-A.D. 1590 to 1885}

$I_{1}$ human anatomy, in the United Kingdom, because it afforded an unlimited source of subjects, at least for a certain period. Responsible for this, to a large extent, was perhaps its economic status.

All of the early dissection was associated with the University of Dublin, or Trinity College, as it is also called. This institution was founded in 1591 by Queen Elizabeth. Some instruction was given there in medicine about 1597 and lectures were made a part of the course in 1628. Each candidate for a degree was required to attend three anatomical dissections. These must have been performed in private houses as there was no place for such work at the University (Macalister, 1884).

References are made to dissections having been made in 1672 and 1676 but the first public anatomizing of man was conducted in 1684. The body of a malefactor was procured by Dr. Patrick Dun and dissected by Sir Thomas Molyneux over a week's period; the latter also did the reading from a book entitled, Anatomy Epitomized. A skeleton was assembled from this subject (Cunningham, 1885; Macalister, 1884).

An anatomical theatre was opened on the campus of the University, during 1711, in an ugly old red brick building; it was the first of its kind in the British Isles; this was the same year that the Board of Trinity College decreed that each medical candidate should be examined in all parts of anatomy. Twelve months prior to these events, a chair of anatomy was founded at Trinity College (University of Dublin) (Cunningham, '03; Doolin, '51; Macalister, 1884). 
Some of the early teachers of anatomy at the University were Richard Hoyle, Bryan Robinson, Robert Robinson, George Cleghorn, his son, James Cleghorn and James Macartney, the last being the professor at the peak of the resurrection period (Macalister, 1900).

In Ireland, as elsewhere in Great Britain, surgeons and anatomists were vitally interested in obtaining abnormal specimens. One such incident is recorded where Professor Robert Robinson was involved in successfully attempting to secure a human giant by name of Corney Magrath.

The latter was a seven foot, nine inch man who died at the age of twenty-three, shortly after the year of 1741. Robinson, on learning that some of the members of his anatomical class, were intent on stealing the specimen, warned them that there was no law against taking the body itself, but that if they took so much as a rag or stocking with it, they could be hung. As was customary, a wake was held by the friends of the giant in quarters over one of the public houses. Four disguised students of Robinson's joined this session and immediately popularized themselves with the others by ordering a generous amount of whisky. To the drinks given to the nonmedical group, laudanum, an opium compound, was added in quantities to produce deep sleep. The students by prearrangement, signaled to other classmates planted close by, who appeared with a large door. On this crude structure, the body of Corney Magrath was placed, concealed with gowns, and finally transported with enthusiasm and triumph to the anatomical laboratory of their teacher.

The following morning, consternation reigned among the friends of Magrath, who though a bit woozy, were able to decipher the ruse. Accordingly, they marched to the provost of Trinity College, indignantly asking him for the return of the body of their friend. The perplexed official sent for Dr. Robinson who explained to his superior as follows: "My dear sir, such was the zeal of the young men that they commenced dissection at once, and it is now far advanced." The head of the institution, sizing up the situation, dickered with Magrath's friends money-wise and was able to settle the matter amicably. On returning to his anatomy room, Robinson was heard to say in a chuckling manner, 
"Divil a knife's in him yet." The anatomist was able later to give a public demonstration of the body of the giant, which was well-attended by the curious. This constitutes an incident concerned with the sale of a human body, not considered to be real property, where the payment of money triumphed over weak sentiment (Guttmacher, '35; Macalister, 1884, 1900).

In 1784, the surgeons of Dublin founded a school of anatomy which was attended by practically all the medical students in the city. For example, in 1797 , it had 100 pupils to only one at Trinity College (Macalister, 1900).

Of the four great metropolitan areas, in Great Britain, Dublin was in a class by itself. This was due to the fact that the incidence of paupers was very high in the city. The unemployed, vagrants, and beggars of Ireland infested the city, some looking for work, others hoping to be maintained without it. They inhabited the worst districts, helping to create density of population and filth, with an attendant, high death rate. Under these standards, it was a simple matter to supply an adequate number of cadavers for the medical schools (Guttmacher, '35).

The main source of human subjects in Dublin was the burial ground provincially known as Bully's Acre; its real name was the Dublin Hospital Fields Burying Grounds. For over a thousand years, it had served as the final resting place of the poor because no charge was made for interment. It made easy pickings for the resurrectionists because it was both unguarded and unfenced. A neighboring inn found it good business to keep picks and shovels on hand for the use of those relatives or friends who wanted to dig graves for their dead (Guttmacher, '35; Macalister, 1900).

It was natural that such a tavern was popular with resurrectionists, undertakers and hearse drivers, being a place where they could either watch or assist in the interments. Knowing the recent burial spots, it was relatively easy for groups to assemble at a common meeting ground and then almost openly pillage the newly made graves. The law enforcement authorities apparently wore blinders and tolerated the practice.

So plentiful were the bodies available in Bully's Acre that it was exploited for exportation purposes by resurrectionists. Fif- 
teen hundred to 2,000 were removed from it annually. Many were shipped out of the country at fabulous prices after the market had been cornered by a body snatcher named Wilson Rae, a Scotchman by birth. So expanded and profitable did this business become that it jeopardized the supply to the anatomical schools in Dublin, partly by raising the cost of cadavers beyond the financial means of the anatomists. The medical profession of the city officially protested against the exportation of subjects but not against the act of grave robbing.

The factors which made exportation of bodies from Dublin possible were the following: the introduction of steam navigation into the Irish channel, the augmentation of the number of medical students throughout the Isles, the scarcity and expense of bodies in England and Scotland and finally the abundance and comparative cheapness of them in Ireland.

Wilson Rae had been a half-pay surgeon, in the employ of His Majesty. His method was to bribe all parties concerned with commerce in human subjects, when necessary. He also purchased some from the porters of the anatomical schools, who became traitors to the cause, because they were paid weekly throughout the year to do all they could in keeping their institutions adequately supplied. It was necessary for Rae to enlist the aid of the resurrectionists, which he was able to do; he personally accompanied them on their forages to the cemeteries. All sense of decency was abolished; the graves, after being ransacked, were left open and bodies were transported from isolated depots, even at midday. The captain of the ship used in the transportation was also cut in for a share of the profits. Both Rae and his wife, were eventually arrested when they were caught shipping corpses in piano cases (Erinensis, 1829; Guttmacher, '35).

James Macartney, who had accepted the chair of anatomy at the University of Dublin in 1813 was exposed to mob action in 1826 , when the body of a well-known person was brought into his laboratory by a group of resurrectionists; the anatomist immediately buried the specimen, otherwise the ired people would have torn down the place. On another occasion, three body snatchers stole the corpse of a lady from the altar of a convent church and brought it to Macartney; when he learned the circum- 
stances, he made immediate arrangements with the clergy for its removal. This Irishman was of an unusual character in that he believed that the general antipathy against anatomy was based on false sentimentality and he started a one-man campaign to rectify the situation. Although he was well-supplied with subjects, he tried to educate the cultured people that there was nothing necessarily repulsive or inhuman in the study of practical anatomy and he encouraged the willing of bodies to the University; he met some success. Three hundred and fourteen persons put their signatures to an anatomical agreement of this nature about the year of 1827 . The anatomist was somewhat disappointed in this number as he had anticipated a thousand (Macalister, 1900).

Macartney was acclaimed by everyone as a teacher; combining enthusiasm, culture, genius and industry, he was judged to be an expert anatomist and philosophical biologist, far in advance of his period. He stored his mind with knowledge, not all learned from books, and exerted a marked and favorable influence on his pupils. By 1827, he had increased his classes to 200 , in spite of the fact that much of his early teaching was done in an old, wholly unsuitable edifice. Although a new structure was erected in 1825, he said, it was the "worst-devised building for the purpose," that he had ever seen. It had been constructed without suggestions from him. So popular were his courses that students came from England, Wales, Scotland and America, making up about one-sixth of his pupils. Many later became teachers. There were some who believed that he matched Robert Knox of Edinburgh in ability and might have been his superior. His one weakness may have been that he provided too much superintendence for the students. He demonstrated from dissections, divided his pupils into groups and emphasized that they should be mutually helpful. His teaching museum was kept open twenty-four hours a day (Macalister, 1884, 1900).

The quantity of bodies, obtained principally from Bully's Acre, though large, were not all available to Macartney. He was supplied by resurrectionists of whom there were about fifty in the business in Dublin, led by a person named Tom Geraghty. Macartney estimated that 600 to 800 cadavers were used during 
the 1826 season, in five Dublin schools, whereas Erinensis calculated 1,500 to 2,000 which probably overshot the mark (Macalister, 1900). The local Humane Society became so upset over the situation prevailing at the cemetery mentioned above, that it organized a successful campaign to collect money to provide it with guards. The best they could hire were of low caste and they began by selling disinterred bodies to the resurrectionists; the majority of such subjects were put in barrels and piano cases and shipped to Scotland. Nevertheless, by persecuting the body snatchers, the Humane Society was instrumental in reducing their number from fifty to twenty.

Macartney was likewise concerned about the unchecked raiding of the graveyards and in 1832 after the passage of Warburton's Anatomy Act, by the English Parliament, he petitioned this legislative body for a change in the laws, claiming the following:

1. Prejudices existed against the teaching of practical anatomy.

2. Anatomical students were unable to acquire the necessary knowledge or meet regulations.

3. There was increasing difficulty in obtaining dead bodies.

4. Crimes were committed because of the impossibilities of supplying laboratories in a legal manner.

5. An act was needed which should:

a. Honor dissection.

b. Discontinue the anatomizing of executed murderers.

c. Permit willing of bodies.

He advocated that all dissecting-rooms in the United Kingdom be closed temporarily.

According to Macartney, if these suggestions were followed, it would rectify the weak spots in Warburton's Anatomy Act, of August, 1832 (Macalister, 1900).

A number of private schools sprang up in Dublin during the last one-third of the 19th Century. The anatomists competed among themselves, showed little originality and were primarily 
Cyclopedists. The Crimean War (1854-56) between Russia and Turkey, with England allying herself with the latter, created an immediate need for Army surgeons. There was a rush of students into the medical schools, the standards fell to rock-bottom, cramming became the fashion and the grind rooms were overflowing (Macalister, 1884). 


\section{[XIII]}

\section{HUMAN DISSECTION IN ENGLAND-A.D. 1510 to 1958}

$\mathrm{O}$ ne of the first kings to do anything about human dissection in England was Henry VIII. When he first came into power in 1509, he granted the collegiate medical schools of Oxford and Cambridge the privilege of issuing licenses for medical and surgical practice. In 1512, he put all practitioners, except graduates of the above two academic institutions under the surveillance of the Church. Six years later (1518), he gave the Royal College of Physicians its first charter which declared that it could also function independently of the Church. The Barber-Surgeons Company, organized in 1540, was not left out of consideration, in this respect. Parliament and Henry VIII made it legal for them to obtain four bodies of executed criminals per year, to be used for dissection and teaching. Attendance was open to the public and compulsory to members; they were held with much pomp and ceremony.

The real founder of anatomy in England is considered to be John Caius (1513-1573). He was a native of Norwich, England and a graduate of Cambridge. His medicine was studied at the University of Padua, in Italy. It is possible that he may have been influenced in deciding on a medical career by Vesalius, with whom he lodged for eight months while at Padua. At least, he gave up a professorship in Greek there and made the change (Ball, '28; Guttmacher, '35; King, '18; South, 1886).

Caius returned to England in 1541 and was summoned by Henry VIII to give anatomical lectures to the London surgeons at the Barber-Surgeon's Hall. Through his influence, he was able to obtain the bodies of four executed criminals annually for the Company. He was instrumental in laying a solid foundation for 
anatomical study in this region during twenty years of teaching which included tenures at the Barber-Surgeon's Hall, the Royal College of Physicians and at Caius College, Cambridge. At the last institution, he was made master and it was given his name in 1559. After being appointed president of London College he continued to teach anatomy and became the personal physician of Queen Mary. He remained a Galenist to the end (Macalister, 1891; Macmichael, '23).

During the reigns of Edward VI (1547-1553) and Elizabeth I (1558-1603), students at Cambridge were required to attend two or three dissections before graduating. Here, the Regius Professor was forced to make, at least, one anatomy per year; failure to do so meant a fine, according to the law. In 1565, Queen Elizabeth granted four bodies annually to the College of Physicians and Surgeons. That there was some surreptitious dissection done in those early days in England, is suggested by the fact that a John Dean was fined for having anatomized in his home; this was in 1573 (Ball, '28; Guttmacher, '35; Macalister, 1891; Robinson, ’05).

Apparently, during the 16 th Century, some consideration was given to the accommodations for students and others. The BarberSurgeons built seats in their hall in 1567 to permit better observation; the competing Royal College of Physicians erected an anatomical theatre in 1583, and a second one in 1641 (Macmichael, '23; South, 1886).

Epitaphs on old tombs suggest that the practice of body snatching was in vogue early; Shakespeare wrote one in the 16th Century in one of his books as follows (Arey, '40; Guttmacher, '35):

Good friend, for Jesus' sake forbear

To dig the dust inclosed here;

Blest be the man that spares these stones,

And curst be he that moves my bones.

One of the outstanding figures in London during the latter part of the Renaissance period was William Harvey (1578-1657), who is better known as a physiologist than an anatomist. Nevertheless, he was prominent in anatomical circles during his period 
of medical training and gained the background necessary to solve the important question of the circulation of the blood.

Harvey was the son of a prosperous yeoman. He matriculated as a student at Caius College, in 1593, at the age of sixteen, and was given a six-year scholarship, the first ever presented for medical study. During his tenure, Thomas Grimston, anatomist, conducted two annual human dissections permitted by law, which Harvey attended. He undoubtedly took full advantage of his finanical support; he graduated with a degree in Arts in 1597.

After leaving Cambridge, Harvey went to Padua where he studied under the supervision of Fabricius ab Aquapendente and Casserius for four years. It was here that he became interested in the circulation of the blood largely because Fabricius was completing his anatomical observations on the venous valves, which he had discovered, but was unaware of their true functional significance. On returning to London, Harvey taught anatomy for some years at the College of Physicians and the BarberSurgeon's Hall. He is known to have held a public dissection every winter. During this time, he continued his investigations on the circulation of the blood and made many examinations of vivisected animals. In 1615, he announced his radical views concerning the vascular circulation and in 1628 they were published in book form in Frankfurt with the title, Exercitatio Anatomica de Motu Cordis et Sanguinis in Animalibus. It was seventy-two pages long. The treatise gives a very clear account of the research performed (Herringham, '32).

His experiments included studies on about forty different species of animals and led to the following conclusions:

1. The heart contracts actively and dilates passively.

2. Atria contract first and then the ventricles.

3. Blood is forced into the ventricles by means of contraction of the atria.

4. The atria have no pulsing power, the apparent pulsations being due to the blood inside them.

5. The heart is the organ which propels the blood. 
6. The blood passes from the right ventricle to the parenchyma of the lungs and then returns to the left atrium of the heart.

7. The amount and rate of passage of the blood from the heart necessitate most of the blood returning to the heart.

8. The blood returns to the heart through the veins.

Harvey disagreed with the ancient theory that the heart is not muscular. He was unable to explain how the blood is transferred from the arterial to the venous system but he proved that it is propelled by the mechanical action of the heart.

This investigator possessed a marked individuality, inspired confidence and was held in high esteem. His publication created a sensation and elicited great argument and criticism. He was moderate toward his adversaries but eventually won out over all opposition. Stricken with paralysis, he died at the age of seventy-nine.

In 1663, King Charles II permitted the Barber-Surgeons to dissect the bodies of six executed criminals per year. As early as 1674 , trouble was encountered in the acquisition of these because they were sometimes stolen and sold to the highest bidder. Soldiers commandeered the bodies of several who were publicly hung from the gallows, in 1706, which had been claimed by and were to be delivered to the Barber-Surgeon's Company. As many as 150 military men were in attendance; some of them cut the bodies down from the scaffold and absconded with them. The Company later asked the authorities for a special guard to protect their beadle, the latter being the person who was authorized to present credentials and take the corpses. Occasionally, the public interfered and took possession of such subjects. The combination of these events were such that they created a scarcity in cadavers making it necessary for anyone interested in dissection to turn to the resurrectionists for assistance (Ball, '28; Robinson, '05; South, 1886).

A Professor of Anatomy, John Rolfe, was appointed at Cambridge in 1707. No elaborate dissecting-place was provided for him; it consisted of a printing house which had been built eighteen years before and one of its rooms was shared with another teacher. 
Rolfe, apparently, was a poor choice; he developed a reputation for neglecting his duties and was warned of this in 1722; in 1728, the chair was declared vacant. One of the criticisms leveled against him was that a public anatomy was not held annually (Macalister, 1891).

William Cheselden (1688-1752), surgeon and writer, and a pupil of William Cowper (1666-1709), British surgeon, was called before representative members of the Barber-Surgeon's Company in 1714 to explain why he had been dissecting the bodies of executed criminals for three years in his home and teaching from them without the guild's consent. This practice, it was claimed, cut down the number of subjects at the Hall. Because of his gay and genial manner, which made him extremely popular with everyone, he was forgiven, but fined; he was then given permission to present regular lectures at his house and at St. Thomas' Hospital. Although he had plenty of opportunities, he made no outstanding anatomical discoveries. This decision, on the part of the Company, led to a gradual relaxation of their standards, which encouraged the establishment of private dissecting-rooms and schools. It made matters more complex by creating an additional demand for bodies and providing the impetus for body snatching. The dissolution of the Barber-Surgeon's Company in 1745 ended their monopoly of anatomical teaching which had lasted for 205 years (Ball, '28; Dobson, '51; Guttmacher, '35; Rolleston, '39).

Obtaining the bodies of executed criminals by legal methods, not only provided inadequate material but when all the costs were added up, it was relatively expensive. Money had to be doled out to various persons and for suitable equipment: for a horse, coach, coffin, funeral and a certificate; and to such individuals as sheriffs, two beadles and their assistant, one who washed the body, a minister, clerk, sexton, the bearers and a charwoman. The total might amount to as much as 16 pounds.

In addition to the dearth of subjects, difficulty was encountered in filling the posts of Master and Stewards of anatomy, men regarded as important in preparing bodies for both private and public anatomies who were assigned the duty of obtaining cadavers through legal sources. A new regulation, issued in 1734, 
required that a demonstrator of anatomy be appointed yearly. The duties of such a man consisted of assisting the Master and Stewards, and demonstrating one private and one public anatomy per year.

Notices of public dissections had to be published in the daily newspapers but this requirement was discontinued in 1742 (South, 1886).

That the schools were concerned with the resurrection of human bodies is indicated by the fact that the University of Cambridge issued an ordinance forbidding grave robbing by members of their anatomy classes but this did not prove to be effective for the practice increased, if anything (Macalister, 1891).

The Barbers and Surgeons parted company in 1745; the latter built a new anatomical theatre in 1753 and installed it with a Professor of Anatomy, a Henry Watson. He was given an annual salary of 120 pounds and was required to teach anatomy three times a week throughout the year (Ball, '28; Rolleston, '39).

An important event in London was the rise of two hospital medical schools, St. Bartholomew and St. Thomas, which helped lead to the separation of the austere and pompous Barber-Surgeons. The latter, which imposed rules of its own, had to relinquish its long held right in regulating the teaching of anatomy. It could cope with individual violations of its code, but against these powerful institutions, their protests were futile.

From the descriptions given, it is apparent that the standards in dissection in the first hospital medical schools, were not very high. The students at St. Thomas were subjected to a small room of the following kind: in the daytime, light was obtained from two eastward windows; in the night, a square lantern provided the illumination. Glass cases, stacked from top to bottom, occupied the western part of the chamber. On the south side, was a large fireplace and a copper kettle which was used to prepare the subjects. In addition, a large leaden sink, placed under the windows, was used for washing hands and dumping debris. A dozen tables, which held the subjects were scattered about. Six to eight pupils were assigned to each so that a total of seventy to eighty were present at one time allowing barely enough space for each to 
move. Filthy linen dissecting gowns that never reached the laundry were the accepted apparel worn (Guttmacher, '35).

Courses were presented twice yearly, beginning the first of October and January 20th. A 10 guinea fee was paid by the student for the privilege of dissecting and another 10 for attendance at lectures. In the latter, discourses were given on general anatomy, the bones and the head (Guttmacher, '35).

In order for a hospital or other recipients to obtain the body of an executed criminal about the year of 1748, it was necessary to meet the criteria prescribed by law. A hanging, the common method of execution, was ordinarily scheduled for Monday morning at eight o'clock and the cut-down at nine. In London, the latter was performed by a man named Calcraft, alias Jack Ketch. When death was announced, the body was placed on a large cart with collapsible sides and taken to 33 Hosier Lane, in West Smithfield. It was accompanied by the City Marshall, wearing a typical cocked hat and ornate habiliments. At this address, the president of the College, members of the court and sometimes special visitors were assembled. The clothes and fatal rope were removed from the subject. The stout cord, used for the execution, was kept; it was worth money because it could be exhibited to the morbidly curious at the public houses for so much a view. It was required that the City Marshall be in attendance and properly witness the anatomizing. He made the ceremony as brief as possible; a superficial incision in the chest sufficed; following this, he beat a hasty retreat, riding his gaily decorated charger to report to his superiors that the procedure was properly discharged according to statute. While doing this, the opening in the cadaver at 33 Hosier Lane, was stitched; the corpse was then removed by an old museum attendant, named Pearson, in a light cart to the hospital to which it was allotted (Guttmacher, '35).

Although a number of private anatomical institutions were opened during the early half of the 18th Century, it was the development of a school in London by William Hunter (1718-1783) which was most noteworthy. This surgeon-anatomist was instrumental in inaugurating dissection by the students in the United Kingdom. He had visited Paris to study the French methods and had noticed that parts of cadavers were dissected by class mem- 


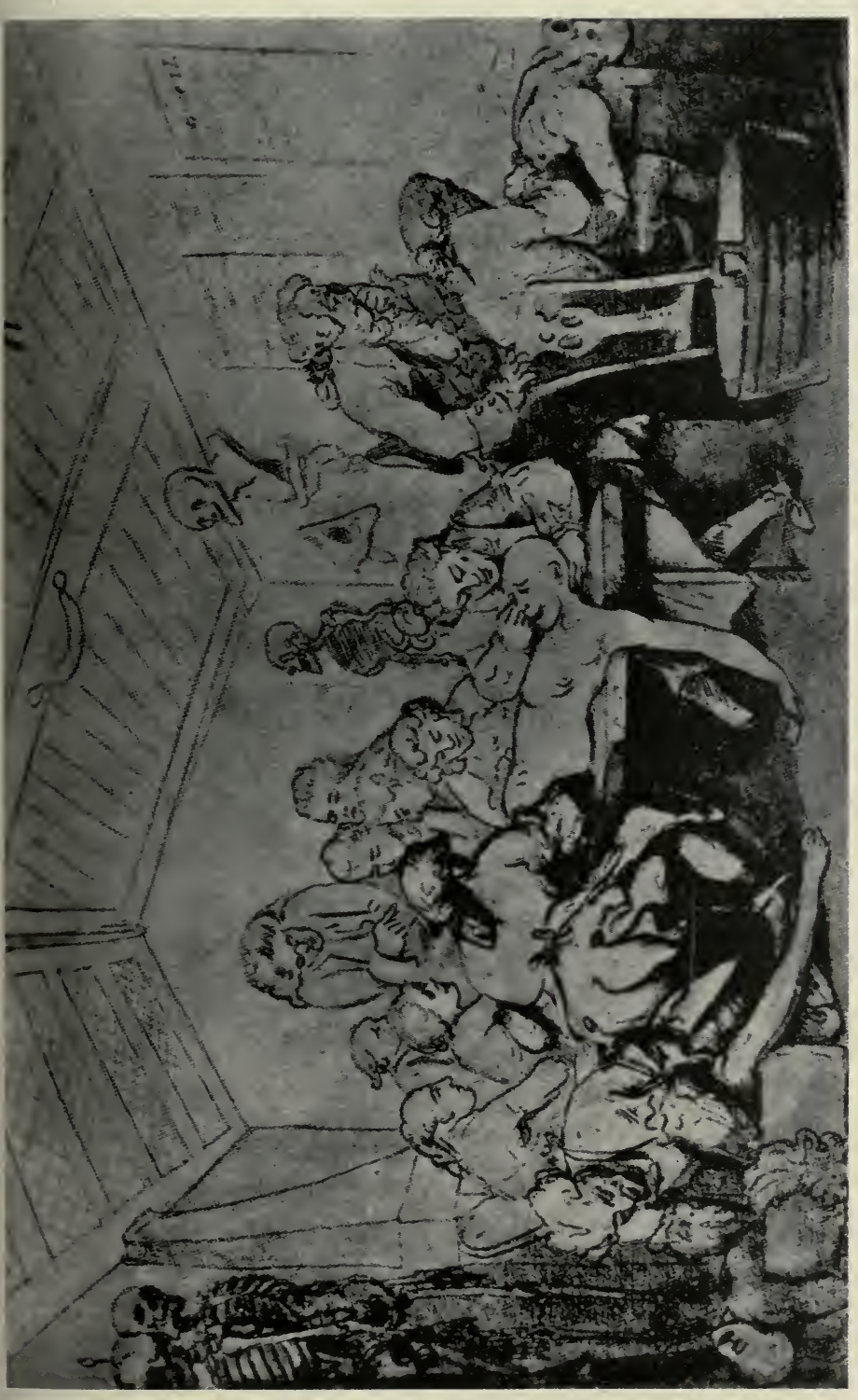

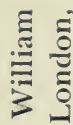

$\because$

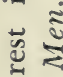

$\stackrel{5}{5}$

० हิ

ปั

ㅇ

60

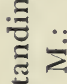

क

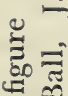

Е छ

玉. $\dot{0}^{2}$

ปี

$\frac{\pi}{3} \pm 0$

$\stackrel{000}{0}$

a

है

60.0

氙 $\cong$

के के

$\cong \stackrel{2}{=}$

는

. $\cong$

$=\ldots$

บ

恼恣 
bers. Previously, he had trained both under William Cullen at the University of Glasgow and William Smellie in London. He started his classes in October, 1746, advertising in the newspapers under the title: "Learning the Art of Dissecting." Two years later, he was joined by his brother John (1728-1793), who possessed a genius for experiment and observation which eclipsed that of his brother. For eleven years, the pair taught anatomy to huge classes, before a misunderstanding developed between them.

William Hunter is classified as the first great teacher of anatomy in London and one of the great surgeon-anatomists. He also carried on an obstetrical practice. His school was located on Great Windmill Street. Eventually, in 1768, he built his own laboratory and worked there until his death. One of his outstanding accomplishments, was to create a famous museum, on which, it is estimated, he spent half-a-million dollars. He was an early riser, a man of untiring energy who never married. Numerous papers were published by him and some were based on original anatomical observations. Hunter's ligament, gubernaculum, line and membrane were named after him. John was disinherited by his brother William before the latter's death. John refused to offer to bury his brother and on April 4, 1783, London newspapers requested that all of William Hunter's students each deposit a guinea at a specified bank in order that he be given a proper burial. In a will made thirteen years before, William had bequeathed both his anatomical establishment, including his museum and 8,000 pounds, to the University of Glasgow.

John Hunter also possessed untiring energy, industry and perseverance and was the founder of comparative anatomy.

Because the Hunters used the standards of student dissection, they helped to create a further demand for cadavers. In 1748, they had 20 students; in 1756, 100 (Brash, '30; Elliston, 1900; Mettler, '47; Packard, '37; Rohrer, '14; Rolleston, '39).

One of the prized possessions today, in the famous Hunterian Museum, housed in the College of Surgeons, London, is the skeleton of the Irishman O'Brien. Guttmacher ('35) gives its height as seven feet seven inches, Ball ('28) as eight feet four inches. The death of this man in London in 1783 apparently caused a sensation. The newspapers of the day were alive with 
excerpts revolving around it and particularly in respect to the efforts of the medical profession to obtain the corpse. The three below are quoted from Guttmacher ('35):

June 7, 1783: "The whole tribe of surgeons put in a claim for the poor departed Irish giant and surround his house just as Greenland harpooners would an enormous whale."

June 7, 1783: "Since the death of the Irish giant, there have been more physical consultations held than were ever convened since King Henry the Eighth was in existence. The object of these Aesculapian deliberations is to get the poor departed giant into their possession, for which purpose they wander after his remains from place to place and mutter more "fie, foh and fums" than were ever breathed by the whole gigantic race when they attempted to scale heaven and dethrone Jupiter."

June 13, 1783: "The Irish giant requested in his last moments that his ponderous remains should be thrown into the sea in order that his bones might thus be placed far out of reach of the chyrurgical fraternity. In consequence of which the body was shipped aboard a vessel last night in order to be sunk in 20 fathoms of water. The body hunters, however, are determined to pursue their valuable prey, even to the profoundest depths of the aquatic regions, and have, therefore, provided a pair of diving bells with which they flatter themselves that they shall be able to weigh the hulk gigantic from its watery grave."

Although the proper ceremony was performed by a duly authorized undertaker and the coffin was thrown off the chartered vessel in waters at the prescribed depth of 120 feet, John Hunter was able to direct the body of this mammoth specimen to his private cherished collection. The funeral director was bribed with 500 pounds, worth $\$ 2,500$ in that day, a staggering price. While the escorts, on their way to the ocean, stopped at an inn to indulge in some drinking, the coffin was locked in an adjacent barn under the guise of safety. A paid accomplice of Hunter removed the body from the receptacle, replaced it with an equivalent slab of paving stone, and that night transported it to the museum. The distinguished anatomist, distrusting its presence there, took it in his own carriage to his home in Earl's Court. Once there, the body was immediately immersed in boiling acid which de- 
stroyed identification and removed the flesh. One disadvantage of this procedure was the brown discoloration of the bones which remains to this day. Many individuals have had a view of the skeleton of the giant, O'Brien, placed vividly in the background of the famous portrait of Hunter by Sir Joshua Reynolds.

That some attempts were made to make the dissecting environment seem favorable is indicated in a public advertisement of Joshua Brookes in 1814, a proprietor of one of the largest of the private schools. He mentioned spacious apartments, thoroughly ventilated and replete with every convenience, including private chambers for the gentlemen established in practice, who desired to renew their anatomical knowledge.

Joshua Brookes was classified as one of the best private teachers of practical anatomy in London and was a character unto himself. To mention his oddities and possible shortcomings first, he is described as one of the dirtiest professional men ever seen by some of his contemporaries. In the laboratory his hands and wearing apparel were always filthy and he utilized his fingers in constantly conveying snuff to his nose; as a result, this part of his anatomy was invariably soiled. It was always a surprise to his friends to see him immaculate, not only because of its extreme rarity, but because he emerged as a new person: pleasant, dressed in black, with powdered hair, presentable hands, good manners and well-informed on conversational matters. However, in this circumstance, the snuff habit was as evident as ever (Guttmacher, '35; Rolleston, '39).

In spite of these traits, Brookes' School, located on Great Marlborough Street, attracted a large audience of students, considerably more than the hospital institutions. Part of this was due to the fact that his establishment was open the year round. He was one of the pioneers using embalming as a means of preservation, which enabled him to conduct a summer course; the formula he kept secret. The only other method then available was by salting, which was grossly inefficient. In some cadavers, he injected the arteries with hot wax in order that they might more easily be followed in anatomizing but for these specimens the dissecting fee was increased by one guinea (Guttmacher, '35; Rolleston, '39; Wakley, 1829). 
As an anatomist, Brookes had numerous dealings with resurrectionists and sometimes became caught in a cross fire between two rival gangs. In one instance, a disgruntled group tipped-off the authorities that he had a stolen body in his laboratory; it was removed by the police. To indicate the feelings of the populace, the officer who conducted the investigation, was given a silver staff by grateful citizens, the money having been obtained by public subscription. Brookes lost 16 guineas on this development, which he had paid to the body snatchers who had first contacted him and made the sale. Another incident which involved him is the following: having failed to pay an honorarium of 5 guineas to a group of resurrectionists who had demanded it before promising to deliver cadavers, two putrid bodies were dumped at night by them near his anatomical laboratory. The law enforcers were notified by two horrified young ladies who had stumbled over them; this affair aroused such a commotion among the citizenry that an angry mob collected and had to be halted by the constables, who in this situation, were on the side of the anatomist.

Brookes was probably the only teacher who ever had a live body sold to him as a cadaver. One night, during his active career, he was awakened by a man who informed him that he had a subject for him. "Bring it in," said the anatomist. This was done; Brookes making a partial payment, told the seller to come back the next day for the remainder of the money. He then gave the bundle a strong kick. which sent it tumbling down stairs to his dissectingroom. As he turned to go, he heard sounds emanating from the parcel. Without fear, he descended the steps to investigate and found a man standing there erect and confused. When Brookes accosted him, the individual begged off, complaining that he had been put in the bag when drunk. The anatomist accepted this as a trumped-up story and kicked the man, this time, out into the street. Later he analyzed the situation thusly: the man was primarily a housebreaker who had gained entrance in this manner for the intent of thievery; he had not forecast that he would be catapulted down a flight of stairs (Guttmacher, '35).

Since autopsies were not permitted during the early modern period in England, surgeons who were anxious to check the effect of operations performed months or years before, had mainly one 
recourse, and that was the resurrectionists. In 1820, Sir Astley Cooper, one of the most famous surgeon-anatomists of his time, paid over 13 pounds to two, Hollis and Vaughan, for making it possible for him to examine the body of one of his patients, whose iliac artery, he had ligated twenty-four years before. The subject had been buried in Beecles, County of Suffolk. The payment involved money for a coach, guards and coachmen, expenses for two days, a carriage and a porter for the return transportation and finally the amount paid over to the pair who exhumed the body. It was not unusual for a surgeon to dispatch suitable men a distance of 100 miles or more for such a purpose, making it an expensive post-mortem examination. Even the physicians, were not averse to venturing forth to satisfy their curiosity about operations previously performed. This took time, travel, risk and money, let alone the disagreeableness encountered in handling the body.

Sir Astley Cooper is mentioned in the previous paragraph. Probably no other surgeon of his time performed more anatomical dissections or had more familiarity with exhumators. He began anatomizing at the age of sixteen, in 1784, under the jurisdiction of Henry Cline, surgeon and teacher of anatomy, at St. Thomas' Hospital in London. The class was so large, the available space so cramped, which Cooper disliked, that he got permission from his teacher to transfer cadavers to the latter's home where he worked at his leisure, sometimes far into the night. He possessed an extraordinary zeal for such study and later continued the practice daily in his own residence even after he was internationally recognized as a famous surgeon for his accomplishments at Guy's Hospital.

The peak of the resurrectionist movement was between the years 1800 and 1832 and it was during this period that Sir Astley Cooper was most active. He appeared before the special Parliamentary Committee at the time this legislative group was considering passage of an anatomy act. He had a low opinion of all body snatchers classed as the "rascal" type and so testified. Quoting him, "They are the lowest dregs of degradation. I do not know that I can describe them better; there is no crime they would not commit, and, as to myself, if they would imagine that 
I would make a good subject, they really would not have the smallest scruple, if they could do the thing undiscovered, to make a subject of me" (Cooper, 1843; Guttmacher, '35).

Many eerie episodes occurred in those days when the practice of grave robbing was at its height. Four parties, in particular, were interested in the nocturnal events which transpired: the relatives or friends of a newly buried deceased, the resurrectionists, the anatomists and the police. The evidence indicates that the last tended to be rather tolerant with the ones most concerned, the thieves and medical men; the law might even be sympathetic, lenient and connive with others on occasion. This was true in the case of Sir Astley Cooper. Without this contingency, it is very likely that anatomical teaching would not have survived in England. The incident described in the succeeding paragraph demonstrates the cooperation between Cooper and a high-ranking official, the Lord Mayor of London. It occurred in the year of 1801.

By mutual understanding between hospital authorities and resurrectionists, it was forbidden to deliver the subjects they unearthed directly to the dissecting-room. This policy had evolved because of certain disagreements between the hospital porters and the sack-em-up men. The solution which was adopted, to ease the friction, was to have the bodies deposited in large baskets at night in the courtyard of Cooper's home situated in St. Mary Axe. From here, they were transported to the anatomical rooms at St. Thomas Hospital via coach, under the supervision of a man named Butler.

One night while Butler was in charge of delivering three specimens, he was apprehended by the police. He slipped out of the carriage, returned quickly to report the incident to Charles, the doorman of Sir Astley Cooper, who immediately conveyed the message to his master. When the policeman appeared he insisted on seeing the doctor. He was not able to get much satisfaction out of the surgeon, who claimed that since the gates were always left open until 11 P.M., he could not be responsible for any parcel that might be deposited in his private hampers or for their removal by anyone before that hour. The officer left, claiming loudly that he was going to report the matter to the chief magistrate, the Lord Mayor himself, early the next day. Cooper 
considered the matter importaint enough to arrange a meeting with the first ranking official of the city for the following morning. While breakfasting, the mayor listened to the transaction of the previous evening, with interest and attention, and then assured the surgeon that he would not be troubled further (Cooper, 1843; Guttmacher, '35).

The following cites an incident as to how a well-known London resurrectionist named Patrick handled an opportune situation to his satisfaction and profit. While sauntering in neighboring Sydenham, he learned that the body of a female had been found the preceding evening in an adjacent canal and removed to a public house. He went at once to the inn and learned from the potboy there that it had been placed in the stable to await examination by a coroner's jury, that it was thought to be an escaped pauper from the Woolwich workhouse, that it seemed to be unclaimed for burial and that no person had been selected to watch over its safety. This was all he needed to know. He took the opportunity of examining the size and form of the keyhole of the barndoor and then left for London.

Along with a companion, Patrick returned to the scene at a late hour the same night with a large bunch of keys. With unusual luck, the first one chosen opened the door, following which, the pair speedily removed the prize to their hidden cart, and then proceeded to London via an obscure and narrow lane. They succeeded in depositing their bundle at an anatomical laboratory sometime before daybreak. The resurrectionist returned to Sydenham the next afternoon; there, he heard a firsthand account of the commotion which had occurred that morning when the coroner's jury appeared to make an examination of the body and found it had disappeared.

Even the bodies of the well-to-do could be spirited away by clever grave robbers and Patrick was such. On one occasion, he was informed by an intimate friend, that the latter's employer, who lived a short distance from London had died. The informant thought that there was a chance to do some business because of the physical situation of the premises. Patrick investigated the possibilities, agreed and decided on a plan of attack. The funcral was to be held on Sunday and he calculated that the lid of the 
coffin would be screwed down tightly on Saturday evening. If it were, he wanted to be notified and he would not take action unless it was done. The cover was fastened as he predicted.

Late, on Saturday night, Patrick was admitted to the parlor by his associate. Without the aid of a light, the screws binding down the top of the coffin were released. After the body was removed, a carefully calculated amount of earth, obtained from the garden, was substituted. The lid was replaced and attached, following which, the black velvet funeral cloth was thrown over the casket. The subject was transferred to a crude box, passed out of the window, and hidden in a tool house some distance from the premises. The pair witnessed the entire ceremony, from the sidelines, and saw that their plan had been successful, working without a hitch. On the day after the burial, the stolen specimen was transported to one of the private anatomical schools; Patrick received the handsome sum of 15 guineas, or more than $\$ 75$, for the subject (Guttmacher, '35).

An instance is cited by Lonsdale (1870), in regard to the dangers incurred by surgeons who attempted to capture the body of a hanged criminal for the purpose of making a subsequent dissection. This particular incident occurred about 1830 in the city of Carlisle, England, located adjacent to the Scottish border. Friends of the condemned culprit laid in wait for the medical men, determined to revenge themselves if the body was touched. In the ensuing events, the doctors were seriously injured. A Dr. Anderson was shot in the face and carried the marks inflicted to his grave. Another surgeon was found dead, by the side of a bridge, his body having been thrown over the railing. Apparently, these defenders preferred seeing such a man hanging in chains on a public road, certain to be devoured by vultures, than being anatomized by doctors for the advancement of medical science. This caused great excitement, particularly to Lonsdale, since the shooting occurred about 100 yards from his father's door.

By 1828, London had eight private and four hospital medical schools. In addition to St. Bartholomew and St. Thomas, previously mentioned, there were two other hospital institutions: Guy's and The London. The larger private ones were the following with their owners: Webb Street School, Mr. Grainger; Aldergate 
School, Mr. Terrel; The Great Windmill Street School, Caesar Hawkins and Herbert Mayo, and the Blenheim or Great Marlborough Street School, Joshua Brookes (Guttmacher, '35). In addition, there were also several fly-by-night places, diploma mills, which tried to teach anatomy without benefit of theatres, museums, libraries or dissecting-rooms. Eight-hundred bodies were needed annually to supply the students matriculated in these medical schools. There was competition between them because there was money to be made in the teaching of gross anatomy.

With the great increase in the number of medical students, who were required to anatomize in Great Britain, it is obvious that the supply of cadavers obtained through legal means was highly insufficient. Between 1805 and 1820, there were 1,150 executions in England and Wales, an average of less than eighty per year. There were an average of 1,000 students present annually in London alone (Guttmacher, '35; Wakley, 1829).

In 1828 there were 800 students in London, with 500 dissecting on 475 available bodies, most of which were acquired illegally. Ten resurrectionists were regularly employed; 200 others were occasionally involved. The average price of subjects was four guineas (Bailey, 1896).

The following year, two anatomical schools located in the West End of London and those in Sheffield, Bristol, Liverpool and Manchester closed due to lack of bodies. Even at this late date, the whole city was invited to attend public dissections (Editorial, 1829).

The private anatomical schools, which were in the majority, and which for the most part were conducted by the ablest teachers, were not too popular with some of the standardizing boards. The Royal College of Surgeons passed a bylaw in 1824 requiring that attendance at anatomy sessions be compulsory and that certificates verifying this, be signed by an appointed anatomy professor in the universities or a person teaching in an acceptable medical establishment. This was unsuccessful in eradicating the private institutions because the organization was apparently losing stature in the profession. Its charter was temporarily abolished because of monopolistic policies (Ball, '28; Sprigge, 1897; Wakley, 1829). 
Not all the bodies unearthed by the resurrectionists around the London area were sold to anatomists within the city. Some were shipped to other parts of the United Kingdom. In 1826, three casks were found on Georges' Dock, Liverpool, labeled "Bitter Salts," which were consigned for shipment to Edinburgh. They remained there overnight and the following morning, the stench attracted attention. The police who were notified, made an investigation and found eleven dead bodies contained therein, salted and pickled. The source of these was traced to the rear of the home of a Reverend McGowan. Four other similar barrels filled with subjects were found; there was additional incriminating evidence. No marks of violence were found on any. When the minister was questioned by the mayor of the city, he was surprised; he defended himself by saying that he had rented the cellar to a man named Henderson who was supposed to be an oil trader and that he was totally unaware of the true nature of the situation. The specimens were buried in the parish cemetery, as they were found, and the resurrectionists responsible were never apprehended.

There were certain outstanding members of the medical profession who had been trying to impress the government for an alteration of the law, which they considered weak: such men as John Abernethy, Charles Bell, Everard and Benjamin Home, Benjamin Brodie and Astley Cooper. Largely through their efforts, they interested such distinguished individuals as Henry Warburton, a member of the House of Commons, and Thomas Wakley, editor and founder of Lancet. The influence of this group was largely responsible for the formation of a select committee in the House of Commons in 1828 to make inquiries into the possibility of legalizing dissection.

Surgeons, anatomists, police and resurrectionists testified at this preliminary session. The Burke and Hare murders in Edinburgh (cf. Chapter XIV) prompted Mr. Warburton to introduce his Anatomy Bill in Parliament; it passed Commons but not the House of Lords. It contained some of the following stipulations: all bodies were required to be buried after use, but it contained no provisions for Christian rites nor was it clear on the licensing of schools. Resurrectionists who were apprehended 
would be sentenced to six months imprisonment; for a second offense, the time would be increased to two years. Unclaimed bodies from the workhouses and hospitals would be turned over to anatomists seventy-two hours after death. Willing of bodies was legalized but the final disposition had to be decided by a legal executor. A major flaw was a failure to repeal the law that executed murderers must be dissected (Guttmacher, '35). Another impetus was needed to thoroughly activate the parliamentarians. This occurred in England.

The specific incident revolved around the disposal of the body of a fourteen year-old lad in London, by two men named Bishop and May. They appeared on the premises of King's College, on November 5, 1831, and asked Hill, the porter, if the medical school needed a cadaver. Assured that one could be used, they informed him of the age of the subject, and asked 12 guineas for it, sight unseen. Eventually, they agreed to take 9 . That afternoon, they returned, with another man named Williams, and the boy, who was in a hamper. The assistant, on seeing the corpse, suspected foul play, and immediately communicated his distrust to his superior, Mr. Partridge, the demonstrator in anatomy. The teacher examined the body and he likewise, was of the opinion that something might be amiss. He felt that the police should be notified, and, in order to detain the resurrectionists, he produced a 50 pound note, which he said would have to be changed before he could reimburse them.

The officers of the law were notified and when they arrived they took the trio into custody. It did not take long to ascertain that the subject was that of an Italian boy, one Carlo Ferrari, who had eked out a living by exhibiting white mice; his teeth had been extracted and sold to a dentist by the name of Mills for 12 shillings. The story came out in the confession of Bishop and Williams. They had lured the youngster to their dwelling in Nova Scotia Gardens where he had been drugged with opium and his body lowered into a well, where he suffocated. In their written statement, they also admitted the additional killing of a woman, a Fanny Pigburn and another boy, whose name they gave as Cunningham; both had been sold to the medical schools. This brings up the question as to how many murdered bodies may actually 
have escaped detection. Some writers believe that the number may have been considerable.

The offenders were judged guilty in court proceedings; Bishop and Williams were hung on December 5, 1831, whereas May was given transportation for life. The trial, with its attendant revelations, constituted the last straw in the chain of events. The legislators now hurriedly met to see what could be done about the enactment of a satisfactory law which would prevent similar criminal acts.

A second bill was introduced by Mr. Warburton, which received a majority vote in both houses; it became law on August 1, 1832 and since has been known as the Warburton Anatomy Act. It had the following provisions: it

1. Repealed the law making it compulsory to dissect the body of an executed murderer.

2. Created a supervisory board of inspectors.

3. Made any body, unclaimed forty-eight hours after death available for anatomizing providing the person had not expressed a desire, during his final illness to be properly buried.

4. Allowed persons to will their bodies if their nearest of kin did not object.

5. Made obligatory the burial of the dissected remains with religious services.

With this enactment, body snatching and the resurrectionists ceased to exist in the British Isles (Bailey, 1896; Frank, '07; Guttmacher, '35).

Although the Anatomy Act of 1832 may have put an end to body snatching, it did not serve as a cure-all for the cadaver question. A scarcity of subjects has been reported at various times in Britain: in 1887, 1914, and 1957. In 1957, the schools of Cambridge, Liverpool and Newcastle were not obtaining enough subjects whereas others were. The University of London needed 448 over a two-year period and got 474 . The provincial schools and Wales wanted 514 for two years and received 621 . The supply fell off between 1947 and 1957. At the University of London, 52 per cent of the bodies during that decade were bequeathed (Editorials, 1887, '14; Foreign letter, '57). 


\section{[XIV]}

\section{HUMAN DISSECTION IN SCOTLAND-A.D. 1500 to 1958}

$\mathrm{O}$ all the countries of Europe, it was Scotland which developed the deepest, most lasting, unchanging traditions in anatomy. From the beginning, major significance was attached to its importance and it has always been treated accordingly in the medical curriculum. It was there that the biggest emotional and dramatic incidents in the history of anatomy occurred. In Scotland, as in England, there was no immediate enactment of the laws which had worked successfully on the Continent, especially in Italy.

Whatever anatomical codes were initially formulated in Scotland, they were such that they provided a minimal number of cadavers. For an interval of 200 years, between 1505 and 1705, nothing much was done in anatomy. The people of Scotland, at least many of them, were concerned with theological disputes and destruction of witches. The center of medical activity was Edinburgh. A charter was granted there to the Guild of Surgeons and Barbers granting the privilege of dissection, as early as 1505 . The body of one criminal per year was allowed which apparently increased public horror of dissection; it had a retarding effect upon the practice for about three centuries (Ball, '28; Comric, '22; Creswell, '14; Guttmacher, '35; Watson, '36).

Annual demonstrations were presented by master surgeons of Edinburgh until 1645. At this time, a teacher, John Borthwick, was appointed to fulfill this duty. He was the first teacher of anatomy in that country. Before this, the craft met in doctors' homes but, thereafter, held classes in rented rooms. Due to the efforts of Borthwick, the students were required to take exams in anatomy in 1647 (Ball, '28; Comrie, '22; Creswell, '14).

A human skeleton was presented to the Town College of Edinburgh, by Dr. Michael Young, in the year 1671. It was as- 
sembled from the body of a young Frenchman which the physician had obtained while in Paris. This, apparently, excited awe and wonder (Ball, '28; Lonsdale, 1870).

There is some evidence that one of four gypsies, who were condemned, hung and buried in a single grave, was stolen by a surgeon for the purpose of making an anatomical dissection, in the year of 1678, in Edinburgh.

In 1694, the Town Council of Edinburgh gave permission to the Royal College of Surgeons of that city to use the bodies of foundlings, suicides, executed criminals, those dying in correction houses and stillborns. The stipulation was made that an anatomical theatre must be erected within three years and one public dissection held annually. The Royal College accepted the terms and had the building completed by 1697 . There was some delay in making the initial dissection as it was not performed until December, 1702. The anatomizing took eight days; the body was divided into as many regions and each demonstration was done by a different professor.

In 1705, Robert Eliot was chosen as public dissector and paid by the town; he was, therefore, the first Professor of Anatomy at the University of Edinburgh and in Great Britain. His salary was 15 pounds per annum and he held the position for twelve years. In 1720, following the temporary tenures of John M'Gill and Adam Drummond, the chair was given to the first of the three Monros, who collectively were to form an unparalleled professorial hierarchy lasting for 12 decades (Ball, '28; Comrie, '22; Creswell, '14; Cunningham, '03; Lonsdale, 1870; Watson, '36).

Body snatching got an early start in Scotland and it came to the attention of the College of Surgeons in Edinburgh in 1711. This organization took official notice of the situation and wrote a protest stating that "of late there has been a violation of sepulchres in the Grey-Friars Churchyard by some who most unchristianly have been stealing the bodies of the dead out of their graves" (Creswell, '14; Lonsdale, 1870; Watson, '36). Apparently, no attention was paid to this notice; in fact, the practice increased, if anything.

The reign of the Alexander Monros at the Department of Anatomy at the University of Edinburgh, began in 1720 and 
lasted for a duration of 126 years. During this time, students flocked to that city from all over the world. As many as 400 resided there during one session for the purpose of studying anatomy at the University. However, Monro the first, began with fiftyseven pupils and did his teaching in the anatomical theatre, or Surgeon's Hall, as it was called, which belonged to the Royal College of Surgeons.

Due to public concern over the status of the resurrectionists, the Royal College of Surgeons made the regulation, in 1721, that all anatomical students be required to sign an agreement or indenture promising not to participate in grave robbing. They offered to pay 5 pounds to anyone proving a pupil guilty of such a misdemeanor. This ruling was ineffective for the students considered it a point of honor to see that their own teacher had enough cadavers; a spirited rivalry, not always friendly, developed between the groups from different schools. For example, the pupils of one lecturer, on hearing that another band was planning on raising a body on a particular night, secreted themselves among the gravestones until after the body had been removed and the grave refilled with soil. Then they suddenly appeared, wearing ghostly white sheets and emitting wild shrieks to the confusion of the opposition, who fled leaving the territory to the invaders.

Monro I changed his pedagogic quarters to a place within the confines of the University walls, in the year of 1725, in response to mob violence of some proportion, directed against Surgeon's Hall. The edifice stood in peril of being completely demolished following the discovery of a body snatching incident by certain members of the populace. They destroyed the windows and threatened the life of the eminent professor as well as his assistants and students (Ball, '28; Creswell, '14; Lonsdale, 1870; Watson, '36). This anatomist made some innovations in teaching anatomy: he extended the course so it continued from October to May and included some history of anatomy, osteology, pathology, physiology and comparative anatomy.

It was customary in Edinburgh at that time to advertise the anatomizing of a human subject in one of the daily newspapers. The following is one which was written in the Daily Advertiser of January 15, 1742: "Notice is hereby given that 
there being a publick Body at Barbers and Surgeons Hall, the Demonstrations of Anatomy and the Operations of Surgery will be at the Hall this evening and tomorrow at six o'clock precisely, in the Amphitheatre" (Guttmacher, '35). This indicates that the dissections were open to the public, that they were held in the evening, and lasted only two days.

It was during the tenure of Monro I that two nurses, Helen Torrence and Jean Waldie, residents of Edinburgh, committed the first known murder in Great Britain in which the body was sold for anatomical use. The time was 1752. It started with a promise by them to supply some doctor's apprentices with a subject. Their original plan revolved around the deathwatch of a child. After he succumbed, and the opportunity presented itself, they expected to substitute something for the body in the coffin. They were thwarted in this attempt because the parents refused to hire them for the job. They then decided to victimize another boy, the son of John Dallas, a prominent man of Edinburgh. When the eight-year-old lad was alone in his home, they seized him, enticed him to their own premises and smothered him. It is said that he was carried to the room of one of the surgeons, in the apron of Helen Torrence, quite a feat for a woman. She was offered 2 shillings but bargained for another 10 pence, which she received, and used to buy a drachm. Because of the crudeness of execution, the facts in the case soon came to light and both were hanged for their inhuman crime (Burr, '17; Haggard, '29; Guttmacher, '35).

Alexander Monro II has been judged to have been an even more brilliant teacher and investigator than his illustrious father. He succeeded to the chair in 1758 and held it until 1798. For six decades, the University held a virtual monopoly of students during which no opposition prevailed against the teaching of the first two Monros. However, no less a personage than John Bell, in 1786, publicized the fact that neither of the pair was an operating surgeon and held that it was a weak spot in their instruction.

John Bell began lecturing in 1786; he was so successful that by 1790 he built a private anatomical school which had a large enrollment. He is regarded as the founder of surgical anatomy. It took thirteen years before a bitter faction at the University 
of Edinburgh organized against him; through its influence he was dismissed from the hospital. His brother, Charles, took over

- the class in 1799, but opposition continued against the school and it was never able to attract more than ninety students under his direction. Therefore, he left for London in 1804 (Brash, '30; Comrie, '22).

Alexander Monro III proved to be an unsuccessful teacher and students began to get instruction at the private anatomical rooms which were springing up throughout the city. The opening of these institutions paved the way for a greater number of medical students; the enrollment increased from 200 in 1793 to over 1,000 in 1820. By 1828, eight private schools had been established there (Comrie, '22).

One of the worthwhile innovations in the teaching of anatomy in the British Isles was allowing medical students to make their own dissections. Up to the year of 1800 , they were not given this privilege; only a few favored and enthusiastic ones had helped their teachers prepare the demonstrations, but universal anatomizing wasn't practiced because of lack of material. Dissections by students became compulsory in 1826, both in the College of Surgeons and at the University of Edinburgh. In 1831, the chair of surgery was separated from anatomy and this marked the beginning of the modern epoch in anatomical teaching in the city (Comrie, '22).

The introduction of student dissection set one of the worlds most infamous trades into full motion. Bodies became so scarce that professors and practitioners, as well as professional resurrectionists and murderers plied the field. Although the medical men wanted the subjects for scientific purposes such as increasing basic anatomical knowledge, perfecting or following up the results of surgical operations and studying the effects of disease processes, the latter were interested in monetary gains only. The following stories illustrate the means these men used to attain their own particular end, in Scotland.

In the early days of the practice of Robert Liston (17941847), who was the first man in England to perform a major operation under ether anesthesia, he sought to obtain the body of a man buried in Fifeshire, who had passed away as a result of 
a peculiar ailment. This was before he moved to London. Taking two students with him, he rowed across the river Forth at Queensferry, to the village of Rosyth. On reaching the desired spot, they were successful in raising the subject, which they put in a sack; feeling tired from their exertions, they put the bundle behind a hedge and sauntered to a neighboring inn to partake of some refreshments.

To the astonishment of the trio, a drunken sailor staggered into the tavern, with their bag on his shoulder. The man was babbling that he undoubtedly had discovered a valuable treasure, since he saw three men dig it up and hide it. When they saw the discoverer open the sack, Liston and his aides prepared themselves for a hasty retreat, but everyone else was ahead of them, rushing through the door in dire panic. Taking their time, the amateur resurrectionists reclosed the sack, transported it to their anchored boat and proceeded leisurely back to Edinburgh (Watson, '36).

Sometimes it took a great deal of strategy in order for body snatchers to acquire the material they knew, by previous experience, would provide a large fee. Such was the case of a country lad, with hydrocephalic disease, who had developed an enormously large head. The case had attracted the attention of many physicians who thought in terms of collecting a rare osteological specimen. After the boy's early death, which was inevitable, the body was buried in a cemetery located on the shore of the Firth of Forth, not far from Edinburgh. His grave was guarded nightly by paid, trustworthy watchers who were cognizant of the prize underneath their feet. It was not considered necessary to take precautions in daylight. Special agents of Dr. Liston were unable to obtain the specimen by means of bribery, which was usually successful. Many weeks passed and the resurrectionists retired from the scene, apparently leaving the watchers as the victors in the contest. Later, one evening, at dusk two smartly dressed men, looking like gentlemen, smoking cigars, drove up to the chief lodginghouse of the village and informed the stableboy that they expected a package to be delivered and deposited in the box part of their cart. They then disappeared. Not long after, a third person in the drama, dressed in impeccable livery, ap- 
peared and deposited a parcel under the seat and walked off. The original pair returned presently, ordered their trap and briskly drove off. When darkness descended, the guards, on returning to their job, noticed that the grave had been tampered with, the coffin removed and the body taken. This was accomplished by the trio within an interval of thirty minutes, an assignment which had baffled experienced resurrectionists for weeks. The skeleton was bequeathed to one of England's great anatomical museums by Dr. Liston, and was given the number, 3489 (Guttmacher, '35). This figure gives an indication of the quantity of specimens collected by the middle of the 19th Century. Liston, a distinguished Edinburgh surgeon, in this incident, joined forces with one of the most nefarious London gangs of resurrectionists, led by a man named Ben Crouch. It demonstrates how a certain kind of strategy and foresight succeeded, where bribery and possibly brute force failed.

An interesting picture is painted of a well-known Edinburgh body snatcher of the early 19th Century period, one Andrew Lees, or Merry-Lees, as he was called. He was exceedingly tall, slender, rawboned, with an elongated, wan face which was likely to excite laughter at first sight. His physiognomy, however, was extremely flexible and he could control his muscles to suit any emotional need: tragedy, comedy or farce. His face was dismal and pale when assuming the role of a mourner; it became timid and countrified when approaching a house of death, inquiring after a deceased; on entering such a place, his eyes became bleared and overflowing with tears. He wore clothes to suit the occasion; sometimes, they were shabby, of the cast-off type, which fit him very loosely and hung upon his sharp joints so that they actually flapped with the wind.

As a grave robber, he was always on the alert for candidates in their last illness, who were friendless. He would canvass a wide territory searching for such people, and when spotted, would learn as much of their family background as possible. Eventually, entrance after death, might be gained under the guise of a distant relative. From this point on, it required clever acting, subterfuge and persuasion to gain his goal. His efforts in this direction were 
attended with a large measure of success. He is on record as having sold the body of his exhumed sister (Guttmacher, '35).

It was difficult, if not impossible, to carry out resurrectionist projects alone because the human body could not be handled singly whether unburied or buried. Three assistants worked with Merry-Lees and were named Spune, Mowatt and Howard. The first was a little man who acted demure, resigned and saintly. All of his assigned duties were carried out in a grave and stately manner. To Howard, was given the task of impersonating a clergyman, when such was needed. This entailed wearing an appropriate black suit with a white cravat, knowing how to recite prayers and importune those around the coffin to reflect on the uncertainties of life and the need for spiritual uplift. Mowatt was a general handyman. When their coup went off successfully, they served as mourners for the funeral cortege, which usually proceeded toward the suburbs. When night came, no time was lost in conveying the body to a selected dissecting-room, where an agreed amount of cash was put in Lees' hand. The climax to the series of events usually resulted in a wild night of drinking and revelry, with the head of the gang leading the way. Lees was known to average about sixteen large glasses of whisky per day and, on occasion, he could consume as many pints.

A remarkable series of events, murder-wise occurred in the year of 1828, in Edinburgh. The principal characters in this drama were two-men and two women: Mrs. Hare, William Hare, William Burke and his mistress, Helen McDougal. The women always acted as accomplices up to the point where the crime was committed, when both discreetly withdrew. Their business of selling bodies to the anatomical schools began as follows: an old pensioner, by name of Donald, a roomer in the lodginghouse of Hare, died leaving an unpaid debt of 4 pounds, on November 29, 1827. The orwner decided that the only way he could retrieve the money due him was to sell the body to the anatomists. He enlisted the aid of Burke and they were successful in substituting tanner's bark in the coffin, which had been sent to the house by the parish authorities. The body was hidden in the bed. It was sold later to the laboratory of Dr. Robert Knox for the sum of 
7 - pounds 10 shillings which meant that a handsome profit was made on the deal. They spent it on a drunken carousal.

Finding it tedious waiting for another such case, they decided to prowl the streets in search of a suitable victim. They met one,

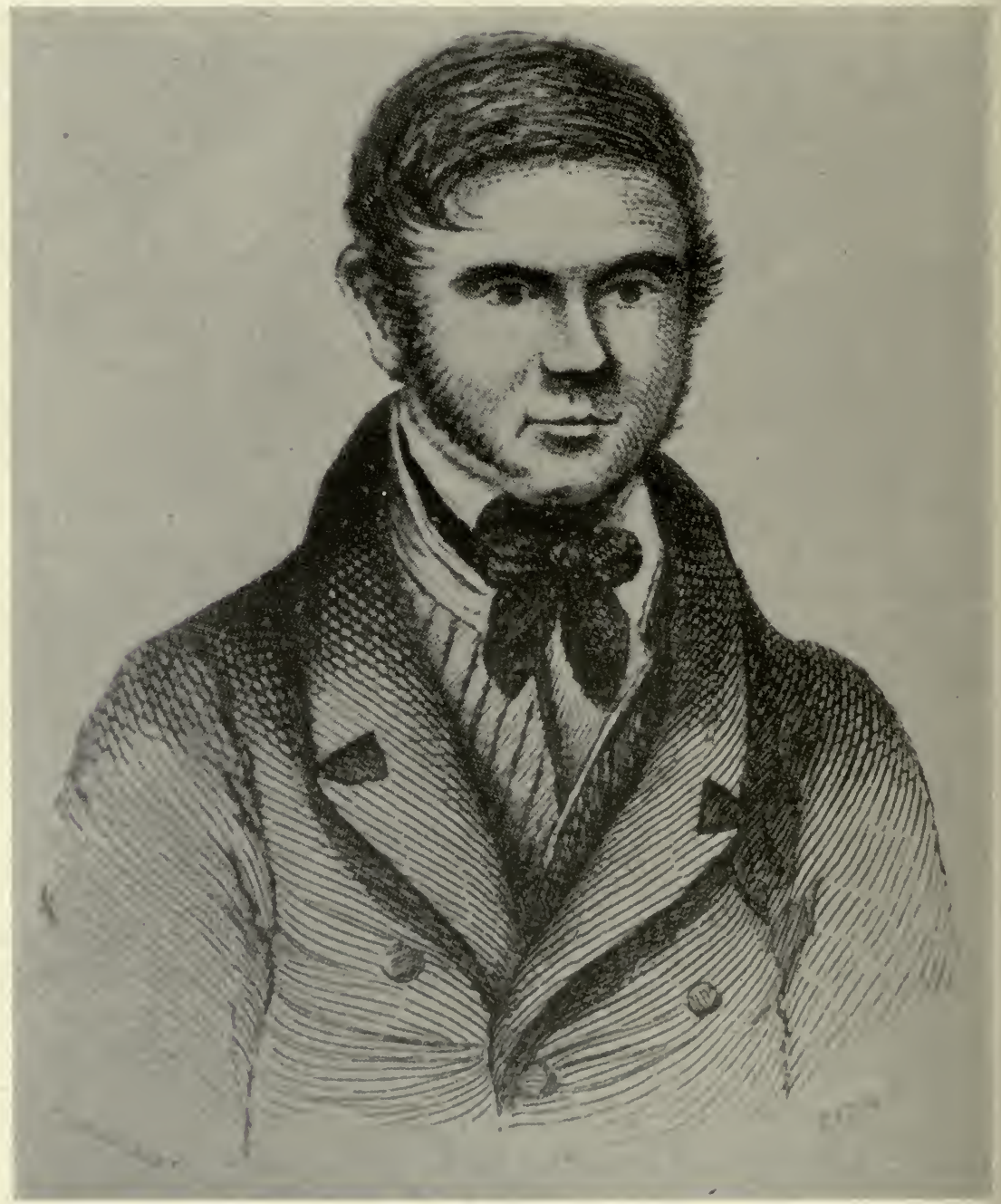

Figure 12. William Burke as he appeared at the Bar. Drawn by Lutenor and engraved by T. Clerk. Edinburgh, 1829. From Ball, J. M.: The Sack'em-up Men. London, Oliver \& Boyd, 1928. By permission of Oliver \& Boyd. 


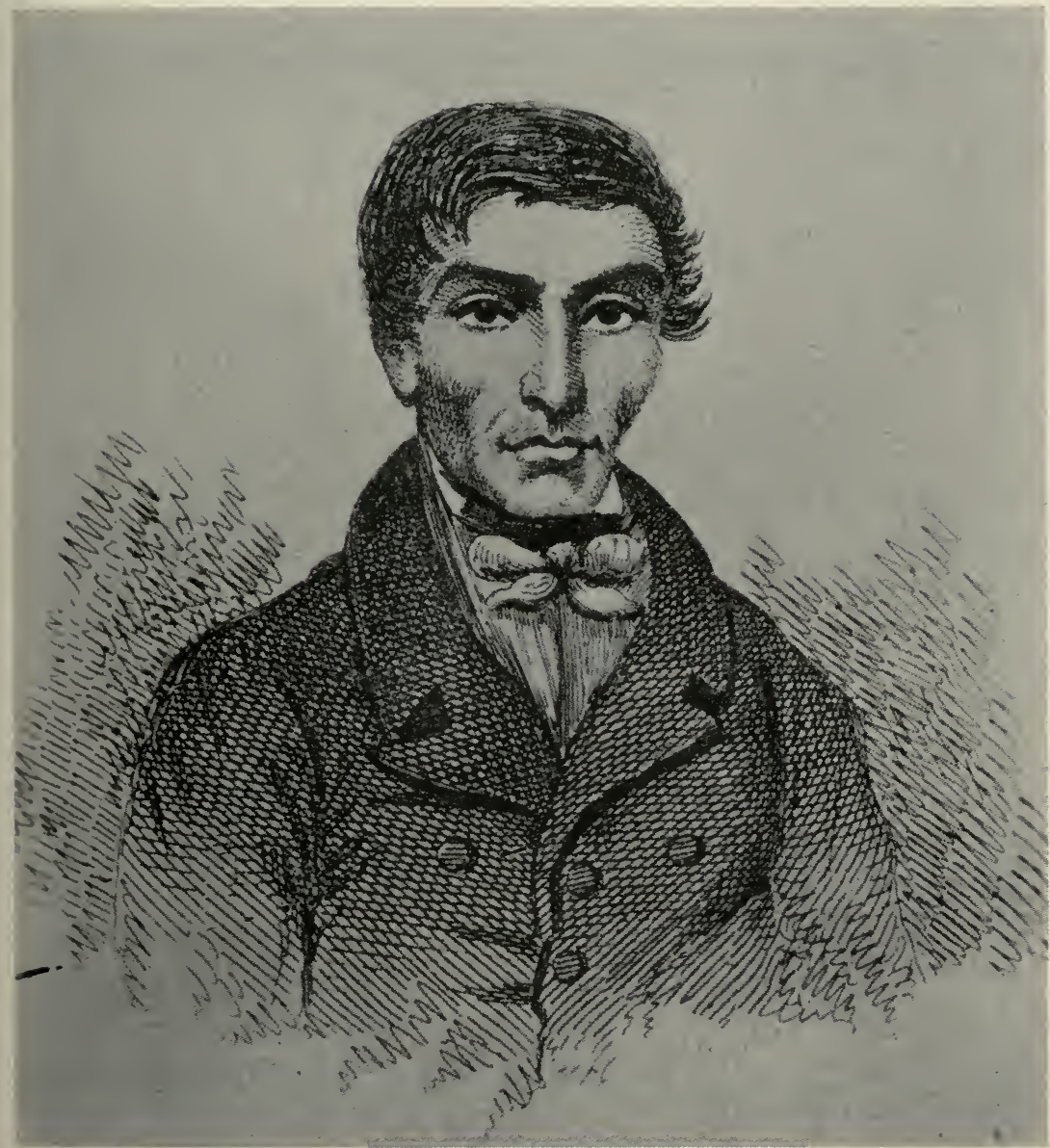

Figure 13. William Hare as he appeared at the Bar. Drawn by Lutenor and engraved by Clerk. Edinburgh, 1829. From Ball, J. M.: The Sack'em-up Men. London, Oliver \& Boyd, 1928. By permission of Oliver \& Boyd.

on February 12, 1828, in the person of an old woman, Abigail Simpson, who was in the city from the neighboring village of Gilmerton. She was under the influence of liquor and readily followed them to Hare's lodginghouse, at their invitation. Plied with more strong drink, she became very merry, talkative, and entered into the spirit of the occasion by singing her favorite, simple songs. Eventually, she drank herself into a semicomatose 
condition. When this state was reached, Hare placed his hands over her mouth and nose to stop respiration, while Burke sprawled over her body to prevent struggling. The woman was dead within a few minutes. This body brought 10 pounds from Dr. Robert Knox. This was a modification of the method used by the nurses, Helen Torrence and Jean Waldie, in 1752, and was characterized by leaving no marks of violence on the victim.

The body of Abigail Simpson was disposed of as follows: students of Dr. Knox, present in his dissecting-room, were informed that another subject was available for the anatomist. They, in turn, relayed this news to the professor who arranged to send a porter to meet Burke and Hare behind the Edinburgh castle, which still stands well-preserved, at a specified hour during the night. The body was carried to this spot in a chest by Burke and Hare and from there it was conveyed to the dissecting-room where Dr. Knox met them to examine the body, which was by then cold and stiff. He said he liked its freshness but made no interrogations as to how it was obtained.

Between February 12th and November 1st, 1828, an interval of eight and one-half months, a total of fifteen additional murders were committed by this pair and all reached the door of the anatomical laboratory of Knox. This gives an indication of the whetted appetites and vampirian thirst, of the assassins. The age or sex of the victims did not matter in their standards. They were made up of widows, orphans, streetwalkers and imbeciles. Only a few more special incidents are described below, because each murder was a replica of the first.

One which attracted attention but was not suspected, was that of a young prostitute by name of Mary Patterson, who inhabited the streets of Edinburgh. She was treated by Burke and Hare in the usual manner: enticed to the lodginghouse, plied with drink and then smothered. Four hours later, she was lying in the dissecting-room, her body having been sold to Knox. Although the corpse was already cold, rigor mortis had not yet set in. The murderers were paid 8 pounds. At the time, the girl's hair was in curlpapers; there were no disfigurements, and her external appearance suggested that she had not been buried. Two of the students in the lab at the time thought they knew 
who she was. When Burke and Hare were asked where the body was obtained, the reply was that it had been purchased from an old woman living near Canongate. During life, Mary Patterson had been an extremely good looking girl, with well-shaped limbs and figure. Knox was impressed with these features, so much so, that he preserved the body for three months in alcohol and invited an artist to sketch it. Robert Louis Stevenson, in his tale, The Body Snatchers, used her as an important character.

Another case was that of James Wilson, better known as "Daft Jamie," who was a wandering imbecile. In spite of this psychological condition, he was well-known and a favorite with all, including medical students, because of his kind and generous heart. There was no belligerence in his make-up and he had never been known to defend himself, in spite of his nineteen years of age. This was taken advantage of by boys half his age and size. One of the common sights of the city was to see him in full flight before a group of youngsters. He knew some facts that no other was cognizant of, such as the number of lamps in the city. This must have taken some detective work on his part. He was also clever with little conundrums. "In what month of the year do the ladies talk the least?" His answer was, "The month of February because there wiz least days in it!" Another of his questions was, "Why is a jailer like a musician?" His reply, "Because he must take care of his key." Deserting his mother at the age of nine, he had eked out a living as best he could, being dependent upon the mercy and pity of the town's people. Liquor was something that he liked, but there was rarely enough money in his pockets to satisfy his thirst (Guttmacher, '35).

Mrs. Hare entered the picture in this drama. She accosted Daft Jamie on the street and was successful in getting him to follow her to the boardinghouse, as it wasn't his nature to be suspicious of adults; in general, he had found them sympathetic. She offered him a drink, which was first refused but later accepted, along with many others, until he was partly inebriated. Burke and Hare, who had been summoned, found that he put up a terrific struggle, both because he was naturally strong and not entirely intoxicated; he was finally smothered and his body delivered to the dissection-room of Dr. Knox. Again, no questions were asked 
by the recipients of the subject although it may have been recognized. The absence of Daft Jamie was quickly noted and his mysterious disappearance took a remarkable hold on the mind of the populace, not only in Edinburgh but throughout the entire country, and it remained so until the reason was solved.

The final murder committed by Burke and Hare was that of a woman named Mary Docherty, who had traveled to Edinburgh in search of her lost son. Burke contacted her in the vicinity of a grocery store, located near his home and started a conversation. On learning her name, he informed her that his mother was also a Docherty and intimated that they were of the same clan. By this means, he obtained her good will, which was aided by a few glasses of whisky at a neighboring pub. She accompanied him home. A hilarious party followed with Hare and his wife, Burke and his mistress and a couple named Gray being present. She was "burked" in the usual way the ensuing morning. Her naked body was then put under the bed, and partially covered with straw, until a tea crate could be found.

The next morning Mr. Gray inquired for the old lady and was given an evasive answer by Mrs. Hare. During the breakfast meal, which was served in the room with the corpse. Burke behaved peculiarly. With a bottle of whisky in his hand, he threw some of its contents under the bed, on top of it and up to the ceiling of the apartment; on occasion, he put drops of it on his breast opening his shirt for this purpose, and then he would take some sips. When Mrs. Gray wanted to search for some potatoes, which were under the bedstead, she was forbidden to do so by Burke; instead he reached for and obtained the bag. This combination of events made Mrs. Gray suspicious; when the others left the room momentarily, she bent down and lifted the straw and in so doing, caught hold of the arm of the dead woman. She motioned silently to her husband, who had also remained; they investigated further and were able to identify the subject as being that of the elderly woman they had met the night before. They departed immediately and informed the police of their discovery; the four persons, Burke, Helen McDougal, Mr. and Mrs. Hare, were apprehended, imprisoned and indicted. The news of their capture spread like wildfire and set off one of the greatest 
publicity movements in the history of Great Britain: via newspapers, magazines and books (Guttmacher, '35).

An important figure, in the murders, always standing mysteriously in the background, was Dr. Robert Knox. Most of the following is taken from Lonsdale's (1870) biography of him. He is described as the greatest anatomist of his time; he was a lineal descendant of the famous John Knox, the Reformer, the promising son of a farmer, who was sent to Edinburgh to obtain the best education offered in the country. After serving five years as a military surgeon, he was offered a co-partnership with Dr. John Barclay, owner of the most respected anatomical establishment in Edinburgh, who was nearing the end of his allotted years. This was in March, 1825. Knox came into possession of the class and whatever profits he could accumulate from it, after just eighteen months service, as Barclay died on August 24, 1826.

Knox immediately showed that as a lecturer, he was a man of marked individuality in style, that he treated anatomy as a pastime of the hour, emphasizing the practical as well as the philosophical side of the subject. He soon was to be called "the incomparable Knox," by many of his students. There is a place for drama and attire in the teaching profession and Knox could be classified as unusual on both counts. He was, on the basis of physique alone, bound to attract attention and stimulate interest.

In height, he was slightly above middle stature, very muscular and possessive of a nervo-sanguineous temperament. He was more like a Frenchman than Scot in disposition. In build, he looked something like a wrestler, having a wide chest, powerful shoulders and long arms. This appearance, however, was neutralized both by his gentlemanly manners and intellectuality. His military experience may have accounted for the fact that his carriage was upright, his walk firm and his movements free and lithesome. Besides having a large nose, full mouth, strong lines, coarse features, caused by a severe attack of smallpox, and a bald head, he possessed an atrophied left eye. The muscles of his face seemed to be stimulated most when his brain was at work although unpleasant involuntary twitchings occurred otherwise.

It was in the sphere of personality that Knox stood out, where his courtesy and conversation atoned for his physical defects. 
In manner, he was suave and full of pleasantry; his voice was gentle and well-modulated and his ready, persuasive tongue captured all the members of his audience who could appreciate excellent speech.

Lecturing was performed by Knox in full dress. At such times, he wore a black coat, a showy vest embroidered with rich purple, a high, white cravat, the folds of which passed through a diamond ring, a conspicuous shirt collar, delicately folded linen over the front of his shirt, watch-seals and pendants. Across his chest, dangled an ornate, gold chain. All this was set off by dark trousers and shining boots. His entire regalia provided a sharp contrast to the osseous forms and decaying specimens around him.

As far as the majority of students were concerned, Knox had no real competitors as a teacher in the Edinburgh medical schools. It was recognized that his style, his appearance, the illustrations he used and his extraordinary powers of speech added up to a fascinating presentation of the subject of anatomy and that he invested it with the loftiest aims.

Over a nine-year period, from 1826 to 1835, his classes averaged 335 students, and during the session of 1828-1829 he had 504. They were the largest ever assembled in Britain. Since his lecture room held a maximum of 200 pupils, he was obliged to give the same address three times a day. So interested, however, was Knox with his duties that it fatigued him not at all. He sought popularity and it came to him in abundance. It was known that he practiced his lectures beforehand. The bulk of his students were medical but intermixed with these were barristers, scholars, mathematicians, advocates and clergymen. On occasion, there were also noblemen, artists and men of letters in attendance. His students became known as "Knoxites," men of intelligence, who were naturally attracted to such a man of talent; many became outstanding in the medical field and held important posts in the various medical societies then extant.

This is a brief description of the man who became involved in the murders of Burke and Hare and whose name mingled intimately with theirs after their deeds became known. His character was defamed on every hand by all means of communication. An infuriated mob, made up of the lowest rabble of the town, who, 
fully expected to capture and hang him, along with his effigy, attacked his home. Outside of this group, the press, with few exceptions censured him. His rivals, in the other anatomical schools were mostly pleased at the turn of events, which they felt would develop to their benefit; they contributed to damaging his repu-

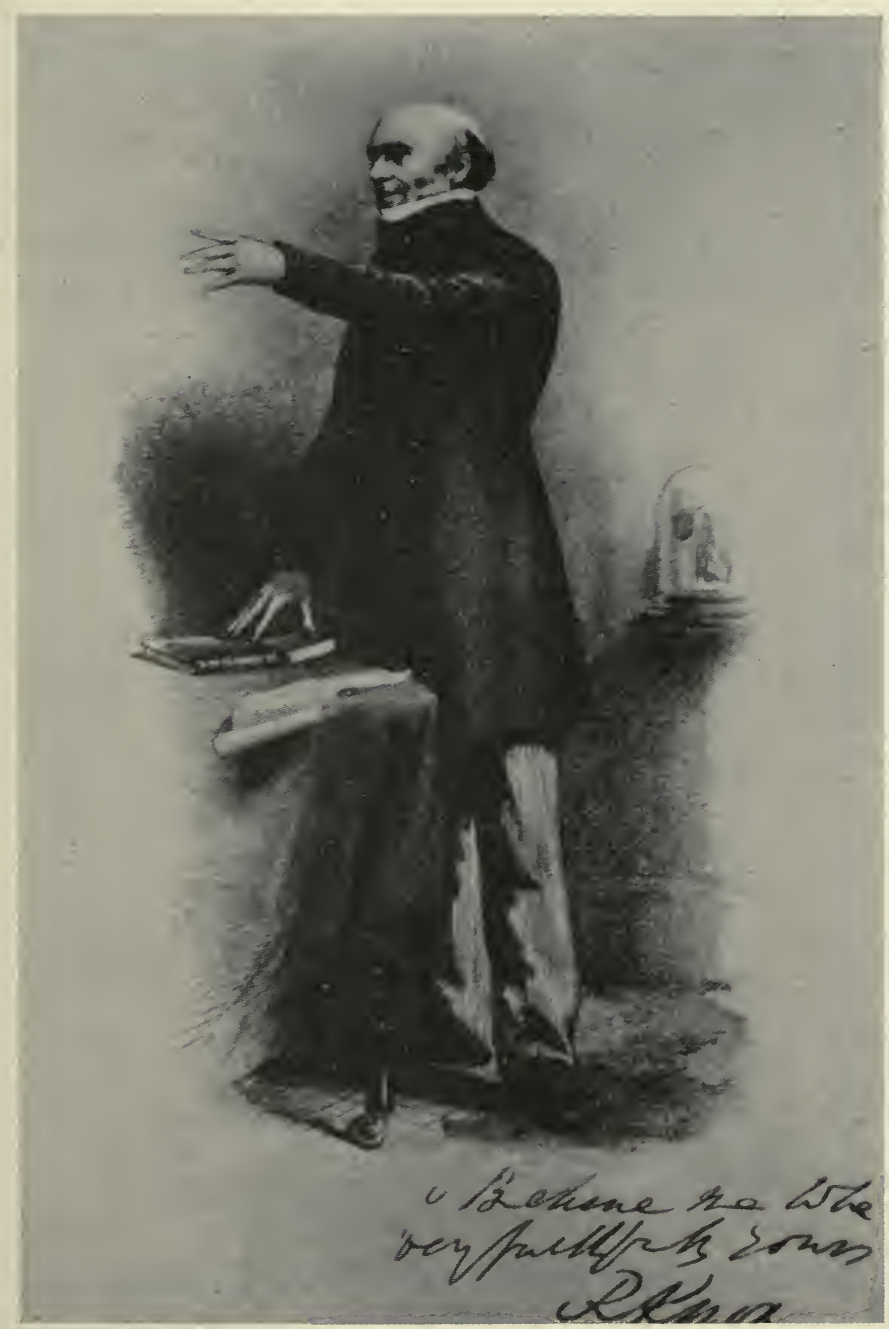

Figure 14. Robert Knox (1791-1862) From Ball, J. M.: The Sack-'em-up Men. London, Oliver \& Boyd, 1928. By permission of Oliver \& Boyd. 
tation. There were those who also became interested in probing his religious beliefs and wondered what was to become of his soul. When it was discovered that Knox belonged to no sect or congregation, all the denominations of churches breathed more freely. This gave them an opportunity to condemn him as a miserable sinner.

The policy followed by Knox was to say nothing; he allowed the whole winter to pass without making any public declaration which might appease the clamor. He made an error in expecting a subsidence of the aroused emotions. In March, 1829, his character was blasted, in a foul manner, in an article, written in Blackwood's Magazine, by John Wilson, Professor of Moral Philosophy. This author even attacked the students of Knox for displaying an obvious, affectionate regard for their teacher. The medical profession did not show any great signs of supporting him; little sympathy was extended to him from that direction. Lonsdale (1870) defended him on every count stating that Knox never went out on body snatching expeditions, that he abhorred resurrectionists and that he had suggested that the schools of London, Dublin and Edinburgh take joint action in seeking aid from the Parliament on anatomical affairs. Further, it was by the merest accident that Burke had come in contact with him; it might have been any other teacher, especially Alexander Monro III, Professor of Anatomy at the University of Edinburgh.

The anatomical contemporaries of Knox showed overt uncharitableness and even open hostility towards him, the teacher who had attracted about two-thirds of all the medical students, in Edinburgh, to his class. It seems possible that most of the attacks made on him by professionals originated from disappointed rivals. His laboratory had always been amply supplied with cadavers principally because he was willing to pay good prices for them; he disliked seeing his class disappointed. The greatest amount paid was 25 guineas. He was known to be lavish and careless of his own pocketbook, having spent the incredible amount of about 800 pounds for subjects during one session. He hated to see a single empty table even though there were sometimes 400 pupils around him. Special agents were sent as 
far as Dublin to make cadaver arrangements for the approaching session in October, 1828.

When the case of Burke and Hare was reviewed, the fact was revealed that Knox saw these two individuals on just two occasions during the delivery of the sixteen murdered bodies; the others were received either by his student assistants, who were just out of their teens, the janitor of his establishment or the porter. In no case, did they find any suspicious marks upon them. Since all cadavers were obtained surreptitiously by thieves and lawless villains, there was little general questioning done; it was regarded as folly and impolite to pry into the matter too much, according to Lonsdale. Newly dead corpses, obtained from other sources than the grave, were not uncommon in the practical rooms. The resurrectionists were always on the search for persons dying without friends. On their side, too, was the fact that no inquests by coroners were held in Scotland which precluded an authoritative investigation of questionable cases.

Not all influential men of medicine in those hectic days, came to the defense and rescue of Knox and other members of the anatomical profession, as did Lonsdale (1870). Sir Thomas Wakley, in his capacity as editor of Lancet, wrote what can be called diatribes against him and the contemporary teachers of anatomy. He charged them all with being in commerce, that they were a cold-blooded lot, showing a monstrous indifference and apathy to the manner in which they obtained bodies; that they kept their shambles open to resurrectionists and possibly murderers; that they enjoyed a profitable monopoly, regulating their student fees to the exorbitant demand of the dealers in bodies. The schools of anatomy, as they were then run, he believed, constituted a public nuisance, that dissection must either be completely suppressed or encouraged, that the practice might be overrated in its importance and that its chief claim to a place in the medical curriculum was related to the operations performed by surgeons. He charged that one teacher of anatomy took a burial ground for himself and conducted a business from a small house adjoining his plot. He made a profit in two ways: by charging handsomely for entering bodies, then, later exhuming them and demanding as much as 8 to 12 guineas from his pupils. This practice led, in some schools, 
to dissection of three times as many subjects as were required for the purposes of science. Wakley advocated that unclaimed bodies be appropriated and made available for anatomical dissection, and that executed criminals be divorced from it, because this tradition had superadded to the popular, natural aversion to dissection by placing a definite stigma upon it.

In respect to the fate of Burke and Hare, and their two female partners, justice moved speedily. The court, since it had nothing more than circumstantial evidence against them, offered immunity to the least guilty of the pair, namely Hare, providing he turned state's evidence. This, he did. It was Burke alone who was found guilty; both women were freed.

The Lord Chief Justice in the notorious case passed sentence as follows: "In regard to your case, the only doubt that has crossed my mind is whether your body should not be exhibited in chains, in order to deter others from like crimes in the future. But taking into consideration that the public eye would be offended with so dismal an exhibition, I am disposed to agree that your sentence shall be execution in the usual way, but accompanied with the statement of the punishment of the crime of murder . . . that your body shall be publicly dissected and anatomized. And I trust that, if it is ever customary to preserve skeletons, yours shall be preserved in order that posterity may keep in remembrance your atrocious crimes" (Guttmacher, '35).

Before his death, Burke made a full written confession which completely exonerated Dr. Robert Knox.

The hanging of Burke attracted nationwide attention and was witnessed by about 25,000 people. As the trap was sprung, a fearful yell was sent up by the excited multitude. After death was pronounced, the body was removed to the anatomical rooms of Dr. Monro III, Professor of Anatomy, at the University of Edinburgh. The same afternoon, he gave a lecture on it, after first removing the head of the executed man. This part of the ceremony was so popular that admittance was regulated by ticket for students of the teacher's regular class. After the reserved seats were occupied, those from other medical schools flocked in until the amphitheatre was filled. A large number of people assembled outside, clamoring for admission. To pacify and prevent them from 
tearing down the building, they were informed that the body of Burke would be put on public exhibition. On the following day, it was placed naked on a black, marble table in the anatomic theatre. A crowd streamed through the doors from 10 A.M. until darkness descended on the scene. It was estimated that sixty persons per minute filed through the narrow passage in front of his remains, totaling up to about 25,000.

Obeying the wishes of the Lord Chief Justice, his osseous parts were cleaned and articulated; his skeleton can be viewed today in the anatomical museum at Edinburgh.

The other three culprits, associated with the murder, although freed, did not fare very well after the trial. In order to evade possible mob action, they were liberated from prison in great secrecy. Helen McDougal emigrated to Australia and died incognito there. Working on a job as a plasterer's apprentice, Hare's identity was discovered; he was seized and was either thrown into a bed of lime or some of this substance was cast over him. Whichever happened, he lost his eyesight. He is known to have lived for many years afterward. Mrs. Hare, apparently, deserted her husband, and disappeared from public view.

For a long period afterwards, a reign of terror, inflamed by the publicity, existed among all classes throughout Scotland and England. The poor countryfolk were unable to afford regular newspapers since they sold for half a shilling; the sale of these was limited to the towns. For news, such people had to resort largely to the pungent write-ups in the broadsides published on a large sheet of paper. Ordinarily it was printed on one side. The wandering hawkers filled their baskets with these and sold them to individuals living in hamlets and on farms. Many coarse ballads, centering around the murders were also sung. Collectively, these stirred the minds of the people in an exaggerated manner so that it was rare to find a man or woman out after sunset.

Numerous books headlined the events revolving around the Burke and Hare episodes; some of these were the following.

Charles Dickens' A Tale of Two Cities.

Thomas Hood's Mary's Ghost, a pathetic ballad, on the humorous side. 
Alexander Leighton's (alias Nimmo of Edinburgh) The Court of Cacus, or The Story of Burke and Hare.

Edward B. Lytton's Lucretia, The Children of Night.

David M. Moir's The Life of Mansie Wauch, Tailor in Dalkeith.

Robert L. Stevenson's The Body Snatcher.

John Wilson's article in Blackwood's Magazine.

Sam Warren's Diary of a Late Physician, a chapter entitled, "Grave Doings" (Ball, '28).

Lord Cockburn, in a charming book on Scottish manners, Memorial of His Time, included passages regarding the status of the anatomists of his period. He is quoted as follows: "All of our anatomists incurred a most unjust and very alarming, though not an unnatural odium: Dr. Knox in particular, against whom not only the anger of the populace, but the condemnation of more intelligent persons, was specially directed. But tried in reference to the invariable and the necessary practice of the profession, our anatomists were spotlessly correct, and Knox the most correct of them all" (Lonsdale, 1870). This author was regarded as one of the ablest representatives of the Scottish Bar, as one who could sift evidence and see through human motives with the readiness of instinct.

A series of lithographic prints, by Alexander Leighton, alias Nimmo, one of whose books, is mentioned above, merits special mention. They were entitled, Wretche's Illustration of Shakespeare, but some dubbed them, Nimmo's Illustrations of Wretches, and were directed mainly toward Knox. In one of the caricatures, the devil is portrayed standing in a garden with a large pair of shears, ready to crop a "NOX-I-OUS plant." It was intended to show "an old virtuoso appropriating a new curiosity." This drawing and others were meant to damage Knox in the minds of the masses, both as a citizen and lecturer (Lonsdale, 1870).

The romantic book by Alexander Leighton (Nimmo), Court of Cacus, or The Story of Burke and Hare, lacked historical truth and was a dressed-up tale which highlighted moral and pious reflections to satisfy the Scottish mind. The author's prejudices prevailed on every page and many readers mistook his views as a true criterion of the events which happened. 
The article by John Wilson (alias Christopher North), Professor of Moral Philosophy, in Blackwood's Magazine, published in March of 1829, made every effort to defame the character of Robert Knox. Quoting Lonsdale (1870): “Literary ruffianism is too mild a term to apply to the foul words used by Wilson, who, not content with holding up Knox to public execration, rushed with the savagery of the warhoop and tomahawk upon an unoffending anatomical class for showing an affectionate regard for their great teacher."

Some of Knox's friends took matters into their own hands and selected an agent, a Mr. Ellis, to make a rigid and unsparing examination into the facts. This gentleman appeared before the Dean of Faculty, at the University of Edinburgh, and other counsel. He gave it as his belief that no grounds existed for action and that Dr. Knox should resist the temptation of carrying his case to court. The latter was to be avoided because the disclosure of even the most innocent proceedings in a dissecting-room would be a shock to the public and harmful to anatomical science. The faculty decided to recommend that a few distinguished persons, whose opinions carried undoubted weight, be asked to investigate the matter. This led to the appointment of a special committee, consisting of nine members, chaired by Dr. Robinson, Secretary of the Royal Society of Surgery.

This committee made an extensive examination of the evidence from every quarter. Their report stated that there was no indication that either Dr. Knox, or his assistants, knew that murder was committed when the subjects reached his laboratory. It intimated that there was, however, circumstantial evidence which should have excited suspicion of foul play, that is, the freshness and unmarked condition of the bodies. They were convinced that neither Knox, his assistants or students, harbored any doubts, nor did they attempt to disfigure the features which might have prevented detection. Further, they expressed the opinion that Knox, and particularly his aides, might have been more cautious in their dealings with Burke and Hare, that too ready an ear was given to the plausible stories of the murderers. The 1,140 word report concluded with the statement that Knox could be blamed for laxity of regulation under which the cadavers were received 
into his rooms; because of his standards, he unintentionally gave a degree of facility to the disposal of the victims of Burke and Hare. However, in the final analysis, he was not acting contrary to the law of the land.

A few days after this report, March 17, 1829, Knox broke his long silence by writing a letter to the editor of the Caledonian Mercury, an Edinburgh newspaper, feeling that he owed an explanation to his friends and the medical profession. Parts of it are hereby paraphrased. He explained that by the nature of his work he ran the risk of being imposed upon by those who furnished anatomical material. Every pedagogue in anatomy, he felt, occasionally incurred odium from his supposed violations of the law, without which anatomy could scarcely be practiced. In view of the events, he had expected to become an object of popular prejudice but he thought that extra means had been taken to inflame the public mind, without which the bias would have ultimately passed away. In his mind, he had been exposed to a misfortune which could have happened to anyone else in his situation.

Knox went on to say that every effort had been employed to convert his mischance into one of positive and intentional personal guilt of the most dreadful character. Scarcely any individual had ever been the object of more systematic or atrocious attacks than he, and he knew from what quarter they emanated. The public authorities had never charged him with any crime. In respect to the formation of the committee, he claimed that his friends took matters into their own hands, without consulting him. Further, he stated that some of its members were known to him whereas others were not, that he had never met some of them. In the absence of being in charge of the proceedings, he had given written permission that every person could say what he chose about him. He was sure that the extent to which this was taken advantage of would not soon be forgotten by those who witnessed it.

Knox ended his letter by saying he could not judge whether the views adopted by the committee were right or wrong. If they were correct, he was willing to submit to the censure they had inflicted and would hold it his duty to profit from it and exercise 
due care thereafter. Candid men, would judge him according to the situation in which he was placed at the time and not on the basis of the wisdom which had unexpectedly been acquired since.

Knox continued teaching anatomy, in his establishment, after the trial. In 1829-1830, he commissioned Dr. William Fergusson to give demonstrations in surgical anatomy, a new innovation in anatomical teaching, and in January, 1833, Dr. John Reid joined the pair; together the three taught until 1836 in "Old Surgeon's Hall," with Knox presiding as high priest, oracle and philosopher.

In the session of 1836-1837, changes were made in his anatomical school. Fergusson's private practice and hospital duties increased to the extent that he could spare less and less time in the practical rooms and Reid assumed the lectureship in physiology at the University of Edinburgh. Knox now engaged his brother Frederick to assist him as well as some of his senior students. With these alterations, aided by the growing animosities of his contemporaries, his classes began to decrease in number. There were other factors involved as follows:

1. The want of anatomical material.

2. The advancing character of the Dublin and London schools.

3. The founding of provincial medical institutions.

4. An extended curriculum of study attended by greater expense and difficulties.

5. The glut in the medical market.

These developments also told, to some extent, on the prosperity of the other anatomical establishments in Edinburgh. Warburton's Anatomy Act did not work well in the north, that is, in Scotland, so that there was an inadequate supply of bodies available for general teaching purposes. The students began to protest and many went to Glasgow and Dublin. In comparing Knox and the University, the latter fared better in obtaining cadavers. In July, 1837, Knox applied for the vacant chair of general pathology at the University but failed in the attempt. In 1839-1840, he vacated Old Surgeon's Hall where he had enjoyed fame and popularity for ten years. He now joined the Argyle Square Medical School, as an anatomical teacher, which later united with the Extramural Lecturers; these then functioned under the name 
of Queen's College of Edinburgh. It was hoped that it would form a strong rivalry with the University. In 1841, Knox applied for the lectureship in anatomy to the art students of the Scottish Academy, which was vacant, but did not receive a single vote from the trustees of the Board.

The status of Knox reached a bad state in 1842. He began lecturing privately in anatomy in Edinburgh in November, but was unable to attract a class. In the following session, he attempted to give a course in physiology, with the same results. Public and professional confidence in him seemed to be lost and he could find no vacancy in his country. As a last resort, he unsuccessfully applied for the open chair of physiology at the University, first hurling depreciating remarks against his competitors for the position. Living in a sort of hand-to-mouth fashion, he finally died on December 20, 1862.

One of the factors which revolved around the performance of anatomizing human bodies during the period when the resurrectionists were in their heyday was the susceptibility of infection. Probably, the adverse feeling which prevailed against anatomists of that era might have been neutralized had the public been made aware of the dangers which existed when performing dissections. It took only the minutest drop of poisoned human virus entering an abrasion in the skin to quickly invade the whole system and cause death; this could occur in less than fifty hours. According to Lonsdale (1870), one or more incidents of infection occurred in the anatomical laboratory during every winter session; oftentimes men of great promise were victims. He stated that the dread influences and casualties surrounding this subject would fill a chapter of horrors. He mentioned that a Professor Christison and two of his colleagues, during a period of thirty-two years, treated upwards of 280 medical students for fever caught in the hospital wards, only a part of those who suffered. Lonsdale remembered four promising students who died from such during the month of November, 1837. It was calculated that of the 2,500 physicians practicing in Ireland, 500, or one-fifth, contracted typhus, or idiopathic fever as it was then called, and of that number, 127 succumbed. A large proportion of the cadavers which reached the dissection-room, were those who had died from this 
disease, so that there was always danger from contact with them. During the period of 1831-1832, cholera spread throughout the city of Edinburgh, causing such a high mortality among the population that a sufficient number of coffins and bearers could hardly be obtained to bury the dead. In spite of this, the Edinburgh anatomists accepted every unclaimed subject, even those coming directly from the wards of a hospital. For a period, Knox's dissectionroom contained none other than those holding the virus of this malady, yet, all this time, there was a clamor against the anatomists, particularly from the lower classes. Lonsdale (1870) stated that they were not only blind to their interests but could not evaluate, on a rational basis, the manifold benefits they received from the medical profession.

Nothing very spectacular happened in Scottish anatomy after the passage of Warburton's Anatomy Act. There is evidence that the schools have not always been able to obtain an adequate number of cadavers for dissection purposes. For example, during 1955 and 1956, they needed 262 cadavers, but obtained only 190 (Foreign letter, '57). 


\section{$[\mathrm{XV}]$}

\section{EARLY HISTORY OF ANATOMY IN NEW ENGLAND}

\section{$\mathrm{T}$}

he cycle of events in respect to human anatomizing, in America, has been different quantitatively but not qualitatively, when compared with that in Europe. What progress was made between the time of Vesalius in Italy and the Hunters in England, approximately a span of 300 years, developed more rapidly in the United States. However, the same series of events and struggles evolved in both places: hesitancy in developing adequate dissection laws, body snatching, indictments, high emotional feelings, riots and even murder, the last to a lesser extent. Here the problems were somewhat different. The country was colonized; it sought and succeeded in obtaining its independence; its population quickly expanded; it went through the Civil War and state after state was added to the Union. This necessitated more and more medical schools and students. Only minor Federal laws to regulate the obtainance of bodies have been enacted. Whenever medical schools were established within a state sovereignty, the legislators were confronted with a delicate situation; they either evaded the issue or formulated codes, which with few exceptions, were not ideal.

Between 1765 and 1957, an interval of 192 years, a total of 459 private or state medical schools have functioned at one time or another in the United States; of these, 81 have survived. A breakdown of the available data on the number of medical schools, freshman enrollment and the population is given in tabular form below:

\begin{tabular}{|c|c|c|c|}
\hline Year & $\begin{array}{l}\text { Number of } \\
\text { Medical Schools }\end{array}$ & $\begin{array}{l}\text { Number of } \\
\text { Freshman Students }\end{array}$ & U.S.Population \\
\hline $\begin{array}{l}1765 \\
1800\end{array}$ & $\begin{array}{l}1 \\
4\end{array}$ & & $5,308,483$ \\
\hline 1810 & 7 & & $7,239,881$ \\
\hline 1840 & 33 & & $17,069,453$ \\
\hline
\end{tabular}




$\begin{array}{cccc}\text { Year } & \begin{array}{c}\text { Number of } \\ \text { Medical Schools }\end{array} & \begin{array}{c}\text { Number of } \\ \text { Freshman Students }\end{array} & \text { U.S.Population } \\ 1875 & 80 & & 38,558,371 \\ 1901 & 159 & & 75,994,575 \\ 1905 & 163 & 3,373 & \\ 1910 & 144 & .4,234 & 91,272,266 \\ 1915 & 104 & 5,492 & 105,710,620 \\ 1920 & 88 & 6,457 & 122,775,046 \\ 1925 & 80 & 6,356 & 131,669,275 \\ 1930 & 78 & 5,794 & \\ 1935 & 77 & 6,523 & 150,697,361 \\ 1940 & 775 & 7,042 & \end{array}$

The ten states, which have had the most medical schools, are located in general, east of the Mississippi, and rank among the oldest; they are the following: New York, 45; Missouri, 45; Illinois, 44; Ohio, 40; Indiana, 27; Georgia, 20; Pennsylvania, 20; Tennessee, 19; Michigan, 16; and Massachusetts, 15. Arizona, Delaware, Idaho, Montana, Nevada, New Mexico and Wyoming have never had any. The number has not always been proportional to the state population. For example, Missouri, Indiana, Georgia and Tennessee have high values with a relatively low population.

The peak in the number of medical schools was reached in the first decade of the 20th Century when many private, flyby-night establishments existed; these had organized to make some quick money, particularly in their anatomical courses. About this time, they became a target for such standardizing boards as the American Medical Association and the Association of American Medical Colleges. These organizations were successful in eliminating the least stable and worthy of the group.

It is natural that more has been written about the oldest, medical institutions because, with the passage of time, they developed a background of traditions which has attracted the attention of historians. Most of the difficulties encountered in dissection occurred during the formative stages of medical education in America before satisfactory anatomical laws were developed in the various states. The following state regions will be highlighted: New England, Middle Atlantic, South Atlantic and East North Central. A list below gives the names of the schools about which most information is available together with the year each 
was founded. Probably more has been written about New England than any of the others.

1. New England
a. Harvard University-1782.
b. Dartmouth College-1797.
c. University of Vermont-1822.

2. Middle Atlantic

a. University of Pennsylvania-1765.

b. Columbia University-1767.

3. South Atlantic

a. University of Maryland-1807.

b. University of Virginia-1827.

c. Johns Hopkins University-1893.

4. East North Central

a. University of Michigan-1850.

b. Ohio State University-1907.

There are also data available on medical schools which had a transient existence and some attention will be given to them.

The exact status of human dissection in colonial times is difficult to determine. Records of such events are rare because there were no medical colleges or journals which existed during the period. The only other source of communication was by means of a few newspapers, which largely excluded such items, because of public antipathy to the procedure. There was probably more anatomizing going on than can be revealed. This was generally true of conditions elsewhere.

Since carly New England was governed by the common and statutory laws of England, there was nothing which provided any penalty for the exhumation of a human body. Removal of a garment or other apparel, however, constituted a felony under the underwritten law. A dead human subject, in itself, was and is still not legally regarded as property. Because of this situation, it became necessary for colonial assemblies to enact specific supplementary statutes to try and prevent body snatching.

One of the first legal codes established was that known as "The Body of Liberties," which was adopted in Massachusetts in 
1641. In essence, it stated that no man who was condemned to die was to be put to death within four days after his sentence unless the court saw special cause to the contrary, as in the case of martial law, nor should the body of any man so put to death be unburied twelve hours unless it be in the case of an "anatomy." It mentioned no penalty for the disinterment of human subjects. This shows that the bodies of executed murderers were available for dissection in New England shortly after the landing of the Pilgrims at Plymouth.

Outside of this statute, there were two others enacted which attempted to prohibit the disinterment of human bodies; one was in Rhode Island and the other in Massachusetts. As early as 1655, the assembly in the former state ruled that any person accused of robbing graves of bodies, who was found guilty in court, would be fined or suffer corporal punishment, or both (Waite, '45b).

In the early days, witchcraft was in the air, so much so, that in 1692, the Massachusetts Bay Colony felt it necessary to incorporate a major portion of England's Act of 1604 into its laws. This was done in an attempt to stop the practice of removing parts of the body for use as charms or in sorcery. The penalty for violation was death as a felony with loss of benefit of clergy and sanctuary. It was repealed in 1695 (Hartwell, 1881b).

A law which was adopted in the same territory in 1660, stated that a suicide is denied "the privilege of being buried in the common burying place of Christians, but shall be buried in some common highway ... and a cart load of stones laid upon the grave as a brand of infamy ...." Those taking their own lives were not made available for dissection in the New England Colonies (Waite, '45b).

Further evidence of the shortage of bodies for dissection is contained in the resolution of the Governor and Council of the Massachusetts Bay Colony, dated 1647. It stated that it was conceived as necessary to those students studying medicine and surgery to have the liberty, once in four years, to read and anatomize the body of a malefactor providing it was made available by proper decision of the court. This followed the familiar pattern developed previously in parts of Europe and it helped to estab- 
lish both a precedent for and a stigma against the practice in this country (Krumbhaar, '22; Waite, '45b).

The credit for the first dissection on man performed in the colonies goes to Giles Firmin, a physician and clergyman. He was in the Massachusetts Bay Colony from 1632 to 1646 , at first a resident of Boston and later of Ipswich. The anatomizing was conducted at the latter place in 1638, probably on the body of an executed criminal. He is supposed to have lectured in anatomy at Harvard, using a skeleton for demonstration. He returned to England; one of the reasons given was that he did not fare very well in his practice in this country (Viets, '30; Waite, '45b).

One of the men of this period, John Eliot, a famous Christian missionary to the Indians, was thinking in terms of establishing a medical school, even before 1650 . He attempted to teach the redskins anatomy and general medicine. This was done, because in trying to convert them to the new faith, he was always met with the same question as to what would happen when they were sick. In such cases, the savage method was to resort to the powwow or sorcerer. He found that even the most intelligent were so ignorant that they might profit by practical instruction in anatomy. In addition, he proposed the founding of an institution which would improve the medical education of young colonial students, who were receiving only theoretical knowledge, and who were forced to practice before they ever dissected. He stated that prior to his time the only anatomy which had been performed in the country was by Giles Firmin, previously mentioned (Ball, '28; Hartwell, 1881a; Krumbhaar, '22).

An idea of the lack of anatomical knowledge prevailing in the Massachusetts Colonies is indicated by an item in Judge Samuel Sewall's diary under the date of September 22, 1676. He, in conjunction with six others, at least one of whom was a physician, dissected, on September 21st, the body of an executed Indian. One member of the group picked up the heart and affirmed it to be the stomach.

Several decades before the Revolution, Dr. William Hunter delivered lectures at Newport, Rhode Island (1754-1756), which were attended by physicians and laymen. These were first advertised in the newspapers but no mention was made that demon- 
strations would be performed on dissected cadavers. It is possible that even though some favoring judge might have provided the body of an executed murderer so that human material could be presented, no publicity was made through the press, because of the hostility and antagonism that it would arouse (Ball, '28; Sabin, '34; Toner, 1874).

The scarcity of laws in Colonial New England indicates that the public did not suspect any great amount of body snatching. The members of the profession who were most interested in attending and performing dissections at that time were the physicians who were either preparing for surgery or serving as preceptors. Without medical schools, it was the latter who taught anatomy to apprentices in medicine. In order to obtain an adequate supply, it is probable that surgeons or their agents resorted to grave robbing. Such removals may have been in excess of what the public suspected.

Pertinent records point to the fact that very few bodies were made available to physicians in colonial times through legislative acts. Some students migrated to Europe in the early 18th Century to take advantage of more favorable conditions there. Thomas Bulfinch of Boston traveled to London to study anatomy under Cheselden. The same was true for Sylvester Gardiner of Rhode Island.

It was after the Revolution, when medical schools began to be organized in New England, that the public became more concerned with body snatching. In fact, they began almost immediately to associate this practice with these institutions. When Dartmouth College, in New Hampshire, proposed teaching medicine in the early spring of 1796, the general assembly of the state almost immediately passed its first law regarding grave robbing. It provided the following penalties: a fine not to exceed $\$ 1,000$, imprisonment for not more than one year, and public whipping not to exceed thirty-nine lashes, any or all of these to be imposed depending upon the discretion of the court. The last of these punishments, the thirty-nine stripes inflicted with a whip, goes back to Biblical times, the era of the New Testament. It was one less than the original forty applied by the early Hebrews, based on statements in the Old Testament. Since the Vermont 
border was only about a mile from Dartmouth College, that state felt it necessary to take precautions against resurrection, by agents representing the school, so the assembly enacted a statute with penalties similar to those in New Hampshire.

In 1804, Vermont went further and enacted a new code. Body snatching was made a felony and indictment and trial were in the hands of the higher county courts. The clerk of each tribunal was required to report all data to the state attorney general. For a period of two decades, between 1820 and 1840 , there were only seven indictments for "disinterring the body of the dead." Only two were convicted and punished (Waite, '45b).

By the year 1820, six New England states had laws against grave robbing. Collectively, the early ones had certain common penalties: fines, incarceration and public whipping, but the last was abolished in all codes revised after 1810. Variations in the types of punishment included fines from $\$ 100$ to $\$ 10,000$ and terms of maximal imprisonment from three months up to fifteen years. As the number of medical colleges increased, adding to student enrollment, the penalties became more severe. This was the method the legislators used rather than trying to provide a more adequate legal supply. In the earliest statutes, it was just as serious a crime to transport, conceal or possess a body removed from the grave as was disinterment. Possession was defined as being the presence of a body on the premises owned or controlled by the person accused.

In spite of various enactments, the great majority of illegal transactions were never discovered; if they were, the offenders were rarely apprehended, indicted or convicted.

The same preventive measures against resurrection were used here as in Great Britain: filling the graves with bundles of straw, sticks or large stones to make excavations difficult. This procedure delayed but did not prevent grave robbing. Thick planks were also placed across the coffins for the same reason which made it necessary to remove the soil from the entire grave, something rarely done. Such methods as the use of iron coffins or mortsafes were not utilized in New England or anywhere else in the United States, but public vaults constructed of heavy stone and iron doors were adopted. Grave watching was generally un- 
dertaken. In such cases, a man was employed to sit beside a grave from dusk to dawn; a shotgun was a necessity, to be used for protective or offensive purposes. This was kept up for ten nights, at the end of which, it was believed no one would want the body for dissection. His job was a vulnerable one in some respects. Attempts might be made to ply him with whisky either before or after he reached his post. In the former case, he might sleep off a jag after arrival. A few tales exist where a watchman was either bound and gagged or fired upon with bird shot.

The technique of grave robbing was complex and required much cunning to prevent detection, even after the job was completed. Notification of a prospective burial was usually sent by a former medical student in code either by mail or messenger, not directly to the head of a medical school, but to an apothecary, in on the deal, who would hastily impart the information to an anatomist. The grave had to be spotted and surrounding landmarks noted in daylight, so that it could be easily identified at night. This needed a person to do the reconnoitering. A proper conveyance was a necessity; the driver was instructed to appear on the scene of activities at a specified hour. Suspicion would be aroused if he loitered near the cemetery. At least, two ablebodied men were required to do the disinterment. Because friends of the deceased often marked the grave with stones, sticks or flowers, arranging them into a specific pattern, the surface of the grave had to be studied carefully so that such identifying marks could be restored.

In addition, two large tarpaulins were needed. All the excavated soil was thrown on one so that none would be left on the grass as a telltale sign. The actual digging was performed at the head end of the coffin, which could be determined by the placement of stone-markers, in a space about three square feet until the casket was reached. It was not usually difficult because the soil was loose, the grave being recently dug. By boring a row of holes into the fore end of the lid, it could be easily broken because the boxes were poorly constructed. The use of a saw or hatchet was contraindicated because of the noise factor.

Removal of the corpse was done by means of a hook placed under the chin. It was then placed on the second tarpaulin. An 
alternative was to strap a specially designed harness under the arms, with a ring in the back, to which a rope was tied. The clothing and any other apparel were stripped from the subject and thrown back into the grave; the body and all the tools utilized were wrapped and tied in the auxiliary canvas. Finally, the excavated soil was returned to the grave and the surface carefully restored as nearly as possible to its former state. An average time of one hour was required to complete the over-all job.

A dark lantern was an absolute necessity to carry out the proceedings and it had to be carefully shaded; this was usually done by setting it on a hook and placing the second tarpaulin partially over it. A bright light in a cemetery at night was a dead give-a-way and if seen would set off a general alarm, bringing a group of irate citizens to the scene.

The acquisition of bodies was seasonal, mostly from November to February, during the interval anatomical classes were held in the medical colleges and while the weather was cool. A body was dissected immediately for two reasons: embalming was not in use and there was always danger of discovery. In the United States, as in Europe, the graves of paupers were more attractive to the resurrectionists than others. These seemed to be fair game for body snatchers, whether amateur or professional. Public authorities were apt to be lenient and turn their heads in the opposite direction in such cases (Waite, '45b).

Some secrecy was maintained when a body was received at the medical college. First, all articles of clothing were burned, if they were still on which was unusual. Within a few hours, the skin of the head would be removed and all identifying scars or marks eradicated. This was done to prevent recognition in case the premises were searched. Since reparative dentistry was undeveloped during the early 1800's, fewer identifying characteristics could be discerned by means of the teeth. This custom, together with concealment of the body, usually made search for bodies by interested individuals unsuccessful.

Any visitor would probably have seen few subjects in places where dissection was practiced. Anatomies were performed quickly for obvious reasons. Usually students worked as steadily as possible so that the task was often completed within a week; 
they were excused from all lectures during this interval. When indicated, bodies were concealed in superstructures built on medical colleges: in domes, belfries or observatories. These spots were reached by means of a ladder through a trap door in the floor. Closure of the latter made the above appear inaccessible. A permanently installed, but hidden rope and pulleys permitted cadavers to be hoisted up and down at will. Wide chimneys with fireplaces were built in dissecting-rooms which were used to hide subjects when necessary. A block and tackle were likewise attached to the upper part of the flue for quick elevation of one or more cadavers. Chains were used on the pulleys rather than rope so that fires could be built when it was suspected that a search might be made; such suspended subjects suffered no harm except a little smoking. Receptacles, containing bodies, were placed in basements and covered with firewood.

One incident which developed outside of any medical school occurred in Ipswich, Massachusetts on a January night in 1818: a light was seen in a cemetery when snow was falling. Later, when it melted, a hair ornament was found, with a peculiar design, known to have been on the body of a young woman who was buried there a few days previously. An investigation was made: not only her grave was empty but also those of seven others which had been interred that fall and winter. The technique used in this resurrection was faulty in two respects: no shaded lantern had been employed and the body had not been wrapped in a tarpaulin so that, in transportation, the comb had fallen on the ground (Waite, '39, '45b).

The detective work, in this case, led the investigators to the doors of a local physician, Thomas Sewall. On his premises, were found the identifiable parts of three bodies which were being used to teach a group of students fundamental operative surgery. He was indicted on three counts but one was discontinued on plea of his counsel, Daniel Webster, that it was inaccurately drawn. The surgeon was tried and convicted on the remaining two and fined a total of $\$ 800$, probably the largest monetary penalty ever leveled against a body snatcher in the history of anatomy in this country. In this case, he happened to be an amateur instead of professional. The event was sufficient to ruin the doc- 
tor's local practice. Webster, who was a member of Congress, at the time, invited the physician to move to Washington, D.C. So successful was he there, that he became the personal physician of three presidents of the United States and was also instrumental in 1825 in founding the first medical school in Washington, the National Medical College (now George Washington University School of Medicine). 


\section{[XVI]}

\section{HUMAN DISSECTION IN THE MEDICAL SCHOOLS OF NEW ENGLAND}

\section{A. Harvard Medical School-A.D. 1748 to 1958}

$\mathrm{T}_{\mathrm{he}}$

he idea of organizing a medical school in Boston began to take shape within a small group of men in the late 1700's. As a beginning, a small collection of anatomical parts was made and kept in storage in the Harvard College Library. However, this edifice was destroyed by fire in 1764. Besides the medical books, two anatomical cuts and at least a male and female skeleton were lost. The latter had been presented to the institution by a Dr. Mead. A third skeleton, donated by Francis Archibald in 1748, may have fared similarly. In addition, a set of human specimens, in which the arteries and veins had been injected with wax were burned. An impetus to the concept of a medical school was provided when Ezekiel Hersey, a 1728 graduate of Harvard, bequeathed 1000 pounds in 1770 , to his alma mater to be used in establishing a professorship of anatomy and surgery. The founding actually took place in 1782 (Harrington, '05; Warren, 1860).

A leading light during the formative years of the Harvard Medical School was John Warren (1753-1815). It was his determination, ambition and exertions which supplied the essential driving force.

At this time, he was a marked man although only twentyseven years of age. A characterization of him is presented by Dr. Ephraim Eliot on the basis of his behavior, during one of the early meetings of the short-lived Boston Medical Society. Excerpts from his remarks are as follows: “. . . all were determined to put down Warren; but they could not; he rose triumphant over them all. Dr. Rand ... addressing himself to me, ... said, 
'Eliot, that Warren is an artful man, and will get to windward of us all. He has made a proposition to the club, that, as there are nearly a dozen pupils in town, there should be an incipient medical school instituted for their benefit; ... He has ... pro-

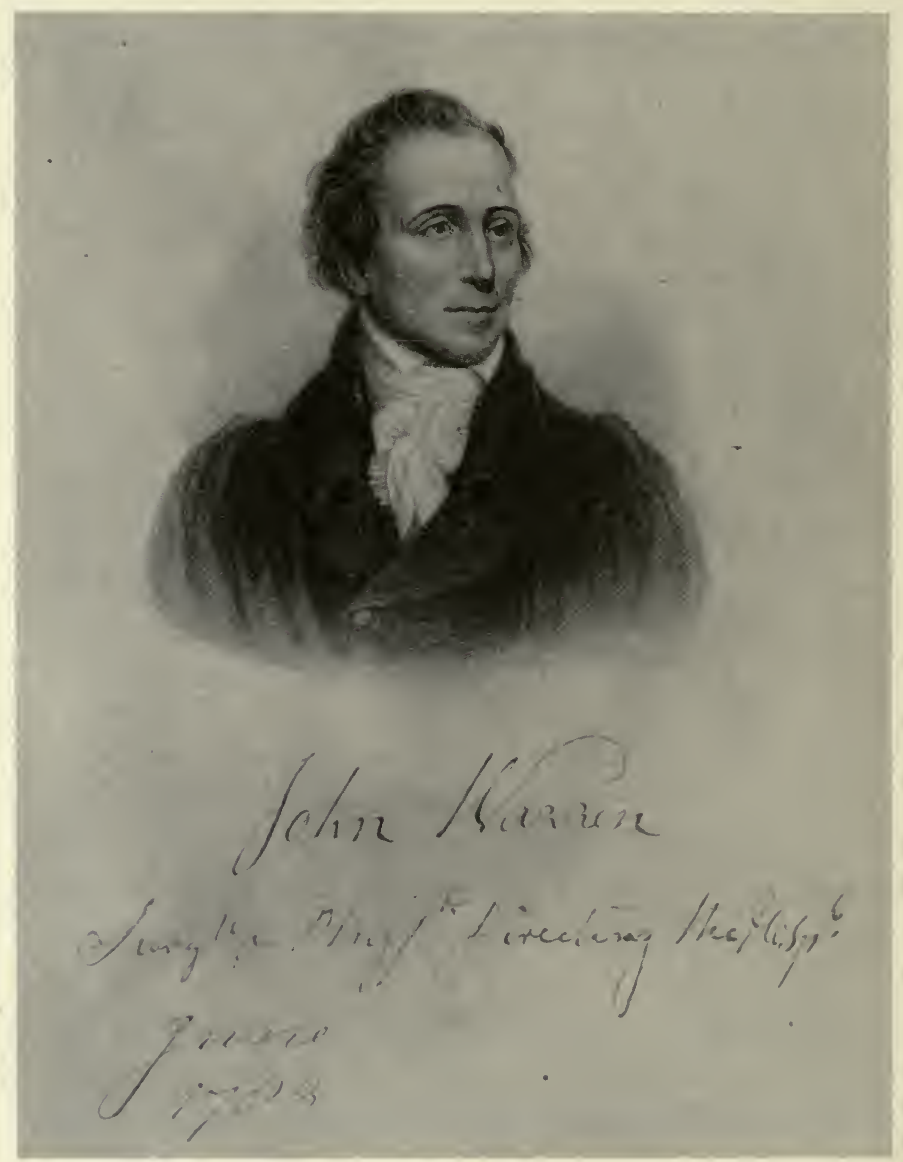

Figure 15. John Warren (1753-1815) as he appeared in June, 1783. From Warren, E.: The Life of John Collins Warren, M.D. Volume I. Boston, Ticknor and Fields, 1860.

posed some suitable person on anatomy and surgery. He was immediately put up ... ; and, after a little maiden coyness, agreed to commence a course, as he has many operations and surgical 
cases in the Continental Hospital, of which he is the sole director in every respect; and he can always have command of subjects for dissection, without exciting alarm, or being reduced to the necessity of taking bodies from the burying-ground, as most of the inmates of the hospital were foreigners, and no one would scrutinize into the matter. . . Now, Warren will be able to obtain fees from the pupils who will attend his lectures on anatomy and surgery, and turn it to pecuniary advantage. But he will not stop there: he well knows that moneys have been left to the college for such an establishment as he is appointed to, and he is looking at the professorship. Mark what I say, Eliot: you will probably live to see it verified"' (Harrington, '05).

From this, it appears that John Warren was not professionally popular; this was also manifest in other instances and it may have been due, in part, to the envy and pettiness of some less able colleagues.

He graduated from Harvard in 1771 and thereafter began to educate himself in medicine. Although he was largely selftaught, he served an apprenticeship for two years under the tutelage of his brother, Joseph. At no time, did he study under any great masters in science.

After serving in the Revolutionary War as a surgeon, he was appointed superintendent of the Continental (Military) Hospital in Boston. Before being elected to the Chair of Anatomy at Harvard, he gave a series of three anatomical demonstrations as follows:

1. In 1780, during the winter, he gave a course to Army and Boston physicians at the Military Hospital. This constituted the first attempt in that city to teach anatomy by demonstration. During these, he found it necessary to keep great secrecy because of the prevailing prejudice against dissection.

2. Warren conducted another session of anatomical demonstrations, in 1781, under the auspices of the Boston Medical Society. This was given publicly at the hospital and was attended by literary and scientific men, including President Willard, members of the Harvard Corporation and students from the college.

3. The third presentation was given, in 1782, at "Molineaux House," located on Beacon Street to an audience made up of the 
senior students at Harvard (Harrington, '05; Harvard Medical School, '06).

Elected professor of anatomy and surgery at Harvard, on November 22, 1782, Warren was inducted into office October 7,1783 . Immediately afterwards, he gave a six-weeks course in anatomy; it was held either in the basement of Harvard Hall or in Holden Chapel, with an enrollment of twenty students, who were required to obtain the consent of their parents. Twentysix dollars was the fee charged to new students, \$21 to seniors. This presentation was considered to be a novelty by the citizenry of Boston. Bodies for this instruction and his other demonstrations were not easy to obtain; when the resurrection men failed him, Warren obtained material as best he could, utilizing amputated parts from the hospitals.

The first and probably the only national law concerned with human anatomizing was passed by the United States Congress in 1790. It gave federal judges the right to add dissection when imposing the death penalty for murder (Hartwell, 1881a: Norwood, '44).

John Warren was a man of medium stature, well-proportioned physically and he carried a bayonet scar inflicted at Bunker Hill. He was dedicated to his profession and exhibited great energy, zeal, concentration and determination in those pursuits which he considered worthy. By some, he was regarded as impulsive, which may have been exaggerated by the rapidity of his mind and movements; these were characteristics which he maintained throughout life and were such that they probably did not endear him to his contemporaries. The decisions which he made were almost instantaneous both with his patients and others. A quality which overshadowed all others was his extreme sensitiveness to all suffering. He was able to overcome this while young with a natural youthful resilience but later in life it precipitated prolonged periods of depression, fostered by a somewhat weak constitution and physical infirmities. Politics and social events commanded some of his attention also and he was often called upon to submit articles or deliver orations expressing his viewpoints. Though not a democrat, he believed, in general, in equality among people. 
Apparently, he served as a sort of jack-of-all-trades at the newly formed Harvard Medical School. This led to the quip of Dr. Oliver W. Holmes later on that the Professorship of Anatomy and Surgery, which Warren held, was not so much a professorial "chair" as a "setee." This statement was merited because he simultaneously taught anatomy, surgery, physiology, and elements of pathology and histology.

Warren was of such disposition that he was constantly improving and perfecting his knowledge of anatomy and surgery. He was universally classified as an excellent lecturer; he appeared attractive to his students; he had a good voice, was enthusiastic, eloquent, earnest and, according to no less an authority than Holmes, could make the driest bone the subject of animate and agreeable description. He did not neglect the historical aspects of the subject especially concentrating on the "hero" personalities. Always anxious to please his students, he wanted them to feel satisfied with his demonstrations and explanations.

In his introductory lecture he showed the advantages that could accrue to the minister, the lawyer, the artist, the sculptor and the musician by having some knowledge of human anatomy. He stated, "It may be here observed that no previous medical knowledge is requisite for the perfect understanding of every part of our subject; and, let me inform you, that all the most eminent Anatomists have given it as their opinion that the reading of authors on this subject previous to dissections is by no means necessary, because books almost universally convey an imperfect idea of the situation of the parts, or, what is frequently the case, lead those who have not attended the Demonstrations into such errors as are exceedingly difficult to correct afterwards" (Warren, 1860).

At the conclusion of the six-weeks course, he addressed his students as follows: "The difficulties attendant on the prosecution of anatomical investigation in this part of the continent have been so great that only the most determined perseverance will be capable of surmounting them. It is, however, to be hoped that with the clouds of ignorance and bigotry those of prejudice and superstition will speedily be dissipated. We may yet hope for the happy day when that Profession which has for its object the 
most invaluable of all human blessings will cease to be treated with neglect and indifference, and the means of education preparatory to the practice of that profession which regards the lives of our fellow creatures, shall command an attention and countenance at least equal to that which has for its object the precarious tenure of interest and property ....

"The exquisite harmony and perfection by which the various parts of this complicated system are adapted to each other must fill us all with the most exalted ideas of the skill and wisdom of its architect. By inquiring into it and an acknowledgement of it, is a rational Tribute, to the omnipotent author.

"The investigation, by instructing us in the knowledge of ourselves, must evince the position, that Man has been the special care of Heaven. The structure of the body and the faculties of the soul are a full proof of divine attention and the consideration must inspire us with sentiments which will naturally be productive of worthy actions ....

"There is every excitement to diligence, perseverance, and believe me the present is the only time for laying in a sure foundation for its splendid superstructure ..." (Warren, 1860).

These views of John Warren suggest he held a profound reverence for the human body and its architecture and that he felt its anatomy was the keystone to medicine.

One of the fortunate consequences of the Revolution, from the standpoint of anatomy, was to dispel some of the public prejudice against human dissection. Between, 1782 and 1810, however, there was still some disapproval of the practice and many considered it a heinous and impious act. During the early part of his teaching career, Warren, found complete subjects for human dissection scarce and he had, of necessity, to use preserved, anatomical parts and other demonstration material.

Besides the bodies of a few executed criminals, an additional, though limited, supply was made obtainable in Massachusetts. All of the colonies had enacted laws against the practice of dueling during the 18th Century. In 1784, the state legislature revised theirs in a statute entitled, "An Act of Dueling." One of the provisions of this act was that a slain duelist should either be buried in a public place, without a coffin, with a stake driven 
through his body, or that it be given to a surgeon for dissection. Both were considered by the public to be a humiliating end. The winner of such a duel, if he killed his opponent, could be executed and his body treated in the same manner. A statute was enacted in 1805 in which dueling was included with murder and some other crimes. These were not strictly anatomical laws, for they were intended to add a further penalty and greater stigma to the crimes rather than to advance the study of anatomy.

The double legal source of bodies, those of executed murderers and duelists, provided only a small number between 1800 and 1829. There were about sixty executions in Massachusetts during that interval and all were not sentenced to be dissected. It is easy to see why the public placed anatomizing in close relation to major crime and considered it as a posthumous disgrace (Waite, '45b).

An unusual student, a resident of Quebec, by name of La Terriere, attended Harvard Medical School during the years 1788-1789. He was forty-five years of age and he made up the odd member of a total class of two; the other was Lyman Spalding, who later had much to do with the founding of the medical college at Dartmouth. The diary of La Terriere tells about the Harvard Medical School. He stated that the medical institution was fortunate and reaped a full harvest of four executed criminals for dissection during the academic session. Participating in a body snatching incident, he wrote of it in a sanguinary manner. He began by describing the death of a fat, old spinster who was followed to her grave. After the funeral, he and his colleagues bribed a greedy caretaker who consented to let them abscond with the body the same night. To make it easier for the amateur resurrectionists, the sexton covered the coffin with only a light layer of dirt. Because he carelessly left a shovel lying close by, the relatives discovered the thievery the following morning and immediately created a furor, demanding that a search warrant be issued by the governor. As a member of the medical class of two, La Terriere was suspected; he gravely suggested that the head of the state was also a member of the Harvard Corporation which was enough to squelch the matter. He is known to have commented afterwards that, in his opinion, the woman was a superb specimen. 
After graduating, La Terriere returned to Quebec where he carried on a private practice. This incident indicates that students were active in body snatching about forty years prior to the passage of the Anatomy Act in 1831. However, encouraged by reports of the success of resurrectionists in Great Britain, certain men began to appear on the scene who were willing to produce interred bodies for the right kind of remuneration (Harrington, '05).

The pace John Warren set for himself in attempting to maintain his private practice, his professional and social duties, as well as other personally imposed standards, began to tell on him. He requested in 1793, that the Corporation allow John Fleet (M.B. degree, 1788), an assistant, to perform dissections, which was granted. Still later, 1808, he suggested that an adjunct professor be appointed to assist him and that he should be paid an identical salary and have similar duties. His son, John Collins Warren, who had received his medical training in Europe, was appointed to this post on April 27th of that year. Up to that time, the elder Warren had made his course at Harvard, the best in America. After a long-standing heart condition and a full but somewhat difficult life, he succumbed on April 4, 1815, at the age of sixty-one.

John Collins Warren, like his father, graduated from Harvard. This was in 1797, at the age of nineteen. He then studied under his parent for one year. Following this, he spent time in Europe: in London, Edinburgh, Holland, Belgium and Paris.

He began his anatomical activities in Boston in 1805 by opening a dissecting-room at 49 Marlborough Street (now about 400 Washington St.). As mentioned previously, he was appointed adjunct professor of anatomy and surgery at Harvard in 1809 and head of the department in 1815. He retained this position for thirty-two years. All told, he was active as a surgeon-anatomist for forty-five years.

John C. Warren was regarded as a superior dissector, possessive of an excellent personality, strict with himself and others and devoted to anatomy both as an art and science. He probably 
did not have the natural teaching abilities of his father, lacking his voice, but he was more broadly educated.

Among the biographical notes left by John C. Warren, are remarks made regarding the procurement of subjects. In the early part of his dissecting career, he said, this caused him a great deal of trouble and anxiety. After the Revolutionary War, great difficulty was experienced in obtaining cadavers. Occasionally, bodies of executed criminals and paupers were available, averaging not more than two a year. Even before he graduated in 1796, he began the business of acquiring specimens. As a medical student, he went on a body snatching party.

On this expedition, he described setting out for the North Burying Ground, reaching it at ten o'clock on a rather light night. They soon located the pertinent grave but being unsure about it, went to another place. On examining this, they found themselves in error and returned to the original site. One of the group was put on guard while the others worked rapidly. When the coffin was reached, they broke open the cover, which revealed a stout young man. The body was taken out, put in a bag and carried to the cemetery wall. As they were about to lift it over, a stranger was spotted on the other side, walking along the edge of the barrier smoking a pipe. A plan of action was formulated by the gentlemen resurrectionists. One of the group, feigning intoxication, accosted the man, entered into conversation with him and then started a quarrel. A second member of Warren's party appeared, pretended to side with the stranger and ordered the supposed drunk to go about his business. Taking the unwanted man by the arm, he led him off to a safe distance and then returned to the burying-ground. The body was then quickly hoisted over the wall, put in a two-wheeled carriage and carted off to Cambridge. Warren and a friend stayed behind to fill the grave and efface the vestiges of their labor. His companion, however, not relishing the task, left the scene before it was completed (Warren, 1860).

When the elder John Warren learned that his son had been engaged in this episode, he was very much alarmed but when he saw the fine healthy-looking subject that had been obtained, 
he was highly pleased. The cadaver lasted throughout the entire course.

When John C. Warren opened his private laboratory at 49 Marlborough Street, an adequate supply of bodies was obtained for a number of years with the aid of students. As other medical schools were opened in New England, pupils were sent from Cambridge to Boston to procure subjects and apparently made exhumations in a careless way. The suspicions of the police were aroused; they took all preventive measures possible and watchers were hired to guard the cemeteries. This resulted in a scarcity of subjects. Agents were then sent on expeditions to regions located outside of the community, some going as far as New York City. The latter was expensive and constituted a great hazard. Two or three times, resurrectionists foraging for cadavers in that city, were seized by the police and brought to court. Some were judged guilty and punished by a small fine, since the officers were liberal. Constant efforts were necessary to carry on this business.

Still another incident was mentioned by John C. Warren, which concerned two of his medical students. Both were described as being remarkable for their strength of body and mind. He requested them to obtain a subject for dissection to which they readily acquiesced. Spotting a pauper from an almshouse being buried at the cemetery on the Neck, in Boston, they marked the plot with a stick which could be easily identified. Shortly after midnight, noting that the watch had departed, they opened the grave, removed the cadaver, and then refilled the excavation. A young man whom Warren labeled " $F$ " then went to town to obtain a wagon which had previously been engaged. The second, designated as " $T$ " remained in the vicinity to act as guard. When the vehicle returned, a concealed group of watchmen sprang upon them, seized " $T$ " and attempted to arrest " $F$." The latter, however, evaded them, leaped upon the cart, lashed the horse and went off at a gallop, dragging several watchmen with him for some distance; they were finally dislodged and the driver continued on into the country since his horse was headed in that direction.

The student "T" who had been apprehended, was con- 
ducted by two of the policemen through Washington Street (then Orange Street) towards the nearest watchhouse. Seeing an opening in a fence, he suddenly disengaged himself, dashed through the aperture, leaped down an embankment into a great open space. Because of the semi-darkness and lack of paths, he was successful in evading his pursuers. The chagrined watchmen now sprung their rattles, filled the air with their cries and set all the bells ringing throughout the town. The escapee plodded his way through marsh, water and ditch, chuckling to himself and enjoying the clamor. On reaching Western Avenue, he scaled the wall, walked deliberately toward the tollhouse where he stopped to pay the fee. He questioned a number of men standing by what the commotion was all about. After surveying him closely, one grasped him by the shoulders and claimed him as a captive. These were the guards from whom he had previously freed himself, who had preceded him there and awaited his approach.

Once more a prisoner, " $T$ " was marched toward the police station. At the corner of Beacon and Charles Streets, he said to his captors, "Why are you treating me in this way? I have done you no harm." This was enough to divert the attention of the men. Taking advantage of this, "T," with a strong effort tore himself loose, sprinted through an open space between Chestnut and Mount Vernon Streets and was able to leave his pursuers a good distance behind. A third policeman, on beat, alerted by the clangor and observing a man running, seized him at Willow Street. Without giving this officer a chance to question him, " $T$ " struggled violently, released himself and dashed off again. Coming to a partially constructed house, he threw himself into a mass of shavings and covered himself up. The searchers tramped around the place but were unsuccessful in discovering him. They finally gave up the hunt, following which " $T$ " rested, caught his breath and returned home without further interference.

His companion, " $F$ " drove around quietly in the country, amusing himself until morning, when he returned unsuspected to town. John C. Warren described him as living thereafter in good health and prosperity, as one who practiced medicine for humanitarian reasons, merely as a sideline to a more lucrative business. 
"T," on the other hand, did not fare so well. The exertions made in the running from his pursuers, together with the strenuous efforts in freeing himself from his captors, precipitated a hemorrhage from his lungs. Although a stout and well-formed man, he had a recurrence of the complaint, followed by cough, tuberculosis and eventually a premature death. Warren stated that he was a man of elevated character, thought his passing was a loss to society and that he fell a victim of the narrow-minded prejudices existing at the time. Further, he wondered if the masses had not reverted to primitive times of superstition and witchcraft.

John C. Warren cited the case of another pupil of his who had a propensity for procuring subjects and liked to work alone. He was picked up by the police while in the South Burial Ground, during the late evening, looking for the grave which he had marked during the day. Taken to the station, he was released on the condition that he appear at the courthouse the following morning. When the session convened, he listened quietly to his accuser's charge of intent to body snatch. Then, he broke out into a tirade, accusing them of conspiracy to extort money, of attempting to ruin his reputation and threatening them with action. The watchmen were astonished by this attack and became meek. In analyzing the situation, the judge could not find an act of illegality and so discharged him. This particular student eventually obtained his medical degree and settled in Mexico City, where he established a practice (Warren, 1860).

Outside of these difficulties, both major and minor, John C. Warren highly enjoyed dissecting and making anatomical preparations for demonstrations for himself, his students and any others of the profession who might be interested. It became his primary occupation and his chief pleasure; he regarded it as an agreeable relaxation from his professional pursuits and in one sense, his daily meat and drink. The practice held more charms for him than games, plays or parties.

It is interesting that John C. Warren was one of the first in the United States to utilize the embalming method for the preservation of cadavers. He first used a combination of rum, arsenic and corrosive sublimate. By this method, he was able 
to preserve subjects for many months. He described one specimen as being in a well-preserved state after eight years in spirit. During his tenure as professor of anatomy and surgery, he built up an anatomical collection of considerable proportions which gained wide acclaim and recognition.

John C. Warren was such an unusual individual in his field that a few remarks on his character may not be amiss. He is described as having possessed a highly excitable temperament, a keen sensibility to impressions of pain or joy, impulsive tendencies, which were controlled by habits of reserve. He seemed to delight rushing into danger and taking the lead from love of excitement, whether it was to a fire, a bread-riot or what not; yet, he was ready to listen to the first words of calm reason. His greatest trait was that of unwearied industry in which each exertion required a separate psychological effort. No moment was lost in an occupation which seemed worthless. With his patients, he never gave a hasty opinion nor did he answer a frivolous question or risk an erroneous explanation. His manner with students was restrained and he often regretted the quick uttering of an impetuous word which wounded the feelings of those around him. Although he never seemed to notice things or words foreign to his immediate interests, his eyes and ears encompassed everything about him.

Throughout his life, J. C. Warren exhibited great tenacity of purpose in any pursuit he chose to follow. An old friend was a friend forever, never forgotten. He indulged but little in petty conversation, amusement or social intercourse. Although not an obstinate man, a maxim, once adopted, was never altered except for the strongest reasons, yet he could yield gracefully when he thought it was wise to do so. Rigid economy was practiced in all of his financial transactions, both trifling and large because he believed this was the only way a person could be prosperous in his affairs. Religiously speaking, he had been educated to a firm and reverent belief in the Scriptures and in their full inspiration; the Sabbath was rigidly observed and church regularly attended. Finally, he loved to dwell upon pictures and memories of the past which probably stemmed from his pride in his English heritage and his interest in his illustrious ancestors. 
A report on the evolution of the Massachusetts Anatomy Act of 1831, the first in the United States, and in the English speaking world, may not be amiss, at this time, because of its importance to the Harvard Medical School. It portrays how much difficulty can be encountered in the passage of such a statute. Prior to this year, the public had become acutely conscious that body snatching was more common than had been suspected and the hostility against dissection and medical colleges had increased. Individual physicians and some groups had asked the legislators to provide adequate relief but had met with little success because the lawmakers were cognizant of the well-known popular aversion to anatomizing. Bills had been introduced by physician-members of the House and Senate but never got beyond committee consideration.

The medical profession of the state had long desired an adequate legal source of material for teaching practical anatomy. The primary stimulus for this opinion was probably the series of events which had occurred in Edinburgh, notably the Burke and Hare murders. However, local events also served as an added incentive, notably an episode of resurrection occurring in 1818, in Ipswich, which was climaxed in the indictment of Dr. Thomas Sewall, a local physician; he was found guilty and fined $\$ 800$ (c.f. Chapter XV). Much credit must be given to Dr. Abel L. Peirson of the Massachusetts Medical Society who took the lead in advocating that a committee from that group be appointed to seek legislation. He introduced such a resolution on February 4,1829 , which was accepted; he was appointed its chairman and devoted much time and effective effort to the work. Each member of the profession was asked to do his best to personally influence his local and state representatives. The first bill was introduced in January of 1830. The committee report stated the following: it "did not think it expedient to propose any alteration of the laws at the present time; because in a community like ours, it is necessary that laws should proceed from and be supported by public opinion" (Waite, '45b).

The next step taken by the Medical Society was to educate the public. Articles signed by members of its committee were published in the newspapers. A pamphlet advancing arguments 
for the necessity of such a law was printed and 10,000 copies were distributed throughout the commonwealth. A second bill was introduced at the next session of the legislature in May, 1830. The Governor spoke in favor of providing better facilities for teaching anatomy. A special committee of the lawmakers then reviewed the bill but it was postponed until the following year. It was passed in the January session, 1831, under the title, "An Act more effectively to Protect the Sepulchres of the Dead and to legalize the Study of Anatomy in Certain Cases" (Waite, '45b). It can be classified as the first, effective anatomical law in any English speaking country, antedating the Warburton Anatomy Act of England by fifteen months. The Massachusetts law was somewhat improved by amendments in 1834. It had added significance because it influenced the neighboring New England states in formulating similar codes.

One of the main arguments advanced by the proponents of the Massachusetts bill was that adequate legal provision for human dissection would benefit the poor as follows: without satisfactory instruction in practical anatomy, open to all, the American physicians who were trained abroad in areas where material for dissection was plentiful, would charge higher fees on their return to this country.

The new statute permitted civil officials to surrender bodies, for anatomical use, that must otherwise be buried at public expense, with some exceptions; this was a forward step beyond the previous limitation to the bodies of executed criminals. It was defective in two paramount considerations: it was not mandatory since it only granted permission to civil officials to release bodies for dissection at their "discretion; it forbid the use of the bodies of any stranger, town pauper, or person who during life had signified that his remains be buried or any individual whose body was requested to be interred by kinsman or friend (Harrington, '05; Waite, '45b).

A dearth of anatomical material continued for some time after the passage of the Anatomy Act of 1831. About the year of 1836, a shortage, in this respect, existed which led the Harvard faculty to petition the Mayor and Board of Aldermen against 
allotting bodies for dissection to any other person or organization during their academic sessions.

Although Oliver Wendell Holmes (1809-1894), who succeeded John C. Warren, has been classified as a man of letters, rather than a great anatomist, there were certain events which transpired during his academic career at Harvard Medical School worthy of mention. He served as chairman and professor of anatomy between 1847 and 1882. Prior to that he held the same titles at Dartmouth, 1838-1840; spending fourteen weeks there annually at a salary of $\$ 400$. Of the many events in his productive life, only those relating to his anatomical career will be chronicled.

Holmes described his introduction to medical school as follows: "I have been going to Massachusetts General Hospital and slicing and slivering the carcasses of better men and women than I ever was myself or am like to be. It is a sin for a puny little fellow like me to mutilate one of your six-foot men as if he were sheep, but vive la science" (Knox, '07). This was during the fall of 1830 when he was twenty-one years of age. In the spring of 1833 , he went to Paris to complete his medical education where he made further human dissections; there he found that subjects were easily obtained and cheap. He paid 50 sous for one, about 50 cents in the then prevailing currency, and he said that it could be cut into one-inch pieces by nightfall. Specimens were also available, upon which, surgeons in training could perform trial operations. It was not a trifling matter to be a medical student in Paris, he found. Before breakfast each morning, he was required to attend an hour and a half lecture followed by a tedious dissection. To give an idea of the scope of the anatomizing rooms at the École de Médicine, he said they would accommodate 600 students. He was so much impressed with the spaciousness and cleanliness there that he mentioned, by contrast the "little infernal, suffocating holes in which the unhappy native of our uncivilized land is often obliged to pursue his labors" (Tilton, '47).

By some, he was not regarded as a great anatomist but as probably the best lecturer in the country on the subject. In the latter respect, his students remembered him as being witty, humor- 
ous, bright and cheerful in disposition. He was successful in robbing the material of dryness, even when describing bones, yet he was concise, exact, clean-cut and employed a scholarly rhetoric. In other traits, he was careful, conscientious, punctual and painstaking. Although he was given the last lecture hour of the day, he could hold the attention and interest of a weary class continuously week-after-week. As an example of his manner of dressing up a statement is the following: about the female pelvis: "gentlemen! this is the triumphal arch under which every" candidate for immortality has to pass" (Miscellany, 1894). Apparently, he was enthusiastic when excellent preparations were made by his students. President Eliot of Harvard made the statement that he had never "heard any other mortal exhibit such enthusiasm over an elegant dissection." He rewarded his demonstrators with high praise when they performed excellent work.

As a professor of anatomy, he had a particular liking for the old masters of anatomy. He was tolerant of their misconceptions, caught the quaintness of them and handed them down to his students ever more unique by the transmission (Dwight, 1894). To the pioneers, he felt we owe much and he was understanding of their merits and limitations. He was able to trace the evolution of a theory or doctrine from a vague origin to its ultimate development or collapse. Harmony was something he liked and he was able to keep himself free from professional jealousies.

All anatomical exams, given during his tenure, were of the oral type and he seemed to adjust them to the individual he was quizzing. At one of these, he asked William James, who later became famous, to describe a small nerve in the head. When it was answered correctly, Holmes said, "If you know that, you know everything! Now tell me about your dear old father" (Tilton, '47). His approach to examinations was very casual which probably tended to neutralize any tension built up on the part of a student. On the question of admission of women in medicine, he did not take a decided stand but voted with the majority of professors in the negative. He said he was willing to teach anatomy to women, but in classes and dissecting-rooms separate from the men. 
The following is another anecdote in the teaching career of Holmes quoted from Abbot (1895). "In my early student days in the Tremont Street Medical School, after a recitation in anatomy to Dr. Holmes, at which I happened not to be present, he sang to the class a new song of his own composition-probably one of his humorous medical productions, but of this I am not quite sure. Two days after, while he and I were engaged together in the dissecting-room, I casually remarked, "I greatly regret not being present at the last recitation in anatomy." "Why?" he asked. "Because I lost the song you were so kind as to sing to the students." After a moment's pause, with his head turned down a little towards one shoulder, and a peculiar compression of the lips-an attitude and expression of the mouth which all his old friends will remember, he said abruptly, "Would you like to hear it?" "Why, of course, doctor, I should," was my reply. "Well, I'll sing it to you," was his immediate response. So he laid down his scalpel and forceps, and standing facing me, with the poor relic of humanity on the table between us, he began, and went through the whole of it, with as much enthusiasm as if he were singing to a thousand people. After the prolonged applause of his audience of one had subsided, he said, "Do you like it?" "Why of course, doctor," said I, "no one could hear it without liking it." "Well," said he, "it is good. No one but a fool would pretend he doesn't know when he has done a good thing."

Besides holding the professorship of anatomy at Harvard, Holmes was dean of the medical school (1847-1853); he was selected to present the University Lecture (1863-1864) and was overseer of Harvard (1876-1882).

During his tenure as a professor, there had been some agitation concerning supposed abuses in dissection. This had occurred in spite of the fact that the Anatomy Act of 1831 had been in use for a half-century. After his retirement, Holmes was selected as one of the speakers in dedicating a new medical building on Boylston Street. The faculty had taken every precaution to prevent the public from inspecting the dissection-room. To their consternation, Holmes concluded his remarks by inviting his audience to visit the quarters in question. This shows that he was open and broad-minded on the subject of anatomizing. 
One of the many obituaries written after Holmes' death in 1894, which reveals a part of his character, was published as an editorial in the Boston Medical and Surgical Journal of that year. A part of it is quoted as follows: "He grew old so quietly, so sensibly, so judiciously, so gracefully, that it was difficult for those in occasional contact with him to realize that he was a very old man" (Editorial, 1894).

\section{B. Berkshire Medical College-A.D. 1823 to 1869}

The chief rival of Harvard, during the early medical history of Massachusetts, was considered to be Berkshire Medical College, located in the western part of the state at Pittsfield. It survived for forty-six years. The founding of that institution was made difficult due to an incident which happened in 1820. In that year, the body of George Butler, Jr. was stolen from a local grave under circumstances unknown. The citizens, on hearing of it, arose en masse and demanded that the offender be duly punished. With this event fresh in everyone's mind, the school was established with some apprehension.

During the years of its survival, it was generally believed that all cemeteries in the immediate vicinity were periodically invaded by resurrectionists, both amateur and professional. At first, the trustees of the medical school did everything possible to assure the public that preserved anatomical parts and a course in comparative anatomy furnished excellent substitutions for fresh dissections. Apparently, the populace adjusted to the situation so that human anatomies were eventually carried on with the support, financial as well as moral, of the townspeople. One thousand one hundred thirty-eight physicians were graduated from this institution but it had to close its doors in 1869 due to lack of clinical facilities (Norwood, '44).

\section{Castleton Medical College-A.D. 1818 to 1861}

In January of 1824, the Board of Trustees at Castleton Medical College in Vermont publicized a resolution that no subjects removed from cemeteries within the county would be used for the teaching of anatomy. It stated that the supply would be 
furnished from the large seaports in the neighboring states. This meant a considerable transportation problem since the nearest sizeable harbor was about 200 miles distant. It was usual for all medical colleges to have rules forbidding dissection but they weren't necessarily observed; they were made primarily to mislead the public. Dissection material was undoubtedly obtained from nearby graveyards in this case (Waite, '45c).

Castleton Medical College became involved in the following incident, called the Hubbardton Raid: In 1830, 300 men from neighboring Hubbardton marched on the school because the grave of a woman, in their community, had been found empty. The mob surrounded the building, entered the premises and after a search found a headless body hidden in the wainscoting. During the siege, a student walked through the crowd with the head, wrapped-up and hid it in the hayloft of a neighboring barn. The entire matter was settled without an arrest being made when both parts of the corpse were returned for reburial (Waite, '45a).

The college offered a summer course in anatomy. In the catalogue, this was written up as follows: "It is especially the design of this institution to offer facilities and means so ample for the acquirement of a thorough knowledge of anatomy that county students shall not be compelled to resort to the cities at an increased pecuniary expenditure and the exposure of health and morals" (Chapin, '51).

\section{The University of Vermont School of Medicine- A.D. 1822 to 1958}

The University of Vermont School of Medicine is one of the oldest in the United States, being founded in 1822. Throughout its history, it has had a chronic and troublesome problem in obtaining anatomical material, particularly in its early days. In 1804 , the state formulated a law making it a felony to rob graves. Vermont physicians, in 1835, made an unsuccessful attempt to have a suitable law passed but it wasn't until 1870 that judges were permitted to assign the bodies of executed criminals to medical schools. The state led, however, in enacting a mandatory code in 1884 which directed that any body buried at public expense, whether from town or state institution be surrendered for 
the promotion of anatomical science. Certain subjects were excepted. A written application by a licensed resident, physician or surgeon was necessary (Chapin, '51; Waite, '45b).

In 1825, the fee charged for the course in anatomy at the University of Vermont was $\$ 14$, which was paid to the professor in charge. It was considered a part of his duties to provide cadavers as best he could.

Between 1820 and 1840 , dissection was carried on at the University of Vermont and two other medical colleges within the state. Seven hundred ninety-two students were graduated in medicine by these institutions during this interval. In addition, there were about 800 others who attended anatomical classes but did not complete their medical education in Vermont; still others studied separately under preceptors. It was estimated that about 400 cadavers were utilized by the combined groups. This averaged twenty per year. In the medical colleges, six students commonly dissected on one specimen and fewer with a preceptor, often only one. The law provided only one or two subjects annually so that practically all had to be procured illegally; most were obtained within the confines of the state. Since there was conviction for only one body snatching in two decades, it shows that detections of grave robbing with punishment of the offenders were rare. Disinterments were sometimes discovered many years later when attempts were made to remove the remnants of bodies from places of original burial to some other location (Waite, '45a).

There is an instance where a student became a professional resurrectionist in order to help defray his expenses at the University School of Medicine. That was in 1872 (May, W. S.: The Country Doctor, quoted by Chapin, '51). His method was to disinter a body in a distant community and send it to the college via train. One of his removals was discovered by friends of the deceased who went to the college, and identified the body. Suspicion rested on the man in question who left the school and disappeared from the region. When things quieted down, he returned, completed his studies and graduated.

Another story, told by and involving Dr. A. V. Bowker, 1879, (quoted by Chapin, ' 51 ) is as follows: he was ordered by one of the doctors to take a horse and wagon and pick up a 
package arriving at the depot, it having been shipped by train, via express. Arriving late, he was reprimanded by the station manager. The parcel, in a coffin, was put on the cart and he started toward the University of Vermont. He was met by the local mailman and interrogated; although he feared that the police might be informed, the parcel was delivered safely to the institution. Bowker wondered how the physician, who served as a teacher in a girl's Sunday School class, in a Methodist Church, could get mixed up in such a business.

The same author tells of another incident where he was told to get a barrel of onions arriving by train. It was taken to the school, where he with the help of other students, knocked in the top of the container. When this was done and the subject revealed, it was obvious that it had died of smallpox. As a precaution, all of the students were vaccinated the next day.

A few years later, 1882, the bodies were described as being in very poor condition at the University of Vermont Medical School, making it difficult to perform presentable dissections. It has been reported that by 1894 , each student was required to purchase his own cadaver (Chapin, '51).

Even after the turn of the century, secrecy prevailed in the handling of subjects. In 1903, the old medical college caught fire. The day before this catastrophy, dissection had been started in the rear room of the upper floor. The students rushed in and carried the cadavers down the stairs and outside. There they were placed in mattings, carpets or anything serving as a covering and transferred to a barn nearby. Extreme care was taken to prevent observation by the crowd watching the conflagration in front who probably would have been more interested in what was going on behind the building.

To give an idea of the value placed on laboratory assistance, it can be mentioned that a student, at Vermont was paid 50 cents each for taking care of cadavers, that is, injecting them and putting them into tanks for preservation. When needed for anatomizing, they were hoisted up by means of a block and tackle through a shaft connecting the tank room with the dissectionchamber. 


\section{E. Vermont Medical College at Woodstock-A.D. 1827 to 1856}

This institution, located temporarily in southern Vermont, had trouble in getting organized; some citizens opposed the founding because they felt it would lead to grave robbing in the region. The issue of the charter was delayed when applied for in 1827. It was "hindered by prejudiced or inimical persons; no nearer patronage could be procured than that of the college at Waterville in the state of Maine" (Waite, '45c). Degrees were not issued until 1830 so the school was academically impeded for two years.

When it was announced in July of 1829 that it would reopen, an endeavor was made by the faculty to reassure the public as follows: "We pledge ourselves to the community that we will not use or suffer to be used in any manner as far as may come to our knowledge any human body that may have been disinterred hereabouts; it may appear invidious to set limits but we are willing to say the state of Vermont. We are well assured of obtaining competency of the means from remote parts and in a manner that ever will be justified by the well-informed and judicious part of the community" (Waite, '45c). They agreed to name three prominent citizens who would be allowed access to the medical building at any time. This promise may have been written with one eye directed toward the New Hampshire border which was only thirteen miles away. Graves could be pilfered in the adjacent state with impunity because the sheriff there had no authority in Vermont.

One year later, 1830, Woodstock became implicated in an episode involving the disappearance of the body of Polly Chamberlain from her grave in Barnard, ten miles distant. When the loss was discovered, irate citizens marched on the medical school, searched the premises, but were unable to find what they were looking for. Because of circumstantial evidence, four students were arrested, then taken to Barnard for questioning by the justice of peace. Two were released, the other pair being held for trial in the County Court at Woodstock on June 10, 1830. The trial was continued from early morning until 11:00 P.M., in a jam-packed courtroom. The verdict rendered was not guilty. 
This institution was also involved in another affair which borders on the unusual and may indicate the plight of the anatomists for suitable teaching material. Two brother students at the medical college were accused of body snatching, in March of 1834 , by the people of Burlington. This implied that the body was transported over primitive roads, a distance of ninety miles, something of a feat in those days. John Daggett, aged eighteen, and his elder brother, were arrested and brought before a magistrate who bound them over to the grand jury. Two indictments were returned against each for "disinterring the remains of the dead" (Waite, '45c). When the disputed body was returned, one indictment against each was quashed by order of the attorney for the state. Both were convicted and sentenced, on the second count, to serve three years in the Vermont State Prison. The older brother completed the full term, whereas the younger was pardoned and discharged after a little more than two years. The latter returned to the Woodstock School of Medicine and graduated in June, 1837. This is, apparently, the only case on record in the New England states where a student was sentenced to a state prison.

In respect to this incident, the following letter is quoted from Waite ('45c) because it reveals the feelings of the 125 citizens of Burlington who signed it:

"(To the Faculty of the Medical College at Woodstock, Vt.) Gentlemen:

The examination of John F. Daggett, bound over for a trial at the next term of the County Court, recently a student in your institution, as well as very intelligible intimations from him since his trial renders it certain, in the opinion of the undersigned and of this community, that the body of Mrs. Holbrook late of this place was removed to Woodstock and is now in your College. Mrs. Holbrook was, and her family are highly respectable; and the disinterment of her remains has occasioned to her relatives a distress which you can properly appreciate, and is universally regarded as a vile outrage which will not be submitted to unless the laws have lost their power to punish.

"Information upon which we rely renders it probable that the dissecting knife has not been used upon her remains; and the 
undersigned submit to you, Gentlemen, whether your duty to the publick does not demand that her body be restored. We are unwilling to believe (sic) that Gentlemen so respectable as the Faculty of the Woodstock Medical School would countenance in the smallest degree an outrage of the kind-and although we fully believe that the true character of the outrage was unknown to you at the time, and would be indignantly reprobated by you at any time, yet we can have little doubt that your endeavours to procure the restoration of the body would be successful, and probably would be the sole means of effecting it.

"We ask, therefore, your assistance and believe it will be granted, as due to justice, to the feelings of a family lacerated for the means, the atrocious motive of gain, to public opinion and to the character of your institution.

Yours respectfully,"

At Woodstock, the cost of cadavers was $\$ 15$ which sum constituted no profit to the school because the wages to the resurrection men or demonstrators in anatomy were relatively high. No fee was charged for the use of the dissecting-room. Any anatomizing was completed in seven to ten days because embalming was unknown in such a rural school as Woodstock and searches by the officers of the law were always impending (Waite, '45c). 


\section{[XVII]}

\section{HUMAN DISSECTION IN THE MIDDLE ATLANTIC STATES}

$\mathrm{T}$ wo of the biggest centers of medical education in the United States have been in Philadelphia and New York City. Probably more is known of the early history of the former.

\section{A. The University of Pennsylvania-A.D. 1750 to 1958}

Philadelphia was the scene of the first course given in anatomy in America (1745-1751). The lecturer was Thomas Cadwallader, but it is unknown whether he employed cadavers for demonstration.

William Shippen, Jr. (1736-1808) was a figure who stood out in the early history of anatomical dissection in Philadelphia. It was he who, at the age of twenty-nine, became the Head and Professor of Anatomy and Surgery at the University of Pennsylvania School of Medicine, the pioneering medical school in the United States (1765). He prepared himself for this position by training under John and William Hunter in London in 1761 and teaching anatomical courses in Philadelphia between 1762 and 1765 .

After training under the Hunters in London, Shippen returned to Philadelphia and started teaching what has been called the first systematic anatomy course in North America. An announcement of his proposed instruction, appeared in the Pennsylvania Gazette on November 11, 1762. On the 16th, he gave an introductory address at the State House, which was well-attended by the intelligentsia of the city; subsequent lectures (1762-1765) were given in a private laboratory in his father's house. His course was a landmark in anatomical history in the United States for he was the first to teach in true Hunterian style, in- 
structing his pupils in the art of dissection (Hartwell, 1881a; Middleton, '32; Packard, '33).

The academic life of Shippen was at first intimately associated with that of John Morgan regarded as the principal founder of medical education in America. The latter is described as having been impulsive, fervent, positive and a statesmanlike organizer, whereas the former was judged to be calm, cautious, far-seeing, self-possessed and at times subservient to a crafty nature (Middleton, '27).

The paths of Shippen and Morgan crossed in Britain, where they had studied together in part, under the Hunters; there the pair probably discussed the possibility of establishing a school in Philadelphia. On returning to America in 1765, Morgan presented a plan for organizing a medical department before the Trustees of the College of Philadelphia. It was approved and on May 3rd of that year, he was elected to the first professorship offered, that of, Theory and Practice of Physic; upon application, Shippen was appointed Professor of Anatomy and Surgery (Packard, '02).

John Morgan had this to say about anatomy: "It is Anatomy that guides the doubtful steps of the young votary of medicine through an obscure labyrinth, where a variety of minute objects present themselves in such a group as, at first to perplex his imagination ....

"As a skillful pilot informs himself of the last bank of sand or shoal where he is to avoid navigating his ship; so every follower of medical pursuits should be intelligent in the minutia of Anatomy, if he wishes to practice with ease to himself, and to the benefit of the patient..." (Middleton, '27).

The first cadaver that Shippen received was that of a Negro who had committed suicide by cutting his throat with a broken glass bottle. He immediately encountered difficulties because the citizens of the city were not used to tolerating dissections of human bodies. They became suspicious that graves were being robbed; opposition developed, a mob formed and attacked his anatomical lab in 1765; windows were broken with stones and a musket ball was shot through his carriage, with the mistaken idea that he was in it. Shippen escaped through a back alley. The 
violence, in this case, was precipitated by transient sailors, rather than by the solid citizenry of Philadelphia; for that reason, it has been labeled the "Sailor's Mob." At other times, Shippen had to flee his own dwelling (Hartwell, 1881b; Middleton, '32; Norwood, '44).

Shortly before he started his anatomical courses under the auspices of the College of Philadelphia, which was on November 14,1765 , Shippen felt it in order to put a notice in the Pennsylvania Gazette on October 31st.

"It has given Dr. Shippen much pain to hear that notwithstanding all the caution and care he has taken to preserve the utmost decency in opening and dissecting dead bodies, which he has persevered in chiefly from the motive of being useful to mankind, some evil-minded persons, either wantonly or maliciously, have reported to his disadvantage that he has taken up some persons who are buried in the Church Burying Ground, which has distressed the minds of his worthy Fellow Citizens. The Doctor, with much pleasure, improves this opportunity to declare that the Report is absolutely false, and to assure them that the bodies he dissected were either of persons who had wilfully murdered themselves, or were publickly executed, except now and then one from Potter's Field, whose death was orving to some particular disease, and that he never had the body from the church or any private Burial Place" (Middleton, '32).

Shippen moved into new quarters in 1765, at Anatomical or Surgeon's Hall, on North Street, which were quite an improvement on the ones previously occupied. The building was 100 by 70 feet and belonged to the College of Philadelphia. He taught there from 1765 to 1806 , except for the Revolutionary War years of 1776-1777, when he served as Director-General of the Military Hospitals. His classes increased in number from 12 to 250 , the greatest numerical growth being between 1769 and 1775. The charter of the College of Philadelphia was revoked due to Tory activities: At the time when the school was reorganized and taken over by the University of Pennsylvania, 1791, there were 104 students in attendance. These figures show that his course was an exceedingly popular one. 
The relationship between John Morgan and Shippen came to a sad ending. A discord developed between them when the former, the original appointee as Director-General of the Military Hospitals, was relieved of the post and replaced by Shippen. There had been a number of complaints against the manner in which Morgan loosely handled the care of the sick and wounded. Among the critics, was Shippen, who wrote to a member of the Continental Congress, that more soldiers were dying from neglect of medical care than by the sword. This led to a considerable amount of friction and eventually distrust between them and the breach created never narrowed; in fact, it developed into a violent hatred. Morgan was exonerated by Congress in 1779. In 1781, re-elected to his former professorship, he refused to serve on the same faculty with Shippen. The position was kept open for him until the year before his death in 1789 (Middleton, '32).

Shippen died on July 11, 1808, at the age of seventy-two. The last part of his life was saddened by the death of his son whom he was training to follow in his footsteps.

Another anatomist, Abraham Chovet, a contemporary of Shippen in Philadelphia, is mentioned because of the contrast in the method of his teaching. The span of his lectures extended between 1774 and 1783. Previous to this, he had taught in London. Eschewing human dissection, he relied entirely on wax figures and charts which he made himself. He advertised the use of these in the newspapers and emphasized that his curriculum was free from the disagreeable sight of putrid human corpses. His course was very popular and some considered him a better anatomist than Shippen. John Adams wrote that his models were excellent, being better than the Fothergill Collection in the possession of the Pennsylvania Hospital, which were used by Shippen. Chovet's reproductions were purchased in 1793 by the same hospital and added to the above group. All were destroyed by fire in 1888 . Little is known of the life of Chovet: he was born in 1704, place unknown, and probably was a demonstrator in anatomy at the Barber-Surgeons Hall, London, in 1734. There he taught beginners in anatomy before they started dissecting, a minor role. From London, he went to the Barbadoes, then Jamaica, from whence he migrated to Philadelphia (Miller, '11). 
Shippen was succeeded by Caspar Wistar, who trained under him. A year before he assumed the chair of anatomy (1805), Wistar was giving a demonstration to the medical students, at which he had asked a Quaker student, by name of Joseph Parrish, to assist him. At this session, Parrish wore his Quaker hat in the pit, an act which prompted the medical class to hiss him; the teacher immediately came to his defense, explained the significance of the situation, and praised the man for his religious principles. The assembled students took the explanation in good stead and thereafter showed respect to Parrish (Middleton, '42).

Wistar was a well-trained anatomist, having studied at both Pennsylvania and Edinburgh, where he obtained his M.D. degree in 1786. He was a born teacher and his success was immediate on returning to America. A part of his efforts was devoted to collecting models, casts and preparations for a museum. He stressed the need of each student possessing a set of disarticulated bones, which was an innovation. Published under his name was a text entitled, A System of Anatomy for the Use of Students of Medicine, in two volumes, 1811-1814. It remained popular as an American text for many years.

He became famous as a professor and was able to fascinate his audience with his powers of description. His subject matter was treated philosophically as well as anatomically. In harmony with this, he endeavored to cultivate literary people. Attracted to his famous Sunday Wistar parties, were the intelligentsia of the region; these sessions were later continued by the American Philosophical Society. He left his anatomical collection to the University of Pennsylvania; they now form the nucleus of the Wistar Museum. He taught at this institution between 1791-1818 (Mettler, '47).

Following this, there was an interval in which the chair of anatomy at the University of Pennsylvania was held by John Syng Dorsey and then by his uncle, Philip Syng Physick. William Edmonds Horner (1793-1853) succeeded to the position in 1831. His character stood out because although he presented a calm exterior, he possessed a sensitive soul; he practiced self-accusation and depreciation and frequently suffered severe mental anguish. 
Serving as a surgeon in the War of 1812 , he found the horrors therein appalling.

Horner became renowned for his skill at dissection. In 1816, Wistar made him responsible for the preparation of the anatomical specimens used in his course. He was given an annual salary of $\$ 500$ which served as a real boon. His lectures lacked eloquence; he resorted to statements of fact and was painstaking in presenting them. For thirty years, he served as dean of the school and, under his direction, it maintained the highest standards in medical education. He was also a very successful surgeon (Middleton, '23b).

Horner was succeeded by Joseph Leidy (1823-1891), who became one of the greatest naturalists this country or perhaps any other has ever produced. As a youth, he was often called, "a queer boy" (Middleton, '23a). On his first exposure to dissection, Leidy had this to say: "I was so disgusted with the dissectingroom that, after spending the first half-day there, I went away and could not be induced to return for nearly six weeks, and I did not get entirely over the melancholy produced for a year. Then the desire to acquire information gradually overcame my repugnancy, but so far was I from shaping my course for myself that I never gave up the idea of sometime forsaking the dissectingroom, until I was elected to my present position as professor of anatomy" (Middleton, '23a). Philip Syng Physick, who preceded him, also had some distaste for practical anatomy; both were sensitive and scholarly anatomists.

Leidy became well-known for the magnificence of his dissections and the students held him in high regard. He was gentle, kind and taught anatomy as a pure science; his demonstrations at the cadaver table, formed the most useful unit of his teaching as his voice carried poorly in his lectures. A natural believer in evolution, he constantly emphasized man's biological place in nature. In appearance, he looked like a conventional Christ. He had a splendid head, deep-set, pensive blue eyes with almost straight, overhanging eyebrows. In stature, he tended toward stoutness since he carried 200 pounds on a five foot, ten inch frame and he walked in a stooped manner. He was not interested in wealth and he led a quiet and unpretentious home 
life. In disposition, he was very amiable, friendly, generous and charitable, honorable, direct, innocent of guile and incapable of deceit. At times, he could be quite emotional about things and he was fond of music. In his pursuits, he was persistent and diligent throughout his life and was always careful in the economy of his time. He won a place for anatomy as a science in America. Apparently, he was loved by all, as he was given a tremendous funeral (Middleton, '23a).

Pennsylvania passed its first anatomical law in 1867 (Hartwell, 1881b). It has since become a model for other states. Yet, it did not abolish grave robbing entirely. As late as 1883 , there was an incident in this respect. In that year, a drunken, worthless soldier living in Easton, Pennsylvania, committed suicide by hanging. Some trouble was encountered in giving him proper rites but he was finally buried in a pauper's cemetery in Easton.

The evening of interment, Samuel D. Gross, a practicing surgeon in Easton, called a student from the University of Pennsylvania, who was home on a visit, into his office and said, "Green, I want that fellow." That night, at a late hour, Gross, Green and another student marched to the cemetery with a wheelbarrow and spade. They located the grave in a remote corner of the potter's field, where the soil was rough and undulating. They set to work to unearth the coffin but the shovel made so much noise that Gross said, "Green, we had better quit or we'll get caught." So they stopped, filled up the grave and left the premises. A few days later, a brother of the deceased soldier, with the mistaken idea that the body had been stolen, met Green in the street and said, "Doctor, I believe you got my brother's body." The student responded with the enigmatical answer, "You can believe what you please." This closed the incident (Rohrer, '12).

\section{B. Early Dissection in New York-A.D. 1750 to 1790}

Going back to colonial times (1750), the body of Hermanus Carroll, a criminal executed in New York City, was injected and dissected by Dr. John Bard and Peter Middleton; this was used for medical instruction and was performed under legal sanction (Ball, '28; Ladenheim, '50). 
It became customary to make public announcements of courses to be given in practical anatomy, that is, dissection, in New York newspapers. The man who first had the courage to do this was Thomas Wood. The means of communication was the New York Weekly Postboy, dated January 27, 1752.

It was written as follows (Krumbhaar, '22):

"Whereas Anatomy is allowed on all Hands to be the Foundation of PHYSICK and SURGERY, and consequently, without SOME knowledge of it, no person can be duly qualified to practice either: This is, therefore, to inform the Publick That a COURSE of OSTEOLOGY and MYOLOGY, is intended to be begun, some Time in February next, in the City of New Brunswick, (for which Notice will be given in this Paper, as soon as the proper number have subscribed towards it). In which Course, all the human BONES will be separately examined, and their Connections and Dependencies on each other demonstrated; and all the MUSCLES of a human BODY dissected; the Origin, Insertion, and Use of each plainly shown. This Course is proposed to be finished in the Space of a Month.

\section{Thomas Wood, Surgeon}

"Such Gentlemen who are willing to attend this Course, are desired to subscribe their Names as soon as possible, with Mr. Richard Ayscough, Surgeon, at New York or said Thomas Wood, at New Brunswick, paying at the same Time, THREE POUNDS, Proc. and engaging to pay the Sum of Three Pounds more, when the Course is half finished.

"N.B. If proper Encouragement is given in this Course, he proposes soon after, to go thro' a Course of ANGIOLOGY and NEUROLOGY; and conclude, with performing all the OPERATIONS of SURGERY, on a dead body: The Use of which will appear to every Person, who considered the Necessity of having (at least) SEEN them performed, before he presumes to perform them himself on any living Fellow Creature."

Several incidents occurred in New York City which caused great excitement and attracted wide attention. In the late 1700's, the greatest opposition to dissection existed among the poorer classes, including Negroes. The reason for this was that grave 
robbers most often combed pauper cemeteries chiefly because they were buried closely together, often without coffins, which made it easier to remove them. There was also greater leniency toward thefts there.

In 1763, a Negro who was found guilty of rape was executed and subsequently dissected by surgeons interested in anatomy. This was a few years before the founding of King's College (1768). The organization of this school was the aftermath of a course given in anatomy by Dr. Samuel Clossy, beginning in 1763; this individual became professor of anatomy there. It later merged with the College of Physicians and Surgeons (1814), which was founded in 1807 (Davis, 1877; Ladenheim, '50).

During the winter of 1788 , reports circulated throughout the community that grave robbing had been committed both at a Negro cemetery and from the one at Trinity Church. This precipitated a series of letters to the editors of newspapers, which stirred up the feelings of the populace. These apparently conditioned them so that they were in a responsive mood on the occasion of a specific incident, the "Doctor's Riot," which occurred on April 13, 1788. The following is an account of the events: Three boys were playing near the hospital when one climbed a ladder and looked into the laboratory window, where several students and an instructor were dissecting a cadaver. A Dr. Hicks either hung up an arm to dry, waved it at the peeking child to frighten him away, or held it before his face and told him it was his mother's arm (the boy's mother had in fact recently died). The lad fled in terror and reported the incident to his father who visited the grave of his recently deceased wife and found the coffin open and the body missing. He returned to his fellow laborers, who, armed with tools marched toward the hospital. Adding numbers as they proceeded, they entered its south wing and broke into the dissecting-room. There they found some partially dissected bodies which they carried away and buried that evening. Hospital property was wrecked. Rioters were sent out to capture the physicians who were involved. Dr. Hicks managed to escape, but his four companions were apprehended; they were saved from immediate violence by the mayor and sheriff who put them in jail for safety. The following morning a crowd col- 
lected before the hospital, looking for Dr. Hicks, without avail, and then searched the homes of other physicians for evidences of dissecting material.

The governor, mayor and chancellor, who had assembled, appealed for order but were for the most part ignored. The mob went to the College of Physicians and Surgeons and swarmed through the building but found nothing. By afternoon, 300 to 400 persons had gathered before the jail demanding the doctors. Later the assembly, which had swelled to about 5,000 began to storm the prison; the attack was put down only after the militia resorted to extreme methods: shooting and killing eight rioters. On the 15th, two days after the affair started, the military group was reinforced. Although the city was alive with excitement, the riot was not resumed. Later in the day, the soldiers held a parade.

Afterwards public sentiment ran so high that newspaper advertisement of physicians were withheld for about ten days. Several of the surgeons, known to be dissectors or suspected of being implicated, publicly disavowed any connections with graveyard desecrations. Members of the profession tried to persuade the public that the cadavers utilized were either condemned prisoners or Negroes taken from cemeteries remote from city limits. Their words went unheeded and anxious relatives flocked to check on the graves of their loved ones. For a long time, there were reports of "Dead Guard Men" protecting new graves (Davis, 1877; Hartwell, 1881a; Ladenheim, '50).

The New York State legislature soon after (1789) passed an act to prevent the odious practice of digging up and removing bodies interred in cemeteries for the purpose of dissection. The penalty for so doing was corporal punishment. It also provided that those executed for murder, arson or burglary, if unclaimed, or given by relatives, could be used for dissection. 


\title{
[XVIII]
}

\section{HUMAN DISSECTION IN THE SOUTH ATLANTIC STATES}

\author{
A. The University of Maryland Medical School- \\ A.D. 1790 to 1958
}

$\mathrm{T}_{\text {he }}$

he activity in respect to early dissection, in the South Atlantic States, centered around Baltimore, particularly the University of Maryland School of Medicine, which was founded in 1807.

One of the first to teach anatomy in this vicinity was Dr. C. F. Wiesenthal. Dissections were carried on in a rear room of his residence located on Fayette Street; considering the time, his laboratory was well-equipped. In the year of 1788, he obtained the body of Patrick Cassidy, an executed murderer, which was put in the hands of his students. A mob, formed of certain citizens of Baltimore, attacked his establishment and took the subject by force (Cordell, '03).

The year 1807 was a signal one in Maryland, because certain events led to the development and organization of the University of Maryland Medical School. Dr. John B. Davidge, who graduated at Glasgow, in 1793, erected a small anatomical building, in Baltimore, obtained a cadaver, and immediately started teaching. When the populace, which consisted of about 8,000 people, learned of this venture, a crowd gathered and totally destroyed the structure. Great prejudice existed in Baltimore and this type of violent action was generally approved. In this instance, the physicians of the state rallied to the support of Dr. Davidge, and drew up a charter for the purpose of founding a medical school. The attempt was successful since it passed the legislature within two weeks. Davidge was elected dean and professor of anatomy. His first lectures were held in his home, but were discontinued 
when a suitable building was erected. The new edifice was ornamental and a credit to the city; it still stands as the oldest extant in America, having been in continuous use for almost 250 years. With its completion, anatomizing was resumed, but was done under stealth. Concealed dissecting-areas behind the sloping seats in the anatomical theatre were used when necessary. Also included in the construction were hidden exits, stairways and cubbyholes in anticipation of surprise attacks by irate citizens (Figge, '57).

The second professor of anatomy at the University of Maryland was Granville Sharp Pattison, who would stand out as an interesting character in any period. He arrived in America from Scotland with the understanding that he would become professor of surgery at the University of Pennsylvania but when he discovered that this had been given to William Gibson, he migrated to Baltimore, taking with him an extensive anatomical collection, which had evidently been bequeathed to him by Allen Burns of Scotland. These, he sold to the University of Maryland for the price of $\$ 8,000$, a large amount for that time, which is indicative of the scarcity of this type of material. Some of his collection still exists and is used mainly for exhibition purposes.

Pattison was probably best known for his behavior in a clash with Dr. Nathaniel Chapman of the University of Pennsylvania. This may have been associated with the fact that he had been rejected in respect to the chair of anatomy and surgery at that institution. At any rate, Chapman circularized pamphlets of a malignant nature against the character of Pattison. Being a man of strong emotions and prejudices, the latter responded in like manner, publishing denials attempting to show that the claims were false. So emotional did he become that he issued a challenge to Chapman to a duel.

Invading Chapman's territory in Philadelphia, Pattison took the offensive and boldly posted a notice in two public places, as follows (Figge, '57):

\section{"To the Public}

Whereas Nathaniel Chapman, M.D., professor of theory and practice of medicine in the University of Pennsylvania ... has 
propagated scandalous and unfounded reports against my character, and, whereas when properly applied to has refused to give an explanation of his conduct or the satisfaction which every gentleman has a right to demand, and which no one having claim to that character can refuse, I am, therefore, compelled to the only step left me and post the said Dr. Nathaniel Chapman as a liar and a coward and a scoundrel.-Granville Sharp Pattison."

For this announcement, Pattison was arrested. The challenge to a duel was refused by Chapman on the grounds of his age, a large family and the obligations of his position. He wrote, "It really would seem, under any circumstances not quite fit to have introduced my course of lectures with the spectacle of a duel. . . . With Mr. Pattison it is entirely different. He is an adventurer with a tainted reputation, which he hoped to repair."

This was not the end of the affair. The feud continued for several years. Things came to a climax when Pattison openly and publicly insulted Chapman before his brother-in-law, General Thomas Cadwalader. A duel with pistols, was arranged and took place somewhere in Delaware. Both parties displayed great coolness, but Pattison came off the victor, wounding Cadwalader in his pistol arm near the wrist. The ball traversed the entire length of the forearm and lodged in the head of the ulna. Cadwalader put a shot through the skirt of Pattison's coat near the waist (Figge, '57; Miller, '18).

The University of Maryland was one of the first medical schools, in America, to make human dissection by medical students compulsory. This practice was instituted in 1833 about the same time it was adopted at the University of Edinburgh. By 1850 , of the sixteen medical schools in the United States, only three required anatomizing. Introduced at this time also was the installation of gaslights in the anatomical laboratory which enabled pupils to work on bodies in the evenings. It wasn't until 1882 that Maryland passed an anatomy act; however, before that Baltimore was being called the "Paris of America," because of the adequacy of its anatomical supply (Figge, '57).

The only known "burking" in the United States occurred in Baltimore, in 1886. It became a famous case and involved a well-known woman by the name of Emily Brown; she was the 
daughter of a respectable innkeeper who lived on the eastern shore of Maryland. This lady had the reputation of being a welleducated and charming southern belle. When her father passed away, she moved to Richmond where she kept house for her brother for eleven years. Following his death, she gradually deteriorated and at the age of fifty, drifted to Baltimore where she

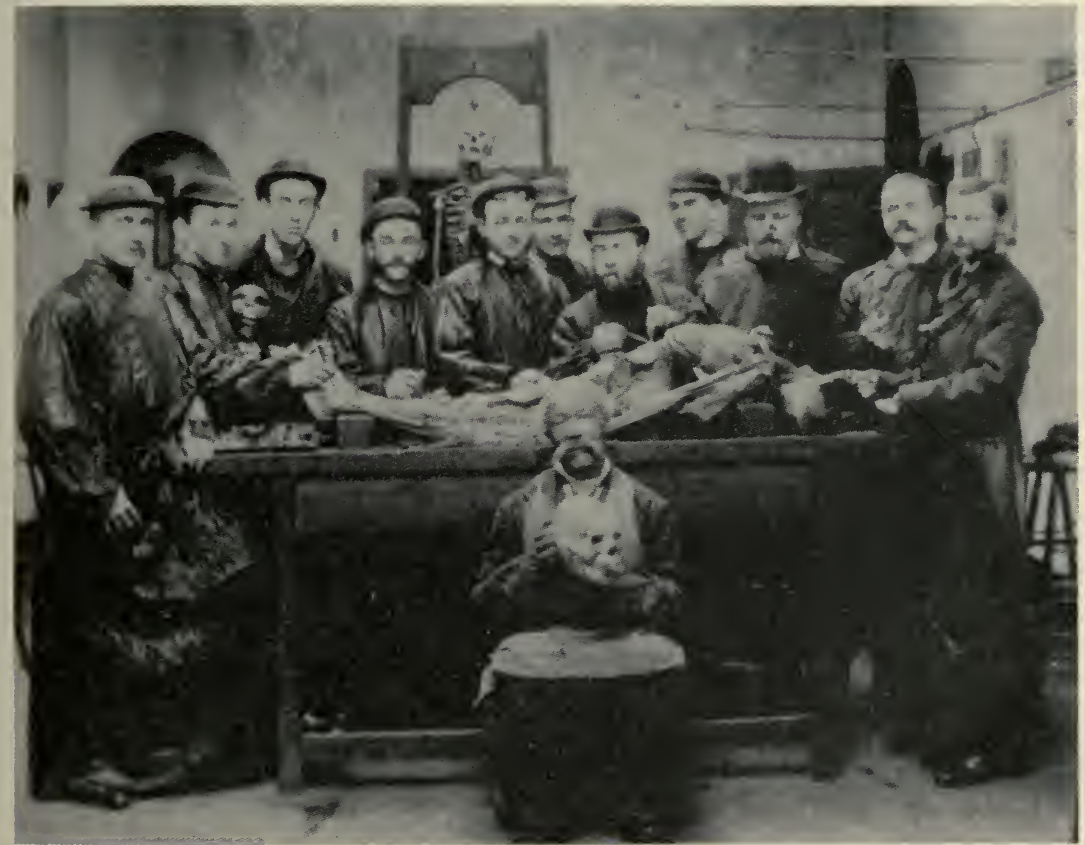

Figure 16. A photograph of an anatomy class at the University of Maryland, taken about the time of the passage of the first Maryland anatomy act (1882). From Figge, F. H. J.: Anatomy 150 years ago. The Kalends, 36:11-14, 1957. By permission of Professor Figge and The Williams \& Wilkins Co.

walked the streets, frequently under the influence of drugs and liquor. Destitute, she began living with a Negro family in one of the poorest sections of the city. In this residence, lived a Negro man, John T. Ross, who served as porter in the dissecting-room at the University of Maryland. He, with the help of another Negro, strangled her because, as a corpse, she was regarded as 
saleable. Her body was sold for $\$ 15$ to the University of Maryland. On receipt, the condition of the subject aroused suspicion, the police were called in to investigate, the murderers were apprehended, convicted and hanged on September 9, 1887 (Ball, '28; Guttmacher, '35).

The 1882 Anatomy Act of Maryland did not function effectively as far as providing sufficient cadavers was concerned. The anatomical professors signed a petition in 1888 to modify the act, claiming that shortages prevailed and that they had to rely on body snatching. This led to the introduction of a bill in the state senate providing for the use of bodies of tramps and vagabonds. The teachers suggested that it be amended so that friends of deceased persons could not claim subjects for burial. In March of 1890, a State Anatomical Board was formed, partly precipitated by the "burking" incident quoted above (Cordell, '03; Kelly, '08; Sabin, '34).

Franklin Mall, selected as the Head of Anatomy at the newly formed Johns Hopkins Medical School, complained that the anatomical law of Maryland was inadequate. He wrote on November 15,1893 , that, "The problem now changes from teaching anatomy to obtaining cadavers for a new school." He used only three for sixteen students during his first term. One of those, he said he got at the "risk of his life" (Guttmacher, '35). By the end of the year, however, he was obtaining enough through legal channels.

In 1897, Dr. Jones, the new Health Commissioner of Maryland, ordered all bodies turned over to the Anatomical Board for disposal. If they were not claimed for educational purposes, they had to be buried at public expense. In the four years prior to this, the average number received by Mall per year was fortyfour. During Jones' tenure, it rose to 185. The last subject acquired in Maryland by illegal means was in 1899. The anatomical law of 1882 was revised in 1938 and again in 1949 (Figge, '57; Guttmacher, '35; Mall, '05).

\section{B. Washington, D.C.-A.D. 1865 to 1900}

The history of dissection in Washington, D.C. was described in 1896 , by Dwight, as being particularly bad and disgraceful after 
the Civil War. He cited the instance of 500 students, distributed among several schools, dissecting bodies, all of which had been obtained illegally. He claimed that the experiences of the NorthSouth conflict taught military suregons how important anatomy could be. The sentiment began to undergo a change, thereafter, becoming more favorable toward the practice of dissection. After the hostilities had ceased, Washington became infested with resurrectionists and they did a large volume of business. One, by name of Janssen, was frequently arrested, particularly because he was bold enough to raid the better class cemeteries. His activities ranged as far as Baltimore. In the capital city, he stole the body of a hanged criminal and sold it to a medical school; the next night he re-stole it with the intention of selling it to another institution but was caught with the booty in his hack. After serving the term of his sentence, he had the temerity to give daily lectures in one of the smaller theaters in Washington, using a dummy as a sham corpse. During his activities in Washington, the police were kept so busy that the ordinary course of business was badly disrupted. The medical schools finally combined to make up a purse to induce Janssen to depart from the region; this is probably the only case of such an instance on record. His final arrest for grave robbery was made in 1884 .

It wasn't until 1902 that the United States Congress created an Anatomical Board consisting of the district health officer, two members from each medical school, one from the postgraduate school and one from the medical school of the Army and Navy. The board had to be notified of all unclaimed persons dying within the District of Columbia and they had to be apportioned to the medical institutions according to the number of students enrolled each year (Correspondence, '02).

\section{Dissection in Virginia-A.D. 1830 to 1865}

In Virginia, the legislature refused to sanction the dissection of executed murderers, so that it was impossible to anatomize legally (Hartwell, 1881a; Krumbhaar, '22). A pioneer in the teaching of practical anatomy there was Augustus L. Warner. He gave lectures on this subject in a private dissecting-hall located at 
the rear of the University of Virginia, at Charlottesville. The course started on November 5, 1830 and was continued for four months. A fee of $\$ 10$ was charged students for the privilege of anatomizing. This teacher was held in high regard and made a great reputation for himself.

Warner was appointed Professor of Anatomy, Physiology and Surgery at the University in 1834 , and began his duties there with an enrollment of thirty students. He announced that he would teach from the cadaver. Embarrassed by the lack of material, he found it necessary to organize groups of students to undertake expeditions of systematic body snatching. It was he, in association with other young doctors who liked to teach, who were responsible for chartering the Medical College of Virginia, in Richmond (Blanton, '42).

The Winchester Medical College, located in Winchester, Virginia, now extinct, merits some mention, because of an episode which occurred there. It was chartered in 1826 and was closed in 1829, but reopened in 1850 and survived until 1861. During the latter period, it was able to obtain an ample supply of cadavers by dint of furtive activity and much hard work. The professor of anatomy, together with his students, frequently drove out to the cemeteries and dug all night to get enough subjects.

A number of students at this school became involved in an incident at Harper's Ferry at the time John Brown, the abolitionist, was there with his forces, attacking the federal arsenal. This was in October of 1859. The young medics attracted by the excitement, went to Harper's Ferry by train from Winchester. They alighted before it reached the depot and proceeded toward the scene of activity; they soon came across a dead body, which had been shot in the umbilicus, lying on the bank of a river. Conditioned to be on a constant search for anatomical material, they obtained a box, packed the subject and shipped it back to the medical college at Winchester. After it arrived there, papers were found on the body which proved it to be Owen Brown, the son of John Brown. The cadaver was prepared for dissection and used for teaching purposes. McGuire ('38) states that the specimen was shipped back north again in 1862, by General Banks, of the Federal Army. This military man entered Winchester in 
March of 1862 and ordered the medical building burned, regarded by McGuire as an act of hate and passion. If this tale is true, it means that the dissected body of Owen Brown must have been preserved in some way from October of 1859 to March of 1862, which seems rather unlikely. 


\section{[XIX]}

\section{HUMAN DISSECTION IN THE EAST NORTH GENTRAL STATES}

$\mathrm{T}$

hese states comprise Ohio, Indiana, Illinois, Michigan and Wisconsin. A total of 135 medical schools have existed in this region at one time or another of which thirteen now remain. Most of the factual knowledge available, in respect to human dissection, revolves around the states of Ohio and Illinois.

\section{A. Dissection in Ohio-A.D. 1810 to 1880}

Of the forty-two medical schools which have been established in the State of Ohio, three now survive. Considerable information has been published on the status of human dissection there particularly by Edwards ('50-'51, ' 51, ' 54 ).

Body snatching was recognized early by the people of certain regions in Ohio. In 1811, before the organizing of medical schools, a robbed grave was discovered during the winter in the city of Zanesville. A wheelbarrow was the vehicle used to transport the body, which left a track in the snow. By following it, searchers were led to a hotel which served as a residence for three medical apprentices. The mob broke into the building and found the stolen body placed behind some logs in the basement. A shambles was made of the hotel.

The state legislature tried to do something about resurrection in 1831 when it passed a law subjecting those found guilty of body snatching to a fine up to $\$ 1,000$ or thirty days imprisonment. This was amended in 1839, making the sentence one to three years in the penitentiary. It, apparently, did not stop the practice since an angry crowd gathered at the Worthington Medical College, organized in 1831 for the purpose of protesting recent grave robberies carried on by the school. So emotionally aroused were 
the people, that they threatened to destroy the buildings. The officials felt forced to close the college and soon moved it to Cincinnati. After changing its name several times, it dissolved in 1939.

Following this (1840), a bill was introduced into the legislature to legalize dissection but it was postponed indefinitely.

Under somewhat similar circumstances, as had occurred at Worthington, Willoughby Medical College was forced to move to Columbus in 1847; it is now Ohio State University Medical School.

On October 25, 1845, the citizens of Painesville, Ohio put their feelings in writing, challenging the need of medical schools, in the form of two resolutions, the second of which read as follows: "Resolved: That the depredation of morals consequent upon the disinterment of bodies, and the annihilation of the better feelings and sentiments that usually follow a long familiarity with the horrid dissecting-room, renders it no doubtful question, whether medical colleges are not productive of more mischief than benefit to the country" (Edwards, '51).

In Cincinnati in 1852, it took only human skeletons to precipitate a mob attack. These were discovered in a small shack, on Walnut Hill Road, bearing the sign of "Chemical Laboratory." When confronted, the owner of the place and his partner fled the scene in horse and buggy. On their way toward the city center, they were arrested for fast driving. This permitted the pursuing crowd to overtake them. Both the officers who now served as defenders, and the pair were badly beaten. Nevertheless, the authorities were able to reach the prison where the suspected men were safely ensconced. They were soon freed when it was learned that the bodies, from which the skeletons had been prepared for scientific purposes, had been legally obtained.

Cincinnati was the habitat of another interesting professional resurrectionist, William Cunningham, who was born in Ireland in 1807; he was known in the trade as "Old Cunny." He was also called "The Ghoul" and "Old Dead Man." According to Edwards ('54), he was described by the parents of the illbehaved children as a bogeyman. As a part-time vocation, he worked at the game of body snatching between 1855 and 1871 .

In many respects, he was the counterpart of the lowest type 
of resurrectionist flourishing in Great Britain earlier in the same century. Physically, he was a big, rawboned muscular man with a protruding lower jaw and he possessed an unconquerable thirst for liquor of any kind.

One of his methods of transporting a body was to place it, dressed in old clothes, on the seat beside him in his buggy. Throughout the journey to the medical school, the subject was treated as if it were alive and drunk. With people within hearing distance, he would talk to the corpse as follows: "Sit up! This is the last time I am going to take you home when you get drunk. The idea of a man with a family disgracing himself in this way" (Edwards, '54).

On one occasion, while on their way to perform some resurrecting, Cunny and his two helpers stopped at a saloon in Carthage for liquor refreshments. It was near midnight and their behavior aroused the suspicions of the patrons sufficiently so that they organized a posse to follow them. They were stalked to a cemetery and while in the process of digging for two subjects, shots were fired at them. The only one who stood his ground was Cunny and he refused to elevate his hands when so ordered. One of the members of the posse, with gun aimed at him, pulled the trigger, but it failed to go off. On hearing the click, Cunny decided he had enough and gave up, pleading for his life. This was granted and they headed in the direction of Carthage; on the way, the captive, Cunny, offered to buy the others a drink at a tavern they were passing, which was accepted with alacrity. After they had consumed several, Cunny was released, on the condition that he return straightaway to Cincinnati. The grave robber, however, headed back to the scene of his previous activities, found that his assistants had removed the pair of cadavers and put them in sacks; thus, they were ready for transportation.

At another time, the same body snatchers were apprehended near Hartley, Ohio, with two subjects in their possession. They were arrested; the specimens were taken to a funeral establishment to be identified, if possible. The three culprits were released on bail, the succeeding morning. That afternoon, two men of unassuming appearance, arrived at the undertaker's parlor, and said to an assistant, who was there alone, that they were author- 
ized to remove the pair of bodies to the coroner's office, where an inquest would be held. When the owner returned and learned of the news, the coroner was contacted. He was informed by this individual that the subjects had not been delivered to his office nor had he sent for them. Because the subjects in question could not be produced as evidence, the charge against the resurrectionists was dropped and their bail money returned.

Cunny's activities in this field ranged beyond the confines of Cincinnati as he resorted to shipping bodies across the state lines. The Cincinnati Daily Gazette on January 20, 1870, contained an item reporting that he had deposited at the United States express office, a box labeled "glass with care, C.O.D.," which was addressed to Dr. M. P. Hayden, Leavenworth, Kansas." On seeing who the shipper was, the agents became suspicious, opened the container, discovered the body of a Negress, which they thought was definitely "prepared for the dissecting knife" since it was enclosed in a giveaway sack. They refused to ship the parcel and it was returned to Cunningham (Edwards, '54).

Medical students of those days apparently played jokes on Cunny when they could get away with it, which was not often. To get revenge on one group, he resurrected the body of a smallpox victim, delivered it to their school and was satisfied to learn that several of them contracted the disease.

Near the end of Cunny's resurrecting activities, when he was sixty-three years of age, he was arrested for being drunk and firing a huge revolver on Central Avenue in Cincinnati (January 13, 1870). At that time, and the following year, he was doing a lucrative business. This was possible both because of the local demand and the ease of obtaining subjects. It was a simple matter to get in cemetery grounds. A newspaper of the day commented how men of extremely low social standing were buying fine homes and driving in expensive carriages. Edwards ('54) states that presumably the article was referring particularly to "Old Cunny."

The career of this character came to an end late in 1871 and the Cincinnati Daily Enquirer, of August 31st, featured it under the title, "The Champion Resurrectionist Caught" (Edwards, '54). At 1:00 A.M., in the morning, two officers, on patrol in Cin- 
cinnati, were attracted to a scene, where an old man, in a horse and buggy, was being chased down the street, followed by a crowd of men, who were shouting and trying to catch him. When the policemen called for him to stop, the man, who was "Old Cunny," responded by whipping his horse, who was lame and tired from drawing a heavy load. After sprinting, a patrolman was able to grab the bridle of the animal and bring it to a halt; the other took care of the driver. Two sacks, containing bodies, were found in the wagon; one was that of a mature man, the other a young boy ten to twelve years of age.

Cunny was imprisoned and the two subjects turned over to the coroner. On posting $\$ 300$ bail, he was released but later, in September, was indicted on five counts. There is no record of his subsequent history with the law. On October 23, 1871, he became a patient in the Cincinnati Hospital and died ten days later. This wasn't actually the end of "Old Cunny," because his widow turned his body over to the Medical College of Ohio (now the University of Cincinnati College of Medicine) and received the unspectacular sum of $\$ 5$ for it. His skeleton rests in the museum of that institution (Edwards, '54).

Baldwin ('36) cites an incident which occurred while he was teaching anatomy at Columbus Medical College during the last quarter of the 19th Century. A mulatto, more white than Negro, had been lynched by an angry mob because he was suspected of raping a white woman. The body was turned over to the school; when it arrived in the anatomical laboratory, it made quite an impression because of its remarkable muscular development. An agreement was immediately made with the students assigned to dissect it, that the college would recompense them for turning the skeletal parts over to them; directions were given to the dissectors as to how the bones should be preserved. Later, these parts were sent to a reliable firm in the east. Impressed by the magnificence of the osseous parts, they wrote back that they would like to give it special treatment rather than employ the ordinary boiling process for cleansing. Baldwin replied, giving them permission to treat the matter as they saw best. When the articulated skeleton was returned, it was judged by all to be a remarkable specimen and was used for many years in teaching anatomy. 
The same author states that in the early days of grave robbing, it was generally looked upon as a sort of religious offense rather than a crime. Legally, it was nothing more than a misdemeanor, which was difficult to prove; therefore, it was punished by either a short jail sentence or a minimal fine. Medical students were usually quite glad to accompany a demonstrator, or any procurer of bodies, and looked upon such a venture as a mere lark. There was a feeling among the profession that this type of stealing should be limited to the subjects which were those of executed criminals or of the pauper type. However, the dearth of material led to an utter disregard of this idea.

A body snatching episode of paramount significance, occurred in the state of Ohio, in the year of 1878. It involved a member of a distinguished family and was responsible for changes in the anatomical laws of several states. On May 26, 1878, John Scott Harrison, U. S. Senator passed away and was buried three days later in Congress Green Cemetery, located in North Bend, Ohio. He was the son of William H. Harrison, who served as President of the United States for one month in 1841, and was the father of Benjamin Harrison who became President in 1888. The day after John Scott Harrison was put in his grave, one of his sons and a nephew went to Cincinnati in search of the body of one William Devin, a young friend of the family; they had information that it had been stolen from its grave and transported to that city. In their investigation, they canvassed the Medical College of Ohio (University of Cincinnati) without finding any evidence of the subject they were looking for and were about to abandon the project. At that moment, a body was raised up into the dissecting-room by means of a hoist. Its head and shoulders were covered with a cloth. When the hood was removed, both young men recognized it as being the body of John Scott Harrison, in spite of the fact that his patriarchal beard had been cut off below the chin. The commotion that followed can easily be imagined. The deceased's son, Benjamin, arrived on the premises the following day and he endeavored to arouse public sentiment, at which he was successful. The newspapers of the city and, in fact, the whole nation contributed their share in arousing the emotions of the populace. 
Most of the members of the anatomical departments throughout the state met to discuss this unusual case and it was not long after that a delegation representing them met with a committee of the state legislature. It was decided that the medical schools sorely needed dissecting-material and that adequate facilities for obtaining it did not exist. A bill was introduced which was hurriedly enacted into law (1879). The act of body snatching became a penitentiary offense, with a heavy fine attached; before this it was simply a misdemeanor. This was instrumental in providing a more plentiful supply at the time.

In the late fall of 1878 , a body was stolen from the cemetery belonging to the Columbus Hospital, by several students from Columbus Medical College. This site had long been a common ground for resurrectionists. While transporting it from the wagon into the basement of the school, a policeman who was on beat, accosted and interrogated them. The "gentlemen" body snatchers were frank with their answers since they thought that everyone understood the prevailing custom. The officer decided he had a case against them and they were arrested.

On learning of the situation, a college official put the body, that of a young girl, in a cheap coffin, and deposited it in the potter's field located in the south end of the city. Two men from the hospital, Baldwin and Bailey, drove to the cemetery and found the subject in a small, frame tool house. The lid of the box was opened and it came off with an explosive force. The coffin was full of flies and the sight filled the pair with horror. The girl's face was distorted, her eyes were wide open and maggots were rolling out of her mouth. The corpse was promptly returned to its former resting place. Later, the policeman was discharged for his stupidity (Baldwin, '36).

Also, in 1878, Dr. Erwin Heyl, a young Columbus physician, removed four subjects from a Zanesville cemetery, but was caught with them in his carriage. He was brought to court and his trial proved to be a mere formality. The judge sentenced him to one year in jail, three months for each body, together with a fine of $\$ 1,000$. The doctor had little money in his possession but his wife had some which she used in his behalf. A few months later, when feelings had died down somewhat, she solicited a 
pardon from Governor Richard M. Bishop, who was sympathetic and granted one eliminating the jail sentence. However, the citizens of the community were against the decision and the sheriff, who was running for re-election, and wanted to stand in good with the voters, refused twice to give up the prisoner on the grounds that the governor's secretary had misspelled the name. When it was considered for the third time, the appellation was written with great care and the release also included the exclusion of the fine. As a sidelight item, the sheriff was not re-elected.

The attitude of the press towards medical colleges was revealed by the following item in an Ohio newspaper, written on November 18, 1878 (Edwards, '51):

"In all parts of the country are established medical colleges. In fact, a second class city is not thought to be complete unless a medical college is established within its limits. Here collect ignorant professors to lecture to still more ignorant pupils. Surgery! Not one in a hundred knows anything whatever about surgery. But bodies must be secured to make the brainless youth believe the brainless professors know something about surgery. These brainless youths, who will soon be turned out to prey, like a set of harpies, upon the people, must be taught, however, to make sport over the remains of some body, which has been stolen from where relatives and friends have tenderly placed it. It is a most disgraceful thing that the people are preyed upon by ignorant blockheads who sail under the name of physicians."

In 1880 , the law was amended so that a more abundant supply of cadavers became available and resurrection was outlawed completely. On February 19, 1881, all unclaimed bodies which had to be buried at the expense of the town became legally available for anatomical dissection.

\section{B. Dissection in Illinois-A.D. 1850 to 1900}

Forty-four medical schools have existed in the state of Illinois, at one time or another, and only five survive. There is evidence that grave robbing was an established practice as early as the middle of the 19th Century. 
One of the first incidents of significance involved a Dr. Prince, who taught anatomy at the Medical Department of Illinois College, located in Jacksonville in the east-central part of the state, not far from Springfield. This institution had only a five year existence principally because of difficulty in acquiring an adequate supply of subjects. Dr. Prince refused to teach anatomy without offering its practical aspects. Nightly excursions were made to the cemeteries by the demonstrator and students. The professor was blamed for certain unexplained developments. An irate mob approached the school and accused him and his students of exhuming the body of George Joseph Duncan. With the help of some influential persons, the wrath of the rioters was assuaged and injury averted. This event, which took place in 1848, was instrumental in hastening the closing of the school.

About this same time, 1849, Franklin Medical College, located in St. Charles, about forty miles west of Chicago, became involved in a more serious affair. This school also had a short survival time. A discovery was made that a fresh grave in the neighboring town of Sycamore had been robbed of its inhabitant. The blame fell on the medical students of St. Charles. An armed mob formed, proceeded to that city and stopped at the home of Dr. George W. Richards, professor of anatomy, demanding that the body in question be turned over to them. The teacher's family fled by climbing the stone wall in the rear of the house, but he held his ground. He did his best to convince the angry crowd that the subject in question was not in his residence. When they insisted on entrance, he closed the door, locked it and braced himself against it. One of the members of the gang shot through the door and the bullet passed through the upper part of Richard's arm, severing a part of his brachial plexus. Thereafter, he was permanently paralyzed in this part of the body. In this fracas, the student who was credited with securing the body, was injured and died of his wounds (Anson, '56; Edwards, '51).

After repeated outrages of this nature, in the year of 1885 the state legislature passed an anatomical law for the protection of the people (Weaver, '23-'25).

At the turn of the century, there was little general outspoken opposition to human dissection, in Illinois, but a fanatical 
leader of a religious sect in Zion City, a suburb of Chicago, created a sensation by claiming that both Michelangelo and da Vinci practiced dissection on living humans. This zealot was opposed to all medical treatment and all science. He taught that the world was flat. He wrote: "I will tell the story of a dissecting-room where the first touch of the lancet made the supposed corpse rise from her long trance; and as the sight burst upon her of those butchering students with their garments stained with blood, standing around her, all aghast with fear, holding their knives in their hands, she realized the horrible fact that she had been carried there for dissection, and she instantly died from the shock and the wounds inflicted by their knives. . . . The very best man in the profession will tell you that nineteen-twentieths of the dissections are unnecessary. But they please the devils who are preparing the doctors, and accustom the youths to the atmosphere of profanity as they hear the filthy and unclean remarks which are made as they stand over the dead bodies and handle the sacred secrecies of humanity and laugh with diabolical glee over the consequences of a poor woman's fall or a degraded youth's syphilitic body. I tell you this, that pollution, damnation, and hell are holding high carnival there, and a young man who escapes from that without life-long injury is only one in a large number" (Haggard, '29).

\section{Dissection in Indiana-A.D. 1880 to 1890}

The state of Indiana has had twenty-seven medical schools during its history of which one survives. Although it passed an anatomical law in 1879, as a result of the resurrection of John Scott Harrison, in the neighboring state of Ohio, body snatching was still in vogue at the turn of the century. In this year, twenty-five persons were indicted for such violation and these included several physicians, identified with local medical colleges. Fifteen empty graves were found in the vicinity of Indianapolis and several bodies were traced to the medical schools. An editorial in the Medical Standard, 1902, stated that it was estimated that a gang apparently led by a number of Negroes, had resurrected approximately 100 bodies. At the time of the article, the real responsibility for the affair had not been traced to its source, 
The people of the community were very much aroused on learning of this development and were backing the resources of the law to catch the offenders (Editorial, '02).

The editor felt that grave robbing was regarded with special horror and detestation and that the medical profession must look upon it without a measure of satisfaction and with disapproval. The practice was doubtless excusable and necessary a century before when the law made no provision for anatomical material so essential in the teaching of medicine. He claimed there was no reason for it in 1902 and he could only conceive of the medical colleges participating in such a sad business on the theory that the Indiana law was totally inadequate to fulfill the needs of the medical students. Until there was more evidence, he viewed with suspicion any effort to fix the guilt upon his confreres in Indianapolis.

D. Dissection in Michigan-A.D. 1850 to 1870

The state of Michigan has had sixteen medical schools throughout its history, of which two survive. The University of Michigan was organized in 1850 and as early as 1866 , it had 525 students enrolled in its medical courses, which made it the largest extant in America at that time. It was staffed by distinguished teachers. The anatomical classes were so large that bodies had to be shipped in from the outside. This was done by means of innocent looking barrels labeled "John Smith, University of Michigan, Ann Arbor, Michigan." 'Bodies were put in these with head and feet on the bottom, legs flexed and breech uppermost. Most were white, some were Negroes and a very few were Asiatic. Only the professor of anatomy and demonstrator knew the source of these specimens (Johnson, '23). 


\section{$[\mathrm{XX}]$}

\section{STATUS OF HUMAN DISSECTION IN THE UNITED STATES-A.D. 1900 to 1958}

Anatomical teaching in the United States has probably been
subject to more alterations during the past half-century than has
that in the medical schools of any other nation. These changes
have involved the subject of gross anatomy, which is dependent
almost entirely, or at least basically, upon an adequate supply
of suitable cadavers. In considering the evolution of this specialty
in American medicine, the following factors can be enumerated:

1. The impact of standardizing agencies.

2. The number of anatomical departments and medical students existing from year to year.

3. The demand, from various sources, for cadavers (medical, dental, embalmers and others).

4. A consideration of a rapidly expanding population.

5. The status of anatomical laws.

6. The growth of new subjects in the medical curriculum.

7. The general attitude of the public towards dissection.

In order to draw comparisons, a picture of the status of anatomical teaching in this country, shortly before 1900, is briefly presented. With a few notable exceptions, the medical schools which existed were of the fly-by-night variety. Classes were held in rudimentary buildings possessing the poorest of laboratories. Any young physician could route out statutes for a proposed medical school in the form of a stock corporation. All that was necessary, was to elect a council of administration, request state authorities to inscribe a new creation in official registers and issue a prospectus for publication in medical periodicals, with a list of professors, who the day before might have been simple and unknown physicians. Diplomas were granted at the end of two years and 
graduates were allowed to practice in the state where their medical school was located. Between 1776-1810, seven new medical schools were chartered; between 1810-1840, twenty-six; in the interval 1840-1875, forty-seven; and seventy-nine between 1875 and 1901 . This sums up to a total of 159 .

According to Bardeen ('05), the standards fell as the schools multiplied and as little medical education as possible was sold at the highest possible rate. As the competition was keen, they were reluctant to add anything new, which might frighten students away. There were, however, a few first-rate private institutions affiliated with universities; also state controlled ones were beginning to be strongly organized and staffed.

Prior to and for a short period after the beginning of the present century, practically all of the teachers were part time. They consisted of a professor, who occupied the chair, and one or more demonstrators who were in charge of the dissectinglaboratory. The former presented lectures only. Most were surgeons, the heads usually having a practice whereas the others were in the process of establishing one. Together, they spent between 800 and 900 hours, almost entirely on gross anatomy. In general, the teachers used their positions as stepping stones to their practice, which enhanced the opinion that anatomy constitutes the handmaid of surgery. They taught authoritatively with most of their energies being devoted to Gray's Anatomy and to the neglect of microscopy and research. Main stress was put on the quiz. Because they did not consider anatomy as a science, they made few contributions to the field. Between 1872-1881, there were thirty investigations by American anatomists reported in Schwalkes Jahresberichte, 1 per cent of the total, and in the interval 1892-1901, there were nearly 400 among 10,000 international contributions, about 4 per cent of all listed (Bardeen, '05; Mall, '06).

Some of the important medical and private agencies which have both analyzed and influenced medical schools in reform in anatomy at various times since 1900 are the following:

1. The Council on Medical Education of the American Medical Association which began to classify medical schools as early as 1906 on the basis as to how medical students fared in State 
Board examinations, including anatomy (Report of Council on Medical Education, '06).

2. A sub-committee of anatomists, appointed by the Association of American Medical Colleges to make recommendations for reform in anatomy (Bardeen, '09).

3. The Carnegie Foundation for the Advancement of Teaching which published the well-known Flexner report on Medical Education in the United States and Canada, in 1910.

4. The Commission on Medical Education which was appointed by the Association of American Medical Colleges and which reported their conclusions in 1932 in a volume entitled, Final Reports of the Commission on Medical Education.

5. The Weiskotten report on Medical Education in the United States, published in 1940 by the Council on Medical Education of the American Medical Association.

6. National, State and Specialty Boards of Examiners.

7. The Commonwealth Fund which published Medical Education in the Changing Order (Allen, '46) and Trends in Medical Education (Atchley, '49) and the John and Mary Markle and Rockefeller Foundations which sponsored meetings of the American Surgical and Dental Associations for the purpose of suggesting improvements in undergraduate medical education ('50).

It may be of interest to mention specific opinions and standards regarding anatomy by some of the above agencies which have most influenced the subject since 1900. In 1906, the Council on Medical Education of the American Medical Association divided the medical schools of the United States into four classes depending upon the percentage of student failures in State Board Medical Examinations in anatomy. The average number was high and the members believed the first step in raising the general standards of medical education was by abolishing all the medical schools which were then conducted for profit.

Bardeen ('05) reported the recommendations of a sub-committee of anatomists appointed by the American Medical Association to study teaching in anatomy as follows: They felt that anatomy was in bad repute. The members suggested that all teachers of this subject should be full-time, have a thorough professional training in the various branches of anatomy, have demon- 
strated ability in applied teaching and research and that there should ideally be one teacher for every fifteen to twenty students. The time should be decreased from an average of $800-900$ to 630 hours where the course of study had a total of 4,100 hours. They also proposed that histology, embryology and neuroanatomy be given consideration as major subjects.

Flexner, in his well-known 1910 report, stated that anatomy, the oldest of the laboratory sciences, logically comes first in the curriculum because it is so fundamental. He believed that histology, embryology, physiology and pathology had given it back its youth making it once more a green and flourishing science. According to him, the anatomist was carrying a steadily increasing load; the surgeons were embarking on hitherto unknown ventures, the physical indications involving most delicate structures and discriminations were important to the clinicians and the preclinical teachers leaned on him. The student, he felt, must gain a picture of the body as a whole, of its parts taken severally in their relations. He stated that the teacher had two choices: stick to teaching what he thought was useful and practical or approach the subject from the broad scientific viewpoint. There was no doubt in Flexner's mind that the latter road was the better to follow; he reported rather deplorable conditions existing in the anatomical departments of the medical schools functioning in 1909.

The Commission on Medical Education ('32) reported that anatomy was overcrowded; that it is closely related to biology on the one hand and clinical medicine on the other; that students studying it should visualize structures in the living, healthy individual; that minute details should not be taught in the undergraduate courses but rather in the specialties so that the amount of time devoted to it in the first year could be reduced; and finally, provisions should be made at intervals throughout the four year medical course for review and extension of anatomical knowledge. This group felt that the instruction could be improved by using such instruments as the ophthalmoscope, otoscope, x-ray and others as well as clinical illustrations. In the opinion of its members, it was not necessary for anatomy to have profound clinical and practical application in the undergraduate course. 
According to the Weiskotten report of 1940, no subject in medical education can be considered to be more basic than anatomy; therefore, it should serve as the underlying foundation for the students, training and experience. It states there is a great need for more capable and scientific leadership for the students of anatomy. One of the first essentials for a professor of anatomy is that he have an M.D. but this might mean nothing as some of the outstanding teachers in the country are without it. This group of educators felt that anatomical departments need more financial support, that standards should not be uniform and that the teaching should deal with fundamental principles rather than course content, clock-hours or methods. It also felt that anatomical or other research tends to create a favorable atmosphere and could be one of the most inspirational features in a department.

Since medical graduates must pass either a State or National Board Examination in order to obtain a license to practice, the type and nature of the questions given in anatomy will be of some significance in determining standards. Some schools, for instance, require all of their students to pass the National Boards before they confer the M.D. degree. Clements ('39), in his survey, stated that the Boards refer to a maze of anatomical detail, that 78.4 per cent of the questions require descriptive answers and that 79 per cent were on gross structure. He concluded that a broad knowledge of the subject is necessary to successfully cope with the Board exams. Whippel ('43) reported that out of 991 candidates examined by the American Board of Surgery, 175 failed in anatomy and he felt that many are either poorly trained, have forgotten the subject or that they are not instructed in the relative importance of certain structures. In the same article, J. S. Rodman, in the discussion, mentioned that the members of the Board of Surgery thought that anatomy was still the most important fundamental subject in the basic training of surgeons. At the time of these publications, the essay type of examination was in vogue. The recent shift to the objective has probably not altered the necessity for the student to know anatomical detail.

Within the past decade, there have been some relatively radical criticisms by non-anatomists regarding the status of anatomy in the medical curriculum. Gregg ('42) believes that more time 
should be devoted to teaching what is known of human individuality, growth, the aging process, the endocrines and heredity at the expense of gross dissection, which he suggests should be correspondingly reduced. The incoming students should be taught to be thorough and observe accurately and also where and how to find the anatomical facts they need to know. Dock ('42) states that anatomy has never been thought of as a cultural subject, that its present teachers have been mostly students of biology and physiology who have no practical interest in the subject, that human dissection is far from being an ideal starting point for the medical student, and that histology is of value only in connection with the physiological activity of cells and gross anatomy with the functions of the body. He feels that anatomy and physiology should be combined into one department and that histology and gross anatomical demonstration should introduce each field in physiology. The dissection should be placed in the curriculum where it would be most valuable; it should be completed before the students graduate and should be taught by young internists, radiologists and surgeons. Further views are expressed by this writer.

Using as an example the methods employed in teaching biology to college students, Johnson ('45) advocates collaboration of teachers in medical schools for the purpose of presenting an integrated picture of the human body in health and disease. In this scheme, anatomy would be abolished as a course along with physiology and pathology and would be taught over a period of five quarters by members of a committee chosen to teach conjoint courses during the first and second years. In all the basic sciences, appropriate clinical material should be presented.

Carpenter ("47) believes it is no longer justifiable to devote long hours to detailed study of anatomy and other medical subjects because the extent of knowledge today prohibits memorizing. The important thing is to know where the essential facts are recorded. He groups the various courses in anatomy in a division of "structure" which includes pathology and radiology. An elevenweeks course in gross anatomy is recommended which is considered to be a guide to understanding morphology and its relation to health and disease. The anatomist should teach throughout 
the medical course in an integrated system. He states that the plan requires a full staff, that the teaching duties are continuous and that the whole program offers some handicap to research.

Some of the latest activities in medical education center around programs advocated and supported by several of the private foundations. Allen ('46) believes that anatomists have reached a point in studying the finer morphology of the human body where further progress depends largely on correlated studies in function. Medical, rather than the individual sciences, should be taught and he feels that the demarcation between the various preclinical departments may entirely disappear. Atchley ('49) advocates that teaching groups for the first two years be organized in terms of dynamic units and that they use the systemic or vertical approach in studying the human body.

The Committee appointed by the American Surgical Association, which functioned under the auspices of the Markle and Rockefeller Foundations ('50) reports that from the surgical standpoint there has been a shifting emphasis from anatomy and the techniques of surgery to immunology and pathological physiology. It believes that cadaver anatomy should be abolished as a historic oddity of teaching and that gross anatomy is best taught at the autopsy table primarily because the specimens are fresher. It favors a gradual evolution in integrated instruction with the surgeons and internists assuming a paramount role. The tutorial method is recommended as the one of choice, with small groups of pupils, an approach, which they emphasize puts the burden on student learning. There have been numerous other important articles on the topic of anatomy which eulogistically defend the status quo in teaching the subject.

The above review shows to some extent the evolution of thinking on the significance of anatomy, particularly gross, in the medical curriculum by certain influential groups interested in medical education. In the light of the various viewpoints above, the question arises as to what changes have taken place in the field since 1900 which are peculiar to United States medical schools.

The period between 1900 and 1958 has been marked first of all by the disappearance of all anatomy departments which 
were originally designed for private gain and which were considered to be such a bane by the American Medical Association back in 1904. The number of medical schools have been reduced by about one-half, from 159 in 1901 to 81 in 1958 . Between 1901 and 1940, there were eighty-two medical schools which closed their doors because of inability to meet the new standards imposed on them. Recently, there has been a trend toward the organization of new medical schools.

Further, there has been a shortening of the hours devoted to gross anatomy from about 900 (Bardeen, '08-'09) to an average of 330 (Turner, '56). This has been due to the growth of histology, neuroanatomy, embryology and other subjects in the basic sciences.

In spite of a decrease in the medical schools existing in the United States from 159 to 81, during the past half-century, the number of total freshman students enrolled has more than doubled whereas the average per class has nearly tripled. With a total of 7,576 such pupils in the eighty-one approved medical schools of the United States, in 1955, this would mean that about 3,800 suitable dissecting cadavers would be required for the ideal arrangement of two working on one subject and half that number for four on one. Some schools, interested in teaching anatomy for dentists, embalmers or postgraduates, would need perhaps more than double the number used for the first year medical class. These values do not take into account the fact that some cadavers, when received, are of such quality that they must be discarded. It can be estimated that a minimum of about 5,000 subjects are annually needed for an all-around, first-rate program for the teaching of practical anatomy in medical and dental institutions alone.

Probably the most important factor in the matter of obtaining an adequate supply of cadavers to fill all requirements revolves around the status of the anatomical laws in the various states which have medical and dental schools.

Jenkins ('13) made a study of the legal status of dissection in 1913 by sending out a questionnaire to the medical schools in the United States. He stated that only recently (prior to 1913) had any worthwhile anatomical laws been enacted. Before these, body snatching was common, the demands for bodies grew, the 
competition became keener, there was connivance with resurrectionists, the cost increased, crimes of a grave nature occurred and anatomical teachers came into disrepute. His statistics show that of fifty-five medical schools reporting from thirty-six states, forty-one had an adequate supply, five had barely enough, eight had an insufficient number and only one had an excessive quantity; thirty-four were receiving good material.

Even though the anatomical laws, had been improved, Jenkins ('13) found a wide variation in their content. In general, most cadavers were received from almshouses. A few states permitted only the use of bodies of criminals dying in penal institutions. In the others, the unclaimed dead were made available, sometimes with reservations as follows: when they had to be buried at public expense, when claimed by relatives or friends, when they had served in a branch of the military services and when requests had been made not to have their bodies assigned to medical schools.

Woodburne and Gardner ('54) have reviewed the status of anatomical material and laws in the United States by taking a poll of anatomists. Their study reveals that most schools now meet teaching requirements but that the majority of departments report that such a supply is minimally adequate. In some, an unsatisfactory situation exists. The factors responsible for variations in distribution, according to these authors, are the following:

1. Density of population.

2. Prosperity of the economic condition.

3. Increasing social welfare burials.

4. Conflicting social welfare and old-age assistance legislation.

5. Burial insurance.

6. Increased post-mortem examinations by pathologists.

7. Laws which are so free regarding claimants and exemptions that they give low priority to anatomical teaching.

The medical schools, which are located in areas of dense population, in general, fare much better, even though several of the largest are drawing from the same source. By contrast, those 
situated in less crowded regions, have encountered more serious problems. Some of the institutions in the latter category, may be placed close to thickly populated centers in an adjacent state, but are precluded from taking advantage of it by the terms of their own state laws.

In respect to anatomical statutes, Woodburne and Gardner ('54) found little uniformity in the state laws. They suggest federal reforms as follows: the right to will ones body to a professional school regardless of difficulties with the rest of the will; provisions should be made in all states, for the disposal of dissected remains; anatomical boards should be given the authority to control autopsies; a reconsideration should be given to the importance of geographical limits and state lines and the costs should be shared among the schools which utilize bodies.

In a special feature article in the Bulletin of Medical Research ('55) the question of body shortages has been further discussed. According to it, there is a national concern about the future supply. There are eight schools where a 4:1 studentcavader ratio can no longer be maintained. One school was assigning eight students to a subject. There is a real problem in Washington, D.C. The article stated that about 5,000 bodies are needed per year in the United States, about one-third of one per cent of those dying annually.

It further reported that in thirty-one schools there has been a decrease in the number obtained; in thirty-five, it is the same as before and in eleven it has increased. Florida, which has recently established two new schools, has encountered no difficulties in its cadaver supply. In twenty-eight months, it had obtained 138 and had 75 willed bequests on file. The writer suggests that sound policies be formulated for getting material: improving the laws, which are not always obeyed to the letter; enlisting the help of civic and religious groups; promoting good public relations; establishing a unified program; and bringing the question into public view.

Overholser ("56) states that cadaver supply has become a serious problem in the Missouri medical schools, although the state has an anatomical board and it is necessary for pathologists to obtain permission from it to perform autopsies. The law, how- 
ever, in respect to post-mortems has been largely ignored; he believes that many of these are unnecessary and that this part of the legislation should be upheld. Many subjects are buried there at the expense of religious and charitable organizations. Recently, a provision was made in the statute that bodies can be willed for use and this trend should be encouraged. He has found that the supply of the unclaimed varies with the economic conditions, that more are available during times of unemployment. There may be fewer in the future due to social security, pensions, death benefits and the like.

At the Teaching Institute in Anatomy and Anthropology, held at Swampscott, Massachusetts, in 1955, it was brought out that cadaver supply is a perennial problem; that 13 per cent of the schools have shortages for basic anatomical teaching; that one-third do not have enough for upper classmen or postgraduate courses. The methods suggested which might be utilized to compensate for scarcity were the following: more students to a cadaver and the use of preparations, slides, models, material from amputations and movies. Possible ways to increase the supply consisted of such considerations as appealing to welfare agencies, hospital superintendents, physicians, and medical students; revamping the laws, legalizing the bequeathing of bodies; decreasing the number of autopsies and cultivating public interest. It was unanimously decided that teaching without human dissection is not an acceptable standard in medical education (Report of Third Teaching Institute, 1956).

One aspect of the problem which has not been mentioned in the whole question, is that of the role of undertakers. Meyer ('30) notes this in an article published in 1930. The author declares that, in the state of California, funeral directors vied for bodies of the unclaimed because if not buried by relatives, they stood to make a good profit. Some actually trafficked in dead bodies.

It was Meyer's opinion that it was "not the people at large who oppose anatomists having bodies of unclaimed dead, but a few financially interested individuals who rely for protection against exposure upon the possibility of taking advantage of public ignorance, sentiment and belief." 
In terms of balance, this is probably the clue to the future, that it is really the people who have to weigh the merits of human dissection, the value of its long practice in the field of medical education, against their deep-seated religious beliefs, which are natural and to which they have been conditioned throughout their lifetimes.

There is evidence that more and more people are willing their bodies to medical schools for the promotion of anatomical science and some institutions have carried their problem to the masses with success, notably the University of California in Los Angeles. Recently, they had over 300 bequests on file (Special feature article, '55). 


\section{$[\mathrm{XXI}]$}

\section{CHRONOLOGICAL HIGHLIGHTS ON HUMAN DISSECTION}

\section{$\mathrm{H}$}

uman dissection is intimately associated with the regard of the living for the dead. Along with man's beginnings and why he exists, death constitutes one of the three great mysteries of human life. Before the dawn of civilization, primitive man was undoubtedly more concerned with the significance of death than with the other two. Very early in his evolution, man compared this state to sleep and he called it the "long sleep." Terror and flight were among his first reactions to this condition. Then, he concocted the concrete idea that the dead live on as ghosts or spirits. This probably developed from the interpretations he gave to his dreams, his shadow, his image in water and other similar phenomena. It was logical for him, with his mentality, to conclude that all human bodies were tenanted by a spirit, a vital principle, responsible for all his activities. He assigned great flexibility, traveling power, transferability and even divisibility to it.

The uncivilized explained death as being due to a mystic or supernatural force. Man was always "doomed" to die by the malign influence of an enemy, usually a sorcerer or a spirit. He had two worlds, the living and the dead, where the latter remained alive in another form. A ghost, particularly that of a newly deceased, was evil-disposed and vengeful and there were a hundred ways in which it could show displeasure. Every human accident and diseased process was attributed to it. It had to be catered to because there was no way to retaliate. Contact with the departed, in any way, was dreaded. It was considered dangerous and even contagious. A dead body on the ground made it unfertile and barren. Greater horror was aroused when an individual died in an unusual manner. The longer after death, the 
more a ghost's power waned and it eventually wandered away to a spiritual afterworld, which varied according to location and tribes. Then, it was sometimes worshiped as an ancestor, especially when the individual had attained great stature during life. Fear, however, was the predominating emotion inspired by such progenitors.

The motivating factor leading to burial of the dead was fear of ghosts; the idea was to dispose of the body and demon at one stroke. Some measure of peace and security was apparently felt when a subject was buried five or six feet below the surface of the ground. Cremation was one of the earliest methods of disposing of the departed because it was judged to be the most effective way of handling both body and spirit. At one time, it threatened to become a universal practice.

Another important concept among primitives was that of reincarnation, especially that which held that a spirit could return to the human body. Under such a belief, violation of the dead was highly contraindicated.

The primitive concepts of death were naturally carried over into the early period of civilization. The new ideas advanced in some quarters were those of personal salvation and retribution in a heavenly afterlife; in other words, what an individual does in this world may be of paramount significance to him in another. Associated with this trend, was the origination of specific myths revolving around events said to have occurred during the life of certain selected gods, particularly in Egypt. The story of this development is intimately related to the genesis of ancient religions.

In ancient China, demons, ghosts, vampires and werewolves populated the country and they could do all kinds of mischief. Defense against them was by means of magic or the enlistment of gods as allies. Confucius was reticent about an afterlife; Buddha preached the doctrine of retribution.

Under Shintoism, in Japan, the people had a fear of their dead. Contact with a corpse, was automatically avoided because it made a person unclean and defiled. Such contamination might infect a whole community. 
The inhabitants of early Egypt were polytheistic and much concerned about their deceased; they early conceived the farreaching concept of immortality and a possible retribution in another world. They were the first who became bold enough to make incisions in a human corpse, which was related to the practice of mummification, but a stigma was attached to the man who made the cuts; one of the greatest fears an Egyptian embalmer had to overcome, was the mere opening of an abdomen. Thus, he employed a scapegoat to perform the act. During this interval, the precursor of the anatomist was born and some anatomical information was obtained about the human viscera. In Babylonia, the people were mortally afraid of the dead and did everything possible to avoid them.

Under Hinduism, in India, general burning of the dead was practiced for many centuries, with the exception of children and great saints.

In the time of Homer, in Greece, cremation was practiced and, for prominent personages, a great spectacle was made with huge funeral pyres and sport contests. Later, during the Golden Age, in that country, the human body began to be conceived as having two parts: soul and matter. The latter was thought of as being corrupt. In general, salvation, transmigration and an eventual return to earthly life was ascribed to the former.

Before the advent of Christianity in Rome, with polytheism in vogue, ghosts, spectres and bogeys populated the world. Even the priests were not permitted to come in contact with the dead, approach a grave, touch or name things associated with death and the nether world.

Therefore, during the period from 5000 to about 300 B.C., little anatomical knowledge prevailed. Spirits were generally thought to have an occult relationship to the body, even after death. A corpse was either preserved carefully, burned or entombed to prevent any insult to it which might embitter its ghost. Mere contact with a cadaver was sufficient to defile and pollute the person involved; any attempt at dissection or mutilation constituted a sacrilege of the greatest magnitude. One way in which anatomical knowledge was gained was by examination 
of severely injured or diseased humans or animals killed for sacrifice or food.

Before the great Alexandrian period of anatomy, which began about 300 B.C., mankind probably gave more thought to the possible location of the soul in the human body, than to anything else. The Edwin Smith Scrolls of 1600 B.C., and the Eber's Papyrus of 1550 B.C. mention certain bones, the heart and brain. Referring to the pulse, the latter stated that the pulse revealed that "the heart speaks in all the limbs." The soul was localized, at one time or another, beginning about 2300 B.C., in the following: heart, bowels, liver, diaphragm, blood, brain, head, chest, meninges and the whole body.

In the process of mummifying bodies, the Egyptians accumulated over 100 anatomical terms in the language which then prevailed; many of them were words based on mythology because every organ represented one of their gods.

The ancient Hindu text of medicine the Susruta, listed 300 bones, 90 tendons, 210 joints, 500 muscles, 70 blood vessels, 3 humors, 3 secretions and 9 sense organs as being present in the human body.

In general, it can be said that the period between 1000 and 300 B.C. was devoid of any actual human dissection for the sole purpose of studying man's structure. During this period, no qualms were felt about killing a man or satisfying vengeance on the body of an enemy after death but woe unto him who cut up a corpse for scientific purposes. Anatomy was a mixture of mystery, imagination and a few facts learned in everyday life. Magic continued to play an important part in the religious and commonplace life of the people and this applied to the dead as well as the living.

The first unequivocal human dissections were made at the Alexandrian school by Herophilus and Erasistratus, two transplanted Greeks. For the first time in the history of man, permission was given by governmental decree, to dissect privately or publicly. In all, Herophilus, working under ideal conditions, at Alexandria, may have anatomized from 200 to 600 human 
specimens, quite a feat for an anatomist in any age. Some at least were bodies of executed criminals. He has been accused of performing human vivisections but this is unfounded. He is called the "Father of Anatomy." Erasistratus likewise dissected many bodies and the pair made noteworthy anatomical discoveries. They were able to successfully articulate two human skeletons, which became widely known. This school survived between 332 B.C. and A.D. 200. Only fragments of their original writings have survived due to the fact that the great Alexandrian library was twice destroyed by fire, first by the Roman invaders and again by the Arabs.

Although Galen stands out as one of the greatest medical men of all time, he made few contributions to our knowledge of human anatomy. That he merits this distinction cannot be denied since his influence extended over a period of 1500 years. Although possessed of an untiring urge to dissect, this trait had to be sublimated to investigations on lower animals. The great weight he exerted on the medical profession stemmed from the facts that he was a prolific writer, who published all his findings and medical ideas, that he was followed by a period of scientific stagnation and that he was the only anatomical specialist of note.

Galen dissected the bodies of many animals during his lifetime, beginning at the age of fifteen. All anatomists of his time, including himself, took it for granted that animal and human bodies were fundamentally alike in their architecture. Many of the 500 published works by him on anatomy refer to the monkey. As might be expected, he made some errors, being unable to differentiate nerves and tendons, and his descriptions of blood vessels were poor. Being a sensitive individual, he marveled at the sight of the organs, at their beauty and complexity; he thought that form determines function and that nature never made anything superfluous. His belief that a divine providence was the creator of structure made him popular with Christians, Jews and Moslems. His works were widely though tardily translated into numerous languages up through the 16th Century and many physicians accepted his views as late as the 18th Century. 
After Galen, the practice of dissection appears to have been lost either because of further prejudices against it or the apathy of the physicians.

During the Middle Ages, A.D. 400-1400, anatomy made little or no progress. This period is characterized by stagnation, degeneration and actual loss of previous anatomical knowledge. 'The genesis of this status was probably the deterioration and decline of the school of medicine at Alexandria. The prevailing psychology of the people characterized by hostility, militated against the advance of the subject.

"The human body had no standing; rather, it was regarded with contempt and anatomy passed for a pagan science. It was man's soul which ranked high and saving it from hell was the priests' main function. Life was judged to be a transitory waystation between two eternities and all learning was monastic. Magic was accepted by many members of the populace and the "possessed" and "witches". came in for their share of attention. Punishing them by death became a reality of the times.

During the latter part of the Middle Ages, it was the Arabians who kept literature and science alive, by translations of older Greek and Roman works.

Between A.D. 1200 and 1350, fifteen new university centers were established in Italy and it was they who had most to do with the revival of human dissection. Frederick II, Emperor of Germany and the two Sicilies paved the way by granting permission to anatomize in A.D. 1240. One human subject was allotted to the University of Salerno every five years. Mondino da Luzzi, A.D. 1276-1326, was the first post-Alexandrian to completely dissect a human body, that of an executed criminal, in 1315. He set standards of procedure which prevailed for centuries: a barber performing the dissection, the professor reading from a high chair and a demonstrator pointing out the various structures with a rod. The sole aim was to illustrate Galen to an audience usually made up of high ranking officials and privileged civilians. Rites were performed upon the condemned before execution to atone for the deed about to be done; festivities climaxed the events. Mondino wrote an anatomical text which went through twenty- 
three editions. The first incident of resurrecting a body probably occurred during this period when four students were apprehended for stealing a body and transporting it to the University of Bologna, where Mondino taught. During the 14th Century, human dissection was also carried out at a number of other schools: Florence, Lerida, Montpellier, Naples, Prague and Venice.

It was during the Renaissance, A.D. 1350-1650, that certain pioneers dared to come to grips with the superstitions and hostilities of the populace, to make accurate observations on the structure of the human body and to report what they saw at the risk of censure and social ostracism. It was one of the most progressive periods in the history of anatomy.

During that era, factors still militating against human dissection were the following: religious belief in a soul, superstition, faith in the writings of Galen and Avicenna, repugnance of society and the lack of proper methods to preserve the body. But the practice continued to spread throughout Europe and to Great Britain. Concomitant with this, some attention was paid to the passage of laws pertaining to anatomical dissection and to the building of magnificent anatomical theatres.

Many famous painters developed programs of actual anatomical dissection especially in the early part of the Renaissance. Leonardo da Vinci, Michelangelo, Albrecht Dürer and Titian were included. As a group, their minds were untrammeled by traditional bias, they were enthusiastic and they were trained in making careful observations. They were sometimes able to obtain bodies, by sanction and help of the Church, as in the case of Michelangelo. Knowledge of muscular structure and the art of making anatomical illustrations were advanced through the efforts of these artists. During his life time, da Vinci made 779 anatomical drawings; he was of the opinion that the anatomists around him revered the human body whereas others in society were more inclined to destroy it.

Among the teachers who stood out in this changing period, can be mentioned Sylvius, Servetus and Vesalius, each having distinguishing personality traits. Sylvius, at the University of Paris, taught anatomy in the traditional fashion but saw the 
structures of the human body through the eyes of Galen, whom he idolized and glorified. When forced to admit that some of his observations were incorrect, he supplied the answer that the body had altered in its organization during 1400 years. Nevertheless, he encouraged dissection, helped to popularize it and give it renown.

Servetus, with religious leanings, became interested in the anatomy of the respiratory system because he was searching for the site of the soul. This was while he was a student at Paris. There are some who claim that he was the first to discover the pulmonary circulation of the blood. Because he believed that the idea of the union of the three divines of the Trinity was a mere phantasy, he was finally tried, imprisoned and burned at the stake in 1553 .

Probably the most important figure in the history of anatomy was Vesalius. His publication of the Fabrica in 1543 marks a turning point not only in anatomy but in the whole field of medicine. Although working at great odds to obtain suitable cadavers, he was successful in the following: neutralizing the authority of Galen, recasting the instruction of human structure; starting basic, medical research in anatomy, physiology and surgery; illustrating his dissections accurately; destroying long established tenets and making many new discoveries. He ranks among the greats of all time.

Without much doubt, the most spectacular events in the evolution of anatomy occurred in Great Britain. It was here that the road was paved for student dissection in English speaking countries, which multiplied the problems of cadaver supply, in the face of inadequate anatomical statutes. More and more young men became interested in studying medicine which necessitated more medical schools to accommodate them. Some of the latter became fly-by-night places or diploma mills. Medical standardizing agencies required that students study human anatomy. Body snatching, which had been largely conspicuous by its absence on the Continent, became the principal method of supplying subjects in the British Isles. 
This situation led to the rise of a group of low-class professional resurrectionists who took over the duty of supplying cadavers to the needy medical schools: they replaced surgeons, students and teachers in this endeavor; made up of rowdies, criminals, gravediggers and sextons whose sole aim was monetary, it did not take them long to commercialize the practice. They operated in the form of unlicensed and unwanted guilds. The peak of this movement was between 1800 and 1832 before the passage of the British Anatomy Act in 1832. It was possible for a clever gang of four or five to unearth as many as 400 bodies annually and rapidly dispose of them to the anatomical schools at a total price close to $\$ 8,000$, considerable money in those days.

Many tales have been told about individual resurrectionists but certain persons who were not strictly grave robbers supplied the main drama in the early 1800 's. Two of these, were the notorious pair of Burke and Hare. With the assistance of two female accomplices, they were able to complete sixteen murders, during an interval of eight and one-half months in Edinburgh, before they were apprehended. The victims were made up of widows, orphans, streetwalkers and imbeciles. After being apprehended and indicted, Burke was sentenced to be hung, his body exhibited in chains and publicly dissected. His hanging was witnessed by about 25,000 people on January 28, 1829 .

An unusual feature of the murders, was that all of the slain bodies reached the private anatomical laboratories of Dr. Robert Knox, one of the outstanding anatomists of his time, who thus became a central figure in the events. He was condemned pretty much on all sides, even among members of his own profession. Violent opinions were expressed through the existing means of communication and he was never able to overcome the reactions. It led gradually to his professional downfall.

Even this series of crimes, was insufficient to agitate the British legislators into final action in respect to the passage of a workable anatomy act. It required another incident, this time in London, to set the wheels effectively in motion. A young fourteen year-old boy was murdered in London on November 5, 1831, by two men, Bishop and May, and an accomplice, Williams. It was discovered and Bishop and Williams were sentenced and hung 
on December 5, 1831. The Warburton Anatomy Act, an important piece of legislation, was then hurriedly passed on August 1, 1832. It sounded the death knell for body snatching in the British Isles.

Each individual country of the civilized world has had its own problems in respect to its anatomical laws and dissection. Ireland is one which stands unique in the early history of anatomy, because it had an unlimited source of subjects. Responsible for this to a large extent, was perhaps its poor economic status. In Dublin, a center of medical education, the anatomists had access to Bully's Acre, where many paupers were buried. In 1826, 600 to 800 cadavers were used in the schools in that city. It was calculated that as many as 1,500 to 2,000 were removed in that year, many of which were exported to England and Scotland. The trade in these became so great, because high prices were received, that the local anatomical teachers began to suffer. The standards of teaching became low during the Crimean War (1854-1856), between Russia and Turkey. England allied herself with the latter which immediately created a need for army surgeons. There was a rush of students into medical schools so that the standards fell; cramming was widely practiced and the grind-rooms were filled to overflowing.

The history of dissection in France has been characterized by lack of emotional incidents. Anatomy was more stabilized there than in the British Isles and the country was never highly infested with resurrectionists. This was due to the early development of adequate anatomical laws which did not permit dissection of executed murderers, removing one of the main stigmas attached to the practice. To violate a sepulchre meant fine and imprisonment. Before pathology began to claim a share of the bodies for autopsy purposes, the medical school in Paris received as many as 2,000 per year, afterwards 1,000 to 1,200 . The policy of permitting students to dissect began early. Exhumation did not exist and the people did not oppose dissection although some had an aversion to it. On the whole, there was a deep conviction of its utility. Cadavers were cheap for the students and they were free to doubt and dispute what they were taught. 
At first the supply of subjects was plentiful in Germany, probably up to 1882. After this, relatives claiming the bodies of their kin, the activity of burial societies and the zeal exhibited by priests, embalmers and gravediggers to collect fees, created a scarcity. During the 1928-1929 academic season, 2,277 medical students were in Berlin alone; as many as seventeen studied on one specimen. Sometimes, the class was divided in half, each taking turns in dissecting on one. One brain sufficed for twentyfive to thirty pupils. Teachers were overloaded with work because there were too few of them.

The same fate befell Holland as Germany. In 1934, many universities there, as well as in other parts of Europe, were experiencing difficulties in obtaining a sufficient number of cadavers. In that country, they had to be exported from the colonies. Due, in part, to the effectiveness of private, charitable and religious societies, which claimed nearly every body, the flow of subjects to the medical schools in Austria practically stopped. This began as early as 1912. By 1921, first year students had little opportunity to dissect and had to be satisfied with skeletons and museum specimens. Now and then, a group of students could watch another anatomize a subject. By 1930, the problem was no better.

Very little factual material is available on the latest events in Switzerland, Portugal, Italy or Spain. Spain does not have a spectacular record in human dissection because the Spanish government was reluctant to authorize the practice. It did not get under way until the 19th Century.

In China, the medical profession has always been looked upon as a fourth- or fifth-rate occupation. Human dissection is contary to their ideas of future life and it is generally looked upon with horror. In 1913, dissection of a Chinaman, especially by a foreigner would have been sufficient grounds for a riot. Medical education and schools there are tolerated rather than encouraged. In 1920, only twelve out of twenty-six institutions had any sort of dissection, and there was no regular and sufficient source of 
supply. The majority of teachers relied mostly on models. Skeletons, by contrast, were more easy to obtain.

Japan has had a more modern approach to the problem. In 1920 , anatomical material was plentiful for twenty-five medical schools. The supply was controlled by the government and bodies were obtained from prisons, workhouses, university hospitals and old people's homes. Equipment was up-to-date and most teachers were trained in foreign schools.

Indochina had one medical school in 1913 and it served of little practical value. Courses were abbreviated and were given as a means to an end; little effort was made toward an evolution to a higher education.

In Iran, only one existed in 1933. Teaching there was highly unsatisfactory and dissection was totally neglected due to its forbiddance by Mohammedanism. The bodies of the dead were left exposed to be eaten by birds. Cremation and burial were considered to be sacrileges of the highest order. Contact with the dead was avoided because death was the greatest sin and considered contagious.

The anatomical problems in the United States have been somewhat the same as in other parts of the civilized world. Here, there has been a general hesitancy in developing adequate dissection laws; there have been incidents of body snatching, indictments, high emotional feelings, riots and even murder, the last to a lesser extent than on the British Isles. Within the past few centuries, our country has been colonized, it succeeded in obtaining its independence; its population quickly expanded and continued to do so; it went through the Civil War and state after state was added to the Union. This necessitated more and more medical schools and students. Only one minor, Federal law to regulate the flow of bodies has been enacted. Whenever medical schools were established within a state sovereignty, the legislators were confronted with a delicate and unusual situation, which they either resisted, evaded or, in general, enacted feeble laws.

Four hundred fifty-nine private and state medical schools have functioned at one time or another in this nation, of which 
eighty-one have survived. The peak in the number was reached during the first decade of the 20th Century. Many were private, fly-by-night establishments and they became successful targets for medical standardizing boards.

Most of the historical information available on human dissection revolves around the oldest medical schools in the United States particularly those situated along the Atlantic. Coast and in certain parts of the midwest. The initial problems of these institutions were about the same. It is evident that anatomical laws were either lacking or inadequate in the early history of the United States. Those which were enacted permitted dissections to be done on a few bodies of executed criminals, which attached an infamy to the practice. To meet the needs, body snatching was established first by gentlemen of the profession: surgeonis, teachers and students. These were eventually replaced by commercial resurrectionists and their methods, exploits and competition matched those who plied their trade in Great Britain.

It would be difficult to find a community of the past which was lenient and tolerant toward the practice of grave robbing. On the basis of deep-seated convictions, the reactions of the people were defensive toward their buried dead. When thieving was detected, mob response was usually the rule. More rioting has probably occurred in the United States than any other country. Sometimes, it was of violent proportions where bodily harm was inflicted on suspects. The protective measures utilized by the masses against body snatching were the following: filling the graves with bundles of straw, sticks or large stones; placing thick planks across the coffin; building special vaults of heavy stone guarded by iron doors and grave watching.

As for the resurrectionists, they all followed a standard procedure. A low class of men worked in secrecy in the dead of night during the cold seasons with special types of tools and a horse and cart. They needed to scout funerals, locate the grave, approach the coffin by a certain technique, open it, remove the corpse, leave its clothing and restore the soil as nearly as possible to its former state. Then the body had to be delivered and sold to the anatomist. It was in potter's fields where most such specimens were obtained. 
Dissections had to be made quickly, within a week, for obvious reasons, and students often worked all night.

Between 1765 and 1852 , at least thirteen riots, possibly more, occurred within the United States. These took place in the states of Illinois, Maryland, Massachusetts, New York, Ohio, Pennsylvania and Vermont. They included mob attacks on the homes of anatomists, hospitals, medical schools and a hotel. The worst that happened was the closing or demolition of schools; also, one professor of anatomy was seriously shot in the arm and paralyzed for life, a student was killed, police were sometimes badly beaten and on one occasion the militia was called out.

More changes have probably occurred in anatomical teaching in the United States in the past fifty years than in any other country. At the turn of the century, many fly-by-night medical schools existed, standards were low, competition was keen and the cost per student was high; most teachers were part-time surgeons, whose income was derived from their practice, and they taught authoritatively. Numerous standardizing agencies, official and unofficial, entered the picture, and collectively asserted that anatomy, in spite of its great importance, was in bad repute; in fact, they agreed that conditions bordered on the deplorable, the classes were overcrowded and anatomical departments lacked sufficient financial support. This eventually resulted in the following: employment of full-time teachers, shortening of clock-hours, inclusion of microscopic subjects and more monetary backing. This led to the almost total disappearance of the surgeon-anatomist who chose practice rather than teaching, and it marked the beginning of an influx of teachers with graduate school training.

One of the agencies responsible for determining the standards of student knowledge in medicine generally, has been the National Board of Examiners. In the past, with the essay type of exams in anatomy, they have referred to a maze of anatomic detail and the recent shift to the objective type may not have basically altered this situation. Unquestionably, a broad grasp of the subject is necessary to successfully cope with them.

Although the educators on the investigating committees of several organizations, in the past, have placed great value on the 
importance of anatomy in the medical curriculum, it has been suggested by certain critics that it is not a cultural subject, that such topics as human individuality, growth, the aging process, the endocrines and heredity should be considered at the expense of human dissection.

Because of standards imposed particularly during the first part of this century, the number of medical schools has been cut in half. Nevertheless, the number of freshman students has doubled and there has been an increase from an average of thirty-two per class in 1915 to ninety-four in 1955. It is estimated that about 5,000 cadavers annually are now needed to supply all those required to study anatomy in the United States.

Only in rare instances, have state anatomical laws been able to take care of the over-all demand for human cadavers. There is a wide variation in their make-up. The factors which influence a favorable supply are an adequate anatomical code, density of population and a poor economic condition. Those militating against a suitable quantity are prosperity in the economic status, increasing social welfare burials, legislation for old-age assistance, burial insurance, increased post-mortem examinations by pathologists, and laws which are very lenient in regarding claimants and in giving exemptions so that low priority is given to anatomical teaching.

In general, it can be said that cadaver supply to professional institutions in the United States has become an acute problem. It may be that it is not the people at large who are deeply opposed to anatomists utilizing the bodies of unclaimed dead for the promotion of anatomical science. By publicity, some medical institutions have carried their problems directly to the laymen with considerable success in obtaining willed bodies.

In respect to the historical problem of cadaver supply, there is no question but what there has been a constant struggle between two opposing groups, the health profession, forming a minority, on the one hand, and the sentiments of the great nonmedical populace, on the other. Rationalizing and discussions across the table have not been responsible, perhaps, for any radical changes in the anatomical laws of most countries. Rather, progress, has been accomplished more on an emotional basis. 
Violent opinions and reactions, have occurred in the past, in parts of the civilized world, as an understandable response to the commercialism, subterfuge, thievery and murder by a low-class of people. When things have gotten out-of-hand, as in the case of the murders in Scotland, England and Maryland, or when riots have been invoked by outraged mobs, legislators have more quickly evaluated the pros and cons of the question, and usually new laws or amendments to old ones, have been forthcoming.

Any one who has studied the history of anatomy cannot fail, I believe, to be impressed with the attitude of surgeons and anatomists of the past in respect to their regard for the human body. On the whole, they have been impressed with its beauty, architecture, and complexity; their approach has been philosophical and broad. Both they and their subject have been often maligned, yet they have stood their ground, always trying to meet the standards imposed upon them, whether written or unwritten. The same is probably as true today as yesterday. In addition, they have had a deep faith in the theoretical and practical value of the subject and what a thorough knowledge of the structural make-up of man has meant to the profession since the Renaissance and what it means to each medical student today.

The outstanding feature of the human body is its complexity which leads inevitably back to its morphology. Because of this factor alone, it takes time to completely dissect it; there are no short cuts. In the past fifty years, there has been an attrition in the number of hours devoted to gross anatomy, and today many departments are teaching all of the anatomical subjects within one semester. In terms of balance, this condition may eventuate in all schools in the United States. Dissection probably has no place for the man who is insensitive to structural beauty, who lacks a sense of its importance, who has a regard for clock-hours or who lacks historical perspective.

Although grave robbing is a thing of the past, the problem of cadaver supply remains. It is receiving more general publicity than ever before. It seems likely that progress, if it occurs, will not be made on an emotional basis, as in the past, but rather by enlightening the public and particularly that part of it which has 
the health and welfare of mankind at heart. Rationality may decide that there is no worthwhile and available substitute for the exploration of man's geography by each medical student. Dissection is truly one means whereby man can study man. 



\section{BIBLIOGRAPHY}

1. Abbot, S. L. (correspondence): A reminiscence of Dr. Holmes. Boston M. \& S. J., 132:267, 1895.

2. Abernethy, J.: The introductory anatomical lecture delivered at the theatre of anatomy, St. Bartholomew's Hospital (London, Oct. 1825). Lancet 1:33-41, 1825.

3. Addison, J. T.: Life Beyond Death in the Beliefs of Mankind. Boston, Houghton, 1932.

4. Allen, R. B.: Medical Education and the Changing Order. New York, Commonwealth Fund, 1946.

5. Anson, B. J.: The history of anatomy in medical education. Quart. Bull. Northwestern Univ. M. School, 30:80-95, 1956.

6. Arey, L. B.: Resurrection men. Quart. Bull. Northwestern Univ. M. School, $14: 209-219,1940$.

7. Atchley, D.: The Effect of Modern Development in the Science of Medicine upon the Undergraduate Curriculum, in Trends in Medical Education. The New York Academy of Medicine, Institute on Medical Education, 1947. Edited by M. Ashford. New York, Commonwealth Fund, 1949.

8. Bacon, C. B.: Historical epitome of anatomy. Brooklyn M. J., 17:20-24, 1903.

9. Bailey, J. B.: The Diary of a Resurrectionist, 1811-1812. London, Swan Sonnenschein, 1896.

10. Bailey, P.: A Florentine anatomist. Bull. Johns Hopkins Hosp., 22:140$143,1911$.

11. Bainton, R. H.: The present state of Servetus studies. J. Modern Hist., $4: 72-92,1932$.

12. Hunted Heretic, Life and Death of Michael Servetus (1511-1553). Boston, Beacon Press, 1953.

13. Baker, F.: The two Sylviuses. Bull. Johns Hopkins Hosp., 20:329-339, 1909.

14. Baldwin, J. F.: Grave robbing. Ohio State M. J., 32:754-757, 1936.

15. Ball, J. M.: Andreas Vesalius the Reformer of Anatomy. St. Louis, Medical Science Press, 1910.

16. : The Sack'em-up Men. An Account of the Rise and Fall of the Modern Resurrectionists. London, Oliver \& Boyd, Ltd., 1928.

17. Bardeen, C. R.: Anatomy in America Bull. Univ. Wisconsin, 115:87-118, 1905. 
18. : Report of the sub-committee on anatomy to the Council of Medical Education of the American Medical Association, April, 1909. Anat. Rec., 3:415-439, 1909.

19. Barker, L. F.: On the study, of anatomy. Bull. Johns Hopkins Hosp., 12: $87-95,1901$.

20. Belt, E.: Leonardo the Anatomist. Logan Clendening Lectures on the History and Philosophy of Medicine. Lawrence, Univ. Kansas Press, 1955.

21. Blaine, G.: Biological teaching models and specimens. Lancet, 2:337-340, 1951.

22. Blanton, W. B.: Augustus Lockman Warner, 1807-1847. Founder of Medical College of Virginia, first professor of surgery and first dean. Ann. M. Hist., 3rd S. 4:1-9, 1942.

23. Brash, J. C.: The Haslam Oration on surgeon anatomists in the history of anatomy. Birmingham M. Rev., 5NS:146-163, 191-206, 1930.

24. Brinton, D. G.: Religions of Primitive Peoples. New York, Putnam, 1899.

25. Brown, H. M.: The anatomical habitat of the soul. Ann. M. Hist., 5: $1-22,1923$.

26. Browning, W. W.: Remarks on the teaching of practical anatomy. Brooklyn M. J., 8:329-341, 1894.

X27. Buck, A. H.: The Growth of Medicine from the Earliest Times to about 1800. New Haven, Yale, 1917.

28. Burr, C. W.: Burke and Hare and the psychology of murder. Ann. M. Hist., 1:75-82, 1917.

29. : Galen. Ann. M. Hist., 3NS:209-217, 1931.

X30. Camac, C. N. B.: Imhotep to Harvey. Backgrounds of Medical History. New York, Hoeber, 1931.

31. Carpenter, C. C.: Integration and organization of the medical curriculum. J. A. Am. M. Coll., 22:30-37, 1947.

X 32. Castiglioni, A.: A History of Medicine. Translated and edited by E. $B$. Krumbhaar. New York, Knopf, 1941.

33. Cave, A. J. E.: Ancient Egypt and the origin of anatomical science. Proc. Roy. Soc. Med., 43:568-571, 1950.

X 34. Celsus, A. C.: De Medicina. 2 volumes. Translation by W. G. Spencer. Cambridge, Harvard, 1935.

35. Chapin, W. A. R. (editor): History University of Vermont College of Medicine. Hanover, New Hampshire, Dartmouth Printing Company, 1951.

36. Chatard, J. A.: Avicenna and Arabian medicinc. Bull. Johns Hopkins Hosp., 19:157-160, 1908.

37. Clark, E.: Anatomy in the Far Last. Anat. Rec., 7:237-245, 1913.

38. Clements, I. P.: Objectives in teaching anatomy: J. A. Am. M. Coli., 14:170-174, 1939. 
39. Coleman, R. B.: The illustration of human anatomy before Vesalius. Surg. Gynec. \& Obst., 90:500-507, 1950.

40. Commission on Medical Education: Final Report of the Commission on Medical Education. New York, Office of the Director of Study, 1932.

41. Comrie, J. D.: Early anatomical instruction at Edinburgh. Edinburgh M. J., 29:273-296, 1922.

42. Conel, J. L.: Instruction in anatomy in Germany. J. A. Am. M. Coll., 6: 36-46, 94-106, 1931.

43. Cooper, B. B.: The Life of Sir Astley Cooper, Bart., interspersed with sketches from his note-books of distinguished contemporary characters. 2 volumes. London, John W. Parker, 1843.

44. Cooper, S.: The medical school of Montpellier in the fourteenth century. Ann. M. Hist., 2NS:164-195, 1930.

45. Cordell, E. F.: The Medical Annals of Maryland. 1799-1899. Baltimore, Williams \& Wilkins, 1903.

46. Corner, G. W.: Anatomists in search of the soul. Ann. M. Hist., 2:1-7, 1919.

X47. Clio Medica Anatomica. New York, Hoeber, 1930.

48. _ : The rise of medicine at Salerno in the twelfth century. Ann. M. Hist., 3NS:1-16, 1931.

49. Correspondence (New York): An anatomical board. Lancet, 2:1228, 1902.

50. _ (Vienna): Proposed limitation of the number of students of anatomy in Vienna. Lancet, 2:489, 1183, 1912.

51. (Vienna): Difficulties in teaching anatomy. Lancet, 1: $1267,1921$.

52. Cowdry, E. V.: Anatomy in China. Anat. Rec., 20:31-60, 1920a.

53. _ Anatomy in Japan. Anat. Rec., 18:67-95, 1920 b.

54. _ : Taoist ideas of human anatomy. Ann. M. Hist., 3:301309, 1921.

55. Creswell, C. H.: The Royal College of Surgeons of Edinburgh: anatomy in the early days. Edinburgh M. J., NS12:141-156, 1914.

56. Cruikshank, W. J.: The antagonism of the church to scientific progress during the Middle Ages: The facts of the case, and a reply to the criticism of Dr. James J. Walsh. Med. Libr. and Hist. J., 4:56-85, 1906.

57. Crummer, L.: Early anatomical fugitive sheets. Ann. M. Hist., 5:189209, 1923.

X8. Cumston, C. G.: An Introduction to the History of Medicine. From the time of the Pharaohs to the end of the XVIIIth Century. New York, Knopf, 1926.

59. Cunningham, D. J.: Inaugural Address Delivered at the Opening of the New Anatomical Theatre, Trinity College, Dublin, on Nov. 2, 1885. Dublin, University Press, 1885. 
60. : Introductory address to the class of anatomy in the University of Edinburgh, 13th October, 1903. Edinburgh M. J., 56, NS14:389-404, 1903.

61. Dana, C. L.: The Peaks of Medical History: An Outline of the Evolution of Medicine for the Use of Medical Students and Practitioners. Second edition. New York, Hoeber, 1928.

62. Davis, N. S.: Contributions to the History of Medical Education and Medical Institutions in the United States of America, 1776-1876. Washington, Government Printing Office, 1877.

63. Dawson, W. R.: Egypt's place in medical history, in Science, Medicine and History, edited by E. A. Underwood. Vol. I. New York, Oxford, 1953.

64. De Lint, J. G.: Frederich Hoffmann's, Man as a Machine. M. Life, 41:169-176, 1934.

65. Dempster, W. T.: European anatomy before Vesalius. Ann. M. Hist., 6:307-319, 448-469, 1934.

66. Deniker, J.: The Races of Man: An Outline of Anthropology and Ethnology. New York, Scribner, 1906.

67. Dobrizhoffer, M.: Discussion on death, in Primitive Heritage: An Anthropological Anthology, edited by Margaret Mead and N. Calas. New York, Random House, 1953, pp. 534-536.

68. Dobson, J.: The anatomizing of criminals. Ann. Roy. Coll. Surgeons England, 9:112-120, 1951.

69. Dock, W.: Anatomical dissection: Its place in the curriculum. J.A. Am. M. Coll., 17:383-386, 1942.

70. Doolin, W.: In the days of Vesalius. Irish J. M. Sc., 6S:97-110, 1933.

71. 는 Dublin's surgeon-anatomists. Ann. Roy. Coll. Surgeons England, 8:1-22, 1951.

72. Dwight, T.: Boston Medical Library Association, Holmes Memorial Meeting. Boston M. and S. J., 131:584-590, 1894.

73. : Anatomy laws versus body snatching. Forum, 22:493$502,1896$.

74. Editorial: On human dissection. Lancet, 1:562-563, 1829.

75.

76. $380,1891$.

77. B Body snatching in Indiana. M. Standard, 25:644, 1902.

78. _ The shortage of anatomical subjects. Lancet, 1:123, 1914.

79. Edwards, L. F.: The Ohio anatomy law of 1881. Ohio M. J., 46:11901192. 1950; $47: 49-52,143-146,1951$.

80. America. Bull. Hist. Med., 25:178-184, 1951.

81. Cincinnati's Old Cunny, a notorious purveyor of human flesh. Ohio M. J., 50:466-469, 1954. 
82. Eichler, Lillian: The Customs of Mankind with notes on modern etiquette and the newest trend in entertainment. Garden City, N. Y., Doubleday, 1924.

83. Elliston, W. A.: Some incidents in the evolution of the modern physician. Lancet, 2:359, 1900.

84. Elsberg, C. A.: The Edwin Smith Surgical Papyrus and the diagnosis and treatment of injuries to the skull and spine 5000 years ago. Ann. M. Hist., 3NS:271-279, 1931.

85. Erinensis: On the exportation of dead bodies from Ireland to England and Scotland (a letter to the editor). Lancet, 1:775-777, 1829.

86. Figge, F. H. J.: Anatomy 150 years ago. The Kalends, 36:10-14, 1957.

87. Fisher, G. J.: Historical and biographical notes. A series of sketches of the lives, times and works of the old masters of anatomy and surgery. XIV. Herophilus and Erasistratus. The Medical School of Alexandria B.C. 320-250. Ann. Anat. \& Surg., 4:28-36, 1881a.

88. : Historical and bibliographical notes. A series of sketches of the lives, times and works of the old masters of anatomy and surgery. XV. Claudius Galenus A.D. 130-200. Ann. Anat. \& Surg., 4: 115-122, 163-170, 209-218, 280-287, $1881 \mathrm{~b}$.

89. Flexner, A.: Medical Education in the United States and Canada. A report to the Carnegie Foundation for the Advancement of Teaching. New York, Carnegie Found., 1910.

90. Foreign letter (United Kingdom): Shortage of bodies for dissection. J. A. M. A., 163:486, 1957.

91. Franchini, G.: The origin of the University of Bologna. Ann. M. Hist., 4NS:187-198, 1932.

92. Frank, M.: Resurrection days. Interstate M. J., 14:293-310, 1907.

93. Fraser, D.: Oliver Wendell Holmes. McGill M. J., 19:211-217, 1950.

94. Frazer, J. E. S.: Alexandrian and pre-Alexandrian anatomy. St. Mary's Hosp. Gaz., 26:3-5, 12-14, 1920.

95. Frazer, J. G.: The Golden Bough. A Study in Magic and Religion. Vol. I, Abridged Ed., New York, Macmillan, 1948.

96. Fulton, J. F.: Michael Servetus, Humanist and Martyr. New York, Reichner, 1953.

97. Garrison, F. H.: The personality of Vesalius. Buli. Johns Hopkins Hosp., 26:121-123, 1915.

98. - An Introduction to the History of Medicine. Fourth edition. Philadelphia, Saunders, 1929.

99. : Persian medicine and medicine in Persia. Bull. Inst. Hist. Med., 1:129-153, 1933.

100. Gask, G. E.: Early medical schools. III. The School of Alexandria. Ann. M. Hist., 3rd S. 2:383-392, 1910.

101. Gordon, B. L.: Medicine among the ancient Hebrews. Ann. M. Hist., 4: 219-235, 1942. 
102. : The Romance of Medicine. Philadelphia, Davis, 1944.

103. Green, R. M.: A Translation of Galen's Hygiene (De sanitate tuenda). Springfield, Thomas, 1951.

104. Gregg, A.: Perspectives on the teaching of anatomy. J. A. Am. M. Coll., $17: 273-282,1942$.

105. Guttmacher, A. F.: Bootlegging bodies. Bull. Soc. M. Hist., Chicago, $4: 353-402,1935$.

106. Haggard, H. W.: Devils, Drugs and Doctors. New York, Harper, 1929.

107. Hammett, F. S.: The anatomical knowledge of the ancient Hindus. Ann. M. Hist., 1:325-333, 1929.

108. Harrington, T. F.: The Harvard Medical School. A History, Narrative and Documentary. 1782-1905. 3 Volumes. New York, Lewis, 1905.

109. Harris, D. F.: On a Latin translation of the complete works of Galen by Andrea Laguna, M. D., the Spaniard, Strassburg, 1604 with notes, dedications, a life of Galen and index. Ann. M. Hist., 2:384-390, 1919.

110. Hartwell, E. M.: The hindrance to anatomical study in the United States, including a special report of the struggles of our early anatomical teachers. Ann. Anat. \& Surg., 3:209-225, 1881a.

111. in the U. S. Ann. Anat. \& Surg., 4:8-14, 1881b.

112. Harvard Medical School: The Harvard Medical School: 1782-1906. Boston, 1906.

113. Hemmeter, J. C.: Michael Servetus, discoverer of the pulmonary circulation-his life and work. Bull. Johns Hopkins Hosp., 26:318-326, 1915.

114. Herringham, W.: The life and times of Dr. William Harvey. Ann. M. Hist., 4NS:109-125, 249-272, 347-363, 491-502, 575-589, 1932.

115. Homer: The Iliad of Homer. Translated by Samuel Butler. New York, Black, 1942.

116. Hume, E. E.: Spanish colonial medicine. Bull. Inst. Hist. Med., 2:215$230,1934$.

117. Hume, E. H.: Medicine in China, old and new. Ann. M. Hist., 2NS: 272-280, 1930.

118. Jenkins, G. B.: The legal status of dissecting. Anat. Rec., 7:387-399, 1913.

119. Johnson, C. B.: Getting my anatomy in the sixties. Bull. Soc. M. Hist., Chicago, 3:109-115, 1923.

120. Johnson, V.: Medicine after the war. J. South Carolina M. A., 41: $1-5,1945$.

121. Jonas, H. C.: The history of the study of anatomy. A retrospect. Lancet, 2:363-364, 1922.

122. Kelly, H. A.: The barred road to anatomy. Bull. Johns Hopkins Hosp., 19:196-201, 1908. 
123. Kempf, E. J.: From Hippocrates to Galen. Med. Libr. and Hist. J., 2: 282-307, 1904.

124. Kerr, A. T.: On the preservation of anatomical material in America by means of cold storage. Bull. Johns Hopkins Hosp., 12:117-123, 1901.

125. Khairallah, A. A.: Arabic contributions to anatomy and surgery. Ann. M. Hist., 3rd S. 4:409, 1942.

126. King, H. D.: Henry VIII, a most liberal patron of medicine. New York State M. J., 107:151-153, 1918.

127. Knox, J. H. M.: The medical life of Oliver Wendell Holmes. Bull. Johns Hopkins Hosp., 18:45-51, 1907.

128. Korns, H. M.: Notes on the medical history of Vienna. Ann. M. Hist., 9:345-370, 464-481, 1937.

129. Krumbhaar, E. B.: The early history of anatomy in the United States. Ann. M. Hist., 4:271-286, 1922.

130. Ladenheim, J. C.: "The Doctors' Mob" of 1788. J. Hist. Med. \& Allied Sc., 5:23-43, 1950.

131. Laurie, S. S.: The Rise and Early Constitution of Universities. New York, Appleton, 1896.

132. Levy-Bruhl, L.: Primitive Mentality. Translated by Lillian A. Clare. New York, Macmillan, 1923.

133. Lonsdale, H.: A Sketch of the Life and Writings of Robert Knox. London, Macmillan, 1870.

134. Macalister, A.: A sketch of the history of anatomy. Dublin J. M. Sc., 1: $1-18,1884$.

135. _ The History of the Study of Anatomy in Cambridge. A lecture delivered January 29, 1891, on the opening of the new anatomical lecture room. Cambridge, Cambridge Univ. Press, 1891.

136. $\quad$ James Macartney. London, Hodder \& Stoughton, 1900.

137. MacCallum, W. G.: The school of Montpellier. Bull. Johns Hopkins Hosp., 19:296-301, 1908.

138. Mackenzie, W. M.: An appeal to the public and to the legislature on the necessity of affording dead bodies to the schools of anatomy, by legislative action. Glasgow, 1824. Westminster Rev., 2:59-96, 1824.

139. Macmichael, W.: The Gold-Headed Cane. Fifth edition. London, Kimpton, 1923.

140. Major, R. H.: John Conrad Brunner and his experiments on the pancreas. Ann. M. Hist., 3rd S. 3:91-100, 1941.

141. Mall, F. P.: Anatomical material-Its collection and its preservation at Johns Hopkins anatomy laboratory. Bull. Johns Hopkins Hosp., 16:38-42, 1905 .

142. : On some points of importance to anatomists. Anat. Rec., 1:24-29, 1906.

143. Malloch, A.: Galen. Ann. M. Hist., 8:61-68, 1926. 
144. McGuire, S.: Hunter Holmes McGuire, M.D., L.L.D., Ann. M. Hist., 10NS:1-14, 136-161, 1938.

145. McMurrich, J. P.: Leonardo da Vinci, the Anatomist (1452-1519). Baltimore, Williams \& Wilkins, 1930.

146. Metchnikoff, E.: The Nature of Man: Studies in Optimistic Philosophy. New York, Putnam, 1907.

147. Mettler, Cecilia C.: History of Medicine. Philadelphia,, Blakiston, 1947.

148. Meyer, A. W.: Anatomy acts of California. A survey of former and present laws. California and West. Med., 33:703-707, 1930.

149. Middleton, W. S.: Joseph Leidy, scientist. Ann. M. Hist., 5:100-112, 1923a.

150. - William Edmonds Horner (1793-1853). Ann. M. Hist., 5:33-44, 1923b.

151. : John Morgan, father of medical education in North America. Ann. M. Hist., 9:13-26, 1927.

152. - William Shippen, Junior. Ann. M. Hist., 4NS:440-452, 538-549, 1932.

153. _ Joseph Parrish, Quaker preceptor. Ann. M. Hist., 3rd S. 4:343-369, 1942.

154. Miller, W. S.: Abraham Chovet: An early teacher of anatomy in Philadelphia. Anat. Rec., 5:147-171, 1911.

155. : Granville Sharp Pattison. Bull. Johns Hopkins Hosp., 30:98-104, 1918.

156. Miscellany: Medical Tributes to Dr. Holmes. Boston M. and S. J., 131:423-425, 1894.

157. Montagu, M. F. A.: Vesalius and the Galenists, in Science, Medicine and History, edited by E. A. Underwood. Vol. I. New York, Oxford, 1953.

158. Moore, G. F.: History of Religions. Vol. I.' New York, Scribner, 1913.

159. _ The Birth and Growth of Religion; being the Morse lectures of 1922. New York, Scribner, 1923.

160. Norwood, W. F.: Medical Education in the United States before the Civil War. Philadelphia, Univ. Penn. P'ress, 1944.

161. O'Malley, C. D., and J. B. deC. M. Saunders: Andreas Vesalius Imperial Physician, in Science, Medicine and History, edited by E. A. Underwood. Vol. I. New York, Oxford, 1953.

162. Osler, W.: An Alabama student. Bull. Johns Hopkins Hosp., 7:6-11, 1896.

163. : Michael Servetus. Bull. Johns Hopkins Hosp., 21:1-11, 1910.

$\times 161$. The Evolution of Modern Medicine. New Haven, Yale, 1922.

165. Overholser, M. D., W. F. Alexander, and Mildred Trotter: Can Missouri schools continue the teaching of human anatomy effectively? Missouri Med., 53:474-476, 1956. 
166. Packard, F. R.: The first American medical school and its founders. M. Standard, 25:464-468, 1902.

167. : History of the School of Salernum, in Harington, J.: The School of Salernum. Regimen Sanitatis Salernitanum. New York, Hoeber, 1920.

168. : The practice of medicine in Philadelphia in the eighteenth century.. Ann. M. Hist., 5NS:135-150, 1933.

169. : William Cheselden. Some of his contemporaries and their American pupils. Ann. M. Hist., 9:533-548, 1937.

170. Park, R.: An Epitome on the History of Medicine. Philadelphia, Davis, 1908.

171. Pilcher, L. S.: The Mondino myth. Med. Libr. and Hist. J., 4:311-331, 1906.

172. Prendergast, J. S.: The background of Galen's life and activities, and its influence on his achievements. Proc. Roy. Soc. Med., 23 II:1131$1148,1930$.

173. Ranke, H.: Medicine and surgery in ancient Egypt. Bull. Inst. Hist. Med., 1:237-257, 1933.

174. Reisner, G. A.: The Egyptian Concept of Immortality. The Ingersoll Lecture, 1911. Boston, Houghton, 1912.

175. Report of the Council on Medical Education. J.A. M. A., 46:1853-1858, 1906.

176. Report of the Third Teaching Institute, Association of American Medical Colleges. The teaching of anatomy and anthropology in medical education, edited by Lura S. Jackson. J. M. Educ., 31 (no. 10, part 2): 45-66, 1956.

177. Report to American Surgical Association of the committee on undergraduate medical education. Tr. Am. S. A., 68:523-554, 1950.

178. Robinson, G. C.: The development of grave robbing in England. Bull. Johns Hopkins Hosp., 16:421-444, 1905.

179. Rohrer, C. W. G.: Professor Samuel D. Gross: America's foremost surgeon. Bull. Johns Hopkins Hosp., 23:83-94, 1912.

180. John Hunter: His life and labors. Bull. Johns Hopkins Hosp., 25:10-25, 1914.

181. Rolleston, H.: The early history of the teaching of I. Human anatomy in London, Ann. M. Hist., 3rd S. 1:203-216, 1939.

182. Sabin, Florence R.: Franklin Paine Mall. The Story of a Mind. Baltimore, Johns Hopkins Press, 1931.

X 183. Sarton, G.: Galen of Pergamon. Lawrence, Univ. Kansas Press. 1954.

184. Sigerist, H. E.: American Medicine. New York, Norton, 1934.

$\times 185$. : A History of Medicine. Vol. I. Primitive and Archaic Medicine. New York, Oxford, 1951. 
188. South, J. F.: Memorials of the Craft of Surgery in England. Edited by D'A. Power, New York, Cassell, 1886.

189. Special feature article: Supply of anatomical material. Bull. Med. Research, 10 (2): 11-25, 1955.

190. Sprigge, S. S.: The Life and Times of Thomas Wakley. London, Longmans, 1897.

191. Streeter, E. C.: Leonardo da Vinci and the practice of dissections among the Florentine artists. Long Island M. J., 24:144-147, 1930.

192. Taylor, H. O.: Greek Biology and Medicine. Boston, Marshall Jones, 1922.

193. Tilton, Eleanor M.: Amiable Autocrat. A Biography of Dr. Oliver Wendell Holmes. New York, Schuman, 1947.

194. Toner, J.: Contributions to the Annals of Medical Progress and Medical Education in the United States before and during the War of Independence. Washington, Government Printing Office, 1874.

195. Turner, E. D. et al: Medical education in the United States and Canada. J. A. M. A., 161:1637-1678, 1956.

196. Viets, H. R.: A Brief History of Medicine in Massachusetts. Boston, Houghton, 1930.

197. Waite, F. C.: An episode in Massachusetts in 1818 related to the teaching of anatomy. New England J. Med., 220:221-227, 1939.

198. _ G Grave robbing in New England. Bull. M. Library A., 33: 272-294, 1945a.

199. New England. New England J. Med., 233:717-718, 1945b.

200. $\quad$ The Story of a Country Medical College. A History of the Clinical School of Medicine and The Vermont Medical College, Woodstock, Vermont. Brattleboro, Vermont Printing Company, 1945c.

201. Wakley, T.: Mr. Wakley's evidence before the parliamentary committee. Lancet, 1:789-793, 1829.

202. Walsh, J. J.: The popes and the history of anatomy. Med. Libr. \& Hist. J., 2:10-28, 1904 .

203. : Galen's writings and influences inspiring them. Part III. Ann. M. Hist., 7NS:428-437, 570-589, 1935. 204. $\sqrt{\text { Hist., 9:132-143, 1927. }}$ : Galen's studies at the Alexandrian school. Ann. M.

205. Walton, G. I.: The study of anatomy in the Leipzig University. Boston M. and S. J., 106:389-390, 1882.

206. Warbasse, J. P.: The Doctor and the Public. A Study of the Sociology, Economics, Ethics, and Philosophy of Medicine, Based on Medical History. New York, Hoeber, 1935.

207. Warren, E.: The Life of John Collins Warren, M.D. Compiled chiefly from his autobiography and journals. 2 Vols. Boston, Ticknor and Fields, 1860. 
208. Watson, B. P.: "How we learned about the human body", Chapt. I in Pool, E. H.: Medicine and Mankind. New York, Appleton, 1936.

209. Weaver, G. H.: Beginnings of medical education in and near Chicago. Bull. Soc. M. Hist. Chicago, 3:339-383, 1923-1925

210. Weaver, J. C.: Anatomy before Vesalius. J. M. A. Georgia, 19:315-318, 1930.

211. Weiskotten, H. G., A. M. Schwitalla, W. D. Cutter, and H. H. Anderson: Medical Education in the United States. Prepared for the Council on Medical Education and Hospitals of the American Medical Association. Chicago, American Medical Association, 1940.

212. Welch, W. H.: The times of Vesalius. Bull. Johns Hopkins Hosp., 26: 118-120, 1915.

213. Whipple, A. O.: A study of the results of the examinations in anatomy by the American Board of Surgery. J. A. Am. M. Coll., 18:185-191, 1943.

214. Wiedermann, A.: The Ancient Egyptian Doctrine of the Immortality of the Soul. London, H. Grevel and Co., 1895.

215. Wood, C. T.: Death and Beyond. A Study of Hebrew and Christian Conceptions of the Life to Come. New York, Longmans, 1920.

216. Woodburne, R. T., and E. Gardner: Anatomical materials and anatomical laws. Bull. M. Research, 8 (5):2-5, 1954.

217. Wright, J.: The blight of theory on the acquisition of anatomical knowledge by the ancient Egyptians. New York M. J., 108:973-976, 1918.

218. Yesko, S. A.: History of human dissections. M. Rec., 151:238-241, 1940. 219. Zilborg, G., and G. W. Henry: A History of Medical Psychology. New York, Norton, 1941. 


\section{INDEX}

\section{A}

Abbot, S. L., 208

Abernethy, J., 107

Achilles, 34

Achillini, Alessandro (1463-1525), 80

Addison, J. T., 27

Aeschylus, 45

Alexander the Great, 45

Allen, R. B., 247, 251

Alexandrian School of Anatomy, 44-50. 260-261

Aeschylus, 45

Alexander the Great, 45

appeal to students, 46

burning by Julius Caesar, 50

Celsus, 47,49

Cleopatra, 50

decline of liberalism in dissection, 50

duration of, 46

Erasistratus, 45, 46, 49

Eumenes of Cardia, 45

Euripides, 45

executed criminals, 47.48

fire, 7 th Century, 58

Galen, 53, 55

Gnosticism, philosophic-religious, 44

Herophilus, 45-48

liberality of dissection, 46

library, 50

I.ycos, 49

Marcus Aurelius Antonius (Caracalla), 50

Marinos, 49

Mark Antony, 50

museum, 45

pioncering anatomists, 46

Ptolemy I (Soter), governor of Egypt, 45

Quintos, 49

Seraphium, 45

Sophacles, 45 standards of teaching, 46

Tertullian, 48

American colonies

“An Act of Dueling" (1784), 196

Giles Firmin, first dissection, 184

John Eliot, 184

Potter's Ficld, as source of cadavers, 188

secrecy with cadavers in schools, 188 statutory laws, 182

student migration to Europe, 185

"The Body of Liberties," 182

American Medical Association, standardization of anatomy, 7, 181

American Revolution, influence on anatomy, 196

Anatomical theatres

at Trinity College (1711), 127

Barber-Surgeon's Hall (1567), 135

Edinburgh (1697), 155

Royal College of Physicians (15831641), 135

University of

Bologna, 71

Padua, 71

Vienna, 111

Anatomists

training of in,

Italy, 115

Paris, 115

Anatomy

Alexandrian School, 44-50

demand for subjects in British Isles, 117

Galenic, 51, 53, 55

in Middle Ages, 58-67

integration with other subjects, 7

interest in British Isles, 116

pre-Alexandrian, 38-43

antipathy, 40

cmbalming, 38 
standardization by American Medical Association, 7

struggle of, 3

Anatomy Acts

American colonies, 182

Austria, 111

British Isles, 116

dueling law (1784), 196

early 1800 's, 6

efficiency of, 186

England (1832), 7

Germany, 109

Illinois (1885), 242

Indiana (1879), 243

law of James I, 118

Maryland

$$
\begin{aligned}
& \text { (1832), } 230 \\
& \text { (1882), } 230 \\
& \text { (1890), } 230 \\
& \text { (1938 revision), } 230 \\
& \text { (1949 revision), } 230
\end{aligned}
$$

Massachusetts

(1647), 183

(1660), 183

(1831), 204-206

New England until 1820, 186

New Hampshire (1796), 185

New York (1789), 225

of 1604,183

Ohio

$$
\begin{aligned}
& \text { (1831), } 234 \\
& \text { (1840), } 235 \\
& \text { (1879), } 240 \\
& \text { (1880), } 241 \\
& \text { (1881), } 241
\end{aligned}
$$

Rhode Island (1655), 183

scarcity of, in colonies, 185

Scotland (1505-1705), 154

"The Body of Liberties," 182

United States

(1790), 194

(1900-1958), 252

status of, 271

uniformity of, 254

Vermont (1804), 186

Warburton Act

(1832), 153

weakness of, 132
Anatomy, teaching of

in British Isles, 116

innovations by Monro I, 156

in United States

changes in, 270

criticism of, 250-270

during 20th Century, 245-256

essentials, 248, 252

hours, 248

improvement, 250

increase in medical students, 252

place in curriculum, 248

prior to $1900,245-246$

reduction in number of medical schools, 252

significance of research, 249

Ancestors

worship of, 14

in ancient China, 20

Anson, B. J., 40, 242

Antropologium, Magnus Hundt's (1501), 88

Anubis, Egyptian deity, 25

Apollo, 34, 35

Apology to Astrology, Michael Servetus, 86

Arabians

accomplishments of, 62

Avicenna (980-1037), 58, 61

beliefs, in pre-Alexandrian era, 43

centers of learning, 61

Constantine, 61

influence in Middle Ages, 61-62, 262

investigative spirit, 61

leading scholars in Middle Ages, 61

Rhazes, 61

translations of Galen, 58

Arey, L. B., 135

Aristotle, 40

Artists

anatomical role of, in Renaissance, 74-79, 263

da Vinci, Leonardo, 74

Donatello, 74

Dürer, Albrecht, 74

human dissections of, 75

Michelangelo, 74

Pollaiuolo, Antonio, 74 
Ruysch, Frederick, Holland, 111

Titian, 74, 101

van Calcar, Jan Stephan, 97, 99

Verrocchio, Andrea, 75, 76, 78

Aryans, in ancient India, 30

Asklepieion, Medical shrine, 51

Association of American Medical Colleges, standardization of anatomy, 181, 247

Astrology, influence in Middle Ages, 60

Atchley, D., 247, 251

Attis, 37

Autopsies

by Sir Astley Cooper, 146

first, 145

Avicenna (980-1037), 58, 61

influence on Renaissance, 71

Austria

anatomical laws, 111

availability of cadavers, 111

number of medical students, 111

status of dissection, 111-112

\section{B}

\section{Babylonia}

burial procedures, 29

concepts of death, 259

divination in, 29

evil souls in, 29

fear of dead, 29

habitat of souls, 29

magic and religion combined, 29

nature worship in, 28

practice of magic, 28

priests in, 29

primitive polytheism in, 28

retribution in, 29

Bacon, C. B., 43

Bailey, J. B., 107, 109, 110, 150, 153

Bailey, P., 40, 50, 81

Bainton, R. H., 85, 86

Baker, F., 83, 85

Baldwin, J. F., 238, 240

Ball, J. M., 81, 85, 97, 99, 102, 104, 125, $134,135,137,138,139,142,150,154$, $155,156,174,184,185,222,230$
Baltimore

Cassidy, Patrick, executed criminal, 226

Davidge, J. B., 226

dissection in, 226

mob riot (1788), 226

murder of Emily Brown, 228-230

University of Maryland, 226-236

Paris of America, 228

Wiesenthal, C. F., 226

Barber-Surgeon's Company

Barber-Surgeon's Hall (1567), 135

Caius, John, 134

dissolution of (1745), 138

King Charles II and, 136

organized (1540), 134

separation of (1745), 139

Bardeen, C. R., 246, 247, 252

Barker, L. F., 42

Basel, printing of Fabrica, 99

Belief in immortality, 10

Bell, Charles, as a teacher, 158

Bell, John, founder of surgical anatomy, 157

Belt, E., 79

Berkshire Medical College (1823-1869), resurrections, 209

Bishop, London murderer, 152, 265

Black plague, psychological effect, 70

Blaine, G., 111

Blanton, W. B., 232

Body snatchers, see Resurrectionists

Body snatching, see Grave robbing

Bologna

Achillini, Alessandro, 80

D'Argellata, Pietro, 80

da Carpi, Berengario, 87

Mondino da Luzzi, 63-66

University of, 63-66, 71, 79

Vesalius at, 81, 95-99, 102

Book of the Dead, 26

Bootlegging bodies, see Grave robbing

Borthwick, John, pioneering anatomical teacher, Scotland, 154

Brahmanism

in ancient India, 30

priests, 30

Brash, J. C., 142, 158 
Brinton, D. G., 11, 12, 18

British Isles

anatomical and pathological museums, 119

anatomy laws, 116

as center of medical education, 115 , 264

cadaver availability, 116, 150

closure of medical schools (1829), 150

demand for cadavers, 117

grave robbing, 264

interest in anatomy, 116

law of James I, 118

rise of resurrectionists, 115-126, 265

standardization boards, 117, 264

student dissection, 264

surgeon-anatomists, 115

teaching anatomy, 116

Brookes, Joshua, proprietor of school of anatomy, London, 145

Brown, Emily, murdered in Baltimore, 228-230

Brown, H. M., 11

Brown, Owen, body of, 232

Browning, W. W., 40

Brunner, John C., professor at Heidelberg, dissection activities, 108

Buck, A. H., 46, 88

Buddhism, in ancient China, 22, 258

Bulletin of Medical Research ('55), 254

Bully's Acre, Dublin, source of cadavers, $129,131,266$

Burial

ceremonies, of primitive, 14 cremation, as early method of, 17 gravestones, significance, 17 in ancient

China, 21

India, 32

Japan, 23

in Babylonia, 29

motivating factor, 16

of dead, primitive, 14

of living humans, in ancient,

China, 21

Japan, 23

of Neanderthal man, 16

positions, 17
Burke, William, Edinburgh murderer, 161-179, 265

confession of, 172

hanging of, 172

McDougal, Helen, accomplice, 161

murder of

Docherty, Mary, 166

Patterson, Mary, 164

Simpson, Abigail, 163

Wilson, James, 165

public exhibition of body, 173

publicity about, 173-175

trial of, 172

Burr, C. W., 56, 157

\section{C}

Cadavers

abnormal specimens, 119

attitude of surgeons and anatomists, 272

cost of

at Vermont Medical College, Woodstock, 215

in British Isles, 119

in Paris, 107-108

demand for in British Isles, 116, 150 evaluation as property, 118

exportation from London, 151

exportation of, 126

gentlemen" resurrectionists, 118

handling of, in modern France, 107

Harrison, John Scott, as a, 239

Magrath, Corney, as a, 128

needed, United States, 254

problems, Johns Hopkins, 230

procurement of, 8

"rascal resurrectionists, 119

resurrectionists method of procurement, 121

scarcity, Edinburgh, 158

seasonal acquisition, New England, 188 secrecy

early American medical schools, 188

University of Vermont, 212

student reaction to shortage, 121

supply

after Anatomy Act (1831), 205

at

Leyden University, 110 


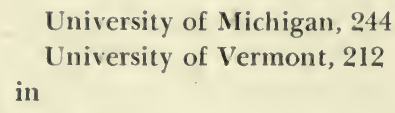

University of Michigan, 244

University of Vermont, 212 in

Austria, 111

British Isles, 116, 150

China, 113

England, 153

France, 106-107

Germany, 109

Ireland, 128-133

Japan, 113

Missouri, 254

New England, 185, 197

Renaissance, 73

Scotland, 179

United States

(1900-1958), 253

factors involved, 271-272

variations in distributions, 253

of

Vesalius, 95

Warren, John C., 200

role of undertakers in, 255

transportation of, 125

willing of bodies, 256

Cadwallader, Thomas, lecturer in anatomy, Philadelphia, 216

Caius, John, (1513-1573)

as a teacher, 135

at

Barber-Surgeons Hall, 135

Caius College, 135

Royal College of Physicians, 135

founder of anatomy, England, 134

Calvin, Jolın, French theologian, 87

Camac, C. N. B., 40

Carnegic Foundation for the Advancement of Teaching, standardization board, 247

Carpenter, C. C., 250

Carroll, Hermanus, executed criminal (1750), 222

Cassidy, Patrick, executed criminal (1788), 226

Caste system, in ancient India, 31

Castiglioni, A., 42, 43, 110

Castleton Medical College (1818-1861), 209-210 anatomical code (1824), 209

Hubbardton raid (1830), 210

Cave, A. J. E., 38

Celebration of death, 16

Celsus, 48

De Medicina, 47

writings of, 49

Cemeterics

Bully's Acre, Dublin, 129, 131

graves of paupers, source of cadavers, 188

Potter's Field, origin of term, 116

private and potter's fields, 122

Chapin, W. A. R., 210, 211, 212

Chapman, Nathaniel, adversary of Pattison, 227

Charles II, and Barber-Surgeons (1663), 137

Charles V of Spain, employer of Vesalius, 103

Chatard, J. A., 43

Cheselden, William (1688-1752), surgcon and writer, 138

China, 267

availability of cadavers, 113

medical schools, 113

ranking of medicine, 112

status of

dissection, 112, 113

legalization of dissection, 42

China, ancient

ancestral worship, 20

Buddhism, 22, 258

burial, of living humans, 21

Confucius, 21, 258

doctrine of retribution, 22

early religions of, 20-22

emperor, as ecclesiastical head, 21

hells of, 22

nature worship, 20

polytheism, 21

practical aim, of religion, 21

soul, status of, 20

tombs, building of, 21

Chovet, Abraham, anatomy teacher, Philadelphia, 219

Christ, 37 
Christianismi Restitutio (1553), Michael Servetus, 87

Chronological highlights, on dissection, 257-273

Church and dissection

Middle Ages, 58-59

Renaissance, 74

ceremonies of, 36 concern with death, 5 power in Spain, 103 separation from state, 36

Cincinnati

Cunningham, William, resurrectionist, 235-238

riot in (1852), 235

University of, resurrection, 238

Clark, E., 112, 113, 114

Clements, L. P., 249

Cleopatra, 50

Coleman, R. B., 40, 43

Columbus Medical College riot, 238

student resurrectionists (1878), 240

Columbus, Realdus (1516-1569), 81

De Re Anatomica, 81, 87

Commission on Medical Education, Final Report of the Commission on Medical Education, 247-248

Commonwealth Fund, on medical education, 247

Comrie, J. D., 154, 155, 158

Conel, J. L., 109

Confucius

his beliefs, 21

ideas on afterlife and death, 42, 258

Constantine Africanus (1010-1087), 61

Pantegni, 88

Contagion, fear of, in death, 15

Cooper, Sir Astley, 120

as a dissector, 146

post-mortem examinations, 146

relations to resurrectionists, 146-148

Cooper, B. B., 107, 147, 148

Cooper, S., 67

Cordell, E. F., 226, 230

Corner, G. W., 46, 49, 63

Correspondence ('02), 231
Correspondence ('12), 112

Correspondence ('21), 111

Council on Medical Education, standardization board, 246

Cowdry, E. V., 42, 112, 113

Cowper, William (1666-1709), British Surgeon, 138

Cremation

early method of burial, 17

in ancient India, 31

release of soul through skull, 31

Creswell, C. H., 154, 155, 156

Crimean War (1854-1856), influence on anatomy, 133, 266

Cronus, 33

Cruikshank, W. J., 59

Crummer, L., 89

Cumston, C. G., 40

Cunningham, D. J., 111, 127, 155

Cunningham, William "Old Cunny," Cincinnati resurrectionist, 235-238

\section{D}

Dana, C. L., 46

D'Argellata, Pietro, Professor at Bologna, 80

da Carpi, Berengario (1470-1550), 87

Carpi Commentaria super Anatomia Mundindi (1521), 88

Dartmouth College, organization of medical school, 185

Holmes, Oliver Wendell, 206

Davidge, John B., pioneer medical educator, 226

da Vinci, Leonardo (1452-1519), 74, 262 anatomical achievements, 79

attitude towards anatomy, 78

life of, 76 - 79

Davis, N. S., 224, 225

Dawson, W. R., 40

Dead

ancient

Chinese concepts of, 20-22

Japanese concepts of, 22

Babylonian fear of, 29

burial

ceremonies of, 14,16

positions, 17 
eating flesh of, 16

gifts to, reasons for, 18

penalties for mutilation of, 4

powers of, 13

primitive

burial of, 258

mutilation of, 13, 18

“Dead Guard Men,” New York, 225

Death

an enigma, 4

caused by sorcerer, 4,12

celebration of, 16

comparison with sleep, 9, 10

concepts, in ancient civilizations, 258

concern of Church, 5

definition of, 9

etiology of primitives, 11

fear of, 3,15

inevitability of, 9

interest to mankind, 9

mystery of, 9

primitive concepts of, $4,12,20$

relation to religion and philosophy, 9

significance of, 257

speculations on, 10

tribal sensitivities to, 14

violent, 12

DeLint, J. G., 109

della Torre, Marc Antonio (1478-1511), 78

Demand for bodies (1543-1832), 6

Demeter, 35

de Mondeville, Henry (1260-1320), 67

Demons, see Souls

Dempster, W. T., 62, 66, 79

Deniker, J., 10

De Re Anatomica (1559), Realdus Co. lumbus, 87

Dionysis, 35

Dissection

anatomy acts, of early 1800 's, 6

and Church

Middle Ages, 58

Renaissance, 74

beginning of, 106

by

Erasistratus, 49

Herophilus, 47
Ptolemy I, 47

Renaissance artists, 75

characteristics of, 106

compulsory, University of Maryland

(1833), 228

conflicts, in Renaissance, 73

dangers of infection, 178-179

decline of Alexandrian liberalism, 50

early, in New York, 222-225

emotionalism vs. rationalism, 115

evolution of, in United States, 245

executed criminals

in Scotland, 154

role of, 6

use of, 106

first

Middle Ages, 58

United States, 184

human characteristics in, 71

Holme's reaction to first, 206

importance of, 3

in

Austria, 111

China, 112

Colonial times, 182

East North Central States, 234-244

England, 134-153

France, 106-108

Germany, 108-110

Holland, 110-111

Indochina, 114

Iran, 114

Ireland, 127-133

Italy, 110

Japan, 113

Middle Atlantic States, 216-225

New England, 180

Philippine Islands, 114

Scotland, 154-179

South Atlantic States, 226-233

United States, 245-256

influence of American Revolution, 196 legalization

first, 6

in

Renaissance, 71

Venice, 87

liberality, Alexandrian school, 46 
newspaper advertising, 156

opposition to, in Illinois, 242

pioneering student dissector, Edinburgh, 158

post-Renaissance period, 6

pre-Renaissance, concepts of, 5

start of, human, 5

status

in Galen's time, liuman, 55

on Continent, in Renaissance, 71-73

student, modern France, 107

Divination, in Babylonia, 29

Dobrizhoffer, M., 14

Dobson, J., 138

Docherty, Mary, murdered by Burke and Hare, 166

Dock, W., 250

Doctor's Riot (1788), 224

Dogmatists, in pre-Alexandrian period, 41

Donatello (Donato di Niccolo di Betto Bard, 1386-1466), Miser's Heart, 75

Doolin, W., 105, 107, 127

Dreams, interpretations of, 10

Dublin

Bully's Acre, 129, 131, 266

exportation of bodies, 130

resurrection, 129

school of anatomy, 129

Trinity College, 127

Dun, Patrick, 127

Dïrer, Albrecht (1471-1519), 74, 263

Dwight, T., 207, 230

\section{$\mathbf{E}$}

East North Central States, dissection in, 234-244

Illinois, 241-243

Indiana, 243-244

Michigan, 244

Ohio, 234-241

Eber's Papyrus (1502 B.C.), anatomical information in, 27, 260

Edinburgh anatomical theatre (1697), 155

Bell, Charles, 158

Bell, John, 157
Borthwick, John, pioneering anatomy teacher, 154

Eliot, Robert, public dissector, 155 grave robbing (1711), 155

Guild of Surgeons and Barbers (1505), 154

hanging of Burke, 172

Knox, Robert, 161-179

Monro dynasty (1720-1846), 155

murders by Burke and Hare, 161-179

number of medical students (17931820), 158

Royal College of Surgeons (1694), 155 scarcity of cadavers, 158

trial of Burke, 172

Editorial (1829), 150

Editorial (1887), 153

Editorial (1894), 209

Editorial ('02), 244

Editorial ('14), 153

Edward VI (1547-1553) and human dissection, 135

Edwards, L. F., 234, 235, 236, 237, 238, 241, 242

Edwin Smith Papyrus (1600 B.C.) anotomical information in, 27, 260

Egypt, ancient

Book of the Dead, 26

death, concept of, 259

Eber's Papyrus, 27, 260

Edwin Smith Papyrus, 27, 260

immortality, concept of, 23, 25

mummification, 23, 26, 27

pioneering incisions on human corpses, 23

polytheism, 23

pyramids, 27

$\mathrm{Ra}$, god of Sun, 24

souls, 24

transmigration of souls, 25-26

Eichler, Lillian, 10

Eliot, John, suggested first medical school in United States, 184

Eliot, Robert, public dissector, Edinburgh, 155

Elizabeth I (1518-1608) and human dis. section, 135

Elliston, W. A., 142 
Elsberg, C. A., 27

Embalming

ancient Egyptian, 259

art of, pre-Alexandrian era, 38

duties of embalmer, pre-Alexandrian, 39

Warren, John C., pioneer in, 202

Emotionalism

and mob action, 120

in dissection, 115

Emperors

Charles V (1500-1558), 74

Commodus (180-192), 54

Frederick II, 62, 262

importance in ancient China, 21

Julius Caesar, deified, 36

Empirics in pre-Alexandrian period, 41

England

availability of cadavers, 152

Barber-Surgeons Company, 134

Caius, John, founder of anatomy, 134

Charles II and Barber-Surgeons, 136

Edward VI, 135

Elizabeth I, 135

Harvey, William, as an anatomist, 135-137

Henry VIII, 134

human dissection in, 134-153

Royal College of Physicians, 134

Enigmas

death, 4

man's three greatest, 4

Epicurus, 41

Epitaphs on tombs, 135

Erasistratus

Alexandrian school, 45, 260

as a dissector, 49

books of, 49

discoveries of, 49

pioneering anatomist, 46

Erinensis, 130

Eumenes of Cardia, 45

Euripides, 45

Furydice, myth of, 35

Evil, association of souls with, 12, 17, 20

Evolution

stages of, 5

survival time, 4
Executed criminals

Burke, William, 172-173

Carroll, Hermanus, 222

Cassidy, Patrick, 226

for dissection, 6

Alexandrian School, 47-48

Modern Europe and Asia, 106

Scotland, 154

obtainance procedures, 138, 140

\section{F}

Fabrica, Andreas Vesalius, 5, 6, 90, .99102, 264

criticisms of, 102

foundation for, 84

illustrations, 101

nature of text, 101

Oporinus, Johannes, printer, 99

wood blocks of, 99

Fallopius, Gabriel (1523-1562), 81

on Herophilus, 47

Fear of death, 3

Fernel, Jean, professor at University of Paris, 92, 93

Figge, F. H. J., 227, 228, 230

Firmin, Giles, first dissection in America, 184

Fisher, G. J., 45, 47, 48, 49, 52

Flexner, $\mathrm{A}$.

ideas on anatomy, 248

on medical education, 247,248

Florence

da Vinci in, 76

University of, 67

Foreign letter ('57), 153, 179

France

availability of cadavers, 106-107

handling of cadavers, 107

law (1790), 106

modern dissection, 106

student dissection, 107

Franchini, G., 81

Francis I, King of France, 70

Frank, M., 153

liranklin Medical College, Ohio, 242

Richards, George W., professor of anatomy, 242

Fraser, 1)., 108 
Frazer, J. E. S., 38

Frazer, J. G., 19

Frederick II, Emperor of Germany and two Sicilies, 62, 262

Fulton, J. F., 87

Funeral

customs, in ancient Greece, 34

directors and grave robbing, 125

\section{G}

Galen, 40, 49, 51-57, 261-262

anatomical achievements, 51, 55

education of, 52

fame of, 57

human anatomical background, 53

in

Alexandria, 53, 55

Pergamon, 53, 54

Rome, 54

influence on

Middle Ages, 58

Renaissance, 71

parents of, 52

personality of, 56

physician, to gladiators, 53

place of birth, 51

reactions to anatomical architecture, 56

religion, 56

status of human dissections, 55

style of writing, 56

Gardner, E., 253, 254

Garrison, F. H., 105, 109, 114

Gask, G. E., 46

Genesis of ancient religions, 20

Geraughty, Tom, Irish resurrectionist, 131

Germany

anatomical laws, 109

availability of cadavers, 109

Brunner, John C., 108

modern dissection in, 108-110

number of medical students, 109

teachers, 109

Ghosts, see Soul

Gnosticism, philosophic-religious, 44
Gods

and magic, in Babylonia, 28

mythological, 20

power of, in ancient Greece, 34

propitiation of Babylonia, 28

sacrifices to, in ancient Greece, 33

Gordon, B. L., 42

Grave robbers, see Resurrectionists

Grave robbing

as a trade, 6

Berkshire Medical College, 209

funeral directors, 125

in

Dublin, 129

Edinburgh, 155

Great Britain, 264

Indiana, 243

Ohio, 234

United States, 269

Virginia, 232

materials needed, New England, 187

preventive measures, 186

reaction of populace, 122

safeguards against, 124

seasonal factor, 126

student resurrectionists, Ohio, 239

technique of, New England, 187

University of Cincinnati, 238

Vermont Medical College at Woodstock, 213

Gravestones

of Paleolithic man, 17

significance of, 17

Greece, ancient

Achilles, 34

Apollo, 34, 35

concepts of death, 259

Cronus, 33

funeral

celebration, sports, 34

pyres, 34

Hades, 34

Hector, 34

Iliad, 33

immortality, 34

Mount Olympus, 33

Mythology, 35

nature gods, 33 
Orphic

doctrine, 35

hell, 35

polytheism, 33

power of gods, 34

sacrifices to gods, 33

Styx, river of Hades, 33

Trojan War, 34

Zeus, 33

Green, R. M., 55

Gregg, A., 249

Gross, Samuel D., surgeon, as resurrectionist, 222

Guild, influence of, 116

Guild of Surgeons and Barbers (1505), Edinburgh, 154

Guinterius, Joannes (1478-1574), 92

Guttmacher, A. F., 42, 107, 111, 117, $118,125,129,130,134,135,138,140$, $142,143,144,145,147,148,149,150$, $152,153,154,157,160,161,165,167$, 172,230

\section{$\mathbf{H}$}

Habitat of soul, primitive concepts, 14

Hades, 34

Haggard, H. W., 38, 42, 43, 46, 157, 243

Hammett, F. S., 43

Hare, William, Edinburgh 'murderer, $161-179,265$

McDougal, Helen, accomplice, 166 murder of

Docherty, Mary, 166

Patterson, Mary, 164

Simpson, Abigail, 163

Wilson, James, 165

post-trial life, 173

publicity about, 173-175

trial of, 172

Harrington, T. F., 105, 107, 191, 193, $194,198,205$

Harris, I). F., 112

Harrison, John Scott, as a cadaver, 239

Hartwell, E. M., 183, 184, 194, 217, 218, $222,225,231$

Harvard Medical School ('06), 194
Harvard Medical School, 191-209

Holmes, Oliver Wendell, 206-209

La Terriere, 197

organization of (1782), 191

students as resurrectionists, 200-202

Warren, John, 191-198

Warren, John C., 198-203

Harvey, William (1578-1657), 135-137

Hawkins, Caesar, 117

Heaven, in ancient India, 31

Hebrus, 35

Hector, 34

Hells

of ancient

China, 22

India, 30

distance to, 32

messengers of, 31

number of, 31

Japan, 23

Hemmeter, J. C., 87

Henry IV, King of France (1553-1610), 82

Henry VIII and dissection, 134

Henry, G. W., 59, 69, 70

Herophilus

Alexandrian School, 45, 260

Father of Anatomy, 47

nature of studies, 48

number of cadavers dissected, 47

pioneering

anatomist, 46

pathologist, 47

vivisectionist?, 47

Herringham, W., 136

Heyl, Erwin, gentleman resurrectionist (1878), 240

Hinduism

in ancient India, 30, 31, 259

medicine, Susruta, 42

Vedas, 42

Holland, 267

Ruysch, Frederick, 111

status of dissection in, 110-111

Holmes, Oliver Wendell (1809-1894)

as an anatomist, 206-209

at

Dartmouth (1838-1840), 206 
Harvard Medical School, 206

examinations given by, 207

in

Paris, 107, 206

retirement, 208

obituary, 209

personality, 206

reaction to first dissection, 206

Holy Land, pilgrimage of Vesalius, 104

Homer, Iliad, 33, 259

Horner, William Edmonds (1793-1853) professor of anatomy, University of Pennsylvania, 220

Hospital medical schools, London, 149

House of Commons investigation of dissection laws (1828), 151

select committee of, 151

Human bodies

complexity of, 272

demand for (1543-1832), 6

mummification, ancient Egypt, 23

parts used for magic, 183

penalties for mutilation of, 4

primitive mutilation of, 13,18

procurement of cadavers, 8

start of dissection, 5

Humanism in European Renaissance, 68

Hume, E. E., 112

Hume, E. H., 42

Hundt, Magnus, Antropologium, 88

Hunter, John (1728-1793)

as a teacher, 142

Hunterian Museum, 142

Irishman O'Brien, 142

portrait by Sir Joshua Reynolds, 144

Hunter, William (1718-1783), 117

achievements of, 142

as a teacher, 142

school of anatomy, 140

Hunter, William, of Rhode Island, 184

\section{I}

Ignatius Loyola, 96

Illinois

anatomy law (1885), 242

dissection in, 241-243

Franklin Medical College, 242
Jacksonville riot (1848), 242

medical department, Illinois College, 242

number of medical schools, 241

opposition to dissection, 242

Illinois College, Medical Department of, 242

Illustrations, anatomical

Fabrica, 101

five figure series, 89

fugitive sheets, 89

Hundt's Antropologium, 88

of Renaissance, 88-89

Peyligk's Philosophiae Naturalis, 88

Phryesen's, Spiegel der Artzny, 88

van Calcar, Jan Stephan, 97

Image in water, importance, 10

Immortality

belief in, 10

ancient

Egypt, 23, 25

Greece, 34

India, 30

Japan, 23

of bodily parts, 25

primitive concepts of, 4

India, ancient

Aryans, 30

black magic, 30

Brahmanism, 30

burial procedure, standards of, 32

carion fly, 32

caste system, 31

cremation, 31

distance to hell, 32

heaven, 31

Hinduism, 30, 31

immortality, 30

messengers of hell, 31

nature worship, 29

polytheism, 30

priest's administrations to dying, 32

retribution, 30

souls in, 30

Tower of Silence, 32, 114

transmigration of souls, 31

Yama, 31

Zoroastrianism, 32 
Indiana

anatomical law (1879), 243

dissection in, 243-244

grave robbing (1879), 243

number of medical schools, 243

Indochina, status of dissection, 114, 268

Inquisition of Vesalius, 103-104

Integration of anatomy, 7

Intellectual ages of man, 4

Interpretations of

(lreams, 10

image in water, 10

shadow, 10

Iran, 267

status of dissection, 114

Tower of Silence, 32, 114

Ireland, 266, see also Dublin

Dun, Patrick, 127

Geraughty, Tom, 131

human dissection in, 127-133

Magrath, Corney, 128

Molyneux, Thomas, 127

Rae, Wilson, resurrectionist, 130

Trinity College, Dublin, early dissection, 127

Irishman O'Brien, giant, competition for body of, 142

Isis

Egyptian deity, 25

in ancient Roman religion, 37

Italy

status of dissection in, 110

training of anatomists, 115

\section{J}

Janssen, Baltimore resurrectionist, 23

Japan, 268

cadaver availability, 113

medical schools, 113

status of dissection, 113

teachers, 113

Japan, ancient, 22-23

belief in immortality, 23

burial

of living humans, 23

procedures in, 29

concept of hell, 23 polytheism, 22

primitive Shintoism, 22

reaction to dead, 22

tombs in, 23

Jenkins, G. B., 252, 253

Johns Hopkins Medical School, cadlaver problem, Mall, Franklin P., 230

Johnson, C. B., 244

Johnson, V., 250

Jonas, H. C., 40

Julius Caesar, deified emperor, 36 burning Alexandrian school, 50

\section{$\mathbf{K}$}

Kelly, H. A., 230

Kempf, E. J., 38

Kerr, A. T., 111

Khairallah, A. A., 43

Kings

Charles II and Barber-Surgeon's, 136 Charles V of Spain, 103

Francis I of France, 70

Henry IV of France, 82

Louis D'Anjou of France, 81

Maximilian of Rome, 70

Philip of Spain, 103

King, H. D., 134

Knox, J. H. M., 206

Knox, Robert, 265

and Wakley, Thomas, 171

as a teacher, 167-I68

defamation of, 168

early training, 167

Edinburgh anatomist, 161-179

in comparison with Macartney, 131

inquest of, 175-177

later life, 177-179

mob action, 168

physical characteristics, 167

Simpson, Abigail, murdered, 164

student attendance in classes, 168

Korns, H. M., 88, 111

Kraemer, Heinrich, The Wilches Hammer, 69

Krumbhaar, E. B., 184, 223, 231 
$\mathbf{L}$

Ladenheim, J. C., 222, 224, 225

La Terriere, student, Harvard Medical School (1788-1789), 197

Laurie, S. S., 63

Lees, Andrew, Edinburgh resurrectionist, 160-161

Legalization of dissection

first, 6

in

Middle Ages, 58

Renaissance, 71

Venice, 87

status, in China, 42

Warburton Anatomy Act (1832), 153

Leidy, Joseph (1823-1891) professor of anatomy, University of Pennsylvania, 221

Lerida, University of, 67

Levy-Bruhl, L., 11

Leyden University, cadaver supply, 110

Liston, Robert (1794-1847), as a resurrectionist, $158-159$

London

Bishop, May and Williams, murderers, 152

exportation of cadavers, 151

number of medical students (1828), 150

Lonsdale, H., 111, 149, 155, 156, 167, $170,171,174,175,178,179$

Lycos, 49 -

M

Macalister, A., 127, 128, 129, 131, 132, $133,135,138,139$

Macartney, James, professor of anatomy, Trinity College, 130-131

MacCallum, W. G., 83

Mackenzie, W. M., 107

Macmichael, W., 135

Madrid, Vesalius in, 103

Magic

and religion combined, 29

black, in ancient India, 30

in

Babylonia, 28

Middle Ages, 59 parts of body used for, 183

status in pre-Alexandrian era, 38

Magrath, Corney, human giant, 128

Major, R. H., 109

Mall, Franklin P., 230, 246

cadaver problem, Johns Hopkins, 230

Malloch, A., 57

Man

architecture of, 3

intellectual ages of, 4

Marcus Aurelius Antonius (Caracalla),

Alexandrian school, 50

Marinos, 49

Mark Antony, 50

Maryland, see also Baltimore and University of Maryland

Anatomy acts of

(1832), 230

(1882), 230

(1890), 230

(1938 revision), 230

(1949 revision), 230

Massachusetts

Anatomy Acts

English Act of 1604, 183

evolution of Act of 1831, 204, 206

Law of 1660, 183

Resolution of 1647,183

Berkshire Medical College, 209

Harvard Medical School, 191-209

“The Body of Liberties," 182

Maximilian, King of Rome, 70

May, London murderer, 152, 265

McDougal, Helen

accomplice of Burke and Hare, 166

emigration to Australia, 173

McGuire, S., 232

McMurrich, J. P., 79, 81, 88

Medical Schools

closure in British Isles (1829), 150

in

China, 113

Japan, 113

London, 150

New England, 191-215

United States (1900-1958), 245

number in

Illinois, 241 
Indiana, 243

Michigan, 244

Ohio, 234

United States, 180-181, 268-269

organization in New England, 185

reduction in number in United States,

252,271

regional considerations, 181-182

secrecy with cadavers, 188

tradition of oldest, in United States, 181

Medical students

as resurrectionists, 156

Columbus Medical College (1878), 240

Ohio, 239

University of Vermont, 211

at University of Michigan, 244

colonial students in Europe, 185

compulsory dissection, University of

Maryland (1833), 228 -

dissecting in British Isles, 134

increase in United States, 252, 271

number in

Austria, 111

Edinburgh (1793-1820), 158

Germany, 109

London (1828), 150

of

Robert Knox, 168

William Shippen, 218

pioneering dissectors, 158

reaction to cadaver shortages, 121

Vermont graduates (1820-1840), 211

Medicine

problems in United States, 180

progress in, 3

ranking of, in China, 112

renaissance of, 5

superstition in, 8

Metchnikoff, E., 9

Mettler, Cecelia, C., 142, 220

Meyer, A. W., 255

Meyer, W., 110

Michelangelo (1475-1564), 74, 263

Michigan, dissection in, 244 number of medical schools, 244

University of, 244

Middle Ages, 58-67, 260

Alexandrian fire, 2nd Century, 58

Arabian influence, 61-62

astrology, influence, 60

Avicenna, 58

characteristics of, 58

church and dissection, 58, 59

de Mondeville, Henry, 67

first human dissections, 58

Galenic influence, 58

hostility to science, 60

legalization of dissection, 58

magic, 59

Mondino da Luzzi, 63-66

psychological atmosphere, 59

Theodosian Code, 59

time interval, 58

universities of, $62-67$

Middle Atlantic States

Cadwallader, Thomas, 216

dissection in, 216-225

Shippen, William, Jr., 216

University of Pennsylvania, 216-222

Middleton, W. S., 217, 218, 219, 220, 221. 222

Milan, da Vinci in, 78

Miller, W. S., 219, 228

Miscellany (1894), 207

Miser's Heart, anatomical painting by Donatello, Renaissance, 75

Mithras, 37

Molyneux, Thomas, 127

Mondino da Luzzi (1276-1326), 63-66, 262

Monros, Alexander, I, II and III dynasty of (1720-1846), 155

Monro I

innovations in teaching, 156

subjected to mob violence, 156

Monro II, as a teacher, 157

Monro III

as a teacher, 158

Burke case, 172

Montagu, M. F. A., 85

Montpellier

de Mondeville, Heury, 67 
Kings

Henry IV, 82

Louis D'Anjou, 81

Rabelais, 81

University of, $66,81-83$

Moore, G. F., 18, 22, 23, 25, 29, 33, 36, 37

Morgan, John

and William Shippen, Jr., 217, 219

ideas on anatomy, 217

Mount Olympus, 33

Mummification

first incisions, 23

in

ancient Egypt, 23, 26, 27, 260

pre-Alexandrian era, 38,260

relation to Osirian myth, 25

Murder

by

Bishop, May and Williams, 152

Burke and Hare, 161-179

resurrectionists, 6

Waldie, Jean and Torrence, Helen, 157

of

Brown, Emily, 228-230

Docherty, Mary, 166

Patterson, Mary, 164

Simpson, Abigail, 163

Wilson, James, 165

Museum

anatomical and pathological, in British Isles, 119

at Alexandrian school, 45

Hunterian, 142

Mutilation of bodies

penalties for, 4

primitive, 13,18

Mystery of death, 9

Mythology in

ancient

Egypt

Anubis, 25

Isis, 25

Osiris, 25

Ra, sun god, 24

Set, 24

\section{Greece}

Apollo, 34, 35

Demeter, 35

Dionysis, 35

Eurydice, myth of, 35

Hebrus, 35

Orpheus, myth of, 35

Orphic

doctrine, 35

hell, 35

Thrace, women of, 35

Roman religion

Attis, 37

Isis, 37

Mithras, 37

pre-Alexandrian anatomy, 39

relation to certain gods, 20

\section{$\mathbf{N}$}

Naples, University of, 67

National board, standards in anatomy, 249,270

Nature

gods of, in ancient

China, 20

Japan, 22

worship in ancient

Babylonia, 28

Greece, 33

India, 29

Rome, 36

Neanderthal man, burial procedure, 16

New England

anatomical laws, 182-186

cadaver supply, 185, 197

Dartmouth College, 185

early dissection in, 180-215

efficiency of anatomy laws, 186

grave robbing, 187-188

medical schools

number in, 191-215

organization of, 185

New Hampshire, anatomy law (1796), 185

New York

anatomy act (1789), 225

"Dead Guard Men," 225

Doctor's Riot (1788), 224 
carly dissection in, $222-225$

opposition to dissection in, 223

Thomas Wood, anatomy notice, 223

Norwood, W. F., 194, 209, 218

Nourse, Edward, 117

\section{O}

\section{Ohio}

anatomical laws (1831, 1840, 1879, $1880,1881) 234,235,240,241$

Columbus Medical College, riot, 238

dissection in, 234-241

grave robbing (1811), 234

Harrison, John Scott, 239

Heyl, Erwin, resurrectionist (1879), 240

mob riot (1811), 234

number of medical schools, 234

Painesville resolution (1845), 235

public notice, newspaper (1878), 241

riot, in Cincinnati (1852), 235

Willoughby Medical College (Ohio State), 235

Worthington Medical College, 234

Old Testament, Hebrew anatomical antipathy, 42

O'Malley, C. D., 105

Oporinus, Johannes, printer of Vesalius' Fabrica, 99

Orpheus

doctrine, 35

hell, 35

myth of, 35

Osiris

Egyptian deity, 25

relation to mummification, 25

Osler, W., 40, 42, 87, 107, 108

Overholser, M. D., 254

\section{P}

P'ackard, F. R., 63, 142, 217

Padua

Columbus, Realclus, 81

da Carpi, Berengario, 87

Fallopius, Gabriel, 81

University of, 71, 81
Vesalius

as a teacher, 97

in Padua, 95-99, 102

Paleolithic man, gravestones of, 17

Pantegni, Constantine's (1070), 88

Paris

Fernel, Jean, 92, 93

Guinterius, Joannes, 92

Holmes, Oliver Wendell, 107, 206

Servetus, Michael, 85-87

Sylvius, Jacobus, 83-85, 92, 94

training of anatomists, 115

University of, 83

Vesalius in, 92-95

Park, R., 54

Parmenides, 41

Parrish, Joseph, student, University of Pennsylvania, 220

Patrick, resurrectionist, 148

Patterson, Mary murdered by Burke and Hare, 164

Stevenson, R. L., The Body Snatchers, 165

Pattison, Granville Sharp, University of Maryland, 227

Peirson, Abel L., influence in Anatomy Act of 1831, 204

Pergamon

Asklepieion, 51

Galen, 51, 53, 54

library of, 50

Peyligk, John, Philosophiae Naturalis, 88

Philip of Spain, employer of Vesalius, 103

Philippine Islands, status of dissection, 114

Philosophine Naturalis (1499), John Peyligk's, 88

Philosophy, relation to death, 9

Phryesen's Laurentius, spiegel der Artzny, 88

Pilcher, L. S., 60

Pisa, Vesalius at University of, 102

Plato, 41

Pollaiuolo, Antonio (1429-1498), 74 
Polytheism, ancient

Babylonia, 28

China, 21

Egypt, 23

Greece, 33

India, 30

Japan, 22

Rome, 36

Pontifex Maximus, 42

Popes

Alexander V, 80

Benedict XIV (1675-1758), 80

Clement VII (1478-1534), 74

Innocent VIII, Papal Bull, 70

Sixtus IV (1414-1484), 74

Pott, Percival, 117

Potter's Field

origin of term, 116

source of cadavers, 188

Prague, University of, 67

Praxagoras, 40

Pre-Alexandrian anatomy, 38-43 anatomical

antipathy, 40

terminology, 39

Arabian beliefs, 43

art of embalming, 38

beliefs, of Pythagoras, 41

characteristics of organs, 39

duties of embalmer, 39

Epicurus, 41

fear of souls, 41

Hebrew anatomy, 42

in Talmud, 43

magic, status of, 38

nummification, 38

mythoiogical anatomy, 39

Parmenides, philosophy of, 41

Plato, philosophy of, 41

Pontifex Maximus, 42

School of

Dogmatists, 41

Empirics, 41

status of anatomy, 38, 39

Stoics, 41

taboos on corpse, 42

Xenophanes, monotheism, 41
Prendergast, J. S., 57

Priests

administration to dying, India, 32

in ancient

Babylonia, 29

Brahmanism, 30

Roman religions, 36

of Asklepios, influence of, 40

Primitive concepts of

death, 4,20

etiology of death, 11

immortality, 4

reincarnation, 18

retribution, 20

soul, 4, 20

Profits, of resurrectionists, 6

Ptolemy I (Soter)

as a dissector, 47

governor of Egypt, 45

Public notices

Ohio newspaper (1878), 241

Thomas Wood, 223

William Shippen, Jr., 218

Pyramids in Ancient Egypt, significance of, 27

Pythagoras, 41

\section{Q}

Quintos, 49

\section{$\mathbf{R}$}

Ra, Egyptian sun god, 24

Rabelais, 81

Rae, Wilson, Dublin resurrectionist, 130

Ranke, H., 28

Rationalism in dissection, 115

Reincarnation, primitive concepts of, 18,258

Reisner, G. A., 27

Religion

Brahmanism in ancient India, 30

Calvin, John, 87

combined with magic, 29

early Chinese, $20-22$

genesis of ancient, 20

Hinduism in ancient India, 30

Ignatius Loyola, 96 
of Galen, 56

practical aim in ancient China, 21

priests in ancient Roman, 36

relation to death, 9

Theatin monks, 96

Renaissance, European (1350-1650), 6889,262

anatomical

illustrations, 88-89

role of artists, $74-79$

theatres, 71

anatomists

Achillini, Alessandro, 80

Columbus, Realdus, 81, 87

da Carpi, Berengario, 87, 88

D'Argellata, Pietro, 80

della Torre, Marc Antonio, 78

Fallopius, Gabriel, 81

Servetus, Michael, 85-87

Sylvius, Jacobus, 83-85

Willis, Thomas, 70

artists

da Vinci, Leonardo, 74, 76-79

Donatello, 74

Dürer, Albrecht, 74

Michelangelo, 74

Pollaiuolo, Antonio, 74

Titian, 74

Verrocchio, Andrea, 75

availability of cadavers, 73

Black Plague, 70

Calvin, John, 87

characteristics of, 68

Church and dissection, 74

dissection conflicts, 73

Emperor Charles V, 74

human dissection, characteristics, 71

humanism, 68

importance of, 68

influence of

Avicenna, 71

Galen, 71

kings

Francis $I, 70$

Henry IV, 82

Iouis I'Anjou, 81

Maximilian, 70 legalization of dissection, 71

mind of, $69-70$

Popes

Alexander V, 80

Benedict XIV, 80

Clement VII, 74

Innocent VIII, 70

Rabelais, 81

Sixtus IV, 74

status of human dissection, 71-73

universities, $79-88$

Renaissance of medicine, 5

Report of Council on Medical Education ('06), 247

Report of Third Teaching Institute ('56), 255

Report to.American Surgical and Dental Associations, 247, 251

Resurrection, see Grave robbing

Resurrectionists

and teachers, 120

apprehended, 120

connivance with surgeon-anatomists, 120

dealings with Sir Astley Cooper, 146, 148

deception of, 124

ethics of, 122

fees of, 12,125

"gentlemen" resurrectionists, 118

Gross, Samuel D., surgeon, 222

Heyl, Erwin, Ohio, 240

La Terriere, 197

Liston, Robert, 158-159

medical students, 156

Columbus Medical College (1878), 240

Harvard Medical School, 200-202

in Ohio, 239

University of Vermont, 211

Sewall, Thomas, 189, 204

Warren, John C., 198-199

in

Great Britain, 265

United States, 269

law of supply and demand, 119

methods of cadaver procurement, 121 
murder and, 6

professional

Cunningham, William, 235-238

Geraughty, Tom, 131

Janssen, 231

Lees, Andrew, 160-161

Patrick, 148

Rae, Wilson, 130

profits of, 6

"rascal" resurrectionists, 119

regard to cadaver habiliment, 118

reputation, 6

rise of, 115-126

sale of teeth, 125-126

Retribution

doctrine of, ancient China, 22

first concepts of, 20

in ancient India, 30

in Babylonia, 29

Reynolds, Sir Joshua, painting of John Hunter, 144

Rhazes (850-923), 61

Rhode Island

Hunter, William, 184

statute (1655), 183

Richards, George W., professor of anatomy, Franklin Medical College, 242

Riots

against Robert Knox, 168

and emotionalism, 120

Baltimore (1788), 226

Cincinnati (1852), 235

Columbus Medical College, 238

Doctor's Riot (1788), 224

Hubbardton Raid (1830), 210

inciting factors, 126

in United States, 7, 270

Jacksonville, Illinois (1848), 242

Monro I (1725), 156

Ohio (1811), 234

Sailors' Mob (1765), 217-218

Robinson, G. C., 135, 137

Robinson, Robert, professor of anatomy, Trinity College, 128

Rohrer, C. W. G., 142, 222
Rolf, John, Cambridge professor (1707), 137

Rolleston, H., 138, 139, 142, 144

Romans, ancient, 36-37

Attis, 37

Christ, 37

church ceremonies, 36

concept of dead, 259

Isis, 37

Julius Caesar, deified emperor, 36

Mithras, 37

nature, 36

nether world, 36

polytheism, 36

priests, 36

separation of church and state, 36

Rome

da Vinci in, 78

fire (A.D. 192), 54

Galen in, 54

Maximilian, King, 70

Royal College of Physicians

anatomical theatre, 135

Caius, John, 135

first charter, 134

Royal College of Surgeons

by law (1824), 150

Edinburgh (1694), 155

Ruysch, Frederick (1683-1731), Holland, 111

\section{S}

Sabin, Florence R., 185, 230

Sack-em-up men, see Resurrectionists

St. Bartholomew's, London, beginning medical school, 139

St. Thomas Hospital, London, 138

Salerno, University of, 62

Sarton, G., 57

Satyros, early famous anatomist, 53

Saunders, J. B. deC. M., 105

Schools of

anatomy

Dublin (1784), 129

Hunter's, 140

private in Dublin (1865-1900), 132

Dogmatists, 41

Empirics, 41 
Science, hostility towards, in Middle Ages, 60

Scotland

anatomical laws, 154

cadaver supply, 179

executed criminals, for dissection, 154

human dissection in, 154-179

traditions in anatomy, 154

Seraphium, at Alexandrian School, 45

Servetus, Michael (1511-1553), 85-87, 264

Apology to Astrology, 86

Christianismi Restitutio, 87

Set, Egyptian deity, 24

Sewall, Thomas, early "gentleman" resurrectionist, 189, 204

Shadow, interpretation of, 10

Shamanism, see Magic

Shintoism, in ancient Japan, 22, 258

Shippen, William, Jr. (1736-1808)

advertisement of lectures, 218

and John Morgan, 217, 219

at Surgeon's Hall, Philadelphia, 218

class attendance, 218

Professor of Anatomy, University of Pennsylvania, 216

Sailors' Mob, 217

Sigerist, H. E., 39, 111

Simpson, Abigail, murdered by Burke and Hare, 163-164

Singer, C., 38, 48, 80, 83, 88, 110

Sleep, comparison with death, 9,10

Sophacles, 45

Sorcerer, as cause of death, 11

Souls

ancestral worship of, 14

association with evil, 12, 17, 20, 30

defensive measures against, 15

evaluation of, 257

evil, in Babylonia, 28

first concepts of, 4, 10-11, 20

good and bad, 4

habitat in Babylonia, 29

in

ancient

Figypt, 24

India, 30

Middle Ages, 262 indwelling, 10, 11

nether world, ancient Romans, 36

powers of, 13

pre-Alexandrian, fear of, 41

primitive habitat of, 14

status, in ancient China, 20

transmigration in ancient

Egypt, 25-26

India, 31

types in ancient China, 21

South, J. F., 134, 135, 137, 139

South Atlantic States

Cassidy, Patrick, executed criminal, 226

Davidge, John B., pioneer medical educator, 226

dissection in, 226-233

Baltimore, 226

Virginia, 231-233

Mob riot, Baltimore (1788), 226

Pattison, Granville S., 227

University of Maryland, 226-230

Washington, D.C., 230-231

Wiesenthal, C. F., early dissector, 226

Spain, power of Church, 103

Special feature article ('55), 256

Specialty boards, standards in anatomy, 249

Speculations, on death, 10

Spiegel der Artzny, Laurentius Phryesen (1518), 88

Spirit, see Soul

Sprenger, Johamn, The Witches Hammer, 69

Sprigge, S. S., 150

Standardization boards

American Medical Association, 7, 246 . 247

Association American Medical Colleges, 247

Carnegie Foundation for the Advancement of 'Teaching, 247

Commission on Medical Education, 247.248

in

Great Britain, 117, 264

United States, 246-250

National Board, 247-249 
Specialty Boards, 247-249

State Boards, 247, 249

State Boards, standards in anatomy, 247, 249

Stevenson, Robert Louis, The Body Snatchers, 165

Stoics, 41

Streeter, E. C., 79

Styx, river of Hades, 33

Superstition

in medicine, 8

of dead, 3

Surgeon-Anatomists

Cheselden, William, 138

connivance with resurrectionists, 120

Cooper, Sir Astley, 120, 146-148

Cowper, William, 138

Hawkins, Caesar, 117

Hunter, William, 117

in Great Britain, 115

Nourse, Edward, 117

Pott, Percival, 117

Susruta, Hindu medical text, 42, 260

Sylvius, Jacobus (Jacques Dubois, 1478 1555), 83-85, 92, 94, 263

\section{$\mathbf{T}$}

Tabulae Anatomicae, Andreas Vesalius, 99

Talmud, anatomy in, 43

Taylor, H. O., 38

Teaching Institute, in Anatomy and Anthropology ('55), 255

Teachers

and resurrectionists, 120

Bell, Charles, 158

Caius, John, 135

in

Germany, 109

Japan, 113

Renaissance, 263

Knox, Robert, 167-168

Monros, Alexander, 157, 158

Warren, John, 195

Teeth, sale of, 125-126

Tertullian, charge against Herophilus, 48
Theatin monks, encouraged anatomical studies, 96

"The Body of Liberties" (1641), Massachusetts anatomy law, 182

Theodosian Code (A.D. 420), 59

The Witches Hammer, Sprenger, J., and Kraemer, H., 69

Thrace, women of, 35

Tilton, Eleanor M., 206, 207

Titian (Tiziano Vecellio, 1477-1576), 74, 263

Vesalius' artist?, 101

Tombs

building of, in ancient

China, 21

Egypt, 27

Japan, 23

epitaphs on, 135

Toner, J., 185

Torrence, Helen, murderess, 157

Tower of Silence, 32, 114

Transmigration of souls

in ancient

Egypt, 25-26

India, 31

Tribal, sensitivity to death, 14

Trinity College, Dublin

anatomical theatre, 127

chair of anatomy (1710), 127

early dissection, 127

Macartney, James, 130-131

Robinson, Robert, professor of anatomy, 128

Trojan War, 34

Turner, E. D., 252

\section{$\mathbf{U}$}

Undertakers, role of, 255

United States

anatomical

laws, 252, 254

problems, 268

teaching, 245-256

prior to $1900,245-246$

competition of medical schools, 246

number of medical schools, 246 
research, 246

status of dissection, 245

teaching hours, 246

$1900-1958$

changes in, 270

criticism of, 250,270

essentials for, 249

importance, 248

improvement, 250

knowledge for boards, 249

medical schools, 245, 268, 271

number of, 180-181

place in curriculum, 248

significance of research, 249

standardization boards, 246-256

students, increase in, 252

teaching hours, 248, 252

Teaching Instifute in Anatomy and Anthropology ("55), 255

cadavers

needed, 254

supply, 253, 254, 271

variations in distribution, 253

dissection

evolution of, 245

status (1900-1958), 245-256

grave robbing, 269

medical problems in, 180

riots, 7,270

undertakers, role in cadaver supply, 255

willing of bodies, 256

Universities of

Middle Ages, 62-67, 262

Renaissance, 79-88

University of

Bologna, 63-66, 79-80

Cambridge, 139

Cincinnati, 238

Florence, 67

Harvard, 191-209

Lerida, 67

Leyden, 110

Maryland, 226-230

compulsory dissection (1833), 228

Davidge, John B., 226

Pattison, Granville S., 227
Michigan, 244

cadaver supply, 244

students enrolled, 244

Montpellier, 66

Naples, 67

Padua, 71, 81, 95-99

Paris, 83

Pennsylvania, 216-222

Horner, William E., 220

Leidy, Joseph, 221

Morgan, John, 217

Parrish, Joseph, 220

pioneering anatomy course in America, 216

Shippen, William Jr., 216

Wistar, Caspar, 220

Prague, 67

Salerno, 62

Venice, 67

Vermont

anatomical

fee (1825), 211

laws, 210

founding of, 210

secrecy in handling cadavers, 212

student resurrectionists, 211

supply of cadavers (1882), 212

\section{V}

van Calcar, Jan Stephan, artist, 97

Fabrica, 99

Vedas, Hindu writings, 42

Venice

legalization of dissection, 87

University of, 67

Vesalius, 96

Vermont

anatomical laws

(1804), 186

(1870), 210

(1884), 210

Castleton Medical College, 209-210 medical graduates (1820-1840), 211 University of Vermont, 210-212

Vermont Medical College at Woodstock, 213.215 
Vermont Medical College at Woodstock (1827-1856), 213-215

Verrocchio, Andrea (1435-1488), 75, 76, 78

Vesalius, Andreas, 5, 90-105, 264

achievements of, 90

as a

dissector, 94

teacher, 97

at

Bologna, 102

University of

Padua, 81, 95-99, 102

Pisa, 102

availability of cadavers to, 96

Charles V of Spain, 103

death of, 104

early life, 91-92

Fabrica, 5, 90, 99-102

foundation for Fabrica, 84

Ignatius Loyola, relation to, 96

in

Madrid, 103

Paris, 92-95

Venice, 96

Inquisition, 103-104

personality, 104-105

Philip of Spain, 103

pilgrimage to Holy Land, 104

stature of, 90

Theatin monks, 96

van Cälcar, Jan Stephan, 97, 99

Vienna, anatomical theatre, 111

Viets, H. R., 110, 184

Virginia

dissection in, 231-233

grave robbing, 232

Warner, Augustus L., pioneering anatomist, 231

Vivisection

accusation against Herophilus, 47

\section{W}

Waite, F. C., 183, 184, 186, 188, 189, 197, 204, 205, 210, 211, 213, 214, 215

Wakley T., 144, 150

and Robert Knox, 171
Waldie, Jean, murderess, 157

Walsh, J., 46, 49, 59, 74

Walton, G. I., 109

Warbasse, J. P., 56

Warburton Anatomy Act (1832), 153, 266

Warner, Augustus L., pioneering anatomist, Virginia, 231

Warren, E., 191, 195, 196, 199, 202

Warren, John (1753-1815), Harvard professor of anatomy, 191-198

as

a teacher, 195

an organizer, 191

personality of, 195

stature among contemporaries, 191

Warren, John Collins, Harvard professor of anatomy

anatomical activities, 198

as a

dissector, 202

"gentleman" resurrectionist, 198

cadaver availability, 200

education, 198

personality of, 198, 203

pioneering embalmer, 202

Washington, D.C., 230-231

anatomical board (1902), 231

influence of Civil War, 231

status of dissection in, 230

Watson, B. P., 154, 155, 156, 159

Weaver, G. H., 242

Weaver, J. C., 45

Weiskotten, H. G., on medical education, 247, 249

Welch, W. H., 105

Whipple, A. O., 249

Wiedermann, A., 27

Wiesenthal, C. F., Baltimore

Cassidy, Patrick, executed criminal, 226

dissector (1788), 226

mob riot (1788), 226

Williams, London murderer, 152

Willing of bodies, 256

Willis, Thomas (1621-1675), 70 
Willoughby Medical College (Ohio Worthington Medical College of Ohio State), 235

Wilson, James ("Daft Jamie"), murdered by Burke and Hare, 165

Winchester Medical College (1826-1861), 232

Brown, Owen, body of, 232

Wistar, Caspar

professor of anatomy, University of Peunsylvania, 220

Wood, C. T., 44

Wood, Thomas, public notice of anatomy lectures, 223

Woodburne, R. T., 253, 254

Worship

in ancient China

ancestral, 20

nature, 20

(1831-1939), 234

Wright, J., 38

\section{$\mathbf{x}$}

Xenophanes, 41

\section{Y}

Yama, judge of souls, ancient India, 31

Yesko, S. A., 47

\section{Z}

Zeus, 33

Zilborg, G., 59, 69, 70

Zoroaster, 32

\%oroastrianism

in ancient India, 32

reactions to dead, 33

Tower of Silence, 32, 114

Zoroaster, 32 




\section{SOME OTHER TITLES IN THIS FIELD}

THE PYRAMIDAL TRACT: Its Status in Medicine. By Arthur M. Lassek, Boston Univ. FOR READY REFERENCE: A Chronological Outline is presented which gives the salient facts of pertinent investigations in the field - on man in one group - and on subhuman mammals in a second. Pub. '55, 160 pp., (Amer. Lec. Anatomy), Cloth, $\$ 4.75$

THE HUMAN BRAIN: FROM PRIMITIVE TO MODERN. BY A. M. Lassek. Provides basic, factual and inferential material for those interested in the striking structural and physiological changes which have occurred in this important organduring man's remote past. Considers such questions as: Problems of earliest man, structural growth of the human brain, balancing the sensations, the development of skilled movements and the evolution of the mind. Pub. '57, 232 pp., 3 il., Cloth, $\$ 4.75$

AN INTRODUCTION TO FUNCTIONAL ANATOMY. BY D. C. Sinclair, Univ. Western Australia. Topography is considered regionally and general anatomy and function systematically: there is a section on the integration of physiological responses with special reference to muscular exercise. Pub. '57, 426 pp., 80 il., Cloth, $\$ 8.50$

THE COMPARATIVE MORPHOLOGY OF THE CAROTID BODY AND CAROTID SINUS. By William Edgar Adams, Univ. Otago Med. School, Dunedin, New Zealand. A full historical introduction dealing with the discovery of the carotid body and carotid sinus, and the evolution of our ideas concerning them and their functions, particularly in the mammals. Pub. '58, 268 pp., 97 il., Cloth, about $\$ 8.75$

THE RETICULAR FORMATION OF THE BRAIN STEM: Anatomical Aspects and Functional Correlations. By Alf Brodal, Univ. Oslo, Norway. Evaluates anatomical data in the light of the large amount of physiological information that has been brought forward in the last decade. Pub. '57, 160 pp. $(71 / 2 \times 10), 6$ il., Cloth, $\$ 3.00$

THE ALIMENTARY TRACT OF THE RUMINANT. BY David Benzie and A. T. Phillipson, Rowlett Research Inst., Bucksburn, Aberdeenshire, E. gland. Through the use of the latest equipment movements were recorded that have never before beendescribed, or described only in a tentative way. Pub. 58,74 pp. (8 1/2 x 11), 210 il., Cloth, $\$ 5.50$ 